FELIPE NÓBREGA PEREIRA

\title{
ALÉM DA ANTÁRTICA: OS LIMITES DA VIDA AO FRIO E À DESSECAÇÃO NO ÂMBITO DA ASTROBIOLOGIA
}

Tese apresentada ao Programa de Pós-Graduação Interunidades em Biotecnologia USP/Instituto Butantan e IPT, para obtenção do título de Doutor em Biotecnologia. 
FELIPE NÓBREGA PEREIRA

\section{ALÉM DA ANTÁRTICA: OS LIMITES DA VIDA AO FRIO E À DESSECAÇÃO NO ÂMBITO DA ASTROBIOLOGIA}

Tese apresentada ao Programa de Pós-Graduação Interunidades em Biotecnologia USP/Instituto Butantan e IPT, para obtenção do título de Doutor em Biotecnologia.

Área de concentração: Biotecnologia

Orientadora: Dra. Vivian Helena Pellizari

Versão original 
DADOS DE CATALOGAÇÃO NA PUBLICAÇÃO (CIP)

Serviço de Biblioteca e Informação Biomédica do

Instituto de Ciências Biomédicas da Universidade de São Paulo

(C) reprodução total

Pereira, Felipe Nóbrega.

Além da Antártica: os limites da vida ao frio e à dessecação no âmbito da astrobiologia / Felipe Nóbrega Pereira. -- São Paulo, 2015.

Orientador: Profa. Dra. Vivian Helena Pellizari.

Tese (Doutorado) - Universidade de São Paulo. Instituto de Ciências Biomédicas. Programa de Pós-Graduação Interunidades em Biotecnologia USP/IPT/Instituto Butantan. Área de concentração: Biotecnologia. Linha de pesquisa: Microbiologia ambiental.

Versão do título para o inglês: Beyond Antarctica: the limits of life to cold and desiccation in the context of astrobiology.

1. Extremófilos 2. Microbiologia polar 3. Antártica 4. Ártico 5. Astrobiologia I. Pellizari, Profa. Dra. Vivian Helena II. Universidade de São Paulo. Instituto de Ciências Biomédicas. Programa de PósGraduação Interunidades em Biotecnologia USP/IPT/Instituto Butantan III. Título. 


\section{UNIVERSIDADE DE SÃO PAULO \\ Programa de Pós-Graduação Interunidades em Biotecnologia \\ Universidade de São Paulo, Instituto Butantan, Instituto de Pesquisas Tecnológicas}

Candidato(a):

Título da Tese:

Orientador(a):
Felipe Nóbrega Pereira.

Além da Antártica: os limites da vida ao frio e á dessecação no âmbito da astrobiologia.

Profa. Dra. Vivian Helena Pellizari.

A Comissão Julgadora dos trabalhos de Defesa da Tese de Doutorado, em sessão

pública realizada a

( ) Aprovado(a) ..$/$ ..$/$. considerou

\section{( ) Reprovado(a)}

Examinador(a): Assinatura:

Nome:

Instituição:

Examinador(a): Assinatura:

Nome:

Instituição:

Examinador(a): Assinatura:

Nome:

Instituição:

Examinador(a): Assinatura:

Nome:

Instituição:

Presidente: Assinatura:

Nome:

Instituição: 


\section{CEEA-IOUSP \\ Comissão de Ética em Experimentação Animal \\ Instituto Oceanográfico - USP}

\section{PARECER SOBRE PROTOCOLO DE PESQUISA COM EXPERIMENTAÇÃO ANIMAL}

O projeto de doutorado de Felipe Nóbrega, orientado pela Profa. Dra. Vivian Helena Pellizari, estudará potencial de sobrevivência e adaptação do extremófilo Exiguobacterium antarcticum em ambientes extraterrestres simulados conforme protocolo descrito abaixo:

Especies estudadas:

Dominio: Bactéria

Filos: Proteobateria, Firmicutes, Acidobacteria, Actinobacteria, Cianobacteria, Cloroflexi

Quantidade: 27 amostras de solo (1g/amostra)

Tipo de experimento:

Extração de DNA dos microrganismos presentes em solo usando PowerSoil DNA extraction kit (MoBio Technologies) com o objetivo de determinar a estrutura da comunidade microbiana na Baia do Almirantado, Ilha Rei George, Antártica e em Axel Heiberg, Canadá. Testes de sobrevivência com isolados bacterianos em diferentes condições de estresse ambiental serão realizados através de análise da variação da viabilidade de isolados bacterianos à parâmetros físicos tais quais: pressão, temperatura, umidade e exposição à radiação.

geração de resíduo

Há geração de resíduos sólidos que serão incinerados seguindo o protocolo de descarte hospitalar

A Comissão de Ética em Experimentação Animal do IOUSP entende que o parecer não se aplica nesse estudo uma vez que abordará bactérias e não haverá experimentos. Dessa maneira o protocolo de pesquisa não infringe os princípios éticos de experimentação com animais elaborados pelo Conselho Nacional de Ética em Pesquisa (CONEP) e Colégio Brasileiro de Experimentação Animal (COBEA).

São Paulo, 03 de junho de 2014.

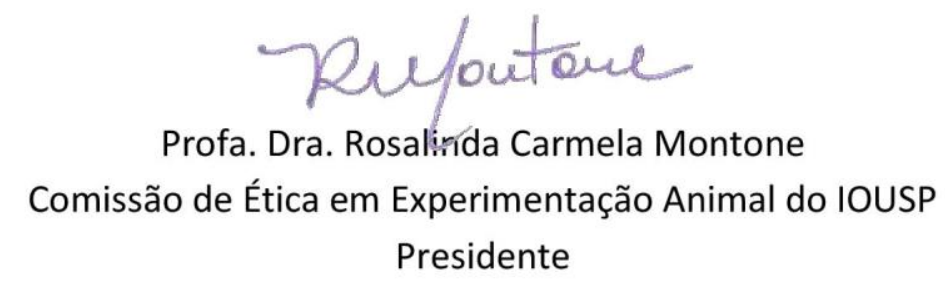

Praça do Oceanográfico, 191 - 05508-120 - São Paulo - SP

http://www.io.usp.br - Tel.: 55 - 11 - 3091-6501 - Fax: 55 - 11 - 3032-3092 
A todas as pessoas que vão de fato ler esta tese. Sim, você. Obrigado por escutar o que tenho a dizer. 


\section{AGRADECIMENTOS}

Ao povo brasileiro e ao povo paulista, sem cada um de vocês não existiriam essas palavras.

À Universidade de São Paulo, minha alma matter, pelo conhecimento adquirido ao longo de 11 anos, por todas oportunidades recebidas aqui.

À Profa. Dra. Vivian Helena Pellizari, orientadora deste trabalho de doutorado, por todas as portas que você me abriu ao longo desses anos, por todo conhecimento que me foi passado, pela amizade.

Ao Prof. Dr. Rubens Duarte, pois entrei no laboratório em meus vinte e poucos anos e durante meu amadurecimento encontrei em você um exemplo a se seguir de cientista, professor, aluno e pai.

Ao Dr. Douglas Galante e ao Prof. Dr. Fábio Rodrigues, que na alvorada do meu interesse pela astrobiologia, me ajudaram a compreender melhor esse ramo da ciência e a plantar a semente que hoje tem como fruto esse trabalho de pesquisa.

Ao Prof. Dr. Artur Silva, da Universidade Federal do Pará, por me receber durante alguns meses em seu laboratório, pela contribuição na realização dos experimentos e sugestões pertinentes.

Ao Prof. Lyle Whyte, do departamento de Ciências de Recursos Naturais, da McGill University, Canadá, pela oportunidade de realizar experimentos com amostras coletadas no Ártico durante o doutorado sanduíche, pela orientação e por partilhar comigo sua visão de ciência e ecologia microbiana.

Aos mentores dos meus projetos de pesquisa anteriores a este, que me ensinaram o que o significa ser um cientista, Profa. Dra. Sirlei Daffre, do Instituto de Ciências Biomédicas da Universidade de São Paulo e Prof. Dr. Nicholas Kotov, do Departamento de Engenharia Química da Universidade de Michigan. 
Aos amigos do LECOM: Adriana (G6), Amanda (G6), Ana, André, Célio, Cristina, Daniella, Diego (G6), Fabiana, Francieli, Juliana, Luana, Luciano (G6), Marina, Natascha (G6), Priscila, Renato, Rosa, Rubens, Simone, Vitor e Vivian. Aos parceiros das expedições antárticas: Edson Vandeira, Lukas Büdenbender e Thiago Gumiere. Aos amigos canadenses: Guillaume, Haley, Isabelle, Jackie, Jesse, Luke, Raven e Rebecca. Obrigado pela ajuda em meu amadurecimento como profissional e ser humano e pelo privilégio de poder acompanhar a jornada peculiar de cada um.

Aos meus amigos de toda uma vida, ao meu lado nos momentos de alegria e nas vicissitudes: Ana, Breno, Dani, Jovem Gui, Ju, Kim, Lennon, Lindo, Mafê, Noel, Paulo, Stela e Véros.

À CAPES pela bolsa concedida durante o doutorado, ao Programa Ciência Sem Fronteiras pela bolsa de doutorado sanduíche, ao MCTi, SECIRM, PROANTAR e à Marinha do Brasil pelo financiamento e apoio à pesquisa Antártica Brasileira.

Aos meus pais, Carmen e Manoel, por terem investido e sacrificado tanto pela minha educação, e junto com meu irmão Rafael e o Luke (sim, nosso cãozinho) por me oferecem conforto e segurança que me permitiram pensar um pouquinho além.

À fé que me moveu ao longo destes quase cinco anos. Fé de que as escolhas que tomamos agora é que erguem nosso futuro. Fé de que o destino é construído dia após dia. À fé de que toda pergunta tem sua resposta e toda resposta tem sua lógica. 
"Sou atormentado por um desejo constante pelo que é remoto. Eu amo navegar mares proibidos, desembarcar em terras bárbaras"

Herman Melville 


\section{RESUMO}

NÓBREGA PEREIRA, F. Além da Antártica: os limites da vida ao frio e à dessecação no âmbito da astrobiologia. 2015165 f. Tese (Doutorado em Biotecnologia) - Instituto de Ciências Biomédicas, Universidade de São Paulo, São Paulo, 2015.

Os limites conhecidos a vida na Terra têm se expandido ao longo dos anos, porém a vida como nós a conhecemos é estritamente dependente de água líquida. A descoberta de evidências de água em diversos corpos do sistema solar, em especial em Marte e nas luas geladas de Saturno e Júpiter, abre a possibilidade da existência de habitats fora de nosso planeta. Na Antártica e no Ártico, a vida microbiana é presente e diversificada, tendo se adaptado a condições similares às encontradas em mundos que despertam maior interesse à astrobiologia. Neste contexto, o presente estudo investigou as alterações fisiológicas do extremófilo psicrotrófico Exiguobacterium antarcticum B7 sob diferentes temperaturas, notando-se alterações significativas em diferentes áreas de seu metabolismo e fenótipo. Para tanto, foram utilizadas técnicas de eletroforese de proteínas em duas dimensões associada a espectrometria de massa, juntamente com técnicas de microscopia. E. antarcticum foi também submetida a condições físicas encontradas em Marte e no ambiente interplanetário. Em um foco mais amplo e seguindo evidências de que microorganismos psicrotróficos podem também ser resistentes a períodos prolongados de dessecação, foi investigada a presença de linhagens microbianas resistentes a baixas temperaturas e anidrobiose em solos da Antártica e permafrost do Ártico canadense. O estudo filogenético mostrou que a maioria dos isolados são bactérias gram-positivas do filo Firmicutes e bactérias gram-negativas do filo Proteobacteria, algumas cepas mostraram tolerância à dessecação comparável ao controle positivo utilizado, a bactéria Deinococcus radiodurans. Por fim, voltando-se à ecologia microbiana de solos polares permanentemente congelados, foi estudada a diversidade microbiana de permafrost, a partir da técnica de sequenciamento de alto rendimento. Os filos Actinobacteria, Chloroflexi, Proteobacteria e Acidobacteria respondem pela maioria das sequências identificadas. A estrutura da comunidade bacteriana também variou com a profundidade do solo, mas de forma distinta para cada grupo observado.

Palavras-chave: Extremófilos. Microbiologia polar. Antártica. Ártico. Astrobiologia. 


\begin{abstract}
NÓBREGA PEREIRA, F. Beyond Antarctica: the limits of life to cold and desiccation in the context of astrobiology. 2015165 f. Ph.D. thesis (Biotechnology) - Instituto de Ciências Biomédicas, Universidade de São Paulo, São Paulo, 2015.

The known limits of life on Earth has expanded over the years, being water in its liquid form the one need for its occurrence. The discovery of evidence of liquid water in various solar system bodies, especially Mars and the icy moons of Saturn and Jupiter, opens the possibility of habitats outside our planet. In Antarctica and the Arctic, microbial life is present and diverse, having adapted to low temperature and humidity conditions, similar to the worlds that arouse more interest to astrobiology. In this context, the physiological changes of the psychrotrophic extremophile Exiguobacterium antarcticum $B 7$ were investigated at different temperatures $\left(0^{\circ} \mathrm{C}\right.$ and $37^{\circ} \mathrm{C}$ ), significant changes were observed in different areas of its metabolism and phenotype. Two dimensional protein electrophoresis techniques was used for proteome analysis in conjunction with mass spectrometry for the study of bacterial proteome as well as various microscopy techniques for morphological characterization. E. antarcticum was also subjected to physical parameters found on Mars and in the interplanetary environment. In a broader focus and following evidence that psychrotrophic microorganisms may also be resistant to prolonged periods of desiccation, the presence of microbial strains resistant to cold temperatures and anhydrobiosis was investigated on samples of Antarctic soils and the Canadian Arctic permafrost. The taxonomic study of these bacteria showed that the majority of isolates are gram-positive bacteria of the phylum Firmicutes and gram-negative bacteria of the phylum Proteobacteria, some strains showed a desiccation tolerance comparable to the positive control, the bacterium Deinococcus radiodurans. At last, turning the attention to the microbial ecology of permanently frozen polar soils, it was studied the bacterial diversity of the Arctic permafrost, at different depths, with next-generation high throughput sequencing. Phyla Actinobacteria, Chloroflexi, Proteobacteria and Acidobacteria account for most of the identified sequences. The bacterial community structure also varies with depth, but differently for each group observed.
\end{abstract}

Key words: Extremophiles. Polar microbiology. Antarctica. Arctic. Astrobiology. 


\section{LISTA DE FIGURAS}

Figura 1 - Relações filogenéticas do gênero Exiguobacterium. .33

Figura 2 - Processos de fratura e subsequente formação de cunhas de gelo estratificadas por ciclos de congelamento e descongelamento repetidos

Figura 3 - Comparação entre solos poligonais do ártico canadense e Marte. .44

Figura 4 - Características de solos periglaciais em que há ocorrência de permafrost. .46

Figura 5 - Mapa de referência do gene 16S rRNA. .48

Figura 6 - Tecnologia de sequenciamento de nova geração da Illumina. .51

Figura 7 - O espectro correspondente a linha de luz associado a monocromador de grade toroidal em comparação com o fluxo solar obtida com espectro solares diários de 1999-2010. 59

Figura 8 - Espectro produzido pelo simulador solar Oriel® Sol UV-2 equipado com filtros que simulam a radiação solar presente na superfície terrestre......60

Figura 9 - Câmara de simulação de ambientes espaciais (AstroLab-USP). 61

Figura 10 - Representação das ilhas Shetland do Sul, Antártica. 63

Figura 11 - Mapa da llha Deception, Antártica, e suas zonas geotermicamente ativas. .63

Figura 12 - Mapa da área de solo exposto por recuo da geleira Baranowski, indicando os pontos de coleta. 64

Figura 13 - Mapa do Territórios do Canadá que compõem o Ártico Canadense.......65

Figura 14 - Ilustração do testemunho de solo coletado em Axel Heiberg. .66

Figura 15 - Preparo da biblioteca para sequenciamento na pelo sistema Illumina, esquematizado. 
Figura 16 - Curva de crescimento de E. Antarcticum a $0 \stackrel{\circ}{\circ}$.

Figura 17 - Curva de crescimento de E. Antarcticum a $37^{\circ} \mathrm{C}$. 74

Figura 18 - Microscopia de contraste de fase. Exiguobacterium antarcticum cultivada, a $37{ }^{\circ} \mathrm{C}$ e a $0{ }^{\circ} \mathrm{C}$, respectivamente. Barra de escala em branco correspondente a $20 \mu \mathrm{m}$. .75

Figura 19 - Microscopia de contraste de fase. Exiguobacterium antarcticum cultivada, a $37{ }^{\circ} \mathrm{C}$ e a $0{ }^{\circ} \mathrm{C}$, respectivamente. Barra de escala em branco correspondente a $5 \mu \mathrm{m}$. .75

Figura 20 - Comprimento médio de células de E. antarcticum cultivadas, a $0^{\circ} \mathrm{C}$ e a 37 ${ }^{\circ} \mathrm{C}$. 76

Figura 21 - Exiguobacterium antarcticum a $37^{\circ} \mathrm{C}$. Microscopia eletrônica de varredura ambiental. Barra de escala em branco correspondente a $5 \mu \mathrm{m}$. .77

Figura 22 - Exiguobacterium antarcticum a $0^{\circ} \mathrm{C}$. Microscopia eletrônica de varredura ambiental. Barra de escala em branco correspondente a $10 \mu \mathrm{m}$. .78

Figura 23- Espectro Raman de Exiguobacterium antarcticum 79

Figura 24 - Gel de eletroforese de 2 dimensões corados com azul de coomassie coloidal mostrando o perfil de expressão proteica de E. antarcticum em culturas de $0{ }^{\circ} \mathrm{C}$ .80

Figura 25 - Gel de eletroforese de 2 dimensões corados com azul de coomassie coloidal mostrando o perfil de expressão proteica de E. antarcticum $\mathrm{B} 7 \mathrm{em}$ culturas de $37^{\circ} \mathrm{C}$.

Figura 26 - Gel de expressão diferencial (2D-DIGE) mostrando em vermelho os spots correspondentes às proteínas expressas a $0{ }^{\circ} \mathrm{C}$ e em verde spots correspondentes às proteínas expressas a $37^{\circ} \mathrm{C}$. .82

Figura 27 - Curvas de sobrevivência de Deinococcus radiodurans, Exiguobacterium antarcticum e Planococcus halocryophilus expostas à radiação ultravioleta ambiental $(\lambda>280 \mathrm{~nm})$. .86 
Figura 28 - Curvas de sobrevivência de Exiguobacterium antarcticum e Planococcus halocryophilus mostrando os efeitos da radiação da linha de luz TGM do LNLS $(\lambda>57,47 \mathrm{~nm})$ em câmara de vácuo.

Figura 29 - Árvore filogenética enraizada de uma sequência de $700 \mathrm{pb}$ do gene $16 \mathrm{~S}$ dos isolados inferida pelo método de Neighbor Joining.

Figura 30 - Árvore filogenética baseada em sequências do gene 16S rRNA dos isolados resistentes à dessecação. A barra de escala indica 0,03 substituições por posição de nucleotídeo. Valores de bootstrap (\%), superior a 60 são mostrados nos nós.

Figura 31 - Sobrevivência dos isolados após 1, 5 e 50 dias de secagem. Após o tratamento as células foram ressuspensas em água 95

Figura 32 - Sobrevivência dos isolados após 1, 5 e 50 dias de secagem. Após o tratamento as células foram ressuspensas em meio R2B 10\% .96

Figura 33 - Simulação de gel de eletroforese de DNA das bibliotecas, criado a partir de dados de densitometria gerados pelo 2100 Bioanalyzer 98

Figura 34 - Eletroferogramas das bibliotecas de DNA das amostras de Axel-Heiberg gerados no equipamento 2100 Bioanalyzer.

Figura 35 - Distribuição dos pares de bases sequenciados quanto ao seu valor de QScore ao final dos 600 ciclos de sequenciamento 100

Figura 36 - Curvas de rarefação estimadas para as amostras de superfície (a1, a2 e a3) do testemunho de solo de Axel-Heiberg. Valor de cutoff: 0,03 102

Figura 37 - Curvas de rarefação estimadas para as amostras de interface (m1, m2 e m3) do testemunho de solo de Axel-Heiberg. Valor de cutoff: $0,03 \ldots \ldots .103$

Figura 38 - Curvas de rarefação estimadas para as amostras de permafrost ( $\mathrm{p} 1$, p2 e p3) do testemunho de solo de Axel-Heiberg. Valor de cutoff: 0,03. 103 
Figura 39 - Curvas de rarefação estimadas para as amostras de superfície (a), interface $(m)$ e permafrost $(p)$ do testemunho de solo de Axel-Heiberg.

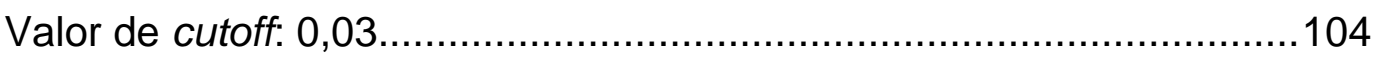

Figura 40 - Índices de riqueza Chao e Ace calculados para as amostras de Axel-

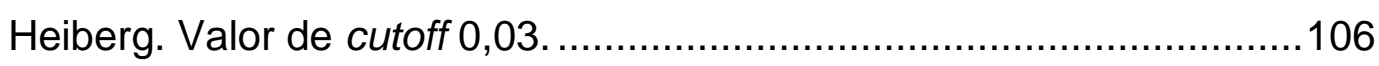

Figura 41 - Índices de riqueza Shannon e Simpson calculados para as amostras de Axel-Heiberg. Valor de cutoff 0,03. 107

Figura 42 - Diagrama de Venn representando o número de OTU compartilhadas entre as amostras da camada ativa (a1, a2 e a3), entre as amostras de solo de transição (m1, m2 3 m3) e entre amostras do permafrost (p1, p2 e p3) do testemunho de solo de Axel-Heiberg. Valor de cutoff: 0,03. 109

Figura 43 - Diagrama de Venn representando o número de OTU compartilhadas entre as amostras de camada ativa (a), interface $(m)$ e permafrost $(p)$ do testemunho de solo de Axel-Heiberg. Valor de cutoff: 0,03. 110

Figura 44 - Mapa de calor representando a similaridade de estrutura de comunidade das amostras de de Axel-Heiberg. Triplicatas de cada estrato foram analisadas individualmente. Amostras da camada ativa: a1, a2 e a3; as amostras de solo de transição: $\mathrm{m} 1, \mathrm{~m} 2$ e m3; amostras do permafrost: p1, p2 e p3. Mapa calculado com o índice de similaridade de Bray-Curtis. Valor de cutoff: 0,03 112

Figura 45 - Mapa de calor representando a similaridade de estrutura de comunidade das amostras de de Axel-Heiberg. Triplicatas de cada estrato foram analisadas individualmente. Amostras da camada ativa: a1, a2 e a3; as amostras de solo de transição: $\mathrm{m} 1, \mathrm{~m} 2$ e m3; amostras do permafrost: $\mathrm{p} 1$, p2 e p3. Mapa calculado com o índice de similaridade Theta de Yue \& Clayton. Valor de cutoff: 0,03.

Figura 46 - Mapa de calor representando a similaridade de estrutura de comunidade das amostras de de Axel-Heiberg. Triplicatas referentes ao mesmo estrato foram unidas. Camada ativa: a;Interface: $m$; permafrost: $p$. Mapa calculado com o índice de similaridade de Bray-Curtis. Valor de cutoff: 0,03. 
Figura 47 - Mapa de calor representando a similaridade de estrutura de comunidade das amostras de de Axel-Heiberg. Triplicatas referentes ao mesmo estrato foram unidas. Camada ativa: $a$; Interface: m; permafrost: $p$. Mapa calculado com o índice de similaridade Theta Yue \& Clayton. Valor de cutoff: 0,03.

Figura 48 - Abundância relativa dos Filos de Bacteria para as amostras de AxelHeiberg. 120

Figura 49 - Abundância relativa dos Filos de Bacteria no estrato da camada ativa do testemunho de solo de Axel-Heiberg. 121

Figura 50 - Abundância relativa dos Filos de Bacteria no estrato da camada de transição do testemunho de solo de Axel-Heiberg. 121

Figura 51 - Abundância relativa dos Filos de Bacteria no estrato do permafrost do testemunho de solo de Axel-Heiberg. 122

Figura 52 - Composição taxonômica ao nível de Classe dos 8 filos mais abundantes encontrados nas amostras de Axel Heiberg. 125

Figura 53 - Abundância relativa das 40 famílias mais representativas de Bacteria para as amostras de Axel-Heiberg.

Figura 54 - Ranking das 50 Famílias de Bacteria mais abundantes dentro das amostras de estrato da camada ativa do testemunho de solo de AxelHeiberg. No detalhe: Proporção de sequências que foram identificadas ao nível de Família, através da ferramenta Classifier (RDP). 128

Figura 55 - Ranking das 50 Famílias de Bacteria mais abundantes dentro das amostras de estrato de interface do testemunho de solo de Axel-Heiberg. No detalhe: Proporção de sequências que foram identificadas ao nível de Família, através da ferramenta Classifier (RDP). 129

Figura 56 - Ranking das 50 Famílias de Bacteria mais abundantes dentro das amostras de estrato de permafrost do testemunho de solo de Axel-Heiberg. 
No detalhe: Proporção de sequências que foram identificadas ao nível de Família, através da ferramenta Classifier (RDP).

Figura 57 - Abundância relativa dos 40 gêneros mais representativos de Bacteria para as amostras de Axel-Heiberg.

Figura 58 - Ranking dos 50 gêneros de Bacteria mais abundantes dentro das amostras de estrato da camada ativa do testemunho de solo de Axel-Heiberg. No detalhe: Proporção de sequências que foram identificadas ao nível de Gênero, através da ferramenta Classifier (RDP).

Figura 59 - Ranking dos 50 gêneros de Bacteria mais abundantes dentro das amostras de estrato de interface do testemunho de solo de Axel-Heiberg. No detalhe: Proporção de sequências que foram identificadas ao nível de Gênero, através da ferramenta Classifier (RDP). 134

Figura 60 - Ranking dos 50 gêneros de Bacteria mais abundantes dentro das amostras de estrato de permafrost do testemunho de solo de Axel-Heiberg. No detalhe: Proporção de sequências que foram identificadas ao nível de Gênero, através da ferramenta Classifier (RDP). .135 


\section{LISTA DE TABELAS}

Tabela 1 - Ralação das amostras de solo utilizadas para o isolamento de microorganismos adaptados à dessecação.

Tabela 2 - Proteínas expressas diferencialmente em E. antarcticum B7 identificadas por MS/MS

Tabela 3 - Número de Unidades Formadoras de Colônias por grama de solo (UFC.g-

1) isoladas de amostras de solo tratadas com clorofórmio.

Tabela 4 - Dados referentes à a eficiência da reação de sequenciamento. Valores referentes à 96 bibliotecas que foram sequenciadas conjuntamente. ...100

Tabela 5 - Lista de amostras sequenciadas, número total de contigs antes e após curadoria das sequências, total de contigs e média de contigs por amostra. 101

Tabela 6 - Números de OTUs únicas e índices de alfa-diversidade e cobertura estimados para as sequencias do perfil de solo do Ártico Canadense obtidas através de sequenciamento de nova geração. Subsample utilizado: 15838 sequências; Valor de cutoff 0,03 105

Tabela 7 - Número de sequências de Axel Heiberg classificadas em cada Filo a partir da ferramenta Classifier (RDP).

Tabela 8 - Variação da abundância relativa dos 15 filos mais abundantes em relação à profundidade do estrato de solo.

Tabela 9 - Sequências pertencentes à Famílias de micro-organismos resistentes à dessecação isoladas ao longo deste trabalho, presentes nas amostras de Axel Heiberg. 137

Tabela 10 - Sequências pertencentes à gêneros próximos aos micro-organismos resistentes à dessecação isoladas ao longo deste trabalho, presentes nas amostras de Axel Heiberg. 


\section{LISTA DE QUADROS}

Quadro 1 - Resumo dos parâmetros físicos e químicos que definem um organismo extremófilo.

Quadro 2 - Principais desafios e adaptações comuns à sobrevivência de microorganismos em baixas temperaturas.

Quadro 3 - Principais desafios e adaptações comuns à sobrevivência de microorganismos sujeitos à dessecação. 39 


\section{LISTA DE ABREVIATURAS, SIGLAS E SÍMBOLOS}

\begin{tabular}{ll}
$\boldsymbol{\lambda}$ & Comprimento de onda \\
$\mu \mathrm{m}$ & Micrômetro \\
$\mu \mathrm{g}$ & Micrograma \\
2D-DIGE & Eletroforese bidimensional em gel diferencial \\
2DE & Eletroforese bidimensional \\
ACP & Acyl Carrier Protein \\
ANOVA & Análise de variância \\
BLAST & Basic Local Alignment Search Tool \\
CCD & Charge-coupled device \\
CDS & Sequência de DNA codificadora \\
CHAPS & 3-[(3-colamidopropil)dimetilamônio]-1propanossulfato \\
CIPs & Cold induced proteins \\
cm & centímetros \\
CNPEM & Centro Nacional de Pesquisa em Energia e Materiais \\
Contigs & Sequências contíguas \\
CSP & Cold shock proteins \\
cy2 & Fluoróforo Cianina 2 (emissão na cor azul) \\
cy3 & Fluoróforo Cianina 3 (emissão na cor verde) \\
cy5 & Fluoróforo Cianina 5 (emissão na cor vermelha) \\
DNA & Ácido desoxirribonucleico \\
dNTPs & Desoxinucleotídeos \\
DGGE & Denaturing Gradient Gel Electrophoresis \\
DO600 & Densidade ótica a 600 nm \\
Dpi & Dots per inch \\
DTT & Ditiotreitol \\
EMSA & Electron mobility shift assay \\
ESI & Electronspray lonization \\
EUA & Estados Unidos da América \\
Gy & Gray (unidade) \\
h & Horas \\
H+ & Íon \\
\hline
\end{tabular}




\begin{tabular}{|c|c|}
\hline $\mathrm{H}_{2} \mathrm{O}$ & Água \\
\hline $\mathrm{HCl}$ & Ácido clorídrico \\
\hline HMP & Human Microbiome Project \\
\hline HPLC & Cromatografia líquida de alto desempenho \\
\hline HSP & Heat shock proteins \\
\hline IEF & Focagem Isoelétrica \\
\hline IPG & Immobilized $\mathrm{pH}$ gradient \\
\hline IT & Ion Trap \\
\hline IUPAC & International Union of Pure and Applied Chemistry \\
\hline $\mathrm{J} / \mathrm{m}^{-2}$ & Joules por metro quadrado \\
\hline Kb & Kilobases \\
\hline $\mathrm{KCl}$ & Cloreto de potássio \\
\hline kDa & Kilodaltons \\
\hline Km & Quilômetros \\
\hline LB & Meio de cultura Luria-Bertani \\
\hline LEA & Late embryogenesis abundant \\
\hline LECOM & Laboratório de Ecologia Microbiana (USP) \\
\hline LMW & Low molecular weight \\
\hline M & Molar \\
\hline M.A.R.S. & McGill Arctic Research Station \\
\hline $\mathbf{m} / \mathbf{v}$ & Massa por volume \\
\hline MALDI & Matrix-Assited Laser Desorption Ionization \\
\hline Mbar & Milibar \\
\hline mg & Miligrama \\
\hline $\min$ & Minuto \\
\hline mL & Mililitro \\
\hline mM & Milimolar \\
\hline $\mathrm{mm}^{2}$ & Milimetros quadrados \\
\hline $\mathbf{M n}^{2+}$ & Ílon Manganês 2+ \\
\hline MS/MS & Espectrometria de Massas em Tandem \\
\hline $\mathrm{NaCl}$ & Cloreto de sódio \\
\hline NASA & National Aeronautics and Space Administration \\
\hline NCBI & National Center for Biotechnology Information \\
\hline NL-IPG & Nonlinear immobilized $\mathrm{pH}$ gradient \\
\hline
\end{tabular}




\begin{tabular}{|c|c|}
\hline $\mathrm{O}_{2}$ & Gás Oxigênio \\
\hline $\mathrm{OH}-$ & Íon hidróxido \\
\hline ORF & Open Reading Frame \\
\hline pb & Pares de bases \\
\hline PBS & Tampão fosfato-salino \\
\hline PCR & Reação em cadeia da polimerase \\
\hline Permafrost & Solo permanentemente congelado \\
\hline pH & Potencial hidrogeniônico \\
\hline pl & Potencial Isoelétrico \\
\hline PMF & Peptide Mass Fingerprint \\
\hline PROANTAR & Programa Antártico Brasileiro \\
\hline Psi & Pound force per square inch (unidade) \\
\hline $\mathbf{R} 2 \mathbf{A}$ & Meio de cultura Ágar Reasoner's 2A \\
\hline R2B & Meio de cultura Reasoner's B \\
\hline RDP & Ribossome Database Project \\
\hline RNA & Ácido Ribonucleico \\
\hline rRNA 16S & RNA ribossomal fração $16 S$ \\
\hline $\mathrm{rpm}$ & Rotações por minuto \\
\hline rRNA & RNA ribossomal \\
\hline SECIRM & Secretaria de Comissão Interministerial para Recursos do Mar \\
\hline SDS PAGE & Eletroforese em Gel de Poliacrilamida Desnaturante \\
\hline TGM & Monocromador de grade toroidal \\
\hline TOF & Time of Flight \\
\hline TQ & Triple Quadrupole \\
\hline tRNA & RNA transportador \\
\hline TSA & Meio de cultura ágar triptona de soja \\
\hline TSB & Meio de cultura triptona de soja \\
\hline $\mathrm{U} / \mathrm{mL}$ & Unidade enzimática por mililitro \\
\hline UFC & Unidades formadoras de colônia \\
\hline UFPA & Universidade Federal do Pará \\
\hline UK & United Kingdom (Reino Unido) \\
\hline USP & Universidade de São Paulo \\
\hline UV & Radiação ultravioleta \\
\hline UVA & Radiação ultravioleta A (315 até 400 nm) \\
\hline
\end{tabular}




$\begin{array}{ll}\text { UVB } & \text { Radiação ultravioleta B }(280 \text { até } 315 \mathrm{~nm}) \\ \text { UVC } & \text { Radiação ultravioleta C }(100 \text { até } 280 \mathrm{~nm}) \\ \text { V } & \text { volts } \\ \text { v/v } & \text { Volume por colume } \\ \text { VUV } & \text { radiação ultravioleta de vácuo } \\ \text { W } & \text { Watts }\end{array}$




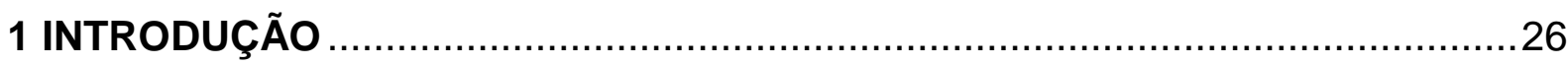

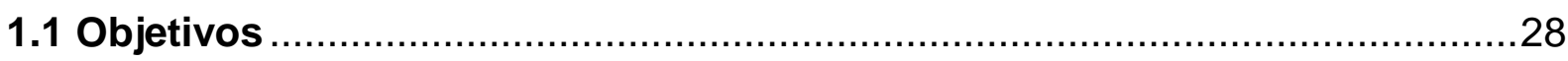

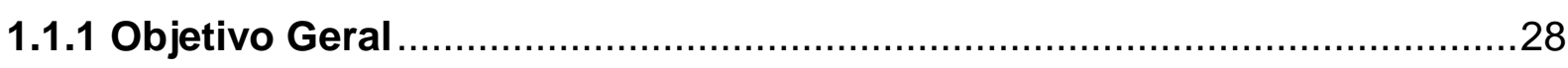

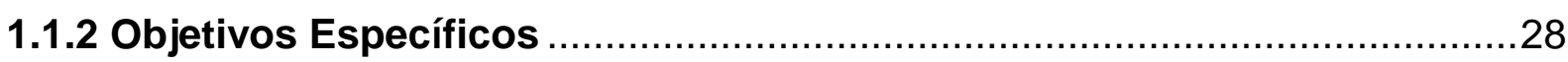

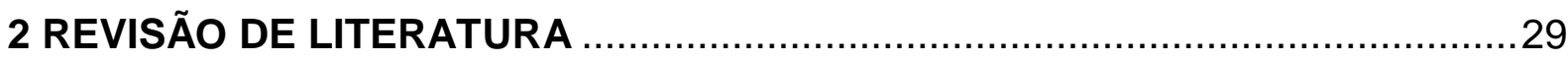

2.1 Micro-organismos extremófilos e os limites da vida na Terra ....................29

2.2 A bactéria Exiguobacterium antarcticum................................................

2.3 Micro-organismos psicrófilos, psicrotróficos e seus mecanismos de

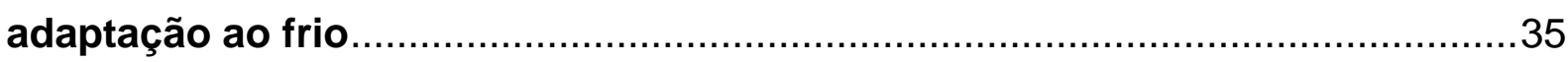

2.4 Mecanismos de adaptação a dessecação (anidrobiose) em bactérias .........38

2.5 Ambiente periglacial e permafrost na Terra e em Marte ...............................41

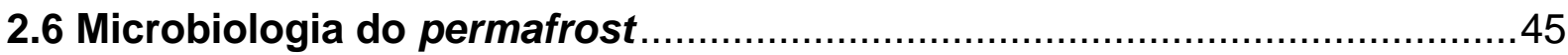

2.7 Sequenciamento de nova geração aplicado à ecologia microbiana..............47

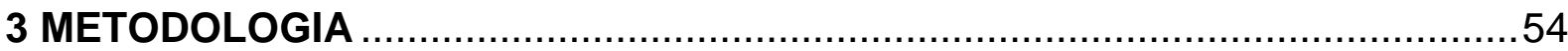

3.1 Adaptações de E. Antarcticum à variação térmica .....................................54

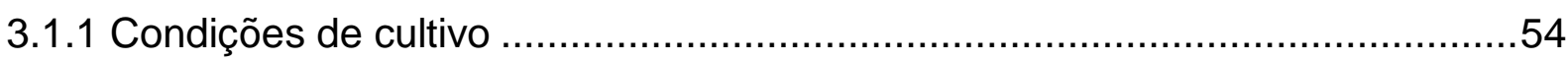

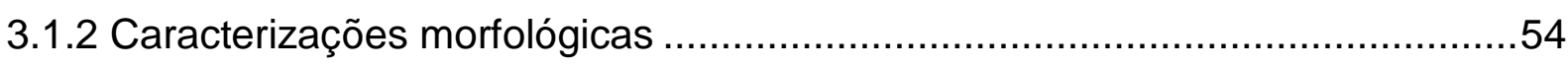

3.1.3 Extração e purificação de proteínas para proteômica …………………….........55

3.1.4 Eletroforese Bidimensional de proteínas (2D-PAGE) ....................................55

3.1.5 Eletroforese bidimensional de Fluorescência (2D-DIGE) ……......................56

3.1.6 Análise dos géis e identificação proteica por MS/MS ……..........................57

3.2 Tolerância de E. antarcticum em ambientes extraterrestres simulados ......58

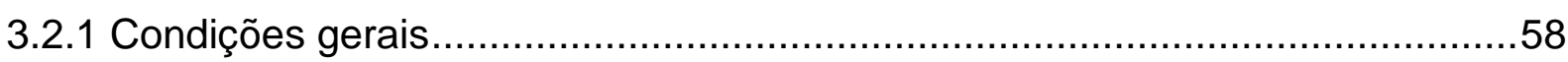

3.2.2 Simulação de radiação e vácuo do espaço interplanetário .............................58

3.2.3 Simulação de exposição à radiação solar terrestre .........................................59

3.2.4 Simulação de condições da superfície de Marte ............................................60

3.3 Prospecção de micro-organismos adaptados à anidrobiose.......................62

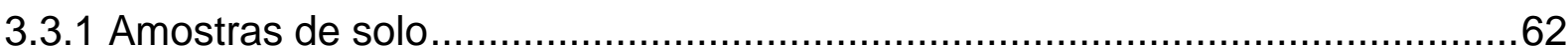

3.3.2 Isolamento de bactérias resistentes à dessecação e a baixas temperaturas ...66

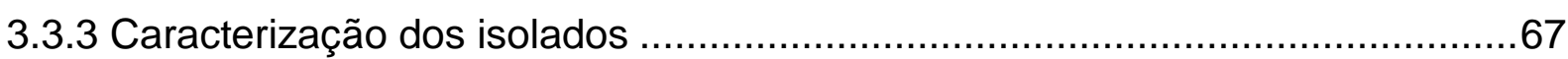

3.3.4 Análise de resistência à dessecação ........................................................68 
3.4 Diversidade microbiana em amostras de permafrost do ártico canadense. 69

3.4.1 Extração de DNA total do solo 69

3.4.2 Preparo da biblioteca de genes 16S rRNA das amostras de permafrost ........69

3.4.3 Sequenciamento da biblioteca de genes na plataforma Illumina MiSeq ..........72

3.4.4 Análise in silico da biblioteca de genes 16S rRNA ....................................72

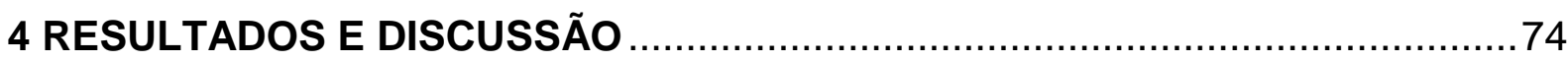

4.1 Mecanismos de adaptação térmica de Exiguobacterium antarcticum .........74

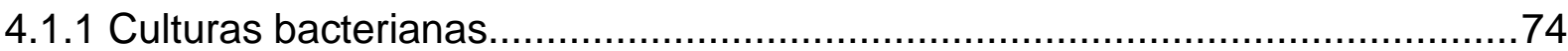

4.1.2 Proteoma diferencial de E. antarcticum ................................................. 79

4.2 Resistência de E. antarcticum B7 e P. halocryophilus OR1 aos ambientes simulados

4.2.1 Resistência à dessecação em E. Antarcticum B7 ......................................84

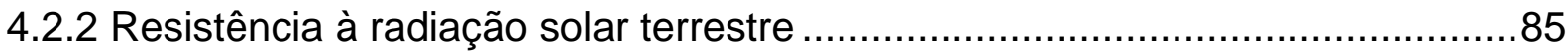

4.2.3 Resistência às condições interplanetárias e à superfície de Marte .................86

\subsection{Prospecção de psicrotróficos resistentes à dessecação em ambientes} polares

4.3.1 Isolamento e seleção de colônias .88

4.3.2 Caracterização taxonômica dos isolados .............................................90

4.3.3 Análises de resistência à dessecação..................................................94

4.4 Diversidade microbiana em amostras de permafrost do Ártico Canadense97

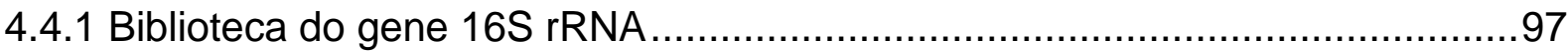

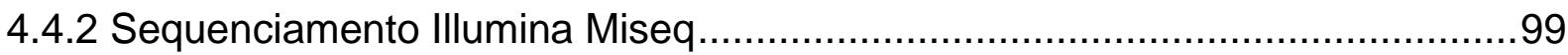

4.4.3 Estimativa de riqueza e diversidade ..................................................... 101

4.4.4 Comparação da estrutura da comunidade entre amostras de Permafrost através de métodos baseados em OTU ....................................................... 107

4.4.5 Composição da comunidade microbiana..............................................114

4.4.6 Análise comparativa entre os resultados de isolamento e sequenciamento das amostras de Axel Heiberg ............................................................................. 136

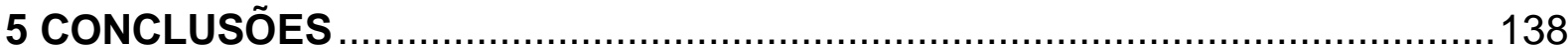

5.1 Adaptações de E. antarcticum à variação térmica ..................................138

5.2 Tolerância de E. antarcticum à parâmetros físicos de ambientes simulados

5.3 Isolamento e tolerância à dessecação de micro-organismos polares .......138

5.4 Diversidade microbiana em testemunho de solo do Ártico canadense .....139 
REFERÊNCIAS 140

APÊNDICE A - Classificação de sequências de axel heiberg (filo) 160

APÊNDICE B - Classificação de sequências de axel heiberg (família) 163

APÊNDICE C - Classificação de sequências de axel heiberg (gênero) 165 


\section{INTRODUÇÃO}

Apesar do homem ter colonizado muitos dos ambientes terrestres, microorganismos como bactérias e arqueias, são muito mais numerosos e possuem distribuição mais ampla na Terra do que qualquer outra forma de vida. Sabe-se que o planeta Terra é hoje habitado por cerca de 7 bilhões de pessoas e que na história do planeta estima-se que tenham existido ao todo 105 bilhões de seres humanos. No entanto, esse número é mil vezes menor do que os estimados 100 trilhões de microorganismos que vivem dentro do intestino humano. Em um planeta com pouco mais de 40 mil quilômetros de circunferência, a vida microbiana prospera à $4 \mathrm{~km}$ debaixo do gelo da Antártica, no lago Vostok; à $11 \mathrm{~km}$ de profundidade no local mais profundo dos oceanos, a Fossa das Marianas; e, em outra direção, à $10 \mathrm{~km}$ de altitude, já foi detectada presente no rarefeito ar atmosférico. A vida como nós conhecemos é, no entanto, limitada por diversos parâmetros físicos e químicos, a começar pela necessidade intransponível da presença de água em estado líquido (DARTNELL, 2011; STEVENSON et al., 2015). Aos micro-organismos que vivem às margens dos limites da vida se deu o nome de extremófilos, os habitantes dos ambientes extremos.

O estudo do metabolismo, mecanismos de adaptação e da diversidade de comunidades microbianas de habitats extremos nos permite compreender os limites da vida na Terra e vislumbrar os limites fora dela. A pesquisa com extremófilos em conjunto com a ciência planetária e a melhor compreensão dos ambientes extraterrestres, possibilita também um maior entendimento acerca dos limites da vida no sistema solar e além. Estes estudos integram o campo multidisciplinar conhecido como astrobiologia; que se propoe a estudar a origem, evolução, distribuição e futuro da vida no universo. Neste contexto, destaca-se o estudo de ambientes presentes nas chamadas "luas geladas" do sistema solar; classe de satélites naturais com superfície composta principalmente de gelo, porém com possibilidade de presença de água líquida subsuperficial. Acredita-se, por exemplo, que Europa, lua de Júpiter possua oceanos internos e Encélado, lua que orbita Saturno, tenha água líquida de forma localizada como bolsões de água associados à criovulcões. Em nosso planeta, os habitats polares, ártico e Antártica, delimitam a vida quanto a sua capacidade de prosperar à baixas temperaturas e sob baixa disponibilidade de água líquida. 
Na Antártica, a Estação Antártica Brasileira Comandante Ferraz (EACF) esta localizada nas proximidades da península antártica, na ilha Rei George. As pesquisas desenvolvidas pelo Brasil e outros países na região nos últimos 30 anos, resultaram em um avanço considerável no conhecimento relacionado à Antártica. A diversidade de micro-organismos na região tem sido explorada, ainda que de forma pontual. Ainda assim, apenas recentemente o Comitê Científico Internacional de Pesquisa Antártica (SCAR) tem incentivado estudos buscando explorar os limites de adaptação de microorganismos a esse ambiente e sua distribuição bi-polar (Ártico e a Antártica).

$\mathrm{O}$ isolamento de micro-organismos de habitats polares é um grande recurso para o estudo aprofundado de suas adaptações. O estudo da fisiologia destes microorganismos permite a compreensão das alterações metabólicas imprescindíveis à sobrevivência sob essas condições limítrofes. No entanto, sabe-se em microbiologia que apenas uma fração de espécies microbianas pode ser cultivada em laboratório (um número menor que 5\% para habitats terrestres), uma limitação já bastante conhecida (STALEY; KONOPKA, 1985). Recentemente, os avanços de técnicas que permitem o estudo da diversidade microbiana de forma independente de cultivo e isolamento ganhou destaque. Esses métodos se baseiam na amplificação de genes representativos de cada micro-organismo por reação de cadeia da polimerase (PCR), seguida do sequenciamento massivo de todos esses fragmentos amplificados de DNA. Desta forma, o estudo da composição filogenética de amostras de ambientes periglaciais, com auto grau de detalhamento, abre novas possibilidades de compreensão da adaptação da vida na Terra aos extremos do frio.

O objetivo deste trabalho, foi estudar a vida microbiana de regiões polares sob diferentes escopos de investigação, sendo eles: A) Fisiologia da adaptação ao frio, com a análise da expressão diferencial de proteínas de um micro-organismo antártico, Exiguobacterium antarcticum, sob cultivo em diferentes temperaturas e análise de sua sobrevivência à diferentes parâmetros físicos simulando ambientes extraterrestres. B) Resistência à condição de anidrobiose, com o isolamento e análise da capacidade de micro-organismos presentes no Ártico e na Antártica à dessecação. C) Diversidade microbiana, a partir de sequenciamento de nova geração, de três estratos de profundidade de solo permanente congelado do Ártico.

A análise do proteoma de $E$. antarcticum foi desenvolvida em colaboração com o Prof. Dr. Artur Luiz da Silva e o Prof. Dr. Rafael Azevedo Baraúna, do Laboratório de Polimorfismo de DNA da Universidade Federal do Pará (LPDNA/UFPA). Os 
estudos de simulação de ambientes extraterrestres foram realizados no Centro Nacional de Estudos em Energia e Materiais (CNPEM) e no Laboratório de Astrobiologia (AstroLab) da Universidade de São Paulo, sob os cuidados do Dr. Douglas Galante e do Prof. Dr. Fábio Rodrigues. O estudo com amostras do Ártico envolvendo a resistência à dessecação e diversidade microbiana foram realizados sob co-orientação do Prof. Dr. Lyle Whyte, vice-diretor da Rede Canadense de Astrobiologia e Professor do departamento de Ciências de Recursos Naturais, da McGill University, Canadá, com auxílio de bolsa do programa Ciência Sem Fronteiras (MCTi/CNPQ/CAPES).

\subsection{Objetivos}

\subsubsection{Objetivo Geral}

Este trabalho teve como objetivo investigar a microbiologia de ambientes polares sob diferentes escopos, compreendendo da fisiologia de um isolado ao estudo de comunidades bacterianas, visando compreender a diversidade e os mecanismos de adaptação ao frio e sua relação com o campo multidisciplinar da astrobiologia

\subsubsection{Objetivos Específicos}

O presente estudo foi dividido em quatro objetivos específicos:

a) Analisar o proteoma diferencial de Exiguobacterium antarcticum B7 quando expresso em diferentes temperaturas e, juntamente com o estudo do genoma já completo e anotado da bactéria, elucidar os mecanismos de adaptação correlacionados à essas proteínas.

b) Caracterizar o perfil de sobrevivência dos isolados Exiguobacterium antarcticum B7 e Planococcus halocryophilus OR1 quando expostos à radiação ultravioleta terrestre e condições simuladas do espaço interplanetário e da superfície do planeta Marte.

c) Isolar e caracterizar linhagens bacterianas resistentes à dessecação e ao frio intenso provenientes de amostras da Antártica e do Ártico canadense;

d) Realizar o estudo da diversidade microbiana de diferentes estratos pertencentes à testemunho de solo do Ártico (Ilha Axel Heiberg, Canadá). 


\section{REVISÃO DE LITERATURA}

\subsection{Micro-organismos extremófilos e os limites da vida na Terra}

Os limites físicos e químicos conhecidos para a existência da vida em nosso planeta tem se tornado cada vez mais amplos. Como mencionado anteriormente o único fator até o momento identificado como imprescindível para a vida como a conhecemos é a água em sua forma líquida. Um organismo é considerado um extremófilo quando vive em condições ambientais consideradas extremas, porém muitas vezes o que é "extremo" tende a ser avaliado sob ponto de vista antropocêntrico. O que é extremo para os primeiros micro-organismos que habitaram a Terra, a cerca de 3,5 bilhões de anos? Embora ainda existam muitas lacunas quanto a origem da vida na Terra, ganha força a hipótese de que a vida pode ter surgido em um ambiente redutor (anóxico), de temperaturas e pressões elevadas, nos arredores de fontes hidrotermais no fundo do oceano (KURIHARA et al., 2011; MARTIN; RUSSELL, 2003; SPANG et al., 2015). Nos primórdios da história evolutiva da vida, todos os parâmetros além destes citados podem ser considerados extremos. As variáveis ambientais comumente consideradas para categorizar um extremófilo são: temperaturas (termófilos e psicrófilos), $\mathrm{pH}$ (acidófilos e alcalinófilos), teor de sal (halófilos), altas pressões (piezófilos), radiação (radiotolerantes) e outros (Quadro 1). O estudo de poliextremófilos foi recentemente usado por Harrisson (2013) para a elaboração de mapas físico-químico dos limites da vida na Terra, chamado pelo autor de "espaço habitável" da vida (HARRISON et al., 2013). Embora os extremófilos sejam encontrados dentro dos três domínios da vida, a maioria deles pertencem aos Domínios Archaea e Bacteria (DUARTE et al., 2012; ROTHSCHILD; MANCINELLI, 2001; SECKBACH; OREN, 2007).

Os micro-organismos extremófilos adaptados às condições de frio, foco deste estudo, são classificados como psicrófilos quando a sua temperatura ótima de crescimento é igual ou menor que $15^{\circ} \mathrm{C}$ e psicrotróficos quando a sua temperatura ótima de crescimento é acima disso. Alguns organismos psicrotróficos possuem grande versatilidade quanto à temperatura em que conseguem prosperar. Exiguobacterium antarcticum tem a capacidade de se reproduzir em culturas que variam de $-3{ }^{\circ} \mathrm{C}$ até $42{ }^{\circ} \mathrm{C}$. O estudo de habitats de baixa temperatura, e em metabolismos bacterianos termicamente versáteis, é até mesmo utilizado para a 
prospecção de enzimas adaptadas ao frio que possam vir a ser úteis pela indústria em processos biotecnológicos. Até o momento o micro-organismo Planococcus halocryophilus, assim como o gênero Exiguobacterium constituinte da ordem Bacillales, é o extremófilo capaz de crescer e se dividir na menor temperatura conhecida igual $\mathrm{a}-15^{\circ} \mathrm{C}$, e se mantém metabolicamente ativo até $-25^{\circ} \mathrm{C}$ em solos permanentemente congelados do ártico canadense (MYKYTCZUK; WILHELM; WHYTE, 2012).

\begin{tabular}{|c|c|c|c|}
\hline Parâmetro & Extremófilo & Limites de crescimento & Exemplos \\
\hline \multirow{4}{*}{ Temperatura } & Hipertermófilo & $>85^{\circ} \mathrm{C}$ & Pyrolobus fumarii $\left(113{ }^{\circ} \mathrm{C}\right)$ \\
\hline & Termófilo & $45 \sim 85^{\circ} \mathrm{C}$ & Synechoccus lividis \\
\hline & Psicrófilo & $<15^{\circ} \mathrm{C}$ & Psychrobacter sp. \\
\hline & Psicrotrófico & $<15^{\circ} \mathrm{C}$ (ótimo: $\left.20^{\circ} \mathrm{C}\right)$ & E. antarcticum \\
\hline \multirow{2}{*}{$\mathrm{pH}$} & Acidófilo & $\mathrm{pH}<5$ & Cyanadium caldarium ( $\mathrm{pH} 0)$ \\
\hline & Alcalinófilo & $\mathrm{pH}>8$ & Bacillus firmus \\
\hline Salinidade & Halófilo & $2 \sim 5 \mathrm{M} \mathrm{NaCl}$ & $\begin{array}{l}\text { Família Halobacteriaceae } \\
\text { (Archaea) }\end{array}$ \\
\hline Pressão & Piezofílico & $>400 \mathrm{~atm}$ & Shewanella oneidensis \\
\hline Dessecação & Xerófilo & $\mathrm{aw}<0.8$ & Trichosporonoides nigrescens \\
\hline Radiação & Radiotolerante & Até 60 Gy/hora & Deinococcus radiodurans \\
\hline \multirow{2}{*}{ Oxigênio } & Anaeróbico & $\mathrm{Sem} \mathrm{O}$ & Methanococcus jannaschii \\
\hline & Microaerófilo & Níveis baixos de $\mathrm{O}_{2}$ & Clostridium sp. \\
\hline \multirow{2}{*}{ Nutrientes } & Oligotrófico & \multirow{2}{*}{$\begin{array}{l}\text { Crescimento em habitats } \\
\text { depletados de nutrientes }\end{array}$} & \multirow{2}{*}{ Nitrosopumilus (Archaea) } \\
\hline & Ultraoligotrófico & & \\
\hline
\end{tabular}

Quadro 1 - Resumo dos parâmetros físicos e químicos que definem um organismo extremófilo. Adaptado de (Duarte, 2012) e Rothschild (2001)

A pesquisa com extremófilos permite também a compreensão dos limites da vida dentro de nosso planeta. Muitos desses estudos são abordados dentro do campo multidisciplinar da Astrobiologia - o estudo da origem, evolução, distribuição e futuro da vida no universo - visto que a história da vida na Terra se desdobrou conjuntamente com a evolução do clima e geoquímica do planeta em si. Relacionando os limites e a distribuição da vida na Terra podemos também vislumbrar seus limites fora dela (DES MARAIS et al., 2008).

Em um trabalho de 2008, pesquisadores ligados ao NASA Ames Research Center, sugeriram temas científicos principais a serem abordados pela astrobiologia. Dentre as áreas de maior interesse destaca-se a investigação sobre a possibilidade 
da vida microbiana sobreviver e evoluir em ambientes extraterrestres (DES MARAIS et al., 2008).

Dentro do contexto de habitats considerados frios e secos, alguns estudos mostraram que o permafrost encontrado em diversos locais na Terra pode ser comparado com o solo congelado de Marte, o que nos leva a questionar a possibilidade de que micro-organismos encontrados na Terra podem ser compatíveis com o ambiente marciano. Além disso, há a possibilidade de água líquida em Marte, em aquíferos subterrâneos, e evidências de veios de água superficial enriquecida com sais de perclorato, molécula recentemente detectada pelas recentes missões espaciais a explorar esse planeta (DAVILA et al., 2010; MCEWEN et al., 2014; OJHA et al., 2015).

A sexta lua de Júpiter, Europa, também apresenta grande potencial de representar um ambiente favorável à vida. Esse satélite, pouco menor que a lua terrestre, atraía a atenção de pesquisadores por possuir uma superfície relativamente lisa quando comparada com outras luas e planetas esculpidos por inúmeras formações geológicas. Informações mais precisas acerca da natureza de Europa foram obtidas com a chegada da sonda Galileo em 1995. As evidências indicaram que Europa possui um núcleo ferroso, envolto por um manto rochoso e mais acima uma camada de $100 \mathrm{~km}$ de água. Essa camada externa de água, por sua vez, é composta por uma crosta de gelo de até $10 \mathrm{~km}$ e um oceano de água salgada logo abaixo que teria cerca de duas vezes o volume dos oceanos terrestres (ANDERSON et al., 1997). A existência de forças de maré, que são reflexo da atração gravitacional exercida por Júpiter, são a principal explicação para a existência de água líquida. Especula-se ainda que no fundo do oceano devam existir fontes hidrotermais similares às encontradas na Terra e que aqui suportam um ecossistema independente da luz solar. Estudos recentes apontam também que o oceano de Europa pode ser rico em oxigênio, originário da hidrólise da água que acontece em sua superfície, fruto da ação de raios solares (HAND; CARLSON; CHYBA, 2007). Muito ainda há o que se desvendar em nosso sistema solar, missões exploratórias além de marte são custosas e demoradas, mesmo que o desenvolvimento de futuras tecnologias possa vir a "encurtar distâncias" (SHAWYER, 2015). Ainda assim, recentemente a sonda Cassini, que vem explorando o sistema de Saturno durante uma década, detectou nuvens de vapor de água provenientes da pequena lua Enceladus, e mais além, gerou dados que sugerem que há um mar de cerca de 10 mil quilômetros cúbicos de água, 
aproximadamente o tamanho do Lake Superior (EUA-Canadá), abaixo da crosta congelada de seu polo sul (IESS et al., 2014).

Alguns trabalhos têm sido realizados envolvendo a sobrevivência de microorganismos sob condições que simulam outras regiões do sistema solar, selecionando parâmetros ambientais como a radiação ultravioleta, ciclos de congelamento e descongelamento, composição de gases presentes na atmosfera, pressão e composição química do meio. Recentemente foi demonstrado que arqueias metanogênicas do permafrost siberiano nestas condições apresentaram $90 \%$ de sobrevivência, sugerindo grande resistência por parte deste organismo às condições marcianas (MOROZOVA; MOHLMANN; WAGNER, 2007). Outros estudos procuram ainda expor os micro-organismos a condições extremas presentes na baixa órbita da Terra, com experimentos realizados na Estação Espacial Internacional ou nas camadas mais externas da atmosfera do planeta com o uso de balões (OLSSONFRANCIS; COCKELL, 2010).

O Brasil é um país atuante no campo multidisciplinar da astrobiologia e vem se destacando nas últimas décadas com um aumento no número de projetos, publicações e instalações dedicadas à pesquisa de ponta na área (RODRIGUES et al., 2012), dentro do âmbito do PROANTAR (Programa Antártico Brasileiro) e pela grande diversidade de biomas que compõe seu território (DUARTE et al., 2012).

\subsection{A bactéria Exiguobacterium antarcticum}

O gênero Exiguobacterium é formado por bactérias anaeróbias facultativas, de baixo teor de C-G, e compõe a ordem Bacillales de bactérias gram-positivas do Filo Firmicutes. Várias cepas de Exiguobacterium possuem propriedades únicas de interesse para aplicações em biotecnologia, como biorremediação, indústria e agricultura (VISHNIVETSKAYA; KATHARIOU; TIEDJE, 2009). Esse gênero possui grande variedade de cepas isoladas de ambientes diversos, de notável contraste, muitos deles considerados extremos. Exiguobacterium profundum, halotolerante e moderadamente termofílica foi isolada de fontes hidrotermais a cerca de 2.600 metros de profundidade na Dorsal do Pacífico Oriental (CRAPART et al., 2007). A linhagem também termofílica de Exiguobacterium sp. AT1b, foi isolada de uma fonte termal do parque nacional de Yellowstone, Estados Unidos (VISHNIVETSKAYA et al., 2011). A cepa TC38-2b foi encontrada em solos contaminados por mercúrio na Ucrânia 
(BOGDANOVA et al., 1998). Este gênero também possui linhagens adaptadas a ambientes periglaciais, e se mostrou presente de forma significativa em amostras de permafrost da Sibéria (RODRIGUES; TIEDJE, 2007). Na Antártica, a bactéria psicrofílica Exiguobacterium soli foi isolada de amostras de solos de morainas nos Vales Secos de McMurdo (CHATURVEDI et al., 2008).

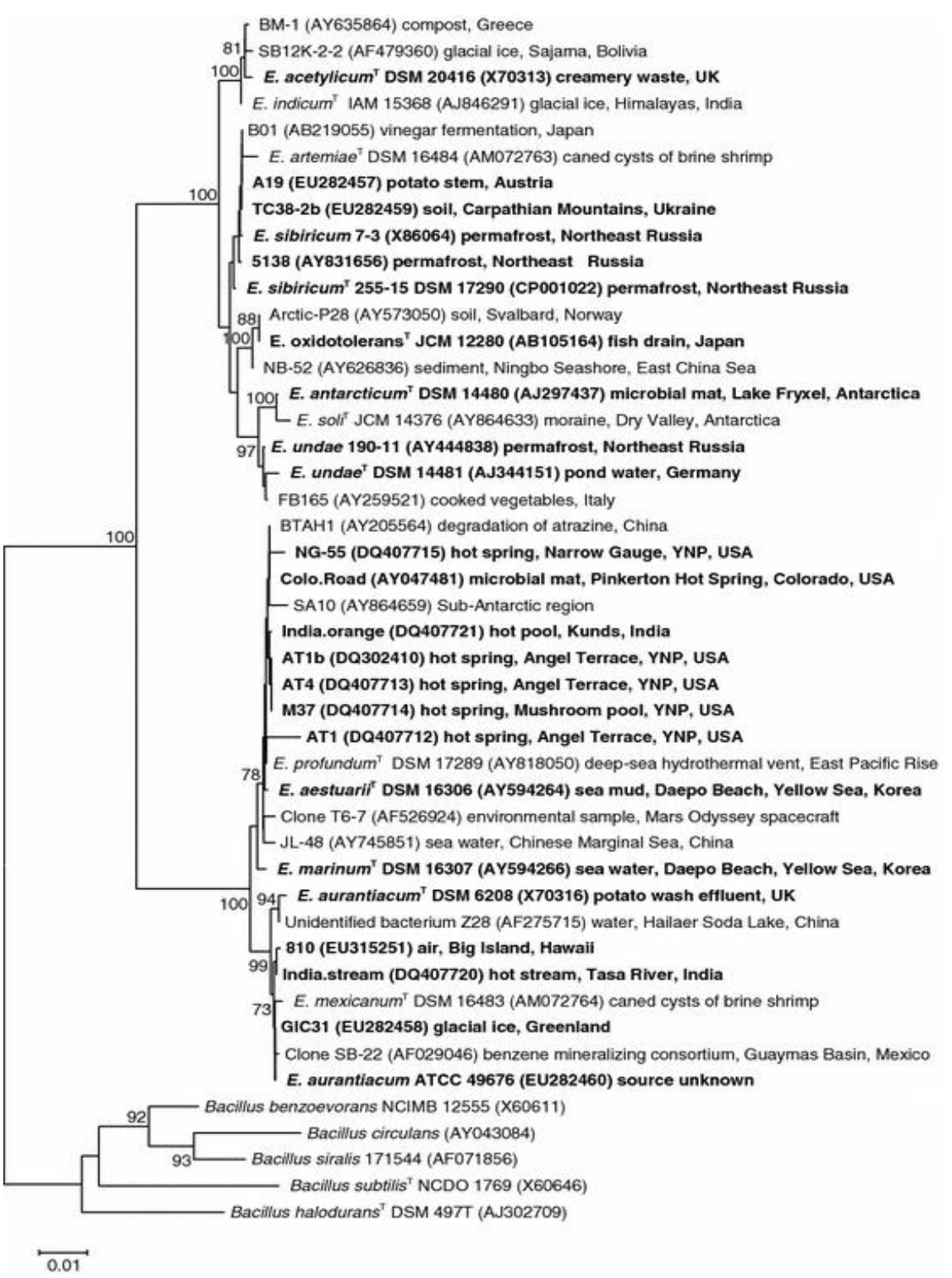

Figura 1 - Relações filogenéticas do gênero Exiguobacterium. Árvore foi produzida pelo método de neighbor-joining. Valores de bootstrap foram baseados em 1000 repetições. A barra de escala representa 0,01 alteração por posição de nucleotídeo. Fonte: Adaptado de Vishnivetskaya (2009)

Entre as bactérias de adaptadas à ambientes frios, destaca-se a bactéria psicrotrófica Exiguobacterium sibiricum 255-15 isolada de sedimentos antigos de permafrost da Sibéria norte-oriental, congelados entre 2 a 3 milhões de anos (RODRIGUES et al., 2006; VISHNIVETSKAYA et al., 2000). Além do interesse por ter sido isolada de amostras do pleistoceno, Exiguobacterium sibiricum, também possui 
grande amplitude térmica de crescimento, e tem sido estudada quanto a sua adaptação térmica. Rodrigues (2008) procurou investigar o tópico sob aspectos molecular, com o sequenciamento completo do genoma da bactéria e transcriptoma através de técnicas de Microarranjo. Os resultados revelaram poucos genes expressos diferencialmente entre $4^{\circ} \mathrm{C}$ e $28^{\circ} \mathrm{C}$. No entanto, entre $-2,5^{\circ} \mathrm{C}$ e $39^{\circ} \mathrm{C}$, os extremos da capacidade de crescimento desta bactéria, diversas adaptações fisiológicas e metabólicas associadas a respostas de estresse foram reportadas (RODRIGUES et al., 2008). Análise do proteoma simples, não-diferencial desta bactéria, porém feita a partir de lisados de células inteiras cultivados a $4{ }^{\circ} \mathrm{C}$ e $25^{\circ} \mathrm{C}$ identificou mais de 256 proteínas. Três proteínas homologas à cold shock proteins (CSPs), apesar de serem expressas a níveis semelhantes nas duas temperaturas, correspondiam a cerca de $10 \%$ do total de proteínas solúveis da célula em ambos os casos. Outras proteínas, não caracterizadas, sintetizadas apenas a $4{ }^{\circ} \mathrm{C}$ podem então fazer parte do mecanismo de adaptação que as células recorrem para se adaptar às temperaturas próximas ou abaixo de zero (QIU; KATHARIOU; LUBMAN, 2006).

A Exiguobacterium antarcticum foi isolada e descrita por Fruhling (2002), a partir de amostras de biofilme presentes no Lake Fryxell, um lago com uma cobertura permanente de gelo de 19 metros de profundidade no vale de Taylor, oeste da Antártica (LAWRENCE; HENDY, 1985). Essa linhagem foi nomeada $\mathrm{H}^{\top}{ }^{\top}$ (DSM 14480'; EMBL: AJ297437). Análises de relações filogenéticas a partir do gene rRNA $16 \mathrm{~S}$ indicam que $E$. antarcticum $\mathrm{H}^{\top}$ faça parte do mesmo agrupamento de $E$. sibiricum dentro do gênero Exiguobacterium, tendo como grupo irmão a bactéria $E$. soli, isolada da região desértica de McMurdo Dry Valleys, Antártica (Figura 1). E. antarcticum $\mathrm{H}^{\top}{ }^{\top}$ forma colônias laranjas de $2 \pm 3 \mathrm{~mm}$ em placas de Agar Triptona de Soja (TSA), depois de 2 dias a $25 \stackrel{\circ}{\circ}$. Os isolados são móveis, com flagelos peritríquios. E possuem o formato de bastonetes que variam em tamanho e forma, de $1 \pm 2$ por $3 \pm 0 \mu \mathrm{m}$ quando na fase exponencial a $0 \pm 4$ por $1 \pm 5 \mu \mathrm{m}$ na fase estacionária (BRAMBILLA et al., 2001; FRUHLING et al., 2002). Esta espécie é um modelo relevante para o estudo da capacidade microbiana por sobreviver e proliferar dentro de uma ampla variação de temperaturas, que variam de $-3{ }^{\circ} \mathrm{C}$ a $42{ }^{\circ} \mathrm{C}$, sendo considerada uma bactéria psicrotrófica com uma temperatura ótima de crescimento à $37^{\circ} \mathrm{C}$ (DALL'AGNOL et al., 2014; RODRIGUES et al., 2006).

A linhagem Exiguobacterium antarcticum B7, utilizada ao longo deste estudo, foi isolada no Laboratório de Ecologia de Micro-organismos (LECOM) da USP, no 
âmbito do Programa Antártico Brasileiro (PROANTAR), a partir de um biofilme bacteriano coletado no lago Ginger, formado por água de degelo (62 $12^{\circ} \mathrm{S}$ e $58^{\circ} 25^{\prime}$ O), nas proximidades da Estação Antártica Brasileira Comandante Ferraz. Esse isolado foi identificado com base em sua morfologia, bioquímica, coloração de Gram e análise do gene que codifica o RNA ribossomal (rRNA) 16S. Esta cepa foi sequenciada pela plataforma de sequenciamento de alto rendimento SOLiD (Life Technologies, Carlsbad, CA, Estados Unidos), e as bibliotecas genômicas formadas a partir de uma metodologia combinada de dois sequenciamentos (mate paired e fragmentos únicos) para a construção de bibliotecas genômicas. A atribuição de domínios e famílias de proteínas às open reading frames (ORFs) preditas teve anotação de curadoria manual. O genoma de E. antarcticum B7 possui tamanho de 2.815.863 pb; um conteúdo de G-C igual a 47.48\%; 2.772 coding sequences (CDSs); 9 rRNA operons; 66 tRNAs; 52 ncRNAs; e 76 pseudogenes (CARNEIRO et al., 2012).

\subsection{Micro-organismos psicrófilos, psicrotróficos e seus mecanismos de adaptação ao frio}

Temperaturas frias, na realidade, não são uma exceção no planeta Terra visto que $90 \%$ de seus oceanos possuem uma temperatura média de $5{ }^{\circ} \mathrm{C}$ ou menos do que isso (RUSSELL, 1990). O fato de que a vida microbiana é comum em lugares tão extremos da Terra como a Antártica, ampliou o escopo de ambientes em que sabemos que é possível a vida se adaptar.

Em temperaturas frias, os micro-organismos se adaptam com modificações que visam preservar a estrutura celular e manter o funcionamento das reações químicas necessárias a vida, não só ao frio, mas também ao congelamento. Em áreas em a amplitude térmica anual oscila entre o ponto de congelamento da água, comunidades microbianas devem se adaptar também à ciclos de congelamento e descongelamento;

a estações onde água líquida está disponível e em que a água está completamente congelado (ŠABACKÁ; ELSTER, 2006). Apesar de muitos mecanismos de adaptação não serem comuns a todos os seres vivos, as pressões ambientais causadas pelas baixas temperaturas são globais. Essas pressões e os mecanismos de adaptação descritos na literatura, estão sumarizados no Quadro 2 e discutidos com maior profundidade em seguida. 


\begin{tabular}{|c|c|c|}
\hline Estresse & Mecanismos de adaptação & Moléculas envolvidas \\
\hline $\begin{array}{l}\text { Diminuição da fluidez da } \\
\text { membrana celular }\end{array}$ & $\begin{array}{l}\text { Modificações estruturais na } \\
\text { membrana celular }\end{array}$ & $\begin{array}{l}\text { Síntese de ácidos graxos } \\
\text { insaturados/dessaturases }\end{array}$ \\
\hline Congelamento do citoplasma & $\begin{array}{l}\text { Redução da temperatura de } \\
\text { congelamento, estabilização de } \\
\text { macromoléculas }\end{array}$ & $\begin{array}{l}\text { Solutos intracelulares, } \\
\text { transportadores de membrana, } \\
\text { proteínas anticongelantes, trehalose }\end{array}$ \\
\hline $\begin{array}{l}\text { Redução na atividade de } \\
\text { transcrição e tradução }\end{array}$ & $\begin{array}{c}\text { Expressão positiva ou negativa de } \\
\text { genes }\end{array}$ & $\begin{array}{c}\text { Proteínas ligantes de RNA e } \\
\text { helicases, proteínas cold-shock }\end{array}$ \\
\hline $\begin{array}{c}\text { Aumento de espécies reativas de } \\
\text { oxigênio (ROS) }\end{array}$ & $\begin{array}{l}\text { Produção e acúmulo de } \\
\text { antioxidantes }\end{array}$ & $\begin{array}{l}\text { Catalases, peroxidases, } \\
\text { oxidoreductases e dissacarídeos não- } \\
\text { redutores }\end{array}$ \\
\hline $\begin{array}{l}\text { Redução da eficiência catalítica } \\
\text { de proteínas e enzimas }\end{array}$ & $\begin{array}{l}\text { Redução da temperatura ótima } \\
\text { catalítica à baixas temperaturas }\end{array}$ & $\begin{array}{c}\text { Alterações na composição de } \\
\text { proteínas; Redução de pontes de } \\
\text { hidrogênio }\end{array}$ \\
\hline
\end{tabular}

Quadro 2 - Principais desafios e adaptações comuns à sobrevivência de micro-organismos em baixas temperaturas.Fonte: Do autor.

Membrana celular: Além de alterações na maquinaria celular induzidas pelo frio, várias outras respostas a esse estresse mantém a viabilidade microbiana. Nessas condições a membrana celular passa a ser composta por uma maior quantidade de ácidos graxos insaturados e ramificados de modo que sua fluidez se mantenha mesmo sob baixas temperaturas (RODRIGUES; TIEDJE, 2008). Além disso, um grande número de bactérias da Antártica contém pigmentos carotenoides na membrana celular. Esses pigmentos podem ter um papel na fluidez da membrana, servindo como um agente mantenedor de sua fluidez em caso de quedas bruscas de temperaturas, até que ácidos graxos poli-insaturados possam ser produzidos. Esses pigmentos também parecem ter função de fotoprotetores, de moléculas ativas no processo de transferência de energia em organismos fotossintetizantes e neutralizante de moléculas oxidativas (BRITTON, 1995).

Crioproteção: Em temperaturas abaixo de zero a água pode não congelar permanecendo em um estado super-resfriado ou em misturas salinas. Em ambientes em que água se encontra completamente congelada, a capacidade de microorganismos de habitar o gelo e permafrost, mantendo seu metabolismo ativo, tem sido associada à presença de microcâmaras de água líquida. Esses micro-habitats são 
formados por agentes anticongelantes secretados pelas células, o que permite a troca de moléculas entre o meio intra e extracelulares (JOHNSON et al., 2007). A água líquida em temperaturas próximas de $0{ }^{\circ} \mathrm{C}$ sofre alterações em múltiplas propriedades como viscosidade e grau de ionização, sendo o último, crítico para o metabolismo celular visto que os íons $\mathrm{H}+\mathrm{e} \mathrm{OH}$ - são cruciais para as reações químicas que definem a vida, como por exemplo, as reações de hidrólise e óxido-redução. Essas alterações também trazem distúrbios no balanço osmótico da célula acarretando em perda de água para o meio externo. Como contrapartida foi observada a produção de solutos intracelulares que compensam esse efeito, de forma similar à resposta causada pelo aumento na concentração de sais no ambiente externo (BORRISS et al., 2003). Ambientes polares são regiões com amplitude térmica diária menos intensas quando comparada com as regiões intertropicais. No entanto, a temperatura pode variar frequentemente dentro da faixa de temperatura de congelamento da água, induzindo ciclos de congelamento e descongelamento na superfície terrestre, lagos e em habitats marinhos costeiros.

Proteínas e enzimas: A manutenção da atividade celular em baixas temperaturas, e sua resistência a choques térmicos, tem sido também relacionada a expressão de proteínas celulares induzidas pelo frio conhecidas como Cold Induced Proteins (CIPs). Dentro destas proteínas, e relacionada a aclimatação em condições de queda de temperatura foram caracterizadas as Cold Shock Proteins (CSPs).

Proteínas relacionadas a mecanismos vitais ao funcionamento celular em bactéria também parecem sofrer adaptações específicas visando a manutenção de sua atividade em temperaturas frias. Estudos sobre a estrutura e modificação de enzimas de bactérias adaptadas ao frio, quando comparadas com seus homólogos em bactérias mesofílicas e termofílicas mostraram que a flexibilidade destas enzimas é o resultado de uma combinação de diversas características, incluindo um número maior dos aminoácidos glicina e lisina e um número reduzido de resíduos de prolina e arginina em sua composição primária. Em suas estruturas secundárias e terciárias observou-se um aumento do número de cadeias laterais hidrofóbicas que são expostas ao solvente, aumento do núcleo hidrofóbico, e enfraquecimento das ligações intramoleculares (GIANESE; BOSSA; PASCARELLA, 2002).

O processo de transcrição do DNA e tradução do RNAm também é afetado em Escherichia coli crescendo em temperaturas subótimas, quando foi verificado a superexpressão de cerca de 13 proteínas contendo um domínio conservado responsável 
por se ligar ao DNA. Às proteínas possuidoras deste domínio deu-se o nome de cold shock proteins, e a deleção de seus genes codificantes inibe o crescimento da bactéria em temperaturas frias (PHADTARE, 2011). Essas proteínas, classificadas também como chaperonas, por influenciarem o dobramento de macromoléculas, assumem múltiplas funções como por exemplo a de uma helicase auxiliando no desdobramento do DNA durante a transcrição, estabilizando moléculas de RNA e auxiliando na tradução e degradação de RNAm (PHADTARE; INOUYE; SEVERINOV, 2002). Outras proteínas como a chaperona DnaK, tem a função de auxiliar no dobramento e desagregação de proteínas já traduzidas afetadas pelo frio (LELIVELT; KAWULA, 1995).

\subsection{Mecanismos de adaptação a dessecação (anidrobiose) em bactérias}

Além das baixas temperaturas, as regiões polares também têm como característica baixas taxas de umidade, sendo a Antártica a região mais extrema já que é mais fria (temperaturas que chegam a $-60^{\circ} \mathrm{C}$ ) e mais árida (taxas de umidade que vão de 10 a 1\%) (MARGESIN; MITEVA, 2011). Ainda assim, os solos congelados da Terra possuem uma biodiversidade de micro-organismos considerável, que representa as formas de vida mais antigas do planeta, e que por sua vez vem sendo cada vez mais estudada (STEVEN et al., 2006). A capacidade de sobreviver a um ambiente seco, como encontrado nos polos da Terra, leva os micro-organismos a uma condição conhecida como anidrobiose. Esse estado de estresse hídrico é caracterizado pela redução extrema do metabolismo mensurável do micro-organismo, e outras adaptações fisiológicas (Quadro3) (BILLI; POTTS, 2002).

De acordo com evidências experimentais, as bactérias gram-positivas são a maioria dos procariotos resistentes à dessecação. Recentemente, o acúmulo intracelular de $\mathrm{Mn}^{2+}$ foi proposto como um dos mecanismos principais relacionados com a proteção de proteínas contra danos oxidativos após dessecação (FREDRICKSON et al., 2008). Outra estratégia de sobrevivência observada experimentalmente é o acúmulo de dissacarídeos não redutores, tais como sacarose e trehalose (CLEGG, 2001). Estes açúcares possuem a função de proteção das macromoléculas intracelulares, formando pontes de hidrogênio normalmente formadas pela água e impedindo a desnaturação de proteínas de forma irreversível (GARCIA, 2011). 


\begin{tabular}{|c|c|c|}
\hline Estresse & Mecanismos de adaptação & Moléculas envolvidas \\
\hline $\begin{array}{l}\text { Fusão e posterior ruptura da } \\
\text { membrana celular }\end{array}$ & $\begin{array}{l}\text { Proteção da ponta hidrofílica do } \\
\text { fosfolipídio }\end{array}$ & $\begin{array}{c}\text { Síntese abundante de dissacarídeos } \\
\text { não-redutores }\end{array}$ \\
\hline $\begin{array}{l}\text { Colapso do citoplasma e } \\
\text { aglutinação de proteínas }\end{array}$ & $\begin{array}{l}\text { Vitrificação do citoplasma, } \\
\text { estabilização de macromoléculas }\end{array}$ & $\begin{array}{c}\text { Proteínas LEA, Metilamônio e } \\
\text { metilsulfônio, anidrinas, trehalose e } \\
\text { outros dissacarídeos }\end{array}$ \\
\hline Oxidação pelo ar atmosférico & Síntese de antioxidantes & $\mathrm{Mn} 2+\mathrm{e}$ peroxidases \\
\hline Danos ao DNA & Mecanismos de reparo ao DNA & Recombinases \\
\hline $\begin{array}{c}\text { Danos estruturais às proteínas } \\
\text { recém-expressas }\end{array}$ & $\begin{array}{l}\text { Correções na conformação da } \\
\text { estrutura terciária de proteínas }\end{array}$ & $\begin{array}{l}\text { Expressão de HSPs e outras } \\
\text { chaperonas }\end{array}$ \\
\hline
\end{tabular}

Quadro 3 - Principais desafios e adaptações comuns à sobrevivência de micro-organismos sujeitos à dessecação. Fonte: Do autor.

Existem também uma classe de proteínas descobertas recentemente conhecida como proteínas LEA (late embryogenesis abundant) que também estão envolvidas na tolerância à dessecação em plantas e invertebrados. LEAs não possuem estrutura definida e são bastante hidrofílicas. Essa propriedade parece permitir que elas funcionem como um escudo molecular, dificultando a agregação do acervo proteico da célula. Foi mostrado que em determinada concentração uma LEA de nematoide é capaz até mesmo de inibir a agregação do proteoma total do verme durante a dessecação in vitro (CHAKRABORTEE et al., 2007). Além disso, essa classe de proteínas também é encontrada em micro-organismos extremófilos que tiveram seu genoma sequenciado, como por exemplo bactérias do gênero Exiguobacterium, mas sua importância para a resistência à dessecação e sua distribuição dentro de comunidades microbianas ainda não foram estudas.

Proteínas comumente conhecidas como heat shock proteins (HSP), chaperonas assim como as cold shock proteins citadas anteriormente, são comumente expressas quando a célula se encontra em estresse térmico e também são super-expressas e parecem ter função relevante na tolerância à dessecação (FRANCA; PANEK; ELEUTHERIO, 2007). Outra necessidade para a sobrevivência do 
organismo é a proteção de seu DNA e implementação de mecanismos de reparo após a dessecação (TANAKA et al., 2004). Atividades enzimáticas adicionais parecem ser necessárias para a recuperação de danos, tais quais modificações covalentes na estrutura do DNA e rupturas da dupla fita, que devem ser corrigidos com a retomada do metabolismo posterior a reidratação (SHIRKEY et al., 2003).

Mais recentemente foi demonstrada a correlação entre tolerância à dessecação e resistência à radiação ionizante em Deinococcus radiodurans (SLADE; RADMAN, 2011). Esta evidência sugere a hipótese de que a tolerância à dessecação e resistência à radiação poderia ser fisiologicamente regulada por mecanismos semelhantes. Em um trabalho subsequente foi demonstrado que dos 72 genes que foram regulados positivamente durante a primeira hora depois de uma dose sub-letal de radiação ionizante, 33 desses genes também foram altamente induzidos em culturas que estavam em processo de recuperação de dessecação (TANAKA et al., 2004). Além disso, novas espécies bacterianas isoladas em câmaras de montagem de naves espaciais, esterilizadas com altas doses de radiação, mostraram também elevada tolerância à dessecação (VENKATESWARAN et al., 2003).

No ártico, pesquisadores ligados à McGill Arctic Research Station (M.A.R.S.) identificaram comunidades microbianas dentro de nascentes salinas e em solos de permafrost (solos permanentemente congelados) (NIEDERBERGER et al., 2010; POLLARD et al., 2009). Para estudar a composição de grupos de micro-organismos em um habitat e melhor compreender detalhes da fisiologia relacianada à sua resistência, os pesquisadores têm como estratégia a utilização de diversas técnicas de isolamento e cultivo que permitem o isolamento de espécies para sua melhor caracterização. No entanto, nenhuma pesquisa recente procurou entender essa diversidade usando as técnicas conjuntas de isolamento e caracterização de microorganismos psicrófilos e xerófilos (resistentes a anidrobiose), visando comparar isolados provenientes dos dois polos do planeta, o Ártico e a Antártica. Na literatura esta comparação entre os polos existe, mas não envolvendo xerófilos, e em geral empregando diferentes metodologias que podem gerar diferenças importantes no processo comparativo. 


\subsection{Ambiente periglacial e permafrost na Terra e em Marte}

Ambientes periglaciais são ambientes associados a uma ampla gama de condições de clima frio, como efeitos do congelamento e descongelamento, precipitação em forma de neve e seus efeitos de intemperismo. Esses ambientes não pertencem a geleiras, e são classificados assim independentemente da proximidade com geleiras passadas ou presentes. Estima-se que um quarto da Terra experimenta condições periglaciais em algum momento do ano (FRENCH, 2013). Em um âmbito maior, se usa o termo criosfera, parte da crosta e hidrosfera da Terra sujeitas a temperaturas abaixo de $0^{\circ} \mathrm{C}$, ou em resumo, ambientes periglaciais e glaciais. $\mathrm{O}$ uso do termo "criosfera" está mais associada aos estudos do gelo e sua distribuição no planeta, suas modificações ao longo do tempo e relação com variações climáticas (PARKINSON, 2006).

O permafrost é um elemento central do estudo da geomorfologia periglacial, definido por solo (terra ou rocha com gelo e material orgânico incluso) que permanece a ou abaixo de $0{ }^{\circ} \mathrm{C}$ durante pelo menos dois anos consecutivos (FRENCH; THORN, 2006; VAN EVERDINGEN, 1998). No Hemisfério Norte a área considerada propensa a ter permafrost está estimada em cerca de $12,8 \%$ a $17,8 \%$ da área de terra exposta. Já no hemisfério sul, o continente Antártico pode ser considerado em sua totalidade como propício à formação de permafrost, no entanto nesse caso o solo estaria muitas vezes abaixo de quilômetros de gelo sendo classificado como permafrost subglacial, protegido de flutuações sazonais de temperatura (ZHANG et al., 2000). No entanto, o solo não precisa necessariamente estar congelado para ser considerado permafrost já que o ponto de congelamento da água pode variar de acordo com parâmetros como pressão e salinidade. Da mesma forma a concentração de água não é considerada na classificação de um solo como permafrost. Sendo assim, todo solo perenemente congelado é permafrost, mas nem todo permafrost é perenemente congelado (EVERDINGEN, 1976).

O solo de regiões de permafrost por sua vez, são classificados tradicionalmente em: "camada ativa" região próxima à superfície que derrete no verão e recongela no inverno e que pode ter de alguns centímetros até dois metros de profundidade. Variações sazonais de temperatura são atenuadas com a profundidade e se limitam à esta camada. Abaixo dela se encontra o permafrost propriamente dito, camada que permanece congelada durante todo o ciclo anual (GILICHINSKY, 2002). Essa 
classificação, no entanto, muitas vezes se torna confusa já que, como citado, não necessariamente o permafrost precisa estar congelado. Mais recentemente, foi proposta uma "camada transitória" entre a parte superior do permafrost e a base da camada ativa (SHUR; HINKEL; NELSON, 2005). Essa região do solo, corresponderia então à camada que se mantém abaixo de $0^{\circ} \mathrm{C}$, assim como o permafrost, mas que pode passar por ciclos de congelamento em frequências maiores. A camada de interface sofre assim influência das duas camadas.

Hoje a presença de solos poligonais em ambientes periglaciais é reconhecida como uma marca da presença de gelo subterrâneo e permafrost, tanto na Antártica quanto no Ártico aonde essas estruturas pode chegar a até 40 metros (FRENCH, 2013; JORGENSON; SHUR; PULLMAN, 2006). Essas formações, muitas vezes são acompanhadas de cunhas de gelo subterrâneas, resultado de processos razoavelmente bem compreendidos (FORTIER; ALLARD, 2005; MACKAY, 1980; MACKAY, 1972). Polígonos acima de cunhas de gelo, em geral, possuem margens elevadas em relação ao seu centro, e são classificados como polígonos de baixo centro (Figura 3A). O processo começa durante 0 inverno, onde as baixas temperaturas causam a contração térmica do solo e induzem a formação de redes de rachaduras que se interconectam em estruturas poligonais. Esse fenômeno pode ter magnitude o suficiente para que, durante o inverno ártico, sejam relatados sons similares a trovões vindos a partir do solo acompanhados de perceptíveis tremores de terra (FRENCH; THORN, 2006). Com a chegada das estações mais quentes do ano, essas pequenas fraturas no solo são preenchidas por água líquida que se infiltra pela superfície aonde congelará com chegada do próximo inverno. Esse processo tende a se repetir novamente, as fissuras formam falhas naturais que podem ser reabertas durante as estações em que a variação de temperatura provoca novo tensionamento do solo (PLUG; WERNER, 2002). A profundidade das fraturas também tende a aumentar a cada ciclo, assim como sua largura, o que faz com que ela cresce em espessura mais em seu topo, aberto a mais tempo. Anos de re-abertura das fissuras, preenchimento por água e recongelamento transforma as fraturas em estruturas tridimensionais em forma de cunha, denominadas cunhas de gelo (Figura 2). 

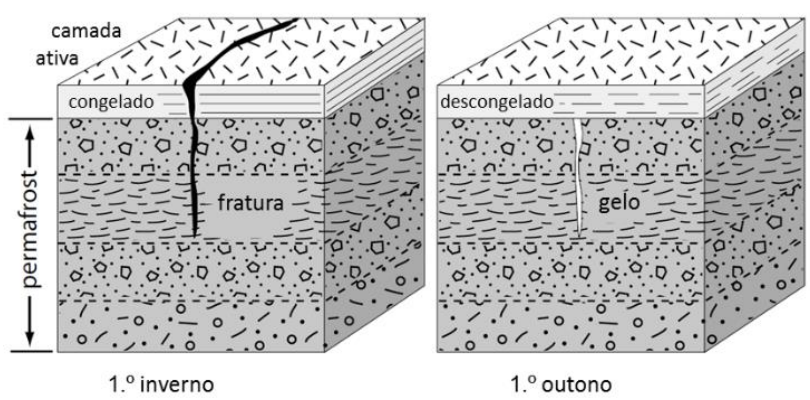

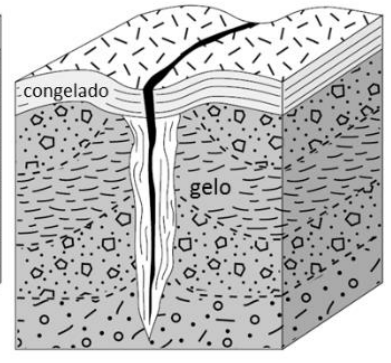

$500{ }^{\circ}$ inverno

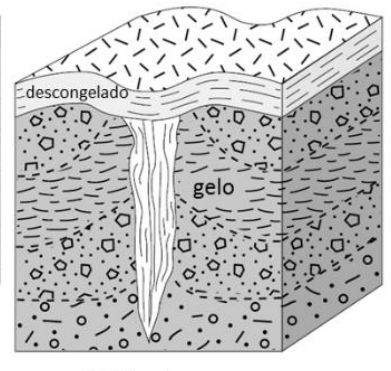

$500{ }^{\circ}$ outono

Figura 2 - Processos de fratura e subsequente formação de cunhas de gelo estratificadas por ciclos de congelamento e descongelamento repetidos; sedimentos deslocados se curvam para cima. Fonte: Adaptado de Lachenbruch (1962).

A ocorrência do mesmo padrão de solo poligonal em Marte, tem chamado a atenção da ciência há algumas décadas (Figura 3B) (PECHMANN, 1980). A classificação detalhada dessas estruturas em Marte foi possível com o lançamento de orbitadores capazes de obter imagens em alta resolução de sua superfície (MALIN; EDGETT, 2001; MCEWEN et al., 2007). Os solos poligonais descritos em Marte são bastante heterogêneos, de diferentes organizações e tamanhos que devem corresponder a diferentes processos de formação (LEVY; HEAD; MARCHANT, 2009; LEVY; MARCHANTB; HEAD, 2010; MANGOLD, 2005). Esses estudos também concluíram a correlação de solos poligonais relacionados com o gelo de permafrost com a latitude do planeta, concentrada em depósitos localizados em ambientes de circumpolares ou de alta altitude (KRESLAVSKY; HEAD, 2000; MUSTARD; COOPER; RIFKIN, 2001). Mais recentemente, o acúmulo de evidências da presença de quantidades maciças de gelo no solo superficial de Marte deu força a teoria de que solos poligonais de menor escala e de formação recente, presentes em regiões de alta latitude podem ser controlados por processos periglaciais similares aos encontrados na Terra; consequência da contração térmica, devido às variações sazonais de temperatura e ciclos de congelamento e descongelamento (BOYNTON et al., 2002). Alguns desses solos observados em Marte tem uma geometria e estrutura muito semelhante aos polígonos associados a formações de cunhas de gelo subterrâneas terrestres (MANGOLD, 2005; SEIBERT; KARGEL, 2001). Foi identificada na bacia Argyre, hemisfério sul de Marte, polígonos de pequeno porte (até 20 metros de diâmetro) de margens elevadas. podem ser consequências de processos congelamento e descongelamento associado água líquida, semelhantes aos associados na Terra à formação polígonos de baixos centro (SOARE; CONWAY; DOHM, 2014). 
A investigação in situ de ambientes periglaciais foi um dos objetivos da missão Phoenix que pousou com sucesso em Marte em 2008 (MELLON et al., 2008; MELLON et al., 2009; SMITH et al., 2008). Como esperado, Phoenix detectou uma mistura de gelo e solo logo abaixo da superfície de solo poligonal (Figura 3C). A sonda também detectou altas quantidades de sais de perclorato na composição do solo marciano. Sais de perclorato de magnésio e de sódio poderiam reduzir o ponto de congelamento da água, permitindo a presença de água líquida na superfície do planeta e formação de veios de água liquida no interior do permafrost (CHEVRIER; HANLEY; ALTHEIDE, 2009; FISCHER et al., 2014; SMITH, P. H. et al., 2009). Esse resultado reforça as evidências da presença efêmera de água líquida na superfície de Marte (KERESZTURI; RIVERA-VALENTIN, 2012; KERR, 2010).

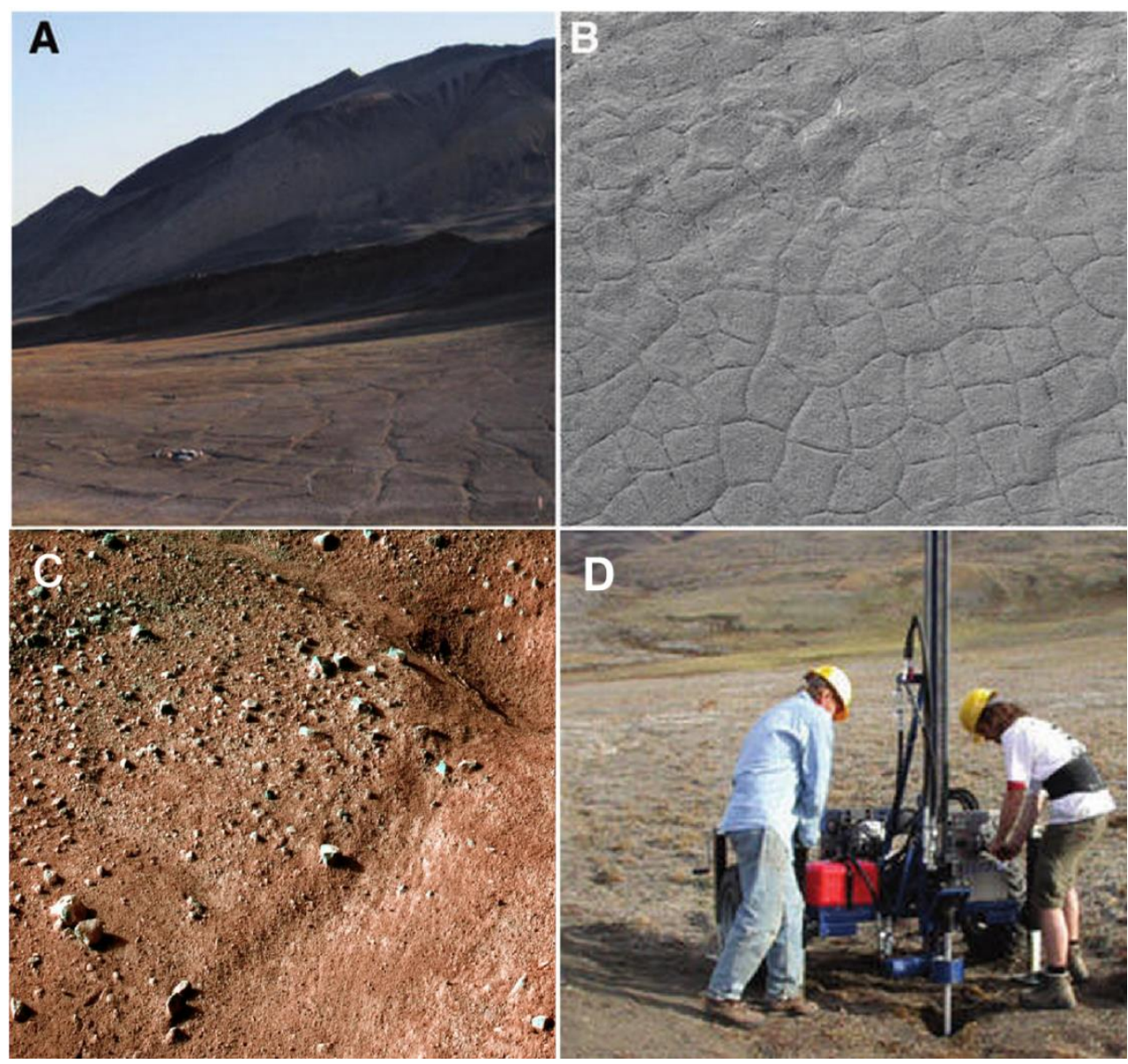

Figura 3 - Comparação entre solos poligonais do ártico canadense e Marte. Imagem A mostra vista aérea do local de amostragem de campo poligonal em Axel Heiberg (WILHELM et al., 2012); imagem $B$ polígonos registrados em imagem de satélite na região do polo sul de Marte (Mars Global Surveyor NASA); imagem C solo poligonal adjacente à sonda Phoenix Mars Lander (NASA); Imagem D descreve a perfuração de testemunho de campo de solo poligonal em Axel Heiberg (WILHELM et al., 2012). 


\subsection{Microbiologia do permafrost}

A composição mineral, teor de matéria orgânica e outras características físicoquímicas variam bastante de acordo com a localidade do permafrost, assim como sua idade de congelamento inicial. Na Antártica, aonde 99\% do continente é coberto permanentemente por gelo, estima-se que existam solos congelados há mais de 30 milhões de anos. No ártico, o permafrost mais antigo data de cerca de 5 milhões de anos (GILICHINSKY et al., 2007; MARGESIN, 2008; VIEIRA et al., 2010).

Comum às amostras de permafrost já estudadas é a presença de microorganismos, muitos deles ainda viáveis o que sugere uma capacidade de adaptação à esse ambiente (PRISCU; CHRISTNER, 2004). Além dos desafios intrínsecos às temperaturas frias e ao congelamento da água já discutidos os micro-organismos presentes neste habitat precisam lidar com a radiação natural do ambiente em escalas de tempo geológicas, e taxas de transferência de nutrientes e metabólitos extremamente baixas. Porém, apesar de pouco dinâmico, devido à baixa temperatura, o ambiente de permafrost não é estático. Mesmo em temperaturas abaixo do congelamento da água acredita-se que existam pequenos veios de água líquida que percolam as partículas de solo, muitas vezes enriquecido com sal em uma proporção maior do que o meio circundante (LOCK, 1990). Canais de algumas dezenas de nanômetros de água líquida podem servir como um meio de aquisição de nutrientes e descarte de toxinas para colônias de micro-organismos (Figura 4) (BAKERMANS et al., 2003; GILICHINSKY, 2002; JANSSON; TAS, 2014). 


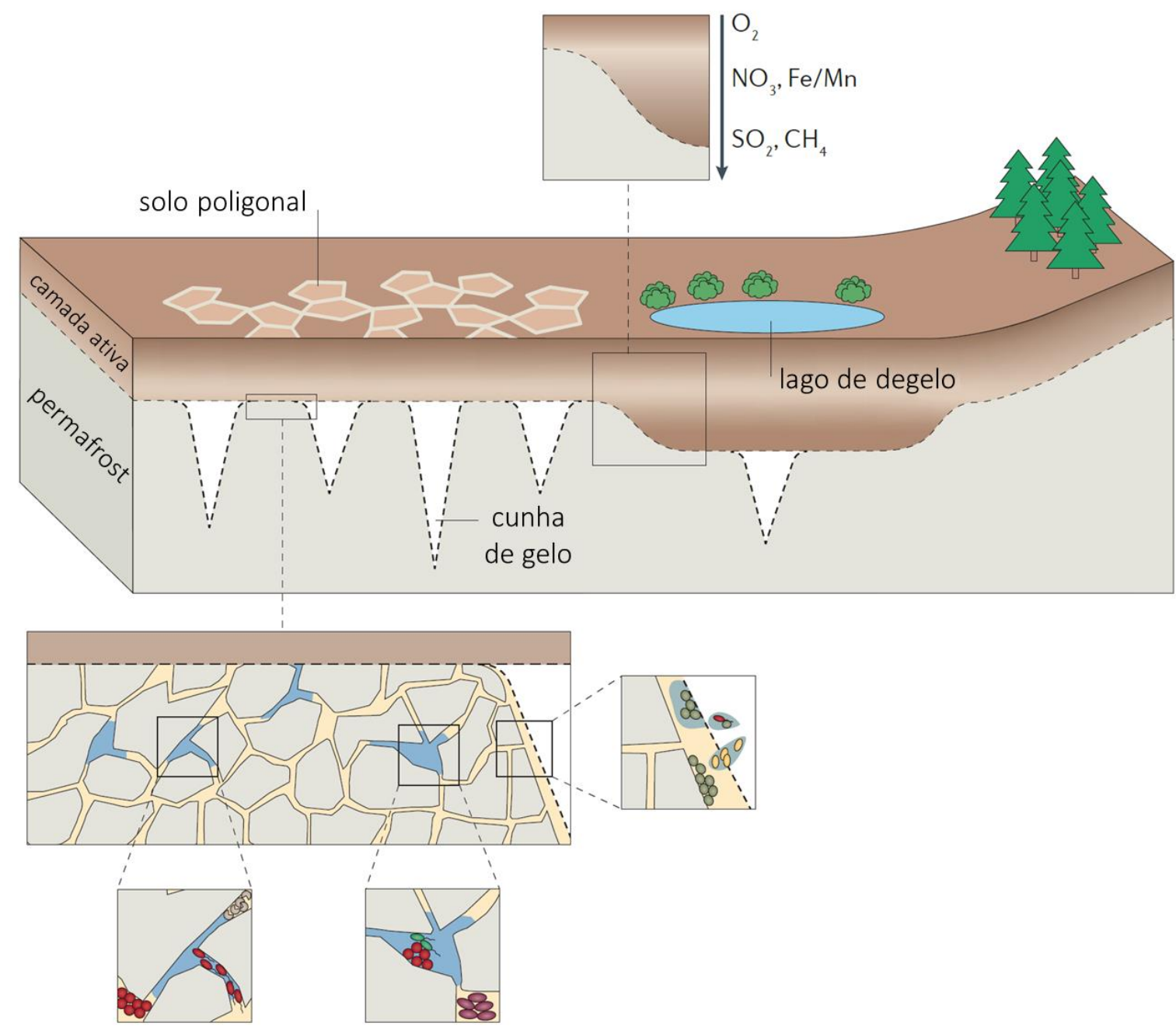

Figura 4 - Características de solos periglaciais em que há ocorrência de permafrost.O painel superior indica diferenças químicas em relação à profundidade. Os painéis inferiores mostram micro agregados individuais do solo (marrom, camada ativa; cinza, permafrost) e micro colônias de células bacterianas nos poros contendo água líquida. Fonte: Adaptado de Jansson (2014).

Os primeiros estudos com microbiologia do permafrost envolviam o isolamento e caracterização de micro-organismos. Estes trabalhos isolaram uma grande variedade de bactérias de amostras de permafrost tanto do Ártico quanto da Antártica, de organismos heterotróficos aeróbios a bactérias anaeróbicas, fixadoras de nitrogênio, enxofre-oxidante e redutoras de sulfato (STEVEN et al., 2006). A atividade microbiana foi também detectada in situ pela medição da atividade respiratória e liberação de $\mathrm{CO}_{2}$ pelo solo, assim como em laboratório medindo o fluxo de gases em sistema fechado ou com a incorporação de substratos marcados (RIVKINA et al., 2000). Essa evidencias somadas dão suporte à teoria vigente de que os ambientes de permafrost abrigam uma comunidade microbiana ativa, e não só esporos e microorganismos dormentes. 
Recentemente, com o desenvolvimento de técnicas de estudo da microbiota de forma independente de cultivo, tem sido possível vislumbrar a amplitude da diversidade de micro-organismos que habitam o permafrost. Dados de sequenciamento do gene $16 \mathrm{~S}$ rRNA de amostras de permafrost do Ártico revelaram sequências que refletem uma composição microbiana abundante em Proteobacteria, Firmicutes, Chloroflexi, Acidobacteria, Actinobacteria e Bacteroidetes, assim como como vários filos novos e não caracterizados (JANSSON; TAS, 2014; STEVEN et al., 2007; WILHELM et al., 2012; YERGEAU et al., 2010). Esses taxa desconhecidos, por sua vez, parecem ser típicos de solos de permafrost. O filo Chloroflexi, por exemplo, tem sido descrito em muitos trabalhos envolvendo permafrost, e as sequências descritas para este filo não apresentam similaridade com grupos já descritos dentro de Chloroflexi (MACKELPRANG et al., 2011; WILHELM et al., 2011). Na Ilha Rei George, Antártica, análise de permafrost por DGGE indicou também mudanças na comunidade microbiana na escala de alguns milhares de anos a partir do momento de congelamento do solo (DUARTE, 2010). Quanto a diferenças de riqueza e diversidade, em amostras de solos periglaciais do Alaska foi reportado que a diversidade microbiana em permafrost é menor do que na camada ativa nos locais estudados (TAS et al., 2014). Em Deception Island, Antártica, (BLANCO et al., 2012) mostram que a composição do permafrost do local amostrado foi predominantemente composta de Actinobacteria e Firmicutes em profundidades de 0,5 até 2 metros, e Betaproteobacteria de 3 até 4 metros; enquanto a camada ativa se mostrou mais diversificada com Acidobacteria, Actinobacteria, Proteobacteria, Bacteroidetes, Chloroflexi e os foto autotróficos Cyanobacteria como grupos dominantes.

O estudo aprofundado da ecologia e adaptações fisiológicas da vida microbiana presente no permafrost da Terra, passa a ter relevância ainda maior em um momento que a exploração do sistema solar identifica paralelos a esses ambientes, do permafrost de Marte detalhado no item anterior, às luas geladas e Plutão se mostrou indícios de atividade geológica recente.

\subsection{Sequenciamento de nova geração aplicado à ecologia microbiana}

O isolamento e cultivo de micro-organismos em laboratório é necessário para o estudo detalhado de sua fisiologia, no entanto, esse método seleciona apenas alguns membros da comunidade, estima-se que entre 1 e $5 \%$ dos micro-organismos 
podem ser cultivados em laboratório. Desta forma, o estudo de comunidades microbianas por técnicas independente do cultivo, de forma indireta, pela análise do DNA presente em amostras ambientais, se tornou uma necessidade metodológica (AMANN; LUDWIG; SCHLEIFER, 1995; TORSVIK; GOKSØYR; DAAE, 1990).

A análise do DNA presente em amostras ambientais é realizada a partir de genes específicos, que assumem função de "código de barras" para cada grupo de micro-organismos. Em Bacteria, o gene central para o estudo de sua taxonomia é o gene rRNA 16S, codificador do componente $16 \mathrm{~S}$ de seu ribossomo. Esse gene é bastante conservado dentro do reino, ao mesmo tempo em que possui regiões chamadas de "hipervariáveis", de múltiplos polimorfismos, que permitem a inferência de relações filogenéticas entre organismos (Figura 5) (WARD; WELLER; BATESON, 1990; WOESE; FOX, 1977; WOESE; KANDLER; WHEELIS, 1990). Essa metodologia depende primeiramente da amplificação de regiões específicas do gene rRNA $16 S$ por PCR. Apesar de fundamental para o estudo da ecologia de micro-organismos, é necessária cautela na análise da abundância de genes amplificados em PCRs, já que os mesmos podem não refletir de forma absoluta a abundância relativa de DNA molde. Essas diferenças podem ser fruto de afinidade diferencial do primer e número de variável de cópias do gene rRNA 16S que cada organismo pode portar (HUGHES et al., 2001).

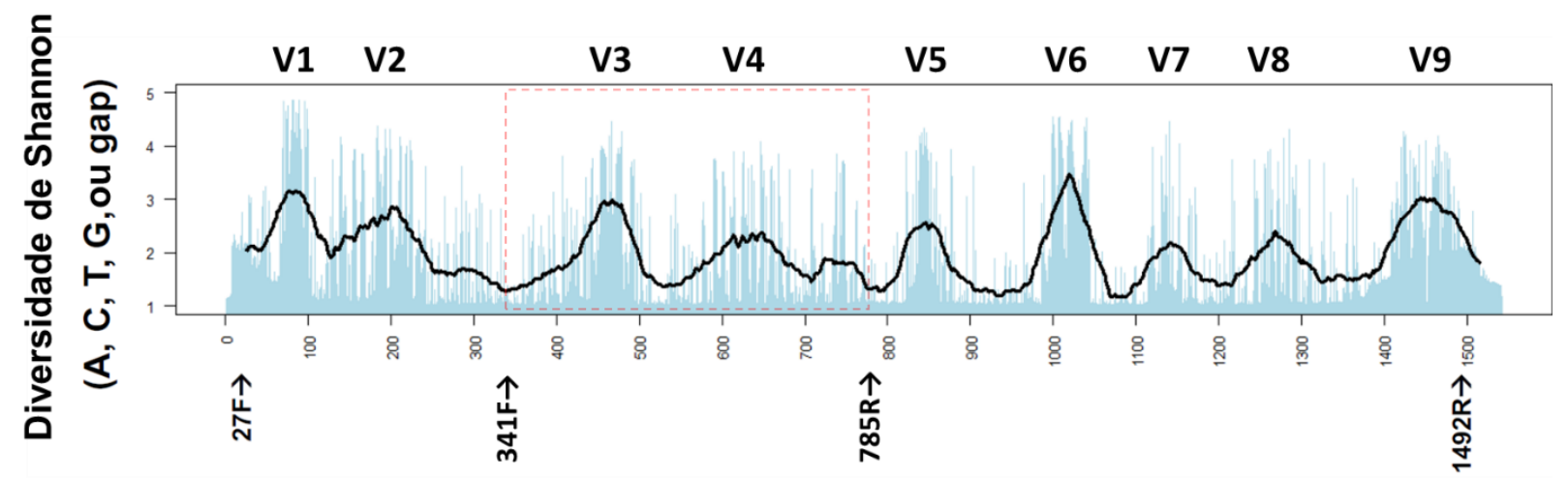

Figura 5 - Mapa de referência do gene 16S rRNA. Regiões hipervariáveis V1-V9 indicadas acima e os primers citados neste trabalho abaixo do gráfico. Diversidade de Shannon é plotada nos histogramas azuis e sua média baseada em uma janela de $50 \mathrm{pb}$ na linha negra. Diversidade foi calculada usando o banco de dados Greengenes de fevereiro de 2011. Adaptado de Chakravorty (2007) e Lundberg (2013)

Após a etapa de PCR, o estudo da comunidade microbiana por métodos moleculares pode ser divididos em dois grupos: Técnicas de fingerprinting, em que são analisadas diferentes propriedades dos amplicons permitindo a comparação 
relativística de comunidades; e técnicas de sequenciamento, que identifica a composição e o ordenamento de nucleotídeos dos amplicons e ainda possibilita a comparação dessas sequências com bancos de dados (DUARTE, 2010). Essas duas metodologias dividiram espaço no estudo de comunidades microbianas até o recente avanço das tecnologias de sequenciamento de DNA (VAN DIJK et al., 2014).

No fim da década 1970, Sanger e colaboradores desenvolveram o primeiro método amplamente difundido de sequenciamento de DNA; pela incorporação terminal de dideoxinucleotideos marcados, associada à reação em cadeia da polimerase seguida de eletroforese capilar (SANGER; NICKLEN; COULSON, 1977). Esse método se tornou sinônimo de sequenciamento de DNA pelos próximos 30 anos, com essa técnica foi realizado o primeiro sequenciamento completo do genoma humano em 2004 (CONSORTIUM, 2004). No contexto da ecologia microbiana, essa técnica possibilita o sequenciamento de até centenas de fragmentos de genes $16 \mathrm{~S}$ rRNA por estudo. Porém, esses fragmentos necessitam ser inseridos em plasmídeos que por sua vez são mantidos por células hospedeiras de Escherichia coli, para a construção de uma biblioteca de clones, um processo moroso e de alto custo.

Nos últimos anos, um conjunto de novas tecnologias de sequenciamento foram desenvolvidas, conhecidas como plataformas de sequenciamento de nova geração (next generation Sequencing - NGS) ou sequenciamento de alto rendimento (highthroughput sequencing - HTS) (SHENDURE; JI, 2008). Em comum a todas as tecnologias de NGS, destaca-se: o sequenciamento direto de amplicons (exclui a necessidade do preparo de uma biblioteca de clones); alto volume de sequências identificadas por estudo (de milhares a milhões de reações de sequenciamento são realizadas em paralelo); realização da leitura das sequências diretamente no aparelho (independente de eletroforese) (METZKER, 2010; VAN DIJK et al., 2014).

Nas tecnologias de NGS, o DNA é sequenciado em sessões, gerando sequências conhecidas pelo termo em inglês reads. O comprimento máximo das reads passou de 35-110 pb durante o lançamento dos primeiros equipamentos disponíveis comercialmente a 300-1000 pb que podem ser obtidos com as tecnologias atuais (VAN DIJK et al., 2014). Outro fator que define o potencial da reação de sequenciamento é o número de bases que é sequenciada a cada corrida, número que pode variar milhões até dezenas de bilhões de bases sequenciadas. $O$ amadurecimento dessa tecnologia também refletiu na redução de seus custos, de tal forma que o genoma humano sequenciado em 2004 por 10 milhões de dólares, pôde 
ser sequenciado em 2014 por 1000 dólares usando a plataforma Hi-Seq X (Illumina, Inc., San Diego, CA, Estados Unidos) (HAYDEN, 2014; SCHLOSS, 2008).

A escolha da plataforma de NGS depende de uma série de fatores, desde 0 tamanho do material a ser sequenciado, custo e objetivo do estudo. A primeira plataforma de sequenciamento massivo a se popularizar foi a 454 (Roche, Basileia, Suiça), também conhecido como pirossequenciamento (RONAGHI, 2001; RONAGHI et al., 1996). Mais recentemente, em um cenário em constante evolução, a plataforma Illumina se tornou líder da indústria entre as tecnologias estabelecidas de NGS, principalmente por oferecer o menor custo por base sequenciada, maior qualidade de sequências, associado a equipamentos de alto rendimento e a popularização do sequenciador de bancada MiSeq (KOZICH et al., 2013; NELSON et al., 2014).

A tecnologia de sequenciamento da lllumina funciona a partir de um processo conhecido por amplificação em fase sólida associado a sequenciamento por síntese (sequencing-by-synthesis). Essa técnica começa com a preparação de bibliotecas de amplicons (ou DNA fragmentado) ligados à adaptadores, pequenas sequências de nucleotídeos de composição específica. A biblioteca é depositada em uma superfície solida (flow cell), coberta oligonucleotídeos que vão se ligar aos adaptadores da biblioteca. Em seguida ocorre o processo de amplificação por ponte (Bridge amplification) aonde ocorrerá uma reação de amplificação controlada, denominada de cluster generation (Figura 6a). De forma similar à PCR, a bridge amplification se dá por ciclos de denaturação e extensão que resultam na amplificação de dos fragmentos de DNA que ficaram preso à flow cell, gerando de milhões à bilhões de clusters clonais por toda a flow cell. A tecnologia de sequenciamento por síntese usa nucleotídeos terminadores, que impedem a extensão do fragmento de DNA, mas de forma reversível. Cada um dos 4 tipos de nucleotídeos é marcado com uma cor única, após sua incorporação na fita de DNA pela polimerase, o marcador fluorescente é identificado por excitação a laser e identificado por uma câmera de CCD e em seguida clivado enzimaticamente, revertendo a condição terminadora do último nucleotídeo incorporado, para dar continuidade a um novo ciclo de extensão. A identificação das bases é feita a cada etapa da síntese da fita de DNA (figura 6b) (BENTLEY et al., 2008; FEDURCO et al., 2006; TURCATTI et al., 2008). 
a) Amplificação em fase sólida

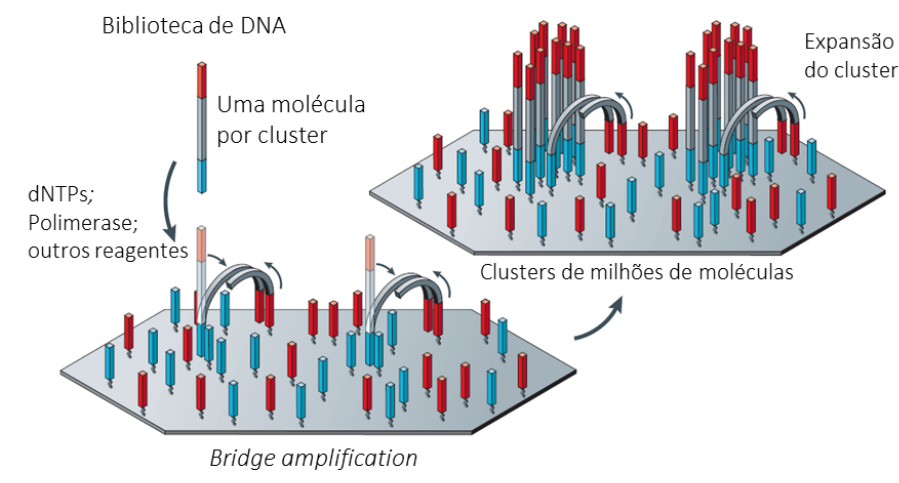

b) Sequencing-by-synthesis

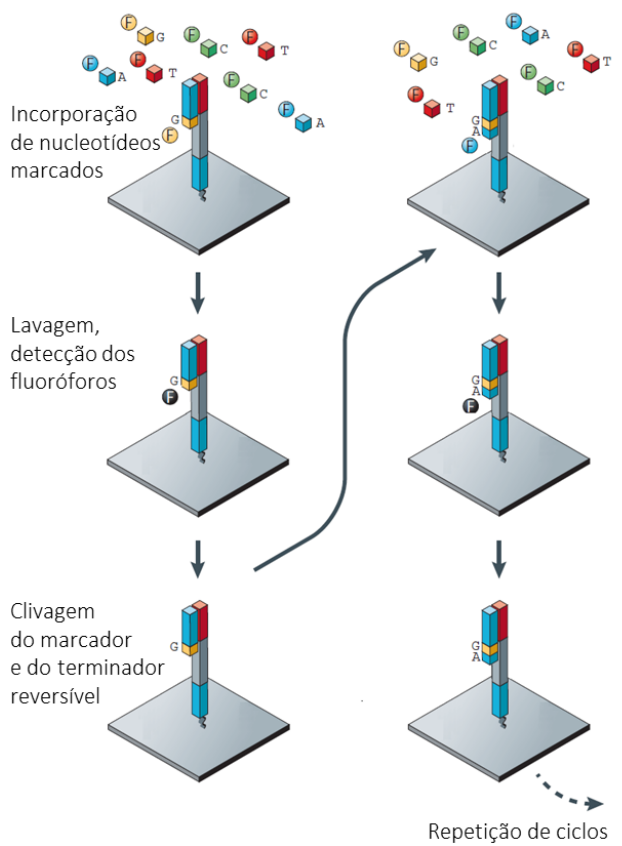

Figura 6 - Tecnologia de sequenciamento de nova geração da Illumina. a) Biblioteca de DNA é imobilizada na superfície da flow-cell, aonde ocorre amplificação por ponte gerando a formação de clusters. b) Leitura das bases por sequenciamento por síntese, a cada ciclo de amplificação a base incorporada é detectada por uma CCD. Milhões de clusters são mapeados simultaneamente. Adaptado de Metzker (2010).

A plataforma Illumina também pode se beneficiar da geração de sequências paired-end em que cada amplicon é sequenciado duas vezes, a partir da ponta 3' e da 5' da molécula de DNA. Desde que as reads paired-end se sobreponham, a geração de sequências contíguas (contigs) resulta em sequências finais de tamanho maior que o das reads individuais ao mesmo tempo em que se reduz os erros intrínsecos do processo de sequenciamento (WERNER et al., 2012).

Em termos práticos, a democratização do sequenciamento de nova geração revolucionou o campo da ecologia microbiana. Possibilitando estudos que observam a estrutura da comunidade, sua diversidade metabólica e funcional, assim como variações espaciais e temporais em uma resolução inédita (LOGARES et al., 2012). Porém junto com a abertura de novas oportunidades, surgiram novos desafios. $O$ processamento da quantidade massiva de dados gerados é o maior empecilho para a interpretação dos resultados gerados, já que a tecnologia de sequenciamento avançou em uma velocidade muito maior do que o poder computacional (STEIN, 2010).

Um exemplo da ordem de ambição que projetos de ecologia microbiana podem tomar é o Projeto Microbioma Humano (Human Microbiome Project - HMP), fundando 
pelo NIH (National Institutes of Health - EUA) que tem como objetivo permitir o estudo das comunidades microbianas que habitam diferentes partes do corpo humano, assim como o papel por eles desempenhado na saúde humana e em suas doenças (TURNBAUGH et al., 2007). Até 2012, o HMP já havia produzido mais de 35 bilhões de reads de 16S rRNA a partir de 690 amostras tomadas de 15 locais do corpo de 300 indivíduos dos Estados Unidos, produzindo 2,3 terabytes de dados (CHO; BLASER, 2012; CONSORTIUM, 2012).

A análise dos dados gerados não é trivial e depende do processamento das sequências geradas com diversas abordagens em bioinformática. A análise dos dados gerados não é trivial, seu uso depende do foco do estudo em questão e precisa levar em conta a possibilidade da introdução de vieses e artefatos diversos. Entre os pacotes de software que incorporam uma miríade de algoritmos para a geração de resultados no âmbito da ecologia microbiana se destacam o projeto MOTHUR (SCHLOSS et al., 2009) e QIIME (CAPORASO et al., 2010).

De maneira simplificada, o processamento de sequências começa com a geração de sequências contíguas (no caso de sequenciamentos paired-end) juntamente com mitigação de erros intrínsecos do processo de sequenciamento e remoção de sequencias quimeras. Como o delineamento de espécies em microorganismos se provou ser uma tarefa muito desafiadora é comum o agrupamento das sequências dentro de um valor pré-determinado de similaridade, que agrupa as sequências dentro de Unidades Taxonômicas Operacionais (Operational Taxonomic Units - OTU) (BLAXTER et al., 2005; DOOLITTLE; ZHAXYBAYEVA, 2009). Por fim, é feita a atribuição taxonômica das sequências curadas através da comparação de sua similaridade com sequências taxonomicamente classificadas, utilizando algoritmos classificadores. Diversos bancos de dados continuamente coletam e organizam sequências de DNA ribossomal como o projeto SILVA (PRUESSE et al., 2007), RDP (COLE et al., 2007) e Greengenes (DESANTIS et al., 2006).

Com a revolução gerada pelas tecnologias de sequenciamento há uma tendência de que os estudos em ecologia microbiana demandem maior dedicação no processamento em bioinformática dos dados gerados do que na geração das sequências em si. É também provável que grande parte dos sequenciamentos sejam feitos de maneira terceirizada, por centros ligados às universidades ou empresas privadas. Essa revolução também acompanha a necessidade de uma enorme 
capacidade de processamento de dados, que deve ser suprida por clusters de computadores ou serviços de computação em nuvem. 


\section{METODOLOGIA}

\subsection{Adaptações de E. Antarcticum $\mathrm{B} 7$ à variação térmica}

\subsubsection{Condições de cultivo}

A partir da cultura estoque de $E$. antarcticum linhagem $\mathrm{B} 7$ mantido a $-80^{\circ} \mathrm{C}$ e glicerol $50 \%$, o isolado foi plaqueado em TSA à $37^{\circ} \mathrm{C}$ por 18 horas.

Pré-inóculos foram preparados, transferindo uma colônia isolada para um Erlenmeyer contendo $100 \mathrm{~mL}$ de meio TSB, e crescidas a $37{ }^{\circ} \mathrm{C}$, sob agitação constante, até que uma densidade óptica de 1,0 a $600 \mathrm{~nm}$ (DO600) fosse atingida. Em seguida, os pré-inóculos foram utilizados para inocular $1000 \mathrm{~mL}$ de TSB, até uma densidade óptica de 0,045 (DO600). Os cultivos foram então incubados à $37^{\circ} \mathrm{C}$ e a 0 ${ }^{\circ} \mathrm{C}$, sob agitação constante, até chegar na fase de crescimento LOG $(0,45<\mathrm{DO} 600$ $<0,5)$. As culturas foram realizadas em triplicatas e a densidade ótica foi medida de hora em hora para os cultivos à $37^{\circ} \mathrm{C}$ e a cada 24 horas para o cultivo à $0^{\circ} \mathrm{C}$. Leitura da densidade ótica das culturas foram realizadas no espectrofotômetro Novaspec II (Pharmacia Biotech, Piscataway, NJ, Estados Unidos).

\subsubsection{Caracterizações morfológicas}

A captura de imagens por microscopia eletrônica foi realizada com o microscópio eletrônico de varredura ambiental FESEM (FEI Quanta ${ }^{\text {TM }} 650$ FEG, FEI, Hillsboro, OR, Estados Unidos), no Laboratório Nacional de Nanotecnologia (LNNano) do Centro Nacional de Pesquisa em Energia e Materiais (CNPEM). Células cultivadas como descrito no item anterior foram centrifugadas à $800 \mathrm{~g}$ e concentradas 10 vezes em tampão PBS 10\%. A captura de imagens por microscopia ótica de contraste de fase foi realizada com o microscópio Olympus BX-51® (Shinjuku, Tokyo, Japan). Análise do comprimento médio das células, e seu desvio padrão, foi obtida a partir da contagem de pouco menos de 10 mil células com o software Image-Pro® (Olympus).

Os espectros Raman foram obtidos com o objetivo de detectar possíveis pigmentos presentes em células de Exigobacterium antarcticum. Foi utilizado o equipamento Renishaw (Renishaw PLC, Wotton-under-Edge, Reino Unido) inVia micro-Raman Spectrometer com a linha de laser HeNe (633 nm), objetiva 209 e 
detector CCD. Foram realizados espectros Raman de colônias de E. antarcticum após 24 horas de crescimento à temperatura ambiente, em placas de meio de cultura TSA, depositando uma colônia em uma lâmina de vidro, sem preparações adicionais.

\subsubsection{Extração e purificação de proteínas para proteômica}

Conforme descrito no item 3.1.1, após atingir a densidade ótica desejada, as culturas foram centrifugadas a $8000 \mathrm{~g}$, por $30 \mathrm{~min}$, a $4{ }^{\circ} \mathrm{C}$. O sobrenadante foi descartado e o sedimento de células foi lavado três vezes com $50 \mathrm{mM}$ Tris- $\mathrm{HCl}$ pH 7,5 e depois ressuspenso em tampão de lise na proporção 1:2, constituído de ureia 42\%, tioureia 15\%, CHAPS 4\%, Tris-HCl 12,5 mM pH 7,5, DTT 1,5\%, DNase $146 \mathrm{U} / \mathrm{mL}$ e coquetel de inibidores de proteases (GE Healthcare, Little Chalfont, Buckinghamshire, Reino Unido).

A suspensão foi mantida no gelo e as bactérias rompidas por uma prensa francesa (Thermo Fischer Scientific, Waltham, MA, Estados Unidos) operando a 23500 psi, utilizando a célula 40K standard. O processo foi repetido três vezes. $\mathrm{O}$ lisado celular foi centrifugado por $40 \mathrm{~min}$, a $8000 \mathrm{~g}$, a $4{ }^{\circ} \mathrm{C}$. O sobrenadante contendo o extrato bruto de proteínas solúveis, foi coletado e submetido à ultracentrifugação a $100.000 \mathrm{~g}$ por 90 minutos, a $4^{\circ} \mathrm{C}$. Por fim, o novo sobrenadante contendo as proteínas solúveis foi coletado e armazenado $\mathrm{a}-80^{\circ} \mathrm{C}$. Quantificação de proteínas foi realizada com o 2D Quant kit (GE Healthcare), desenvolvido para amostras proteicas complexas, seguindo orientações do fabricante.

\subsubsection{Eletroforese Bidimensional de proteínas (2D-PAGE)}

As proteínas solúveis foram analisadas por eletroforese em gel bidimensional, abreviado como 2-DE, em que a mistura de proteínas são separadas por duas de suas propriedades, peso molecular e ponto isoelétrico, em duas dimensões de um gel de poliacrilamida (OFARRELL, 1975).

Uma massa do extrato correspondente a $600 \mu \mathrm{g}$ de proteína foi precipitada com metanol/clorofórmio. Posteriormente, as proteínas foram dissolvidas em $340 \mathrm{~mL}$ de solução de reidratação, contendo ureia $7 \mathrm{M}$, tio ureia $2 \mathrm{M}$, CHAPS 2\%, solução de anfólitos (pH 3-11) 1\%, DTT 50 mM e azul de bromofenol 0,002\%. Essa solução foi usada para reidratar as tiras de gel para IEF $(\mathrm{pH} 3-11,18 \mathrm{~cm}$, GE Healthcare) durante 
$16 \mathrm{~h}$, segundo protocolo da GE Healthcare®. A IEF foi feita na cuba Ettan TM IPGphor I/ (GE-Healthcare) com a seguinte programação de cinco passos: $100 \mathrm{~V}$ por $1 \mathrm{~h}, 500$ $\mathrm{V}$ por $2 \mathrm{~h}$, gradiente até $1.000 \mathrm{~V}$ por $2 \mathrm{~h}$, gradiente a $10.000 \mathrm{~V}$ por 3 horas e por fim $10.000 \mathrm{~V}$ até $60 \mathrm{kVh}$ com uma corrente constante de $75 \mu \mathrm{A} /$ strip. Após a IEF, as tiras de gel foram equilibradas com tampão de equilíbrio (ureia $6 \mathrm{M}$, Tris- $\mathrm{HCl} 75 \mathrm{mM} \mathrm{pH}$ 8,8, glicerol 30\%, SDS 2\%, azul de bromofenol 0,002\%) em duas etapas de 15 minutos a temperatura ambiente, uma na presença de DTT 64,8 mM e outra na presença de iodoacetamida 135,2 mM. Cada tira equilibrada com SDS foi, então, transferida para o topo de um gel de poliacrilamida homogêneo 15 e selada com 0,5\% agarose em tampão de corrida (25 mM Tris, $192 \mathrm{mM}$ glicina, 0,1\% SDS). O padrão de massa molecular LMW-SDS Marker Kit (GE Healthcare) foi também aplicado no topo do gel em um papel de filtro. A SDS-PAGE foi feita no sistema vertical Ettan ${ }^{\mathrm{TM}}$ DALTsix (GEHealthcare) a $15^{\circ} \mathrm{C}$. A eletroforese transcorreu com potência inicial de $5 \mathrm{~W}$ por gel durante $30 \mathrm{~min}$, e depois $17 \mathrm{~W}$ por gel, até o corante azul de bromofenol alcançar o fim do gel. As proteínas foram coradas com azul de Coomassie coloidal (sulfato de amônio 0,6 M, ácido fosfórico 0,8\%, Coomassie Blue G-250 0,08\%, metanol 20\%). Os géis foram digitalizados usando o ImageScanner (GE Healthcare), com resolução de $300 \mathrm{dpi}$, e as imagens foram analisadas com o software ImageMaster 2D Platinum 7.0 (GE Healthcare).

\subsubsection{Eletroforese bidimensional de Fluorescência (2D-DIGE)}

As proteínas foram analisadas também por eletroforese bidimensional de fluorescência diferencial, que possibilita comparar as proteínas em um gel de duas dimensões expressas em condições distintas (UNLU; MORGAN; MINDEN, 1997). Para tanto, $120 \mu \mathrm{g}$ de proteína foi precipitado com metanol/clorofórmio e ressuspendido para uma concentração final de $3 \mu \mathrm{g} / \mu \mathrm{L}$ em tampão de amostra (ureia 7M, tioureia $2 \mathrm{M}$, CHAPS 4\%, Tris- $\mathrm{HCl} 30 \mathrm{mM} \mathrm{pH} \mathrm{8,5).} 54 \mu \mathrm{g}$ de proteínas foram, então marcadas diferencialmente com adição de 400 pmol dos fluoróforos Cy3 (cultivo a $0{ }^{\circ} \mathrm{C}$ ) e Cy5 (cultivo a $37^{\circ} \mathrm{C}$ ), de acordo com as instruções do fabricante (GE Healthcare). A reação ocorreu por 30 minutos em gelo, na ausência de luz. Enquanto, fluoróforos Cy3 e Cy5 foram específicos para cada condição de cultivo foi utilizado o fluoróforo Cy2 como padrão interno que marca uma amostra contendo uma mistura de proteínas expressas por $E$. antarcticum à $0{ }^{\circ} \mathrm{C}$ e $37^{\circ} \mathrm{C}$, seguindo o mesmo 
protocolo de marcação já descrito. A reação de marcação foi interrompida com a adição de $1 \mu \mathrm{L}$ de solução de L-lisina $10 \mathrm{mM}$ por 10 minutos em gelo e no escuro. As amostras pareadas e diferencialmente marcadas, foram misturadas e diluídas com tampão de reidratação e submetidas a eletroforese bidimensional conforme descrito no item 3.1.4 com todas as etapas realizadas no escuro.

\subsubsection{Análise dos géis e identificação proteica por MS/MS}

As imagens dos géis foram adquiridas pelo digitalizador Ettan ${ }^{\text {TM }}$ DIGE Imager (GE Healthcare). A exposição foi ajustada de modo a não saturar o sinal e a resolução foi de $100 \mathrm{~mm}$. A análise das imagens foi feita com o software Image Master $2 D$ Platinum 7.0 (GE Healthcare), os spots de cada gel foram detectados automaticamente. Cada spot foi normalizado com o volume total e comparado entre as replicatas. Foram considerados spots diferenciais aqueles com diferença de pelo menos \pm 2 vezes em seu volume relativo. Somente spots com diferença significativa segundo análise estatística ANOVA entre as replicatas $(P<0,05)$ foram considerados diferencialmente expressos. As proteínas expressas diferencialmente foram recortadas do gel com o auxílio do equipamento Ettan ${ }^{\mathrm{TM}}$ Spot Picker, desidratadas com acetonitrila e digeridas com tripsina em uma concentração final de $20 \mathrm{ng} / \mu \mathrm{L}$ (Promega, Fitchburg, WI, Estados Unidos), a $58{ }^{\circ} \mathrm{C}$ por 30 minutos. Os peptídeos resultantes foram extraídos dos géis pela adição de $60 \mu \mathrm{L}$ de solução de ácido fórmico $30 \%$ e acetronitrila $50 \%$ em duas sessões de ultrassonificação por 10 minutos. A amostra foi concentrada à um volume final de $10 \mu \mathrm{L}$ em SpeedVac ${ }^{\mathrm{TM}}$ (Thermo Fischer Scientific, Waltham, MA, Estados Unidos) e dessalinizadas com ZipTip ${ }^{\text {TM }}$ (Millipore, Billerica, MA, Estados Unidos). Os peptídeos foram identificados por espectrometria de massas com ionização por desorção a laser, auxiliada por matriz e análise por tempo de voo (MALDI-TOF). Para tanto, as amostras foram misturadas 1:1 com a matriz $\alpha$-ciano-4hidroxicinâmico (CHCA) (SIGMA, St. Louis, MI, Estados Unidos) e transferidas para a placa Anchorchip 600 do MALDI-TOF/TOF AutoflexIII ${ }^{\text {TM }}$ (Bruker Daltonics, Billerica, MA, United States). Os íons carregados positivamente foram analisados no modo refletido. Os espectros MS e a relações de massas MS/MS foram utilizadas para identificação das proteínas com o algoritmo Mascot (Matrix Science, London, Reino Unido) e comparados com bancos de dados mantido pelo National Center for Biotechnology Information (NCBI) (http://www.ncbi.nlm.nih.gov). 


\subsection{Tolerância de E. antarcticum em ambientes extraterrestres simulados}

\subsubsection{Condições gerais}

Para a realização dos experimentos foram utilizadas as bactérias psicrotróficas Exiguobacterium antarcticum B7; Planococcus halocryophilus Or1 cedida gentilmente pelo laboratório do Prof. Lyle Whyte, McGill University, Canada; e a bactéria radio resistente Deinococcus radiodurans obtida junto ao Laboratório de Astrobiologia (USP).

As bactérias foram inoculadas em placas de ágar triptona de soja (TSA) e incubadas à $25^{\circ} \mathrm{C}$ até o surgimento de colônias de cerca de $1 \mathrm{~mm}$ de diâmetro. Uma colônia foi então ressuspensa em $100 \mu \mathrm{L}$ de $\mathrm{H}_{2} \mathrm{O}$ ultrapura estéril, $2 \mu \mathrm{L}$ da solução de bactérias foi então depositada em placas de silício estéreis de $1 \mathrm{~mm}^{2}$ e secas em temperatura e umidade ambiente por 24 horas para desidratação das amostras.

As bactérias foram expostas a três condições que simulam ambientes distintos: Meio interplanetário; Superfície da Terra; Superfície de Marte.

Após a exposição, as placas de silício foram mergulhas em $1 \mathrm{~mL}$ de caldo triptona de soja 20\% em PBS e agitadas vigorosamente por 1 minuto. Em seguida, as amostras foram diluídas e alíquotas de $20 \mu \mathrm{L}$ foram semeadas em placas de TSB e incubadas à $25^{\circ} \mathrm{C}$.

O índice de células sobreviventes foi determinada a partir do quociente N/N0, onde:

- $\quad \mathrm{N}=$ unidades formadoras de colônia (UFC) após o tratamento;

- $\quad \mathrm{N} 0=$ Grupo controle, composto pelo número de unidades formadoras de colônia obtidas posterior ao processo de dessecação, porém não irradiadas.

Todos os experimentos foram realizados em triplicata.

3.2.2 Simulação de radiação e vácuo do espaço interplanetário

Os experimentos de simulação de radiação e vácuo encontrados no espaço interplanetário foram realizados no Laboratório Nacional de Luz Síncrotron, localizado em Campinas, Brasil, integrante do Centro Nacional de Pesquisa em Energia e Materiais (CNPEM). Neste estudo foi utilizada a linha de luz síncrotron equipada com 
um monocromador de grade toroidal (TGM) e uma estação final com uma câmara de vácuo (CAVASSO FILHO et al., 2007).

As amostras foram mantidas à temperatura ambiente, e expostas ao vácuo e à radiação ultravioleta de vácuo (VUV), de comprimentos de onda menores do que 200nm. Um filtro de gás neônio entre a linha de luz e a câmara experimental foi utilizado para atenuar a radiação correspondente ao raio- $X$ do espectro total de radiação síncrotron. A emissão síncrotron resultante variou dentro dos comprimentos de onda de $57.6 \mathrm{~nm}$ até $124 \mathrm{~nm}$ e o espectro resultante está descrito na figura 7 .

As amostras foram expostas em fluências iguais a 0 (controle), 10, 50, 100, 500 e $1000 \mathrm{~J} . \mathrm{m}^{-2}$. A irradiância da linha de luz TGM é comparada com aquelas das órbitas da Terra, Marte e Europa (ABREVAYA et al., 2011; PAULINO-LIMA et al., 2011).

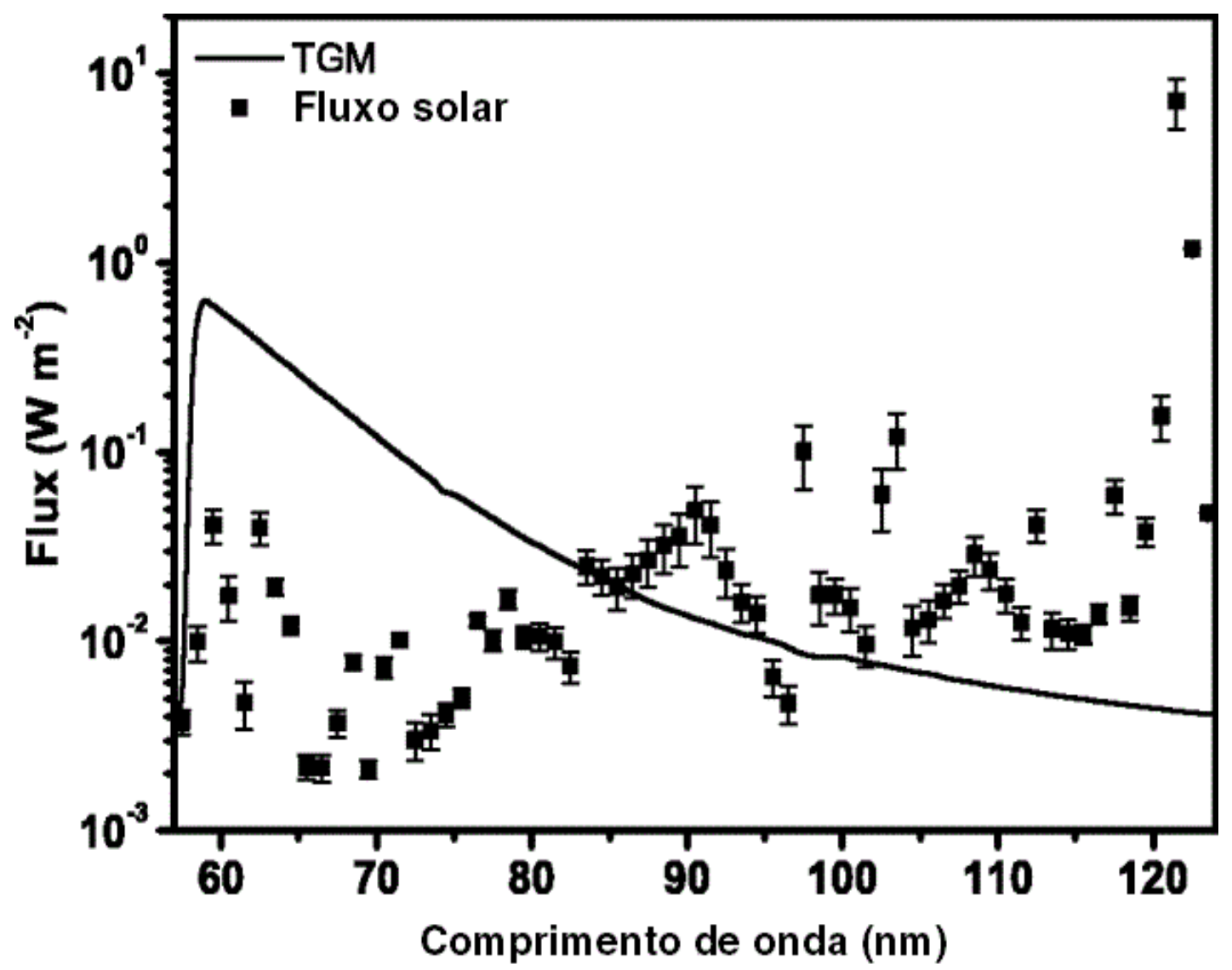

Figura 7 - O espectro correspondente a linha de luz associado a monocromador de grade toroidal em comparação com o fluxo solar obtida com espectro solares diários de 1999-2010. As barras de erro representam a variação do fluxo ao longo dos anos. Adaptado de Abrevaya (2011).

\subsubsection{Simulação de exposição à radiação solar terrestre}

Este experimento foi realizado no Laboratório de Astrobiologia da Universidade de São Paulo (AstroLab), Valinhos, SP, visando estimar a resistência das bactérias, 
quando expostas aos diferentes fluxos de radiação solar presentes na Terra. Um simulador de luz solar Oriel® (California, Estados Unidos) Sol UV-2 gerou um espectro simulando o perfil de fluxo solar nas faixas de UVA (315 até $400 \mathrm{~nm}$ ) e UVB (280 até $315 \mathrm{~nm}$ ), com fluxos de $12,3 \mathrm{~mW} . \mathrm{cm}^{-2}$ e $7,4 \mathrm{~mW} . \mathrm{cm}^{-2}$, respectivamente. Foi utilizado um filtro que bloqueia a radiação UVC e a luz visível, o espectro gerado pelo simulador solar com o filtro é mostrado na figura 8. As amostras foram expostas por 0 (controle), $5,10,20,30$ e $40 \mathrm{~min}$, a temperatura ambiente.

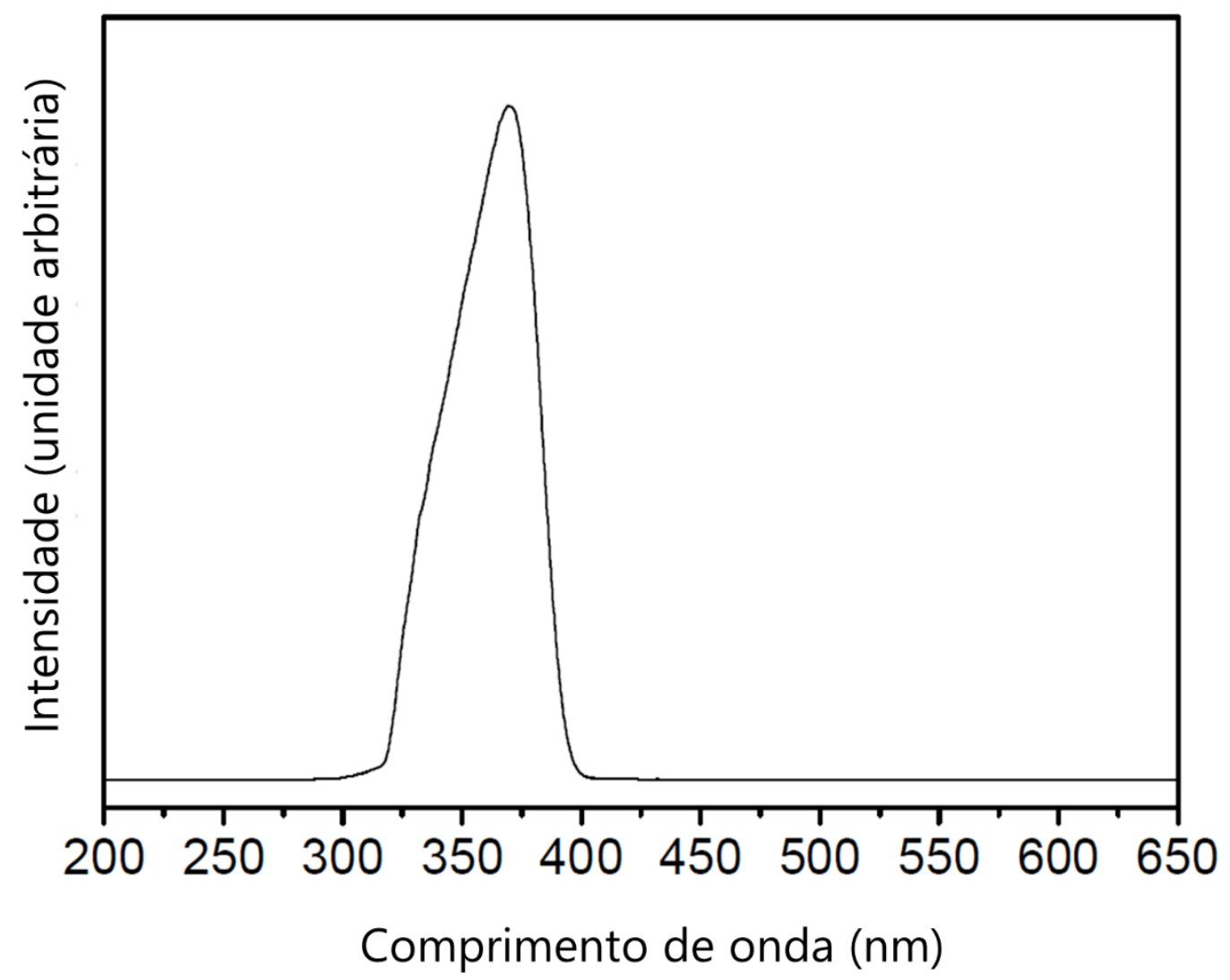

Figura 8 - Espectro produzido pelo simulador solar Oriel® Sol UV-2 equipado com filtros que simulam a radiação solar presente na superfície terrestre. Adaptado de Pulschen (2015).

\subsubsection{Simulação de condições da superfície de Marte}

Neste experimento, também realizado no AstroLab-USP, foi utilizado uma câmara de simulação de ambientes espaciais capaz de simular vários parâmetros ambientais, tais como a pressão, a composição da atmosfera, radiação e temperatura, mostrada na figura 9. As amostras foram submetidas à pressão similar à superfície de Marte (8mbar) e temperatura de $-20^{\circ} \mathrm{C}$, compatível com a temperatura da superfície do planeta. Quanto a composição atmosférica, foi utilizada uma mistura gasosa que se aproxima da encontrada em Marte com 95\% de $\mathrm{CO}_{2}$ e $5 \%$ de $\mathrm{N}_{2}$. Os experimentos 
de radiação simularam a faixa espectral de radiação ultravioleta gerada dentro da faixa espectral de 200-400 nm com base em um modelo de Marte descrito anteriormente com intensidades de radiação em porcentagens conhecidas (SCHUERGER et al., 2006).

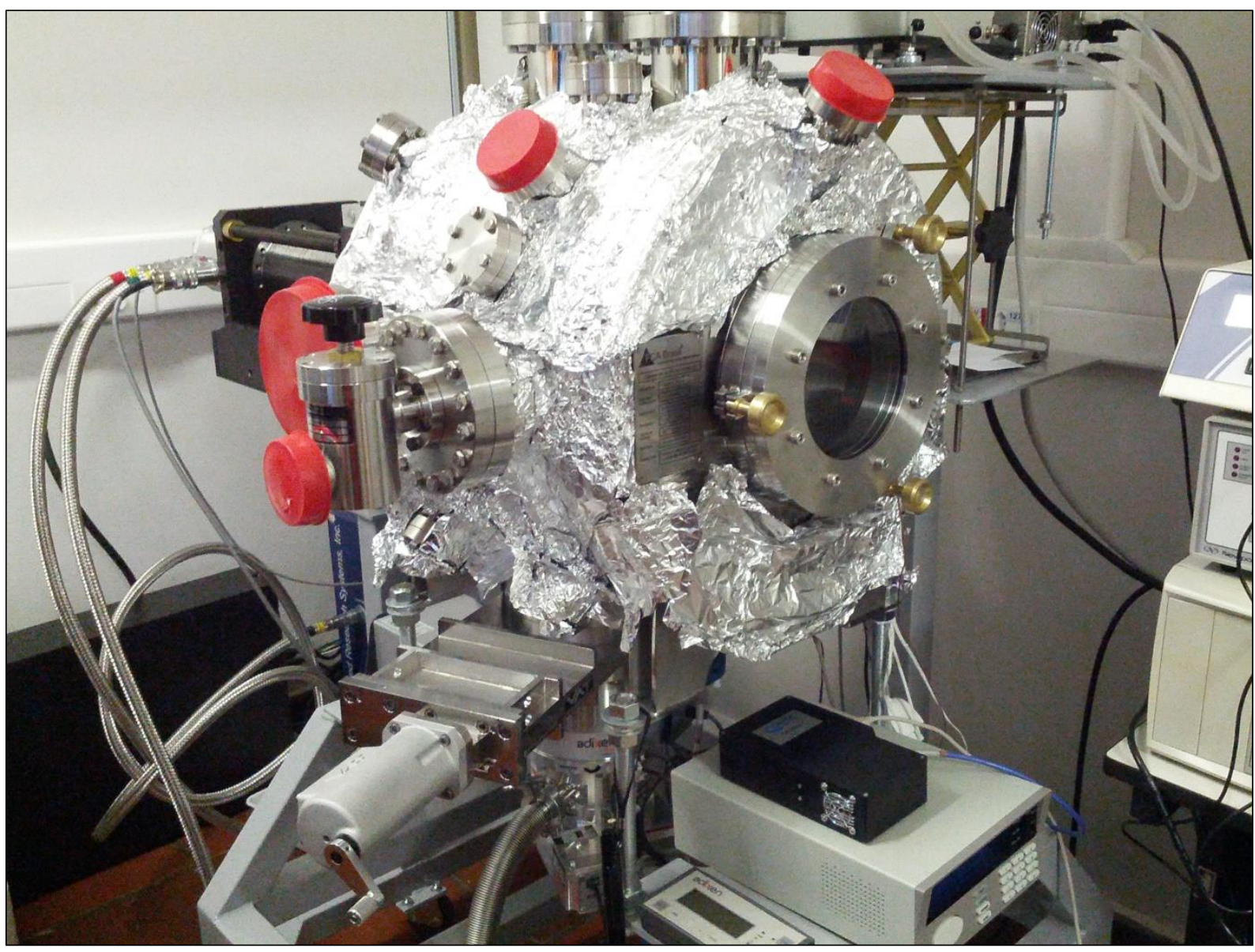

Figura 9 - Câmara de simulação de ambientes espaciais (AstroLab-USP). 


\subsection{Prospecção de micro-organismos adaptados à anidrobiose}

\subsubsection{Amostras de solo}

As amostras de solo utilizadas para o isolamento de organismos resistentes à dessecação foram coletas de 3 regiões distintas, duas da Antártica (Figura 10) - solo exposto pelo recuo da geleira Baranowski e solo da Ilha Deception - e uma do Ártico Canadense (Figura 12). Todas as amostras foram armazenadas sob refrigeração (-20 ${ }^{\circ} \mathrm{C}$ à $-50{ }^{\circ} \mathrm{C}$ ) desde a sua coleta até o momento de sua utilização. Uma lista simplificada das amostras utilizadas nesta seção do estudo encontra-se na Tabela 1.

Tabela 1 - Ralação das amostras de solo utilizadas para o isolamento de micro-organismos adaptados à dessecação.

\begin{tabular}{|c|c|c|c|}
\hline Amostra & Solo & Local & Coordenadas \\
\hline Dec85 & Borda da caldeira de Deception & Deception Island, Antártica & $\begin{array}{c}62^{\circ} 55^{\prime} 21.55^{\prime \prime S} \\
60^{\circ} 38^{\prime} 7.19^{\prime \prime} \mathrm{O}\end{array}$ \\
\hline Dec92 & Borda lago geotermal & Deception Island, Antártica & $\begin{array}{l}62^{\circ} 58^{\prime} 50.00 " \mathrm{~S} \\
60^{\circ} 34^{\prime} 24.00^{\prime \prime}\end{array}$ \\
\hline Dec94 & Borda lago geotermal & Deception Island, Antártica & $\begin{array}{l}62^{\circ} 58^{\prime} 46.31 " \mathrm{~S} \\
60^{\circ} 34^{\prime} 31.65 " \mathrm{O}\end{array}$ \\
\hline Bas01 & Distância da geleira Baranowski: 0 m & Baranowsky, Antártica & $\begin{array}{l}62^{\circ} 11 ' 53.42 " \mathrm{~S} \\
58^{\circ} 26^{\prime} 53.19^{\prime \prime}\end{array}$ \\
\hline Bas06 & Distância da geleira Baranowski: 189 m & Baranowsky, Antártica & $\begin{array}{l}62^{\circ} 11^{\prime} 52.87^{\prime \prime} \mathrm{S} \\
58^{\circ} 26^{\prime} 40.19^{\prime \prime O}\end{array}$ \\
\hline Bas12 & Distância da geleira Baranowski: 473 m & Baranowsky, Antártica & $\begin{array}{l}62^{\circ} 11 ' 52.56^{\prime \prime S} \\
58^{\circ} 26^{\prime} 20.62^{\prime \prime O}\end{array}$ \\
\hline ArcA & Camada ativa - Profundidade: $25 \mathrm{~cm}$ & Axel Heiberg, Ártico & $\begin{array}{l}79^{\circ} 24^{\prime} 57.90 " \mathrm{~N} \\
90^{\circ} 45^{\prime} 48.12^{\prime \prime} \mathrm{O}\end{array}$ \\
\hline ArcM & Camada de transição - Profundidade: $50 \mathrm{~cm}$ & Axel Heiberg, Ártico & $\begin{array}{l}79^{\circ} 24^{\prime} 57.90 " \mathrm{~N} \\
90^{\circ} 45^{\prime} 48.12^{\prime \prime} \mathrm{O}\end{array}$ \\
\hline ArcP & Permafrost - Profundidade: $100 \mathrm{~cm}$ & Axel Heiberg, Ártico & $\begin{array}{l}79^{\circ} 24^{\prime} 57.90 " \mathrm{~N} \\
90^{\circ} 45^{\prime} 48.12^{\prime \prime} \mathrm{O}\end{array}$ \\
\hline
\end{tabular}

As amostras de solo da llha Deception, Antártica, foram coletadas durante a Operação Antártica XXV (verão 2006/2007) pela equipe do LECOM-USP, em 3 pontos distintos, próximos a anomalias geotérmicas (Figura 11). Duas amostras, denominadas Dec-92 e Dec-93, foram retiradas próximas ao lago Kroner, a temperaturas de $10{ }^{\circ} \mathrm{C}$ e $6{ }^{\circ} \mathrm{C}$, respectivamente. A amostra Dec-85 foi coletada em solo da borda da caldeira vulcânica entre Telefon bay e Pendulum, a uma temperatura de cerca de $5{ }^{\circ} \mathrm{C}$. 


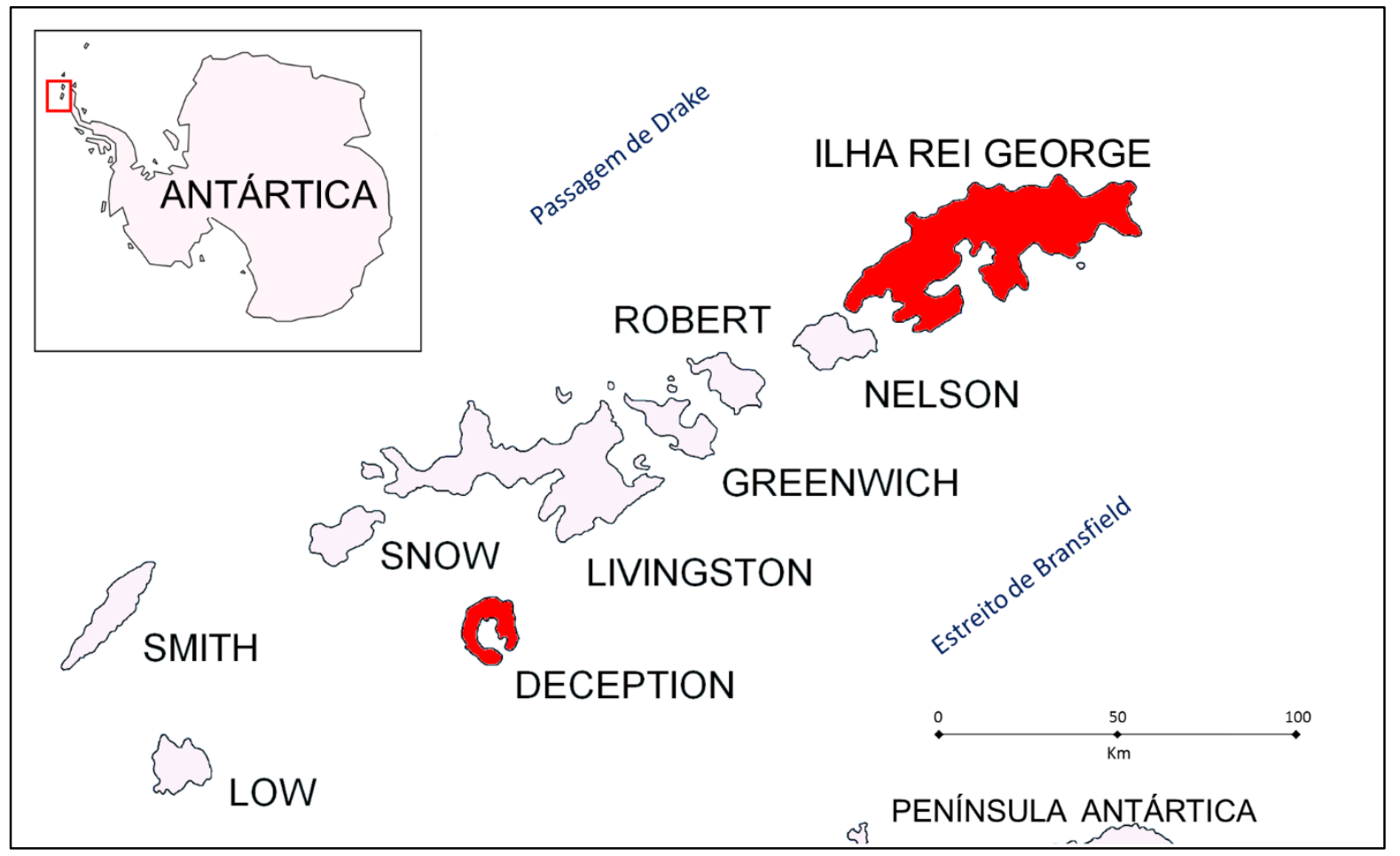

Figura 10 - Representação das ilhas Shetland do Sul, Antártica. Em vermelho as ilhas Rei George e Deception.

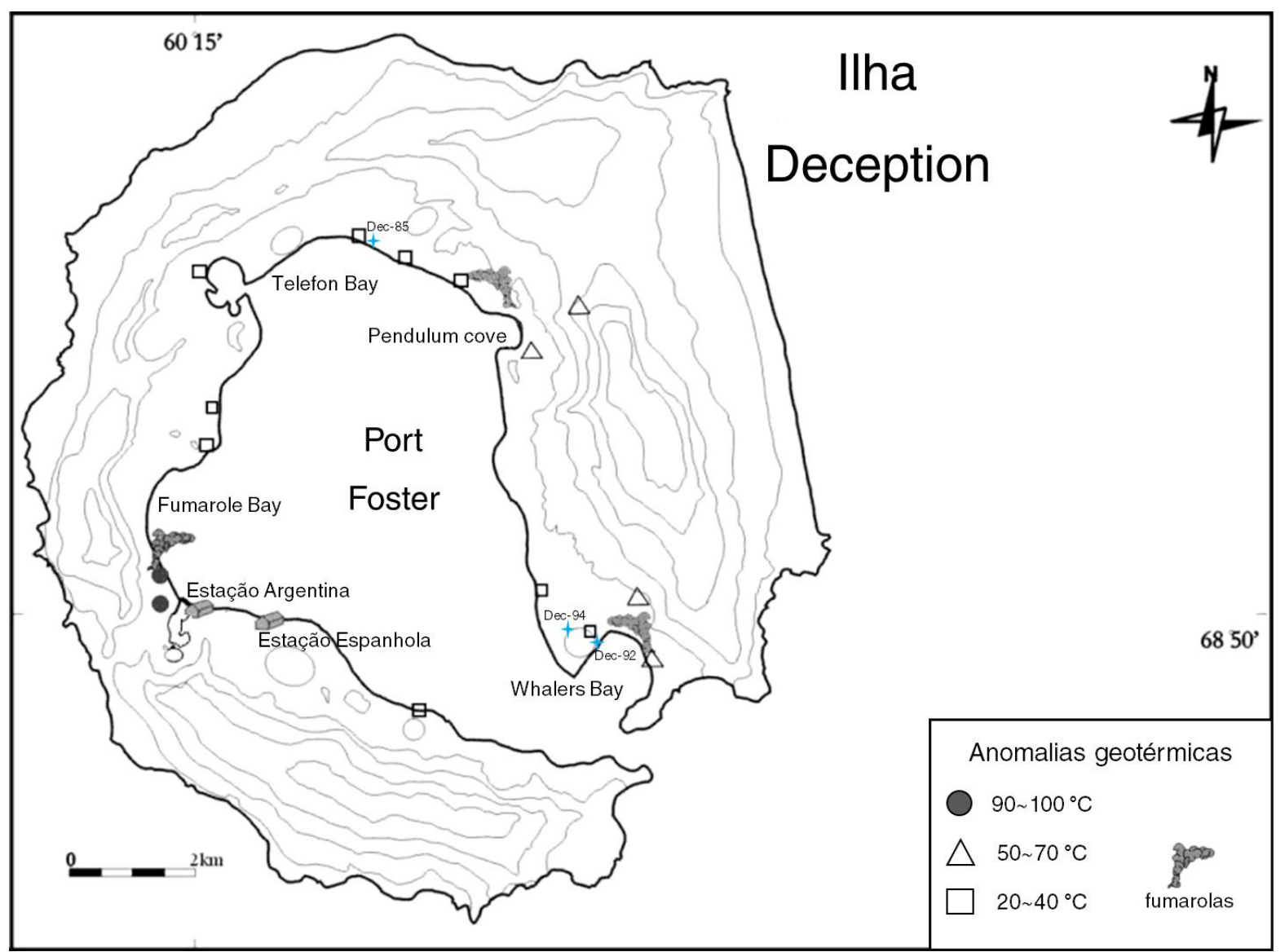

Figura 11 - Mapa da llha Deception, Antártica, e suas zonas geotermicamente ativas. As estrelas azuis indicam a localização aproximada dos sítios de coleta das amostras. Fonte: Adaptado de Caselli (2004) 
As amostras de solo exposto pela geleira Baranowski, localizada na Ilha Rei George, foram coletadas junto ao Programa Antártico Brasileiro (PROANTAR/CNPq), pelo Prof. Dr. Rubens Tadeu Duarte, durante a Operação Antártica XXVII (verão 2008/2009). A geleira Baranowski, apresentou um recuo de aproximadamente $450 \mathrm{~m}$ entre 1985-2010, recuo médio de cerca de 18 metros por ano (DUARTE, 2010). As amostras de solo utilizadas foram coletadas em um transecto de $500 \mathrm{~m}$ perpendicular à frente da geleira, a uma profundidade de $1-5 \mathrm{~cm}$ (Figura 12).

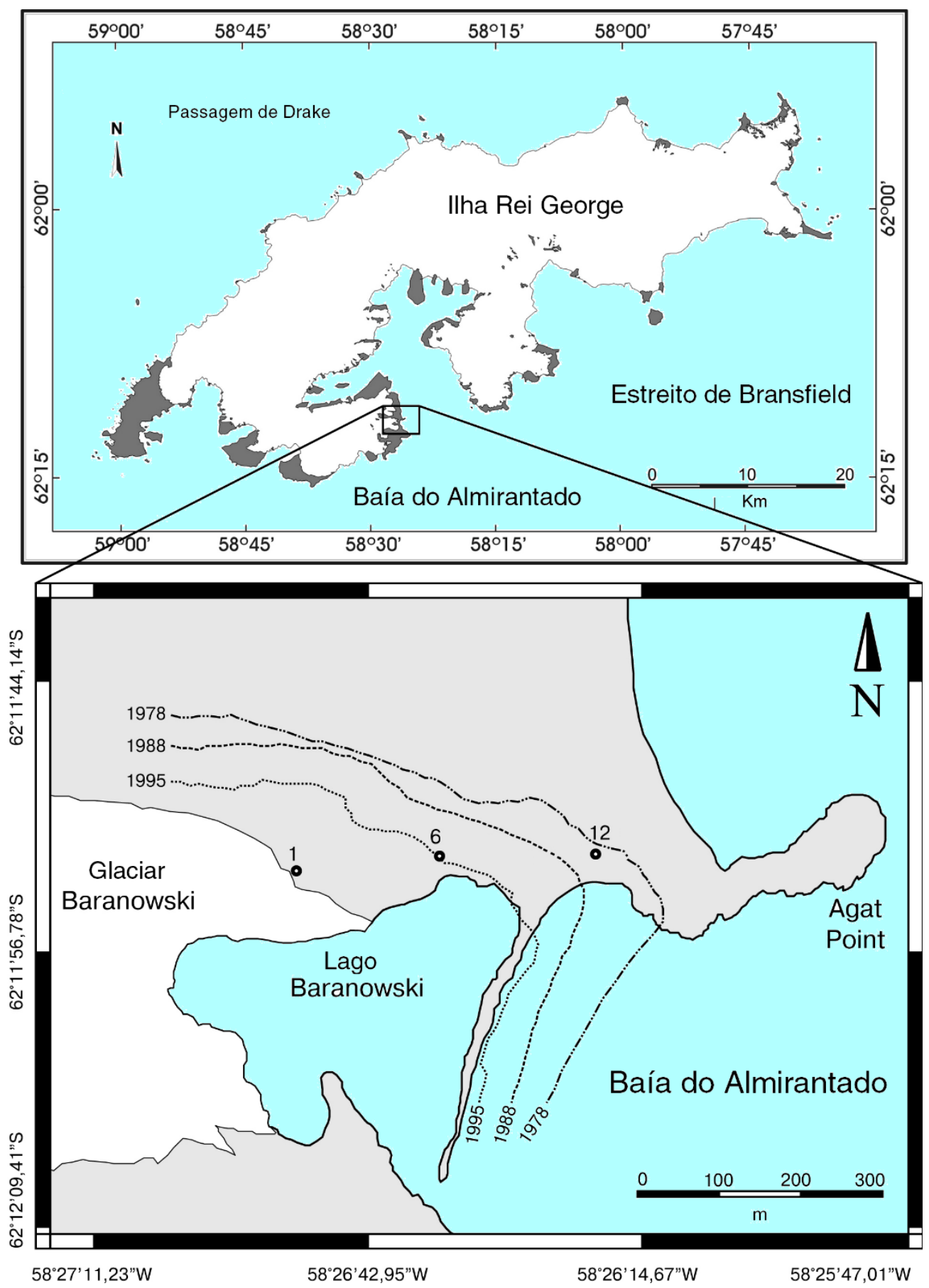

Figura 12 - Mapa da área de solo exposto por recuo da geleira Baranowski, indicando os pontos de coleta. Adaptado de Duarte, 2010. 
Amostras de uma região de solo poligonal do Ártico canadense, foram coletadas e utilizadas em cooperação com o Prof. Dr. Lyle Whyte, da McGill University, com auxílio do programa Ciência Sem Fronteiras. O campo de solo poligonal amostrado é caracterizado por um solo ácido ( $\mathrm{pH} \mathrm{4,5} \mathrm{-} \mathrm{5),} \mathrm{conduzido} \mathrm{principalmente}$ pela química de ferro-enxofre e está localizado nas proximidades da McGill Arctic Research Station (MARS) a $8 \mathrm{~km}$ no interior da ilha Axel Heiberg, Canadá, de coordenadas 7926' N e 9046' O (Figura 13) (BUTTLE; FRASER, 1992; POLLARD et al., 2009). A temperatura média da região em 2009 foi de $-18,8^{\circ} \mathrm{C}$, registrada por uma estação meteorológica localizada na ilha adjacente, Eureka. As temperaturas médias do mês mais frio (janeiro) foi de $-37,4^{\circ} \mathrm{C}$ e do mais quente (julho) $6,1^{\circ} \mathrm{C}$.

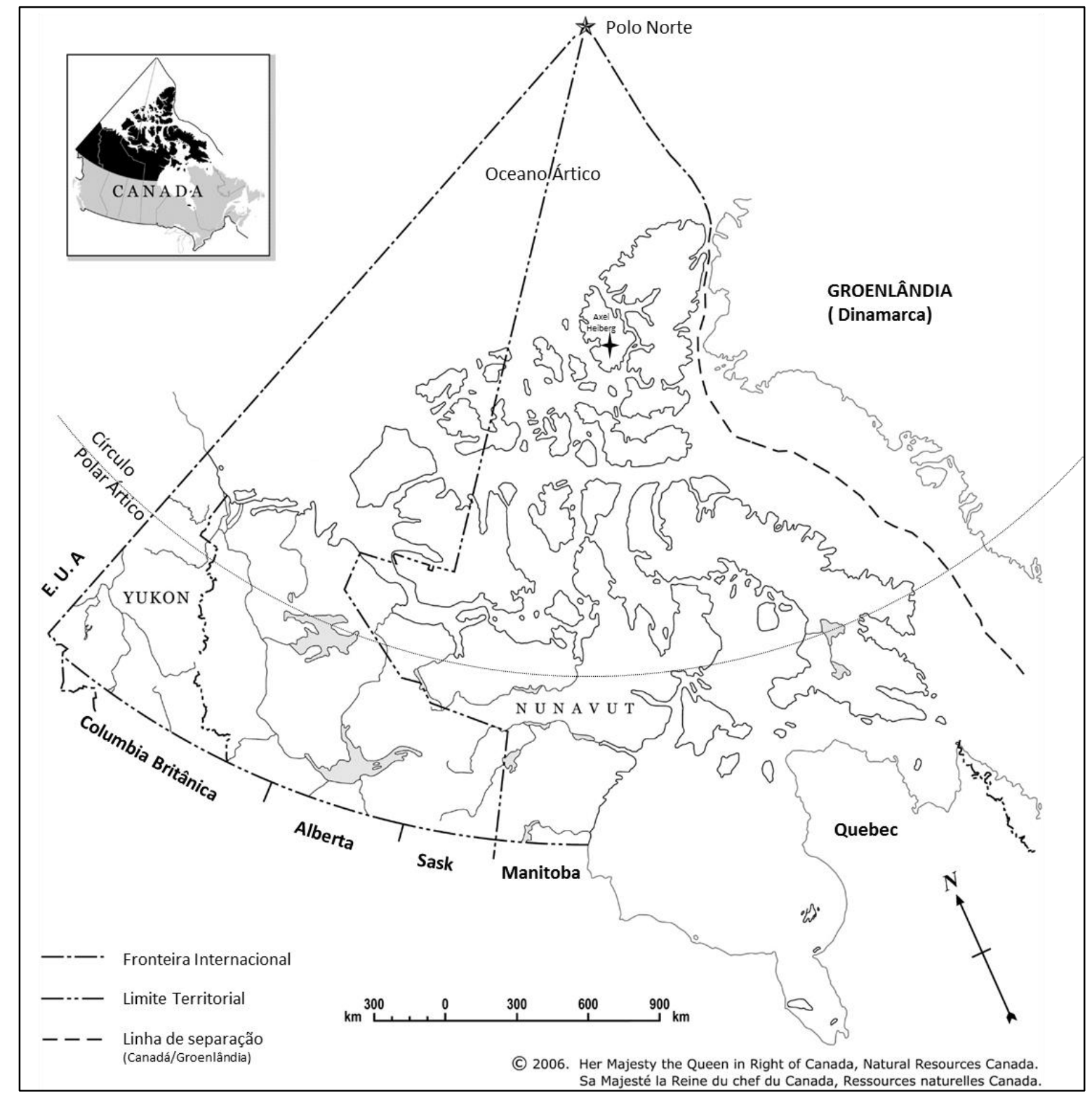

Figura 13 - Mapa do Territórios do Canadá que compõem o Ártico Canadense.Cruz indica a localização aproximada da estação MARS na ilha de Axel Heiberg. Adaptado de "The Atlas of Canada", Natural Resources - Government of Canada. 
As amostras de permafrost utilizadas foram coletadas em julho de 2010 em testemunho cilíndrico e separadas de acordo com sua profundidade (Figura 14):

i) Camada ativa (congela no inverno e descongela no verão);

0 - 38 centímetros

ii) Camada mediana (interface o permafrost e a camada ativa);

39 - 76 centímetros

iii) Permafrost (solo permanentemente congelado).

77 - 120 centímetros

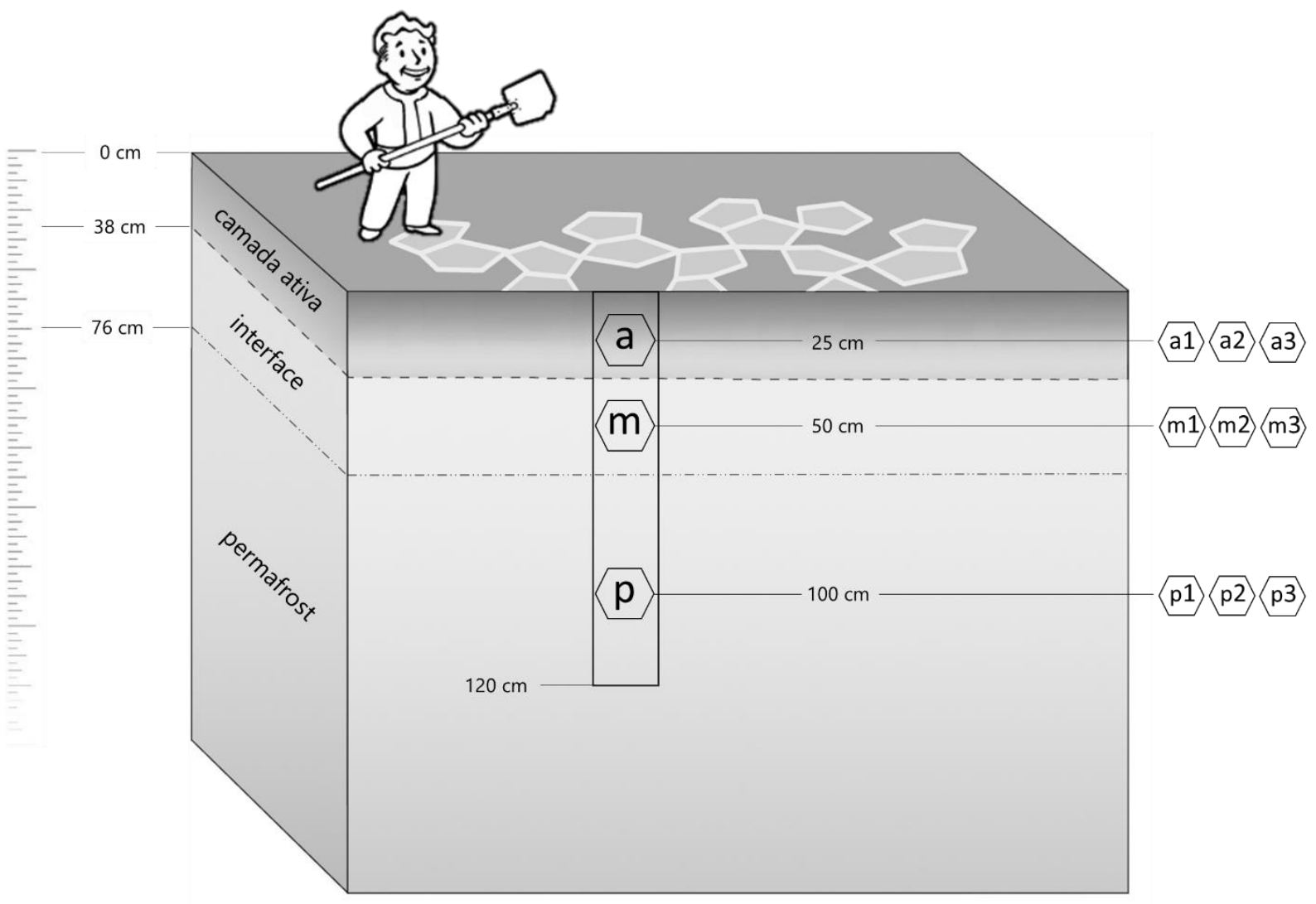

Figura 14 - llustração do testemunho de solo coletado em Axel Heiberg. Linhas tracejadas indicam os limites entre as camadas.

\subsubsection{Isolamento de bactérias resistentes à dessecação e a baixas temperaturas}

5 gramas de solo seco ao ar foram misturadas com $10 \mathrm{~mL}$ de clorofórmio e incubado por 30 minutos sob agitação suave, em experimento adaptado ao descrito por Narvaez-Reinaldo (2010). Após a incubação, as misturas foram transferidas para placas de vidro estéreis durante mais 30 minutos para permitir a evaporação completa do clorofórmio. Ao solo tratado com clorofórmio e seco foi adicionado $10 \mathrm{~mL}$ de meio de cultura triptona de soja (TSB). Diluições em série em tampão de solução salina 
foram feitas por 3 vezes e alíquotas de $100 \mu \mathrm{L}$ de cada diluição foram plaqueadas nos meios de cultura TSA e R2A.

As placas foram incubadas a $30^{\circ} \mathrm{C}$ e a $4{ }^{\circ} \mathrm{C}$ por um período de 3 dias e por 1 mês, respectivamente. Os experimentos foram realizados em triplicatas. Após o período de incubação as colônias foram enumeradas para posterior caracterização.

\subsubsection{Caracterização dos isolados}

As colônias foram preparadas para análise de seu DNA pelo método de fervura que desnatura e inativa as proteínas celulares. Para isso, as colônias foram selecionadas retirando-as do meio de cultura, com o auxílio de uma pipeta estéril, e dissolvidas em $500 \mu \mathrm{L}$ de água ultrapura. A solução foi então aquecida a $100{ }^{\circ} \mathrm{C}$ durante 3 minutos e em seguida armazenada a $4 \stackrel{\circ}{ } \mathrm{C}$. Para a seleção de filotipos únicos, foi utilizado o método de amplificação de uma região do genoma bacteriano conhecida como BOX, composta de sequências curtas e repetitivas (MARTIN et al., 1992). Foram utilizados para a reação de BOX-PCR: Go Taq Green 1X (Promega) (contendo os dNTPs, a enzima polimerase e solução tampão), 0,6 mM de primer BOXA1R (SMITH; HENNESSY; STEAD, 2001), $2 \mu \mathrm{L}$ (cerca de $20 \mathrm{ng}$ ) de DNA extraído e $\mathrm{H}_{2} \mathrm{O}$ para um volume final de $50 \mu \mathrm{L}$. O termociclador foi programado para uma temperatura de desnaturação de $94^{\circ} \mathrm{C}$, anelamento de $53^{\circ} \mathrm{C}$, e extensão de $65{ }^{\circ} \mathrm{C}$, em um ciclo repetido por 35 vezes. O perfil das amostras foi avaliado por eletroforese em gel de agarose $1,5 \%(\mathrm{~m} / \mathrm{v})$ contendo $5 \mu \mathrm{L}$ de SYBR Safe (Invitrogen, Carlsbad, CA, United States) a cada $100 \mathrm{~mL}$ de gel. Cerca de $5 \mu \mathrm{L}$ do marcador molecular - $1 \mathrm{~Kb}$ DNA Ladder (Invitrogen) - foi utilizado para calibrar a migração das bandas das amostras entre diferentes géis. A eletroforese foi submetida a uma voltagem de 100 $\checkmark$ por aproximadamente 4 horas e em seguida o gel foi visualizado e registrado em um foto-documentador com luz ultravioleta. $A$ análise dos perfis de bandas de BOXPCR foi realizada com o auxílio do software BioNumerics (Applied Maths, SintMartens-Latem, Bélgica).

As colônias de filotipos únicos foram selecionadas para identificação a partir do sequenciamento do gene rRNA 16S, seguindo reação de amplificação como descrita no item anterior, porém com temperatura de anelamento de $55^{\circ} \mathrm{C}$ e utilizando o par de primers 27F (5' AGA GTT TGA TCM TGG CTC AG 3') e 1401R (5' CGG TGT GTA CAA GAC CC 3'). O produto de PCR foi submetido a sequenciamento no Plate-forme 
d'analyses biomoléculaires, Université Laval - Canadá, no qual foi sequenciado pelo método de Sanger, utilizando o primer 27F como iniciador, gerando uma sequência de boa qualidade até cerca de 700pb (SANGER; NICKLEN; COULSON, 1977). As sequências foram comparadas ao banco de sequências de RNA 16S SILVA, que mantém coleção de dados frequentemente atualizada e de qualidade controlada, e comparadas com o algoritmo SINA para alinhamento e classificação taxonômica das sequências (PRUESSE; PEPLIES; GLÖCKNER, 2012; QUAST et al., 2013). A árvore filogenética das sequências provenientes do gene rRNA 16S dos isolados foi inferida pelo método de Neighbor Joining a partir das sequências únicas alinhadas de todos os isolados com o pacote de software ARB (LUDWIG et al., 2004). A árvore foi desenhada em escala, com comprimentos dos ramos nas mesmas unidades às das distâncias evolutivas usadas para inferir a árvore filogenética. As distâncias foram calculadas usando o método de máxima verossimilhança e estão nas unidades do número de substituições de base por sítio. As seqüências foram também submetidas ao banco de dados de seqüência genética GenBank (Submission ID: SUB1160085).

\subsubsection{Análise de resistência à dessecação}

Os isolados foram inoculados em placas de ágar de soja e triptona (TSA) e incubadas a $30^{\circ} \mathrm{C}$ ou $0{ }^{\circ} \mathrm{C}$, dependendo dá temperatura em que a bactéria foi isolada, até o surgimento de colônias de cerca de $1 \mathrm{~mm}$ de diâmetro. Cada colônia foi então ressuspensa em $100 \mu \mathrm{L}$ de $\mathrm{H}_{2} \mathrm{O}$ ultrapura estéril e em seguida, $2 \mu \mathrm{L}$ da solução de bactérias foi depositada em placas de silício estéreis de $1 \mathrm{~mm}^{2}$ e incubadas em um dessecador, ao abrigo da luz (Umidade Relativa 4\%), por 1 semana, 2 semanas e 1 mês. Após esse período as bactérias foram depositadas em um frasco estéril com $1 \mathrm{~mL}$ de PBS, e agitadas por 1 minuto. $100 \mu \mathrm{L}$ dessa solução foi plaqueada em meio TSA, e incubada a $30^{\circ} \mathrm{C}$ ou $0^{\circ} \mathrm{C}$ até o aparecimento de colônias (BAUERMEISTER et al., 2011). O índice de células sobreviventes foi determinada a partir do quociente N/NO, onde:

- $\quad \mathrm{N}=$ unidades formadoras de colônia após o tratamento de dessecação;

- $\quad \mathrm{N} 0=$ Grupo controle, composto pelo número de unidades formadoras de colônia obtidas pelo mesmo procedimento, com exceção do período de 2 semanas de dessecação. 


\subsection{Diversidade microbiana em amostras de permafrost do ártico canadense}

As amostras utilizadas para o estudo da diversidade e composição microbiana de solo periglacial do Ártico canadense são as mesmas descritas na seção 3.3.1 e detalhadas na Figura 14.

\subsubsection{Extração de DNA total do solo}

Para cada camada de solo estudada foram realizadas três extrações de DNA independentes. Cada extração foi sequenciada e analisada de forma independente. As amostras foram classificas em:

- $\quad$ a1, a2 e a3 - réplicas da camada ativa (active layer) do testemunho de solo;

- $\quad$ m1, m2 e m3 - réplicas da camada de transição (middle layer);

- $\quad$ p1, p2 e p3 - réplicas da camada de solo permanentemente congelado (permafrost).

Foi realizada a extração de DNA genômico amostras de solo com o kit PowerMax ${ }^{\mathrm{TM}}$ Soil DNA (Mo Bio, Carlsbad, CA, Estados Unidos), a partir de $10 \mathrm{~g}$ de cada amostra, seguindo-se o protocolo recomendado pelo fabricante. A quantificação do DNA total realizada por espectrofotometria pelo aparelho NanoDrop ${ }^{\mathrm{TM}}$ ND-1000 (Thermo Scientific, EUA) e por fluorometria pelo o aparelho Qubit 1.0 (Life Technologies) com o kit Qubit® dsDNA HS Assay Kit (Life Technologies).

\subsubsection{Preparo da biblioteca de genes 16S rRNA das amostras de permafrost}

O preparo da biblioteca de genes 16S rRNA juntamente com a inserção de índices e adaptadores específicos para sequenciamento na plataforma Illumina está esquematizado na figura 15. A amplificação inicial do gene do RNAr 16S a partir do DNA genômico foi desenhada para amplificar as regiões V3 e V4 do gene do rRNA $16 \mathrm{~S}$ em bactérias. Esse conjunto de primers foi apontado como o mais promissor para o sequenciamento em plataformas de próxima geração (KLINDWORTH et al., 2013). O par de primers final utilizado, segundo o padrão de nomenclatura da IUPAC, foi:

Forward Primer $=5^{\prime}$

TCGTCGGCAGCGTCAGATGTGTATAAGAGACAGCCTACGGGNGGCWGC $A G$ 
Reverse Primer $=5^{\prime}$

GTCTCGTGGGCTCGGAGATGTGTATAAGAGACAGGACTACHVGGGTATC TAATCC

Cada primer possuía uma sequência de adaptadores específicos sendo eles: Adaptador Forward = 5' TCGTCGGCAGCGTCAGATGTGTATAAGAGACAG

Adaptador Reverse = 5' GTCTCGTGGGCTCGGAGATGTGTATAAGAGACAG

Finalmente, a sequência específica para anelamento no gene 16 rRNA e que completa o primer é:

\section{$341 \mathrm{~F}=5$ ' CCTACGGGNGGCWGCAG \\ 785R = 5' GACTACHVGGGTATCTAATCC}

A primeira reação de amplificação consistiu em $25 \mu \mathrm{L}$ da enzima KAPA HiFi HotStart Ready Mix (Kapa Biosystems, Wilmington, Massachusetts, Estados Unidos), aproximadamente $5 \mathrm{ng}$ de DNA genômico e 0,2 $\mu \mathrm{M}$ de cada primer. A PCR consistiu em uma desnaturação inicial a $95{ }^{\circ} \mathrm{C}$ por 3 minutos, seguida de 30 ciclos a $95{ }^{\circ} \mathrm{C}$ por 30 segundos, anelamento a $55^{\circ} \mathrm{C}$ por 30 segundos e extensão a $72 \stackrel{\circ}{\mathrm{C}}$ por 30 segundos, finalizada com uma extensão final a $72 \stackrel{\circ}{\mathrm{C}}$ por 5 minutos. Devido a presença de dímeros de primers, e amplificações inespecíficas, as bandas referentes aos amplicons foram cortadas do gel e purificadas através do kit QIAquick Gel Extraction (QIAGEN, Hilden, Alemanha). O DNA amplificado foi quantificado através de fluorômetro Qubit® 1.0 (Life Technologies) com o kit Qubitß dsDNA HS Assay Kit (Life Technologies). Em seguida, aproximadamente $50 \mathrm{ng}$ de DNA foi utilizado para realizar a segunda reação de amplificação que consistiu na adição de índices em cada amplicon do gene do rRNA 16S para a montagem das bibliotecas. Os índices são compostos por dois conjuntos de primers (12 primers de índices "tipo 1" e 8 primers de índices "tipo 2" possibilitando 96 combinações diferentes). A PCR de adição dos índices consistiu em uma desnaturação inicial de $95 \stackrel{\circ}{\mathrm{C}}$ por 3 minutos, 8 ciclos de 95 ${ }^{\circ} \mathrm{C}$ a 30 segundos, $55^{\circ} \mathrm{C}$ a 30 segundos e $72{ }^{\circ} \mathrm{C}$ a 30 segundos, e extensão final de $72 \stackrel{\circ}{ } \mathrm{C}$ por 5 minutos. 
Primeira PCR: Amplificação do fragmento V3-V4 do gene 16S rRNA e adição de conectores

Primer dianteiro com região de afinidade ao gene $16 \mathrm{~S}$ mais conector sobressalente

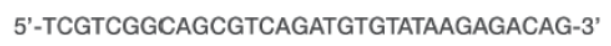

Primer traseiro com região de afinidade ao

gene $16 \mathrm{~S}$ mais conector sobressalente

5'-GTCTCGTGGGCTCGGAGATGTGTATAAGAGACAG-3'

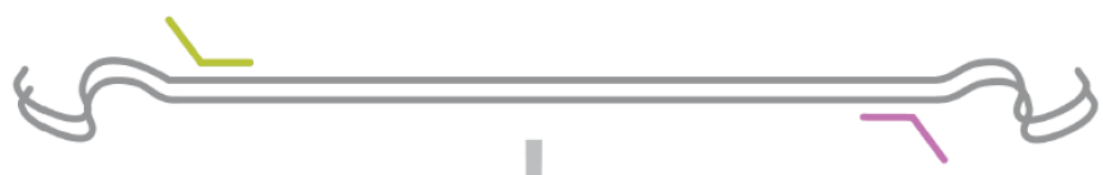

Segunda PCR: Adição de índices e adaptadores de sequenciamento para plataforma Illumina

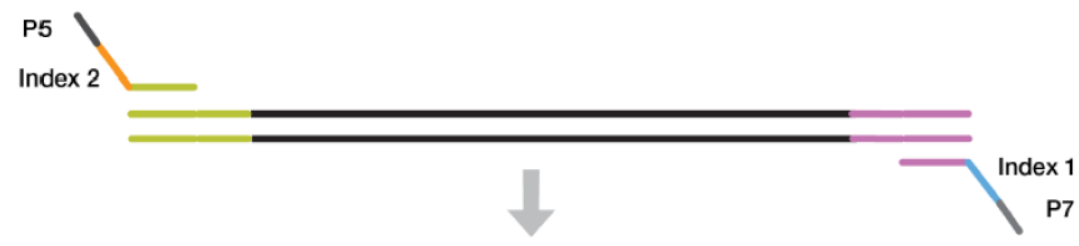

Normalização e pool das bibliotecas

\section{Sequenciamento}

Figura 15 - Preparo da biblioteca para sequenciamento na pelo sistema Illumina, esquematizado.

Os amplicons, agora contendo os índices e denominados de "bibliotecas", foram purificados por beads magnéticas através do kit AMPure XP beads (Beckman Coulter, Brea, CA, Estados Unidos). A purificação consistiu na adição de $56 \mu \mathrm{L}$ das beads magnéticas em cada biblioteca. A placa contendo as amostras foi inserida em um rack magnético por 2 minutos ou até que o sobrenadante se tornasse transparente. O sobrenadante foi removido e $200 \mu \mathrm{L}$ de etanol a $80 \%$ foi adicionado para a lavagem do DNA. O etanol $80 \%$ foi removido e $25 \mu \mathrm{L}$ de $10 \mathrm{mM}$ Tris $\mathrm{pH} 8,5$ foi adicionado em cada amostra para a eluição do DNA purificado.

As bibliotecas foram analisadas quanto a sua qualidade por Bioanalyzer 2100 (Agilent Technologies, Santa Clara, CA, Estados Unidos), utilizando a placa Bioanalyzer DNA 1000 (Agilent Technologies) disponibilizado pelo Centro Avançado de Tecnologias em Genômica - CATG do Instituto de Química da USP. Também foi aferido a concentração das bibliotecas por análise fluorimétrica pelo aparelho Qubit 
1.0 (Life Technologies) com o kit Qubit® dsDNA HS Assay Kit (Life Technologies), de acordo com as orientações do fabricante.

Em seguida, foi efetuada a normalização das bibliotecas para $4 \mathrm{nM}$, por meio da seguinte fórmula:

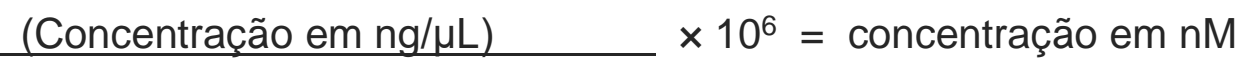
$(660 \mathrm{~g} / \mathrm{mol} \times$ tamanho médio da biblioteca)

Ao fim, foi realizada a etapa final de pooling, que consistiu em juntar todas as bibliotecas normalizadas em uma única solução para o sequenciamento.

\subsubsection{Sequenciamento da biblioteca de genes na plataforma Illumina MiSeq}

O pool final de bibliotecas foi enviado ao Centro de Facilidades de Apoio à Pesquisa (CEFAP), localizado no Instituto de Ciências Biomédicas (ICB) da USP para sequenciamento em conjunto na plataforma Illumina MiSeq. Em preparação para a geração dos clusters e sequenciamento, o pool de bibliotecas foi desnaturado com $\mathrm{NaOH}$, diluído com tampão de hibridização, e em seguida, desnaturado por calor antes do sequenciamento, seguindo as especificações do fabricante. À biblioteca foi adicionado 5\% do controle interno PhiX para regiões de baixa variação de bases.

A fabricante lllumina recomenda o preparo de pool de bibliotecas visando densidades de geração de cluster dentro da margem de $800-1000 \mathrm{~K} / \mathrm{mm}^{2}$ para otimização dos reagentes MiSeq v3. Para tanto foi calculado uma concentração final de DNA de 4 pM para a corrida.

O sequenciamento foi realizado na plataforma MiSeq juntamente com os reagentes e flow cell MiSeq v3, que gera reads de $301 \mathrm{pb}$, paired-end, por um total de 600 ciclos de amplificação. O sequenciamento foi acompanhado por 65 horas até seu término, pela plataforma online BaseSpace $\AA$ (Illumina). Todos os dados gerados foram enviados pelo equipamento MiSeq aos servidores da lllumina e descarregados pela plataforma BaseSpace $\AA$ para posterior análise de bioinformática.

\subsubsection{Análise in silico da biblioteca de genes 16S rRNA}

As sequências de 16S rRNA obtidas pelo sequenciamento foram curadas usando o protocolo descrito por Kozich et al. (2013) usando o software Mothur v 1.33.0 (Schloss et al. 2009). Ferramentas deste software em conjunto com o protocolo citado 
foram utilizadas para remoção de sequências referentes à primers e adaptadores, redução de erros de sequenciamento e PCR, alinhamento das sequências paired-end para formação de sequências contíguas (contigs). A remoção de sequências quimera foi realizada pelo mesmo software com a utilização do algoritmo UCHIME (EDGAR et al., 2011). Para facilitar o cálculo de índices de diversidade ecológica, as contigs foram agrupadas em unidades taxonômicas operacionais (OTU) utilizando um cutoff de 0,03.

Tanto para o cálculo dos índices de diversidade quanto para as análises de composição da comunidade bacteriana, foram utilizadas diferentes abordagens de comparação, hora comparando cada uma das nove amostras sequenciadas, hora comparando os três estratos do testemunho de solo (unindo as sequências de cada triplicata).

Curvas de rarefação foram calculada para cada uma das amostras e por estrato do testemunho de solo (HECK JR; VAN BELLE; SIMBERLOFF, 1975). A riqueza estimada das comunidades foi estimada pelos índices Chao1 e ACE (abundancebased coverage estimator) (CHAO, 1984; CHAO; LEE, 1992) e a diversidade pelos índices de Shannon e Simpson (SHANNON, 1948; SIMPSON, 1949). Análise de beta diversidade foram utilizados os índices de Bray-Curtis (BRAY; CURTIS, 1957) e o índice theta de Yue-Clayton (YUE; CLAYTON, 2005).

Todas as sequências contíguas foram alinhadas e classificadas taxonomicamente por comparação com o banco de dados de genes 16S rRNA SILVA (database 119) atráves do software MOTHUR v.1.33.0 pelo método Wang de classificação bayesiana (PRUESSE et al., 2007; WANG et al., 2007), utilizando um limiar de confiança (bootstrap) de no mínimo 80\% para atribuição de uma sequência à um grupo taxonômico (Kozich et al., 2013). As análises da composição taxonômica das comunidades estudadas foram feitas ao nível de filo, família e, por fim, gênero. 


\section{RESULTADOS E DISCUSSÃO}

\subsection{Mecanismos de adaptação térmica de Exiguobacterium antarcticum}

\subsubsection{Culturas bacterianas}

As culturas bacterianas cultivadas a $0{ }^{\circ} \mathrm{C}$ e a $37^{\circ} \mathrm{C}$ tiveram um perfil de crescimento bastante distinto. Partindo de um inóculo de densidade ótica (DO) igual a $0,045(600 \mathrm{~nm})$, as culturas a $37^{\circ} \mathrm{C}$ atingiram a fase exponencial rapidamentede DO entre 0,4 e $0,5(600 \mathrm{~nm})$, após cerca de 4 horas. Quando cultivadas a $0{ }^{\circ} \mathrm{C}$ as bactérias se mantiveram oir 7 dias em Fase Lag até o início do aumento do número de células e início da fase Log após 12 dias de incubação. As curvas de crescimento a $0^{\circ} \mathrm{C}$ e $37^{\circ} \mathrm{C}$ são mostradas nas figuras 16 e 17 , respectivamente.

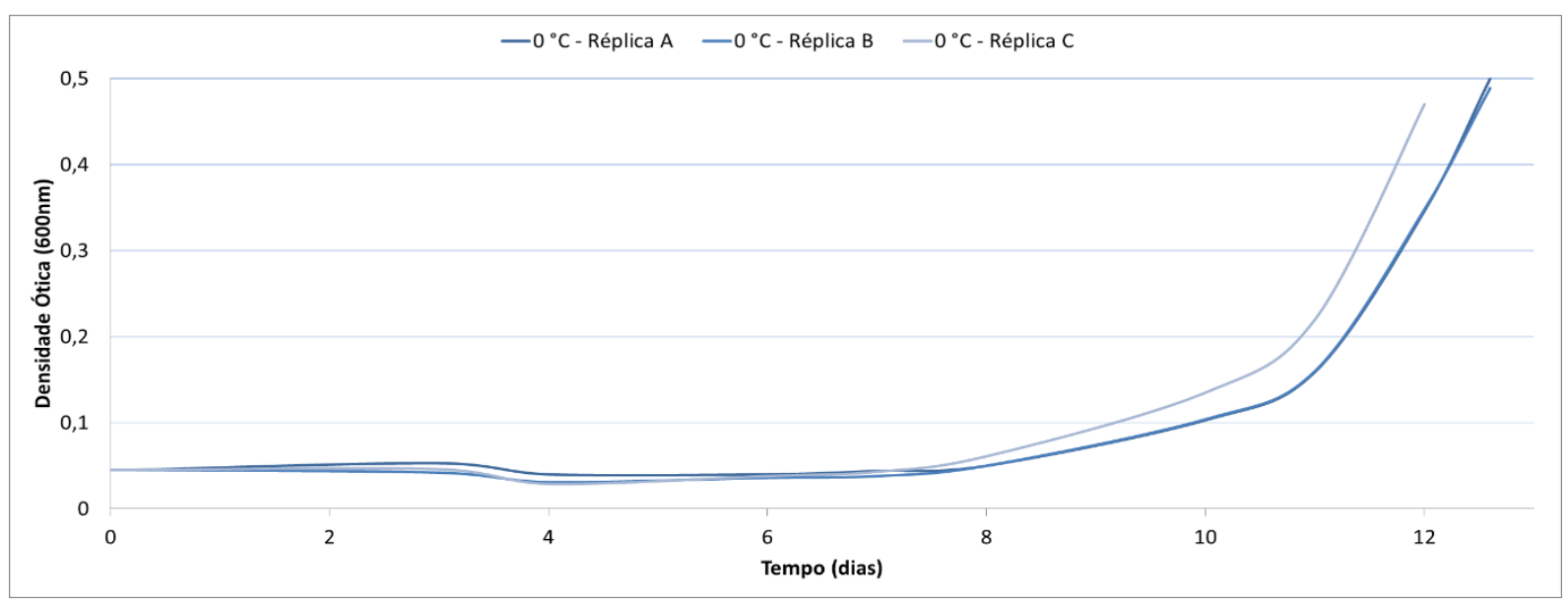

Figura 16 - Curva de crescimento de E. Antarcticum a $0 \stackrel{\circ}{\circ}$. Culturas em triplicata alcançaram uma densidade ótica de 0,45 após cerca de 12 dias.

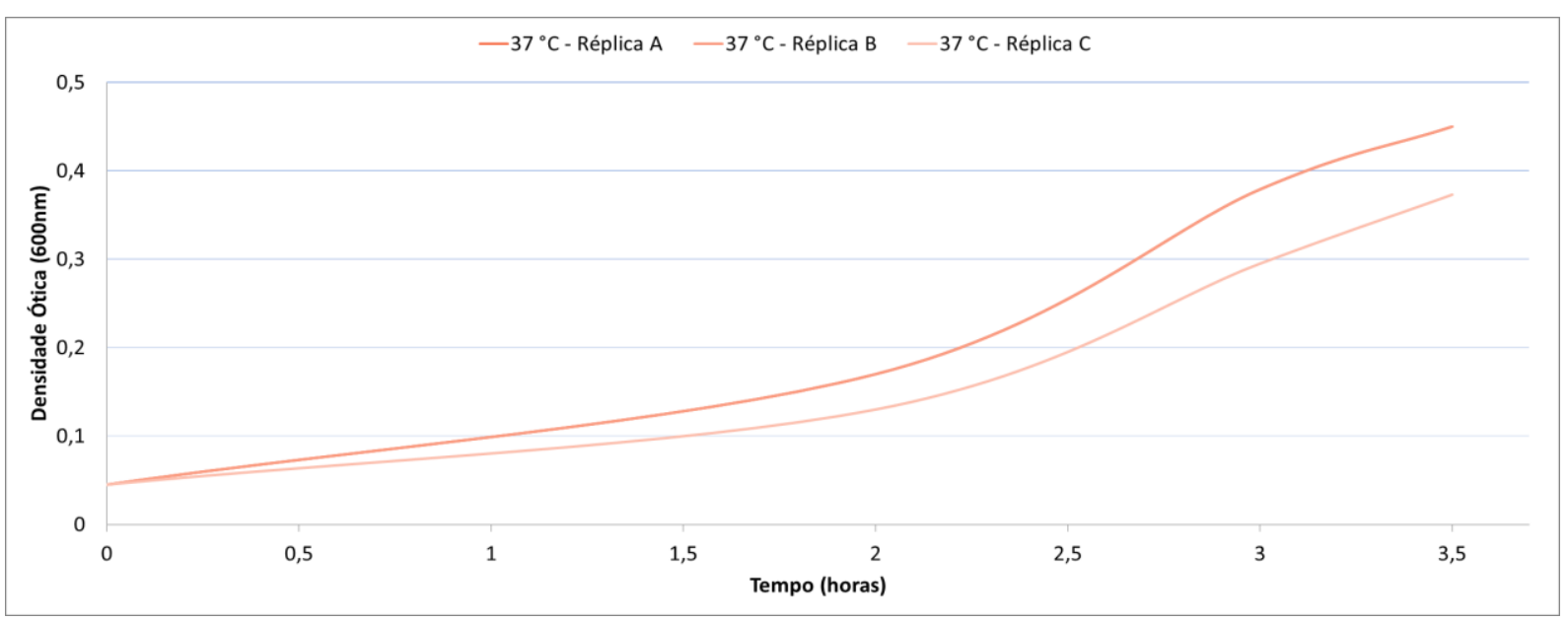

Figura 17 - Curva de crescimento de E. Antarcticum a $37^{\circ}$ C.Culturas em triplicata alcançaram uma densidade ótica de 0,45 após cerca de 3,5 horas. 
O período que antecedeu a fase log da curva de crescimento pode estar relacionado ao período necessário para que as múltiplas adaptações quanto à tradução e transcrição de genes, alterações responsáveis pela conformação espacial de proteínas e regulação de vias metabólicas ocorram, permitindo que o organismo possa prosperar em temperaturas sub-ótimas. As células crescendo a 0 ${ }^{\circ} \mathrm{C}$ possuem formato de bastões curtos ou com leve curvatura, a cultura a $37{ }^{\circ} \mathrm{C}$ apresenta células em formato de longos bastões temperaturas (Figuras 18 e 19). Estas diferenças fenotípicas, acompanhando o crescimento da bactéria em diferentes, observadas por microscopia de contraste de fase se mostraram significativas (Figura 19). Não foi observada mudanças quanto à motilidade das bactérias.
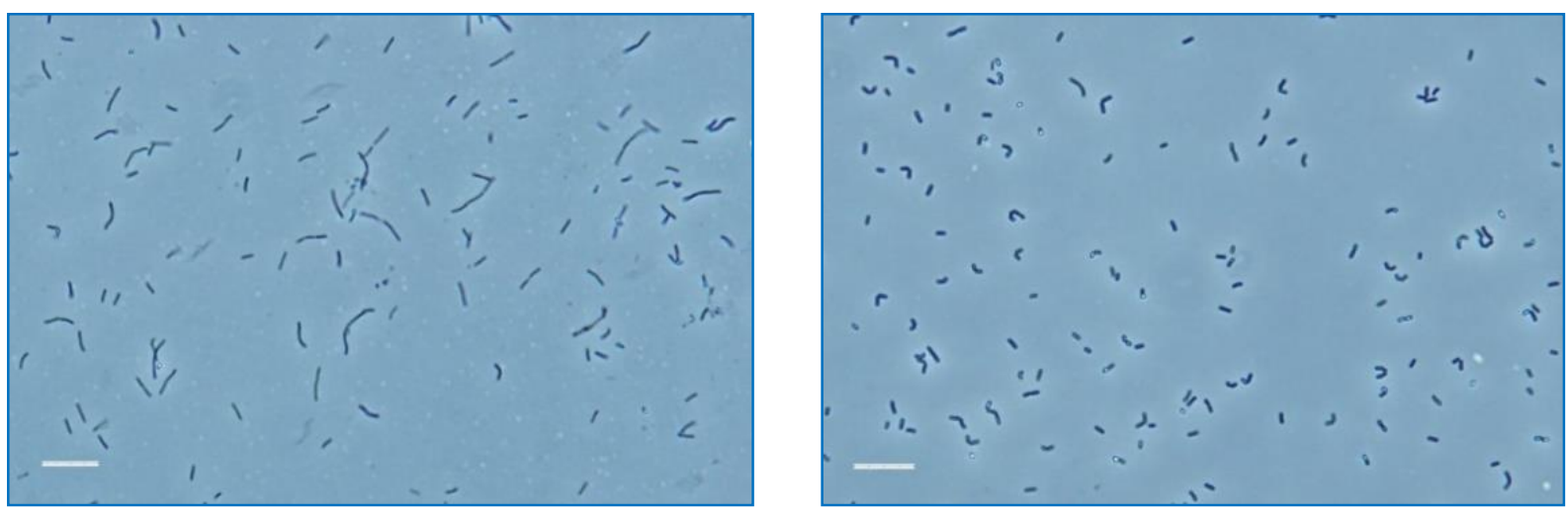

Figura 18 - Microscopia de contraste de fase. Exiguobacterium antarcticum cultivada, a $37^{\circ} \mathrm{C}$ e a $0{ }^{\circ} \mathrm{C}$, respectivamente. Barra de escala em branco correspondente a $20 \mu \mathrm{m}$.
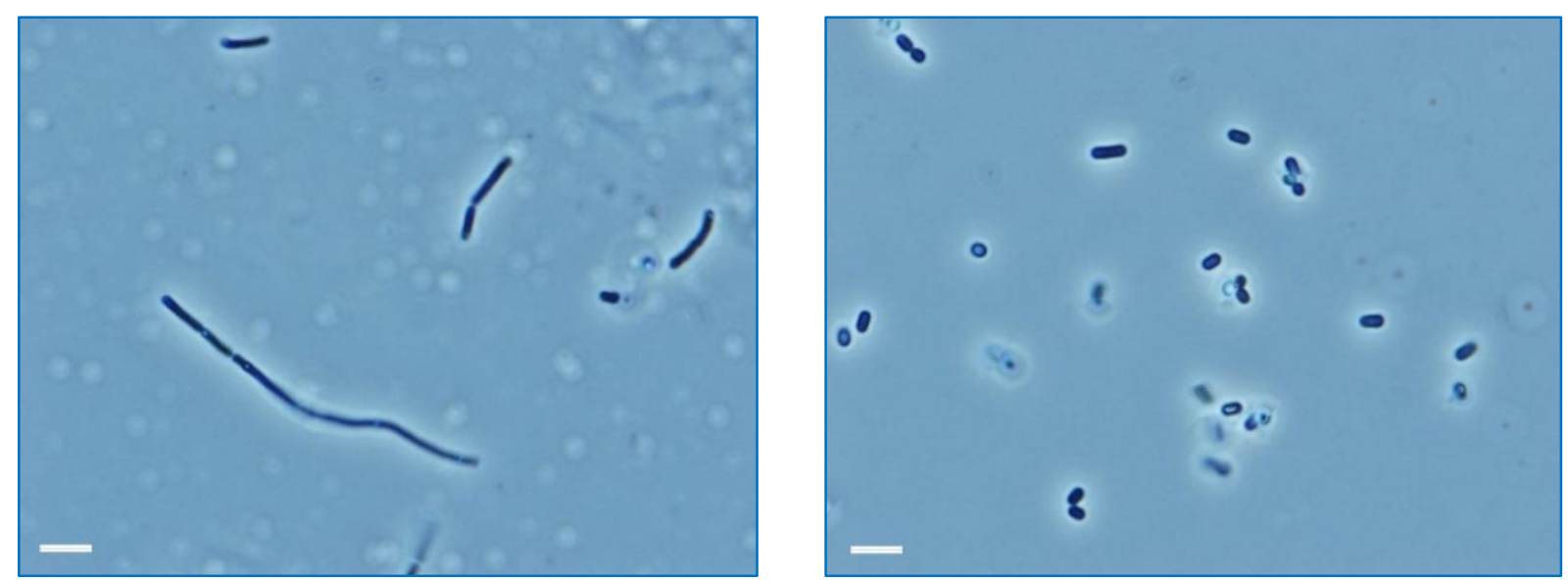

Figura 19 - Microscopia de contraste de fase. Exiguobacterium antarcticum cultivada, a $37^{\circ} \mathrm{C}$ e a $0{ }^{\circ} \mathrm{C}$, respectivamente. Barra de escala em branco correspondente a $5 \mu \mathrm{m}$. 


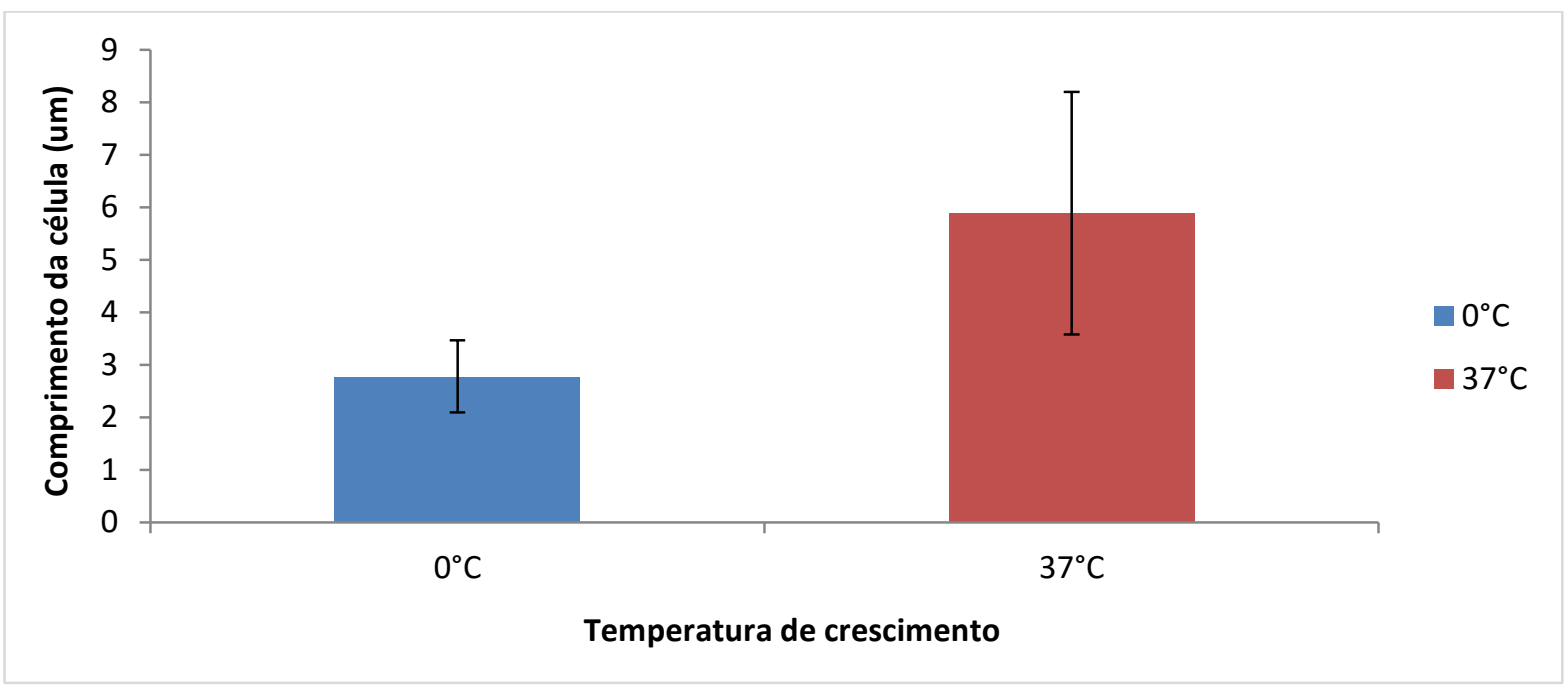

Figura 20 - Comprimento médio de células de $E$. antarcticum cultivadas, a $0{ }^{\circ} \mathrm{C}$ e a $37^{\circ} \mathrm{C}$.

A microscopia eletrônica de varredura (MEV) foi realizada a baixo vácuo, o que permite observar as células sem nenhum processo de fixação e as imagens das células cultivadas nas duas temperaturas é mostrado nas figuras 21 e 22. Apesar do benefício de se estudar células de uma cultura fresca, esta técnica pode deixar as células com formato achatado pois os líquidos intracelulares volatizam no vácuo. Além dos bastões mais longos, as células cultivadas a $37^{\circ} \mathrm{C}$ apresentaram estruturas similares à endósporos. Essas estruturas já haviam sido observadas empregando-se a microscopia de contraste de fase. Esses indícios de uma estrutura similar a endósporos contradiz a literatura acerca de $E$. antarcticum, já que outras linhagens dessa espécie foram descritas como não esporulantes, assim como outras espécies do mesmo gênero (CHATURVEDI et al., 2008; CHATURVEDI; SHIVAJI, 2006; FRUHLING et al., 2002). 


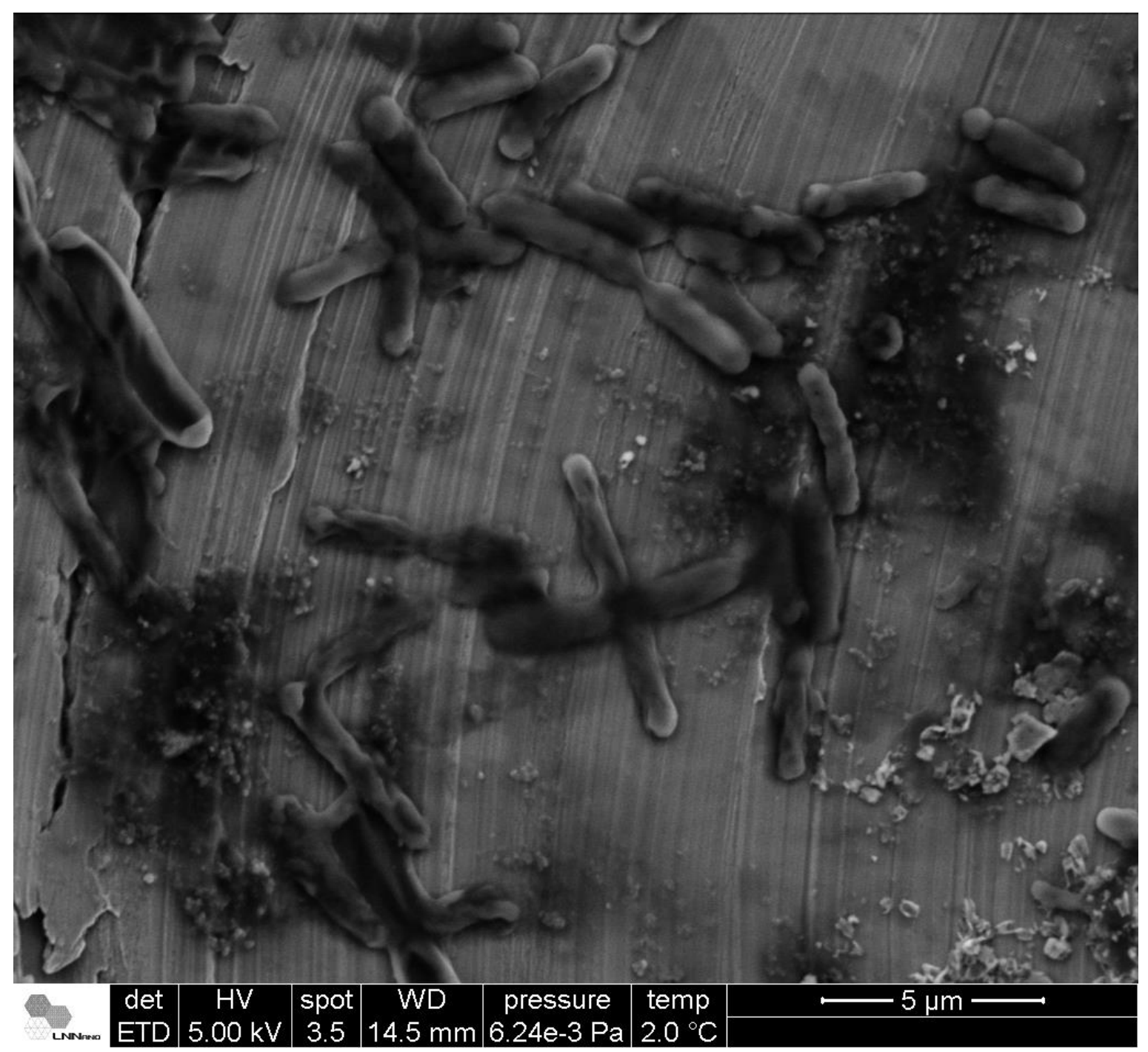

Figura 21 - Exiguobacterium antarcticum a $37^{\circ} \mathrm{C}$. Microscopia eletrônica de varredura ambiental. Barra de escala em branco correspondente a $5 \mu \mathrm{m}$. 


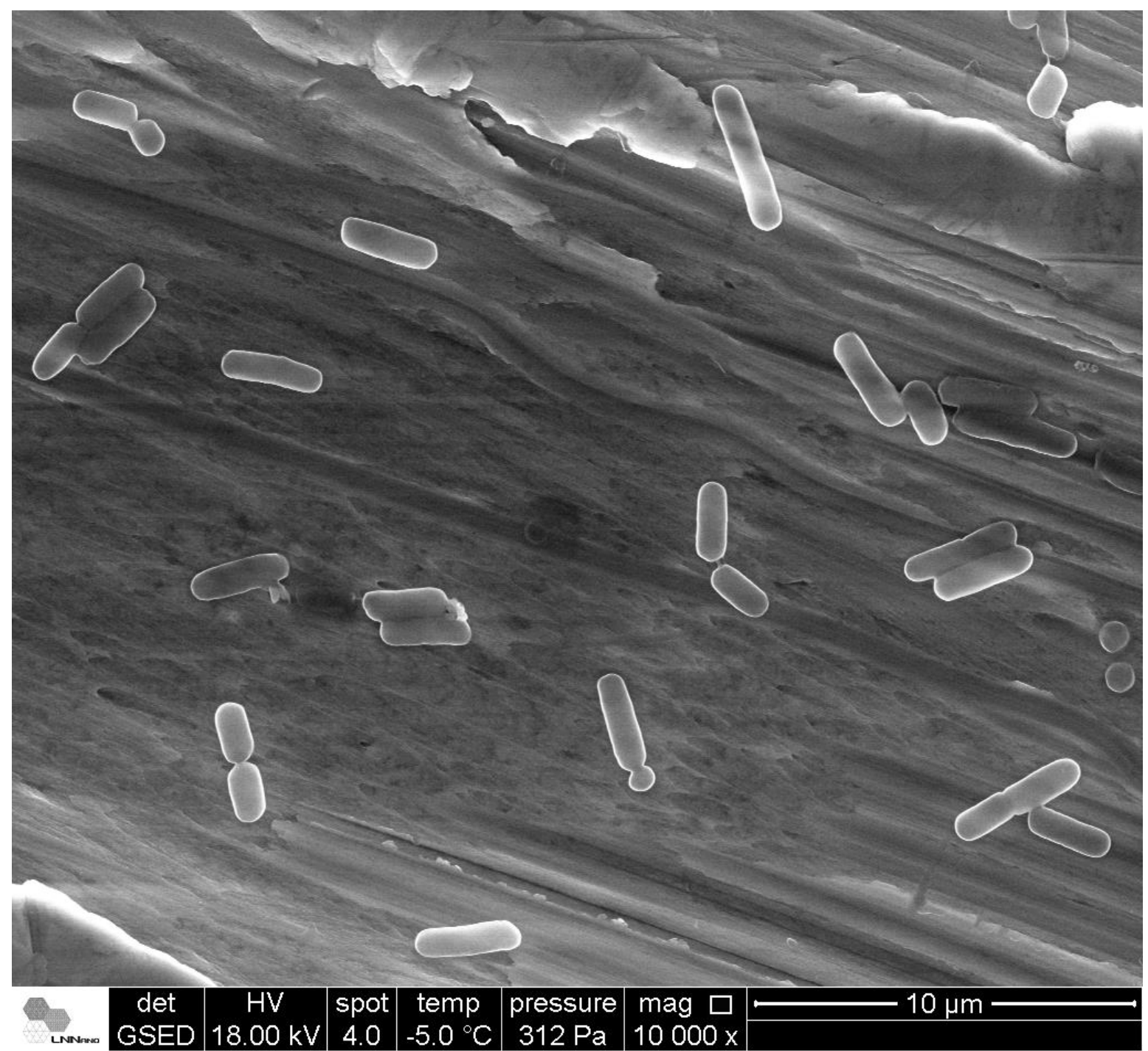

Figura 22 - Exiguobacterium antarcticum a $0{ }^{\circ} \mathrm{C}$. Microscopia eletrônica de varredura ambiental. Barra de escala em branco correspondente a $10 \mu \mathrm{m}$.

O pigmento que resulta nas colônias alaranjadas de E. Antarcticum B7 foi estudado através da técnica de espectrometria Raman. Os espectros foram obtidos de colônias cultivadas à temperatura ambiente, sem processos de fixações. $O$ espectro obtido é mostrado na figura 23. Os picos observados por volta de 1150 e $1520 \mathrm{~cm}^{-1}$ correspondem ao espectro esperado para pigmentos da classe dos carotenoides (DE OLIVEIRA et al., 2010; PULSCHEN et al., 2015). Carotenoides têm sido caracterizados por seu papel foto protetor e antioxidante, e sua presença é frequente em isolados provenientes da Antártica. Além disso, biopigmentos também têm sido estudados como um possível indicador de vida fora da Terra, já que possuem bioassinaturas bastante específicas. A técnica de espectrometria Raman é exclusiva para análises in situ, o que exclui sua utilização para detecção de bioassinaturas em 
planetas extra-solares, mas tem sido considerada em missões com sondas robóticas futuras.

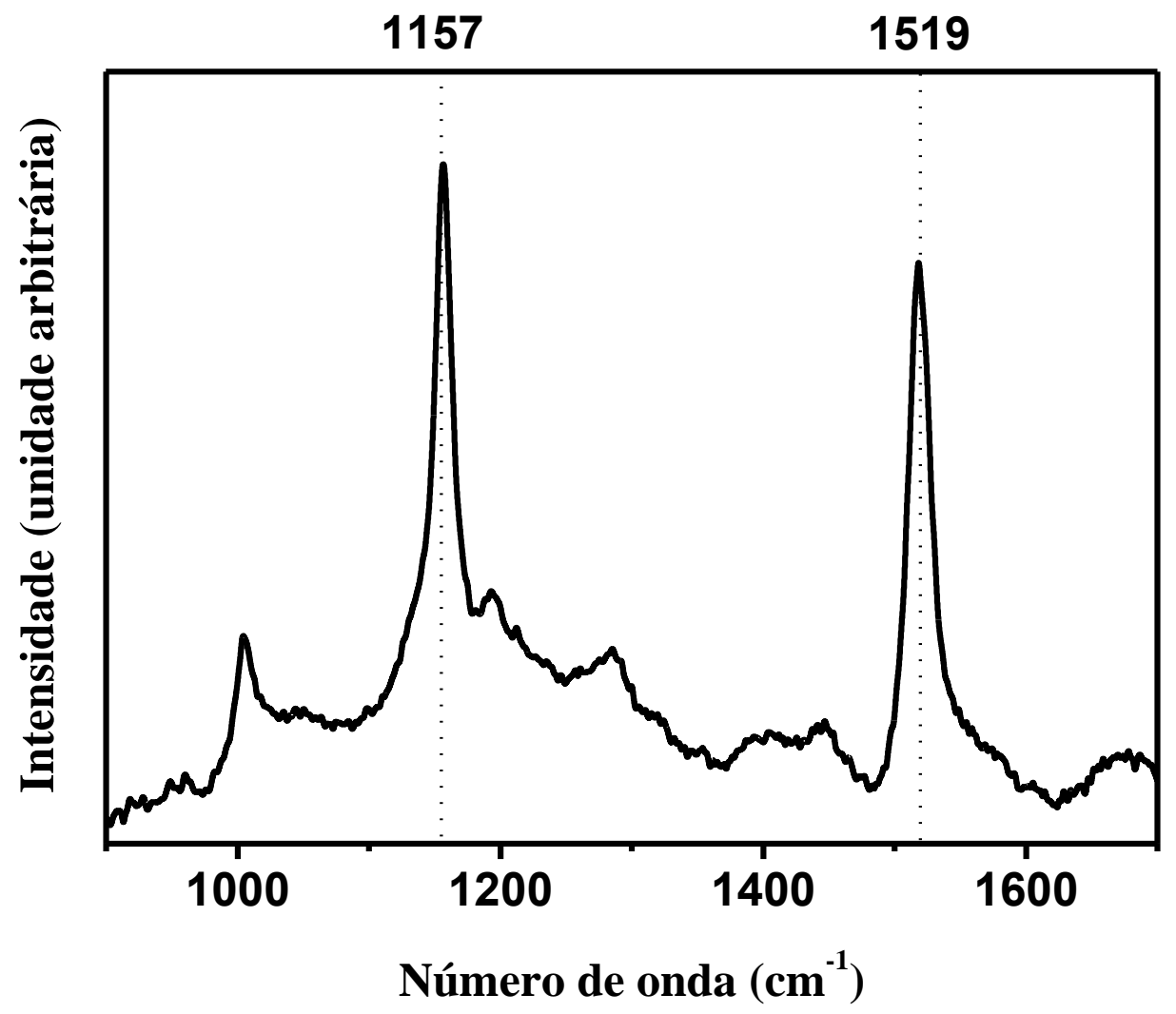

Figura 23- Espectro Raman de Exiguobacterium antarcticum, mostrando o sinal intenso e característico da presença de carotenoides. (Duas bandas intensas próximas de 1150 e $1520 \mathrm{~cm}^{-1}$ )

\subsubsection{Proteoma diferencial de E. antarcticum}

O perfil proteico de E. Antarcticum B7, obtido por 2D PAGE (figura 24 e 25) revelou um padrão semelhante aos descritos para outras bactérias, com a maioria dos pontos de alto peso molecular concentrados na faixa de $\mathrm{pH}$ ácido do gel nas duas situações de cultivo testadas. De 320 a 454 pontos foram detectados nos géis 2-D distribuídos na faixa de pl entre 3,5 e 10,5 e massa molecular entre 10 e 95 kDa. 


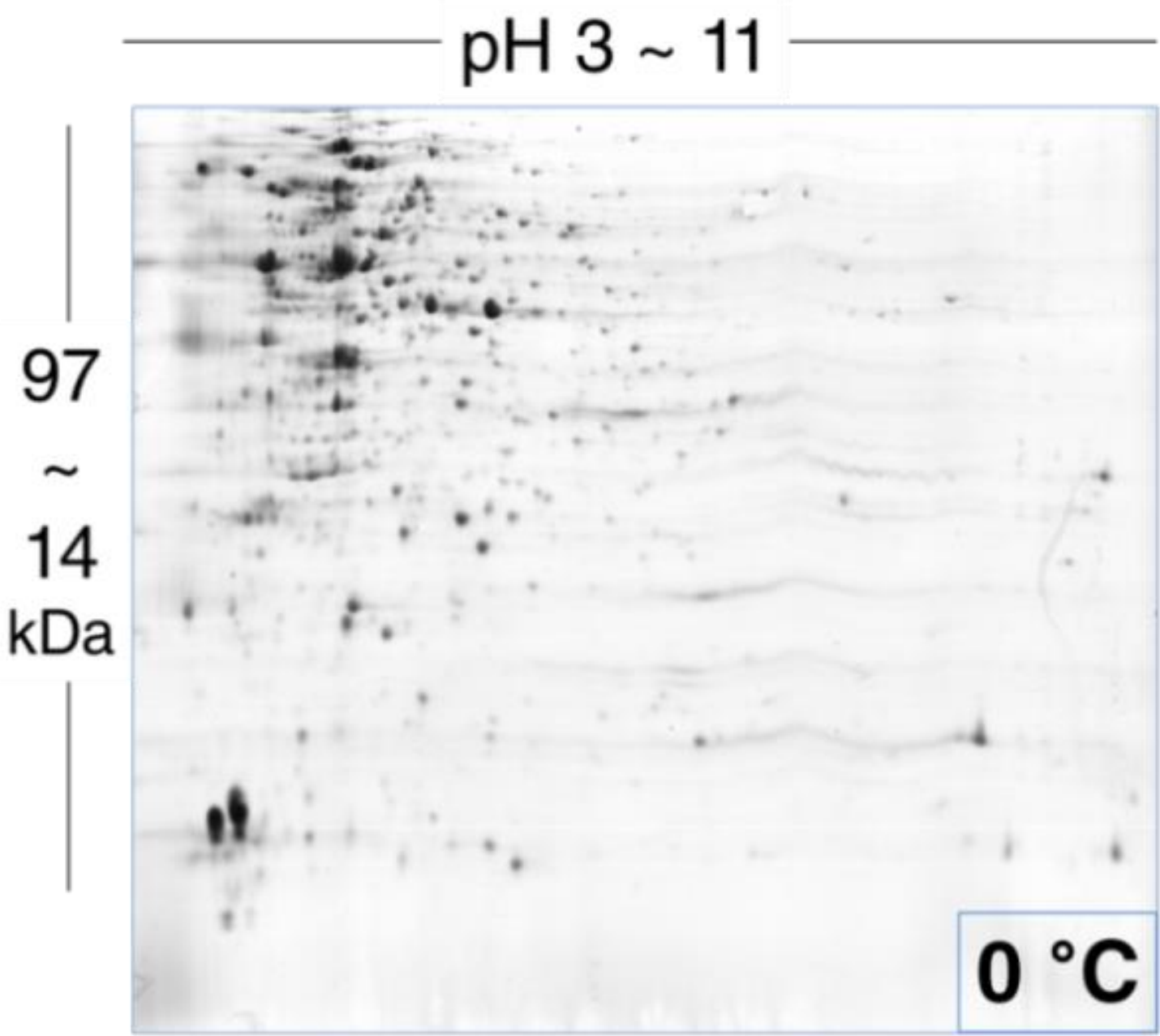

Figura 24 - Gel de eletroforese de 2 dimensões corados com azul de coomassie coloidal mostrando o perfil de expressão proteica de $E$. antarcticum em culturas de $0{ }^{\circ} \mathrm{C}$. 
$\mathrm{pH} 3 \sim 11$

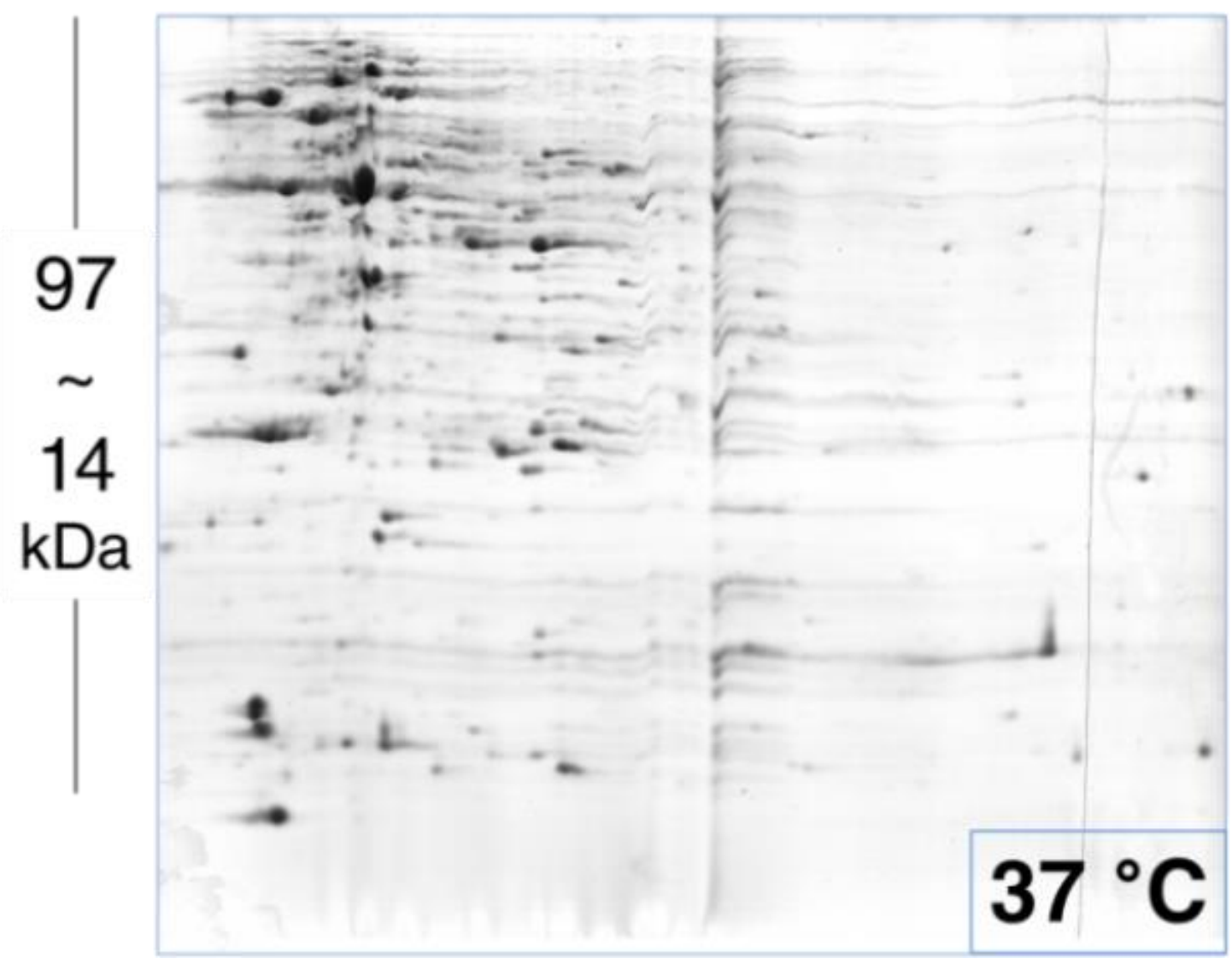

Figura 25 - Gel de eletroforese de 2 dimensões corados com azul de coomassie coloidal mostrando o perfil de expressão proteica de E. antarcticum $\mathrm{B} 7$ em culturas de $37^{\circ} \mathrm{C}$.

Análise por 2D-DIGE detectou 73 spots, representando proteínas diferencialmente expressas entre $0{ }^{\circ} \mathrm{C}$ e $37^{\circ} \mathrm{C}$ (figura 26), dos quais 48 foram reprimidos à $0{ }^{\circ} \mathrm{C}$ enquanto 25 foram regulados positivamente. 
$\mathrm{pH} 3 \sim 11$

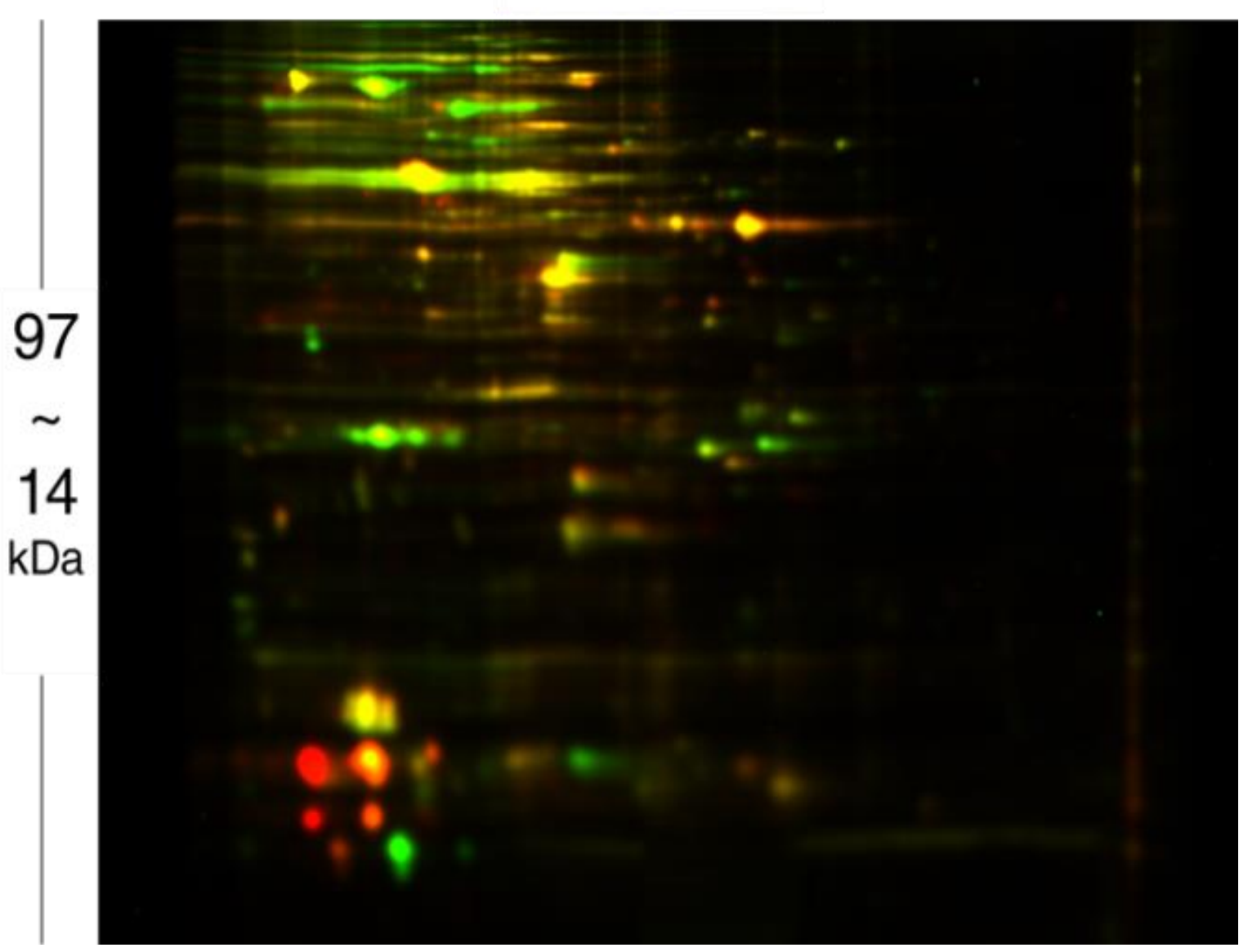

Figura 26 - Gel de expressão diferencial (2D-DIGE) mostrando em vermelho os spots correspondentes às proteínas expressas a $0{ }^{\circ} \mathrm{C}$ e em verde spots correspondentes às proteínas expressas a $37^{\circ} \mathrm{C} . \mathrm{A}$ faixa de $\mathrm{pH}$ em que as proteínas estão distribuídas é mostrada acima

As proteínas presentes nesses spots foram recuperadas do gel de poliacrilamida sendo que 25 delas foram identificados com sucesso por espectrometria de massas (MS/MS), correspondendo a 13 proteínas diferentes mostradas na tabela 2. Algumas dessas proteínas correspondem a genes conservados no genoma de E. antarcticum, e em sua maioria possuem histórico de relevância quanto à mecanismos de adaptação térmica, tais como os genes que codificam as cold shock proteins, as quais foram 32 vezes mais expressas a $0{ }^{\circ} \mathrm{C}$ do que a $37^{\circ} \mathrm{C}$ neste estudo (CARNEIRO et al., 2012).

Algumas proteínas com a mesma identidade obtida por espectrometria de massas, foram encontradas em diferentes pontos do gel exibindo diferentes padrões de dispersão, uma característica que indica que sofreram diferentes modificações póstraducionais (ROGOWSKA-WRZESINSKA et al., 2013). 
Tabela 2 - Proteínas expressas diferencialmente em E. antarcticum B7 identificadas por MS/MS: nome da proteína e gene correspondente ao genoma anotado, número de acesso no $\mathrm{NCBI}$, abundancia relativa nas duas temperaturas e ponto isoelétrico em relação ao peso molecular da proteína.

\begin{tabular}{|c|c|c|c|c|c|}
\hline Nome da proteína & Gene & Protein accession & $\mathrm{RV} 0^{\circ}$ & RV $37^{\circ}$ & Thoretical pl / MW \\
\hline Cold shock protein & $\operatorname{cspC1}$ & 407477389 & 2,75717 & $-2,75717$ & 4,55 / 7395 \\
\hline Cold shock protein & $\operatorname{cspC} 1 / 2$ & 407477390 & 32,3498 & $-32,3498$ & $4,41 / 7395$ \\
\hline Cold shock protein & $\operatorname{cspC} 1$ & 407477389 & 4,34151 & $-4,34151$ & 4,55 / 7395 \\
\hline Cold shock protein & $\operatorname{cspC} 1$ & 407477389 & 3,13348 & $-3,13348$ & 4,55 / 7395 \\
\hline Peroxiredoxina & - & 407478620 & $-3,95331$ & 3,95331 & 4,58 / 20756 \\
\hline Peroxiredoxina & - & 407478620 & $-2,6502$ & 2,6502 & 4,58 / 20756 \\
\hline Peroxiredoxina & - & 407478620 & $-2,96454$ & 2,96454 & 4,58 / 20756 \\
\hline Peroxiredoxina & - & 407478620 & $-2,55163$ & 2,55163 & 4,58 / 20756 \\
\hline Chaperona htpG & htpG & 407478603 & $-5,07356$ & 5,07356 & 4,85 / 71438 \\
\hline Chaperona htpG & htpG & 407478603 & $-4,96707$ & 4,96707 & $4,85 / 71438$ \\
\hline Chaperona htpG & htpG & 407478603 & $-3,57536$ & 3,57536 & $4,85 / 71438$ \\
\hline Chaperona htpG & htpG & 407478603 & $-10,9631$ & 10,9631 & $4,85 / 71438$ \\
\hline Chaperona htpG & htpG & 407478603 & $-7,77555$ & 7,77555 & 4,85 / 71438 \\
\hline Chaperona DnaK & dnaK & 407476630 & $-4,67413$ & 4,67413 & 4,69 / 64920 \\
\hline Superóxido dismutase & $\operatorname{sod} A$ & 407476703 & $-2,12835$ & 2,12835 & 5,38 / 22525 \\
\hline 60 kDa Chaperonina & groL & 407478394 & $-4,78452$ & 4,78452 & $4,81 / 57899$ \\
\hline Fator de elongação G & fusA & 407475990 & $-2,64384$ & 2,64384 & $4,91 / 76387$ \\
\hline Proteína GrpE & grpE & 407476629 & $-2,36734$ & 2,36734 & 4,47 / 21074 \\
\hline Proteína GrpE & grpE & 407476629 & $-5,72596$ & 5,72596 & 4,47 / 21074 \\
\hline 10 kDa Caperonina & gros & 407478395 & $-4,02516$ & 4,02516 & $5,11 / 10048$ \\
\hline 1-Fosfofrutoquinase & fruK & 407476901 & $-2,49208$ & 2,49208 & 4,67 / 32964 \\
\hline NADH: flavina oxidoredutase & yqiG & 407478474 & 4,20739 & $-4,20739$ & 4,69 / 40299 \\
\hline NADH: flavina oxidoredutase & yqiG & 407478474 & 2,40574 & $-2,40574$ & 4,69 / 40299 \\
\hline Periplasmic solute biding protein & - & 407478380 & 3,4655 & $-3,4655$ & 4,82 / 33929 \\
\hline Proteína Hipotética Eab7_2007 & - & 407477844 & $-4,06966$ & 4,06966 & 5,42 / 23600 \\
\hline
\end{tabular}

Também com a comparação dos dados obtidos a partir da anotação do genoma, E. Antarcticum B7 mostrou possuir seis genes que codificam os homólogos das principais cold-shock proteins. Dentre as proteínas expressas diferencialmente duas delas, Csp1 e Csp2, foram identificadas por MS/MS em níveis mais elevados de expressão a $0{ }^{\circ} \mathrm{C}$, sendo Csp1 a mais abundante entre elas, indicando sua marcada relevância para a adaptação celular ao frio.

Em relação ao choque térmico, o que é geralmente proposto, é que uma mudança de temperatura do ponto ótimo de crescimento ao mínimo que a bactéria consegue crescer, dentro de alguns minutos, constitui um choque térmico (WEBER; MARAHIEL, 2003).

Em contrapartida, proteínas relacionadas ao estresse por temperaturas elevadas foram mais expressas a $37^{\circ} \mathrm{C}$. As proteínas HtpG e DnaK fazem parte de 
uma família de proteínas que compartilham o domínio HSP90 e HSP70, respectivamente (heat shock protein $90 \mathrm{kDa}$ e $70 \mathrm{kDa}$ ). Essas moléculas atuam como chaperonas e possuem distribuição taxonômica bastante ampla (CSERMELY et al., 1998).

Enzimas envolvidas no combate ao estresse oxidativo, tais como peroxiredoxina e superóxido dismutase, foram reprimidas a $0 \stackrel{\circ}{ } \mathrm{C}$ em comparação com $37^{\circ} \mathrm{C}$. Com a análise do transcriptoma diferencial de E. antarcticum, desenvolvido em paralelo com o presente estudo, foi também observada a repressão da rota metabólica envolvendo o complexo citocromo c oxidase, responsável pela via final no mecanismo de fosforilação oxidativa (BARBOSA, 2012). Em Bacillus subtillis, também da família Bacillaceae, observou-se a repressão do metabolismo aeróbico em 0 ㄷ em comparação com temperaturas mais quentes juntamente com a redução global das taxas metabólicas exibidas por células em ambientes frios. A redução do metabolismo aeróbico acarreta na redução de concentrações de radicais superóxido e de espécies reativas de oxigênio que são produzidos durante a fosforilação oxidativa, justificando a redução do níveis intracelulares de peroxiredoxina e superóxido dismutase (BUDDE et al., 2006).

\subsection{Resistência de E. antarcticum B7 e P. halocryophilus OR1 aos ambientes simulados}

\subsubsection{Resistência à dessecação em E. Antarcticum B7}

Para testar o efeito dos solutos no potencial de resistência à dessecação em $E$. Antarcticum, células bacterianas foram dessecadas em $\mathrm{H}_{2} \mathrm{O}$, tampão PBS e TSB. Duas condições foram experimentadas: dessecação em dessecador de sílica (Umidade Relativa 4\%) e em liofilizador (Umidade Relativa $\sim 0 \%$ ). Foi demonstrada que a presença de certos carboidratos como a trehalose e outras moléculas complexas pode proteger as células bacterianas dos efeitos nocivos da anidrobiose (FRANCA; PANEK; ELEUTHERIO, 2007). No entanto, seria ideal observar a resistência inata da bactéria, seca em $\mathrm{H}_{2} \mathrm{O}$, uma vez que a presença de outros solutos pode interferir nos testes subsequentes de sobrevivência em ambientes simulados (LIMA, 2010). Foi observado uma redução de cerca de 10 vezes na viabilidade de $E$. antarcticum quando seca em $\mathrm{H}_{2} \mathrm{O}$ quando comparado a PBS e TSB. No entanto, não foi possível quantificar eficientemente essa diferença devido ao número muito grande 
de unidades formadores de colônias em cada placa ao seguir a metodologia descrita. Um novo experimento deverá ser realizado, acrescentando diluições seriadas às bactérias ressuspensas de forma a garantir um número razoável de colônias por placa. Interessante também notar que não foram observadas diferenças aparentes quanto a viabilidade de células quando secas em dessecador ou em liofilizador.

\subsubsection{Resistência à radiação solar terrestre}

Os experimentos de irradiação UV com Simulador Solar foram realizados para verificar a sensibilidade das células desidratadas dos psicrotróficos Exiguobacterium antarcticum B7 e Planococcus halocryophilus OR1 à um perfil de radiação UV-A e UVB similar ao que atinge a superfície da Terra pela luz solar. A radiação UV-C é completamente absorvida pela atmosfera da Terra e não é produzida pelo Simulador Solar. Deinococcus radiodurans tem sido bastante estudada quanto ao seu potencial de resistência à radiação ionizante e não ionizante, em células hidratadas sendo usada como referência em experimentos de simulação de ambientes extraterrestres envolvendo bactérias psicrotróficas e psicrófilas.

Células de $E$. antarcticum e $P$. halocryophilus irradiadas com simulador solar $(\lambda$ $>280 \mathrm{~nm}$ ) mostraram um perfil de baixa resistência à radiação UV-A e UV-B. $D$. radiodurans teve sua sobrevivência reduzida pela metade já na dose de $10 \mathrm{~J}^{-\mathrm{m}^{-2}}$ e foi completamente inativada com doses a partir de $30 \mathrm{~J} . \mathrm{m}^{-2}$ (Figura 27).

As Radiações UVA e UVB são classificadas como radiações não ionizantes (NIR), ou seja, que não possuem energia para produzir íons carregados quando passam através da matéria. No entanto, NIRs podem interagir com as células desidratadas através da geração de ruptura direta de ligações covalentes nas moléculas de DNA (UTSUMI; ELKIND, 1979). 


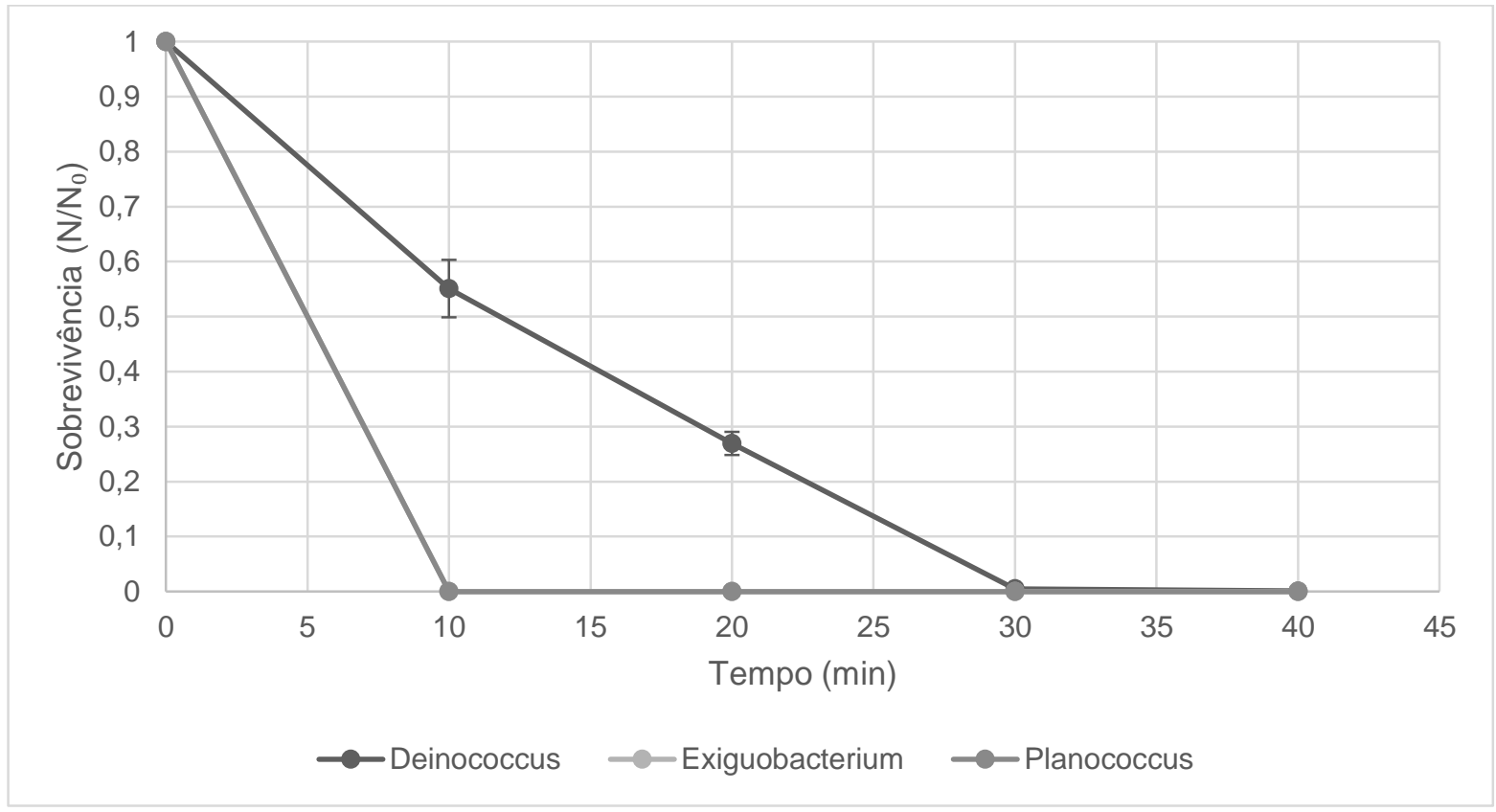

Figura 27 - Curvas de sobrevivência de Deinococcus radiodurans, Exiguobacterium antarcticum e Planococcus halocryophilus expostas à radiação ultravioleta ambiental $(\lambda>280 \mathrm{~nm})$.

4.2.3 Resistência às condições interplanetárias e à superfície de Marte

Os experimentos de irradiação realizados no LNLS visaram quantificar os efeitos da radiação ultravioleta de vácuo (UV-V), e da ausência de pressão atmosférica, características do espaço interplanetário. Ao contrário das radiações UVA e UVB, a radiação UV-V é altamente ionizante. O resultado é mostrado na figura 28. Foi observada uma rápida inativação de E. Antarcticum, com redução de cerca de

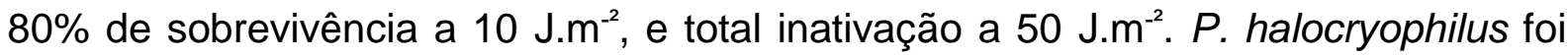
completamente inativa somente a partir de $500 \mathrm{J.m}^{-2}$. No entanto, é importante ressaltar que esse experimento ainda precisa ser repetido, com doses distribuídas na faixa de 0 500 J.m² e com um maior número de amostras irradiadas, no intuito de diminuir o desvio nos pontos encontrados neste primeiro ensaio e buscar uma curva de sobrevivência que mais claramente relacione sobrevivência com dose de radiação UV-V. 


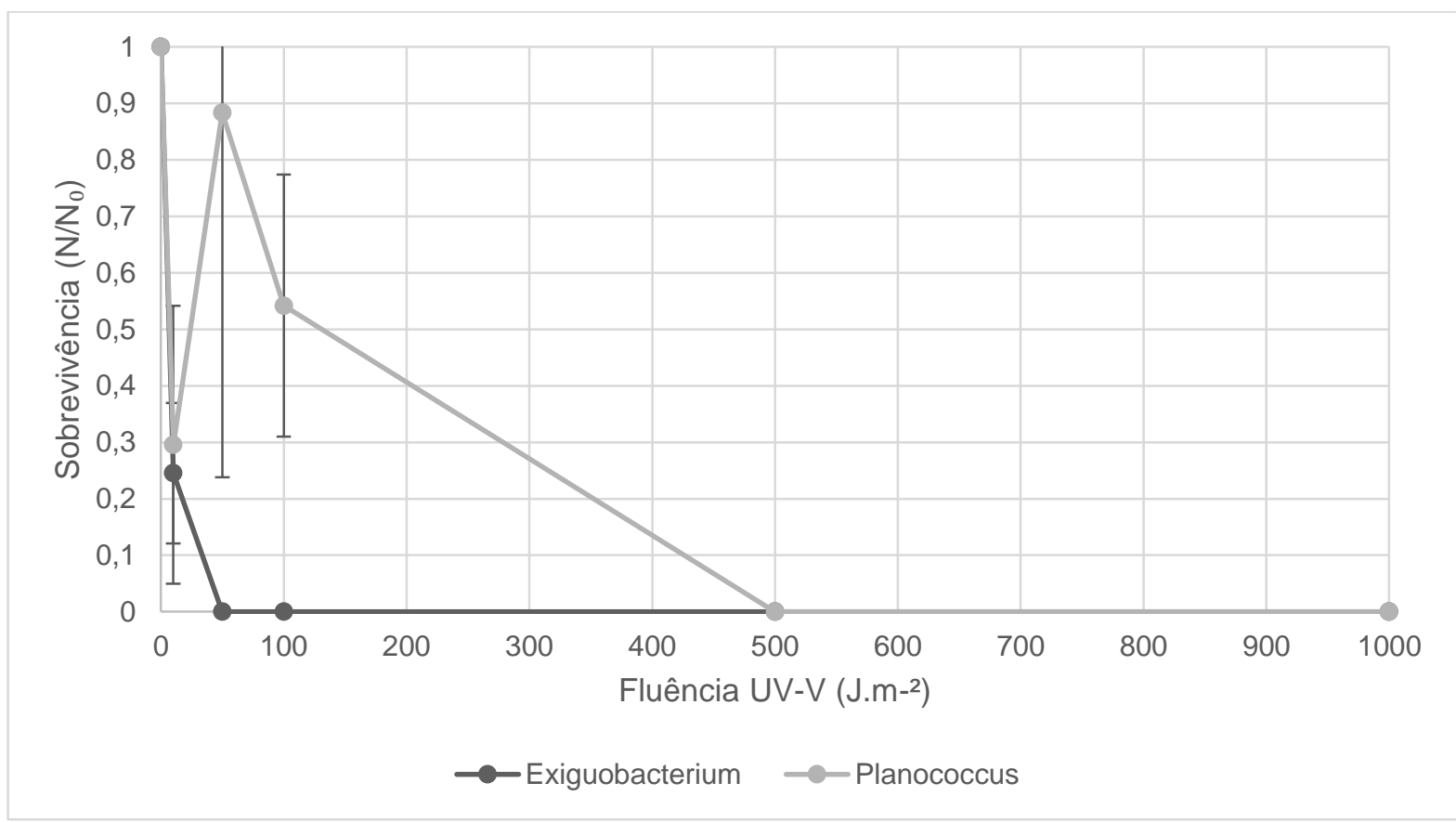

Figura 28 - Curvas de sobrevivência de Exiguobacterium antarcticum e Planococcus halocryophilus mostrando os efeitos da radiação da linha de luz TGM do LNLS $(\lambda>57,47 \mathrm{~nm})$ em câmara de vácuo.

Nos primeiros ensaios realizados na câmara de simulação de ambientes extraterrestres, buscando simular as condições da superfície de Marte, não foi possível traçar uma relação entre sobrevivência e dose de radiação visto que $E$. antarcticum, $D$. radiodurans e $P$. halocryophilus se mostraram sensíveis à combinação de baixa pressão, baixa temperatura e atmosfera simulada de Marte. Durante esses primeiros experimentos, no entanto, as bactérias desidratadas foram submetidas a dois choques de temperatura, tanto ao entrar na câmara aonde a temperatura testada foi de $-20 \stackrel{\circ}{\circ}$, quanto na retirada das amostras voltando para a temperatura ambiente de $25 \stackrel{\circ}{ } \mathrm{C}$. Ao voltar à umidade ambiente, as amostras dessecadas e resfriadas, sofrem também um processo de rápido descongelamento e reidratação. Dentro do gênero Exiguobacterium, os efeitos do processo de descongelamento e recongelamento foram testados por Vishnivetskaya (2007) e se mostraram deletérios. Portanto, o próximo passo a continuidade dos estudos seria testar a sobrevivência das três espécies de bactérias a pressão e atmosfera de Marte, em diferentes temperaturas. Futuramente, será interessante comparar o potencial de sobrevivência a ambiente extraterrestres de $E$. antarcticum com o de outras bactérias resistentes a anidrobiose isoladas neste estudo.

Também seria proveitoso comparar os resultados encontrados na câmara de simulações espaciais de projeto brasileiro com os dados de experimentos 
desenvolvidos em outros países que possuem equipamentos semelhantes. Recentemente foi descrita a sensibilidade à radiação e à dessecação do psicrotrófico Psychrobacter também em simulação da superfície de Marte (SMITH, D. J. et al., 2009); experimentos relacionando a inativação de linhagens pertencente ao gênero Bacillus sob diferentes doses de radiação UV de perfil similar a Marte realizados na Flórida (EUA) mostraram que existem diferenças no potencial de tolerância à radiação dentro de espécies pertencentes ao mesmo gênero (SCHUERGER et al., 2006); e na Universidade de Aarhus, Dinamarca um estudo comparando o efeito de condições marcianas em comunidades de permafrost mostrou que enquanto a radiação ultra violeta é o fator mais nocivo em relação a viabilidade celular na superfície da amostra, ciclos de congelamento e descongelamento afetam as células presentes em camadas internas (HANSEN et al., 2009).

Com à versatilidade fisiológica demonstrada por micro-organismos psicrófilos e pelo proteoma diferencial de E. antarcticum, é possível que encontremos capacidades de adaptação diferentes, dependendo da combinação de configurações ambientais que o organismo é submetido. Essa possibilidade deverá ser explorada no futuro em experimento de sobrevivência, aprofundando os resultados obtidos. Em um segundo momento, será possível investigar como condições ambientais extremas afetam esta bactéria e outros isolados polares.

\subsection{Prospecção de psicrotróficos resistentes à dessecação em ambientes polares}

\subsubsection{Isolamento e seleção de colônias}

As amostras de solo foram tratadas com clorofórmio, com a finalidade de mimetizar a pressão exercida pela dessecação por períodos prolongados de tempo (NARVAEZ-REINALDO et al., 2010). Posterior ao tratamento do solo e inoculação dos meios de cultura, foi detectada a presença de crescimento microbiano, de maneira dependente à proveniência da amostra do solo, meio de cultura e temperatura de incubação. A tabela 3 apresenta o resultado da presença de crescimento microbiano. 
Tabela 3 - Número de Unidades Formadoras de Colônias por grama de solo (UFC.g $g^{-1}$ ) isoladas de amostras de solo tratadas com clorofórmio.

\begin{tabular}{lcccc}
\hline \multicolumn{1}{c}{ Amostra } & TSA 5 C & TSA 30 C & R2A 5 C & R2A 30 C \\
\hline Deception Ponto 85 & $<0$ & 33 & $<0$ & $<0$ \\
Deception Ponto 86 & $<0$ & $<0$ & $<0$ & $<0$ \\
Deception Ponto 92 & $<0$ & 606 & $<0$ & $<0$ \\
Baranowski Ponto 01 & $<0$ & 472 & $<0$ & $<0$ \\
Baranowski Ponto 06 & $<0$ & $<0$ & $<0$ & $<0$ \\
Baranowski Ponto 12 & 568 & $<0$ & $<0$ & $<0$ \\
Axel Heiberg superfície & 173 & 126 & 13 & 40 \\
Axel Heiberg interface & 693 & 186 & 66 & 126 \\
Axel Heiberg permafrost & 546 & 320 & 53 & 53 \\
\hline
\end{tabular}

Nas amostras do solo de Deception foram obtidos apenas isolados mesofílicos, não foi obtido o crescimento de colônias a $5 \stackrel{\circ}{\circ}$. A llha Deception é um vulcão ativo cuja caldeira é inundada pelo mar estando a cerca de $160 \mathrm{~m}$ de profundidade, e sua última erupção foi registrada em 1970 (BAKER; MCREATH, 1971). Esse local é considerado único pela mistura de características polares e geotérmicas. As amostras de solo estudadas fazem parte da borda da caldeira, amostras 85 e 86 , coletadas em temperatura de cerca de $40{ }^{\circ} \mathrm{C}$; e da borda do lago, amostra 92 , coletada a $9{ }^{\circ} \mathrm{C}$. Essa última amostra resultou em um número maior de UFC quando comparada às amostras de maior impacto geotérmico. No entanto, outros fatores a como composição química do solo, não abordada no presente estudo e bastante heterogênea na llha podem ter influência no resultado encontrado (DEHEYN et al., 2005).

Nas amostras de solos expostos pelo recuo da geleira Baranowski, também na Antártica, foram isoladas bactérias de duas amostras: do ponto 1, recentemente exposto pelo recuo de geleira; e do ponto 12 exposto pelo recuo de geleira a quase 4 décadas. Interessante notar que nesse último ponto houve o crescimento de isolados apenas na temperatura de $30 \stackrel{\circ}{ } \mathrm{C}$. Duarte (2010) mostrou que a comunidade microbiana exposta pelo recuo da geleira Baranowski passa por eventos de sucessão ecológica. A partir do momento em que as comunidades microbianas são expostas à 
atmosfera, ocorrem mudanças lentas e graduais na estrutura das comunidades nas próximas duas décadas. Novas mudanças foram observadas e correlacionadas com o acúmulo de potássio, magnésio e nitrogênio ao longo desse período.

Nas amostras de solo do Ártico (Axel-Heiberg) foi observado crescimento em ambos os meios de cultura, nas duas temperaturas de crescimento, indicando a presença de isolados psicrotolerantes e mesofílicos, com maior número de isolados cultivados à $5^{\circ} \mathrm{C}$ e em solos permanentemente congelados (permafrost).

Para o estudo de similaridade entre os isolados obtidos, as colônias de bactérias foram selecionadas randomicamente para análise empregando-se a técnica de Box-PCR foram utilizados para agrupar os isolados em filotipos (padrões de bandas singulares), evitando redundância de isolados selecionados para identificação e caracterização.

\subsubsection{Caracterização taxonômica dos isolados}

13 linhagens microbianas de filotipos singulares foram obtidos de amostras da Ilha Deception, 5 de Baranowski e 39 de Axel-Heiberg. Os 57 isolados tiveram seu gene 16S RNA amplificado. Cerca de 700 pb do gene foi sequenciado com o primer 27F e comparado com as sequências mantidas no banco de dados SILVA. A árvore filogenética inferida dos isolados é mostrada na figura 29.

As sequências de DNA identificadas mostraram uma prevalência de bactérias gram-positivas, cerca de $85 \%$ dos isolados possuem essa característica. A maioria desses isolados, 47 ao todo, pertence ao Filo Firmicutes e um ao Filo Actinobacteria. Esse resultado está de acordo com a literatura, que aponta que essas bactérias, embora não façam parte de um grupo monofilético, são maioria dentre as bactérias estudas que possuem resistência à anidrobiose (GARCIA, 2011).

O único grupo representado nos três locais que abrangem esse projeto é o da família Planococcaceae, filo Firmicutes. Dentro desta família encontram-se os isolados de Baranowski (ponto 12) de solo exposto pelo recuo de geleira desde a década de 70 e que sofreu eventos de mudanças geoquímicas e de sucessão ecológica descritos por (DUARTE, 2010). Esse estudo apontou também que existem diferenças claras quanto a composição microbiana do solo próximo à geleira em comparação com amostras mais distantes. O filo Firmicutes representou $2 \%$ da 
comunidade do solo 01 próximo à geleira e ainda menos abundantes nas amostras 06 e 12, em proporção menor do que 1\%. Interessante também notar que o Filo Proteobacteria que mostrou níveis de abundância de $20 \%$ nos solos próximos da geleira e cerca de $70 \%$ nos solos mais distantes, não foram isolados em nosso estudo de bactérias resistentes à dessecação. Planococcus halocryophilus, isolado do Ártico canadense e também foco do presente estudo, é um integrante da família Planococcaceae capaz de prosperar em temperaturas de até $-15^{\circ} \mathrm{C}$ e altas concentrações salinas (MYKYTCZUK; WILHELM; WHYTE, 2012). Há na literatura a descrição de outras cepas isoladas do Ártico, Antártica e, interessantemente, dos desertos gelados do Himalaia, Índia (MAYILRAJ et al., 2005). No entanto, não é de nosso conhecimento estudos descrevendo a capacidade de sobrevivência de integrantes dessa família à dessecação ou radiação. 


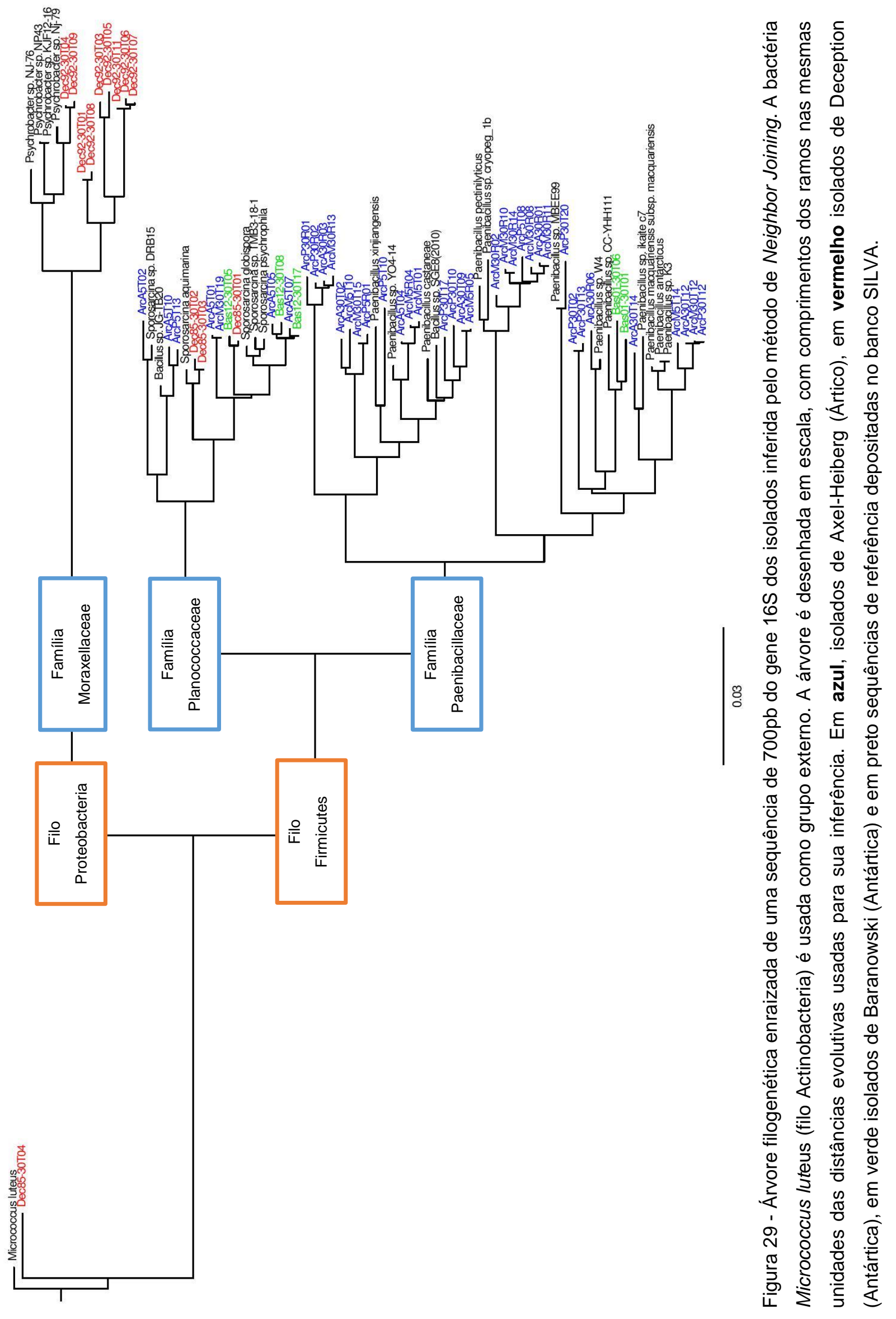


Segundo a análise taxonômica, a maior parte dos isolados do Ártico (32 isolados) e 2 isolados de Baranowski próximos à geleira (ponto 01), fazem parte da família Paenibacillacea, Filo Firmicutes. Bactérias do gênero Paenibacillus são anaeróbias facultativas, com células em forma de bastonetes e formadoras de endósporos. Esse gênero já foi descrito na Antártica, mas é também presente em muitos outros ambientes. Algumas espécies descritas são capazes de fixar nitrogênio enquanto outras são capazes de secretar enzimas que degradam celulose e outros polissacarídeos (MONTES et al., 2004; VAN DER MAAREL; VEEN; WIJBENGA, 2000). Além de metabolicamente bastante diverso, esse grupo por ser formador de endósporos teria uma resistência intrínseca às condições como calor, radiação e dessecação. No entanto não há dados de resistência à dessecação ou radiação descritos na literatura.

Do ponto 92 originado em Deception, coletado a $9 \stackrel{\circ}{\mathrm{C}}$, foram isoladas exclusivamente cepas de bactérias gram-negativas, do filo Proteobacteria, família Moraxellacea, próximas ao gênero Psychrobacter. O gênero Psychrobacter é composto de bactérias heterotróficas aeróbias, psicrotolerantes, com algumas espécies podendo crescer em temperaturas de até $-10{ }^{\circ} \mathrm{C}$ (BOWMAN, 2006). Bactérias desse gênero têm sido frequentemente isoladas de vários ambientes frios, incluindo gelo, solo e permafrost da Antártica e Sibéria, assim como em amostras de sedimento de mar profundo (AYALA-DEL-RIO et al., 2010). Em um estudo recente, Psychrobacter cryohalolentis K5, isolada de solos hipersalinos da Sibéria, Rússia, foi submetida a experimentos simulando condições da superfície de Marte e sua resistência à dessecação. O experimento demonstrou que $P$. cryohalolentis foi especialmente sensível ao processo de dessecação, exibindo redução de até seis ordens de grandeza em comparação ao controle (SMITH, D. J. et al., 2009).

O isolado mais distante filogeneticamente, Dec85-30T04, foi isolado da ilha Deception e é parte do Filo Actinobacteria, família Micrococcaceae. Foi mostrado que Micrococcos luteus, apesar de ser tolerante à dessecação, é sensível à radiação ultra violeta (MERRICK; BRUCE, 1965). Outro componente deste Filo, Arthrobacter siccitolerans, mostrou-se altamente resistente à dessecação. Essa bactéria foi isolada pelo grupo que primeiro desenvolveu a metodologia que utiliza solventes orgânicos como método de seleção de resistentes à anidrobiose, adaptada neste trabalho de doutorado (SANTACRUZ-CALVO; GONZÁLEZ-LÓPEZ; MANZANERA, 2013). 
4.3.3 Análises de resistência à dessecação

Um total de 23 cepas foram caracterizadas quanto a sua tolerância à dessecação: 1 cepa do Filo Actinobacteria, 4 cepas de Proteobacteria e 18 cepas de Firmicutes. A árvore filogenética destes isoladas encontra-se na figura 30.

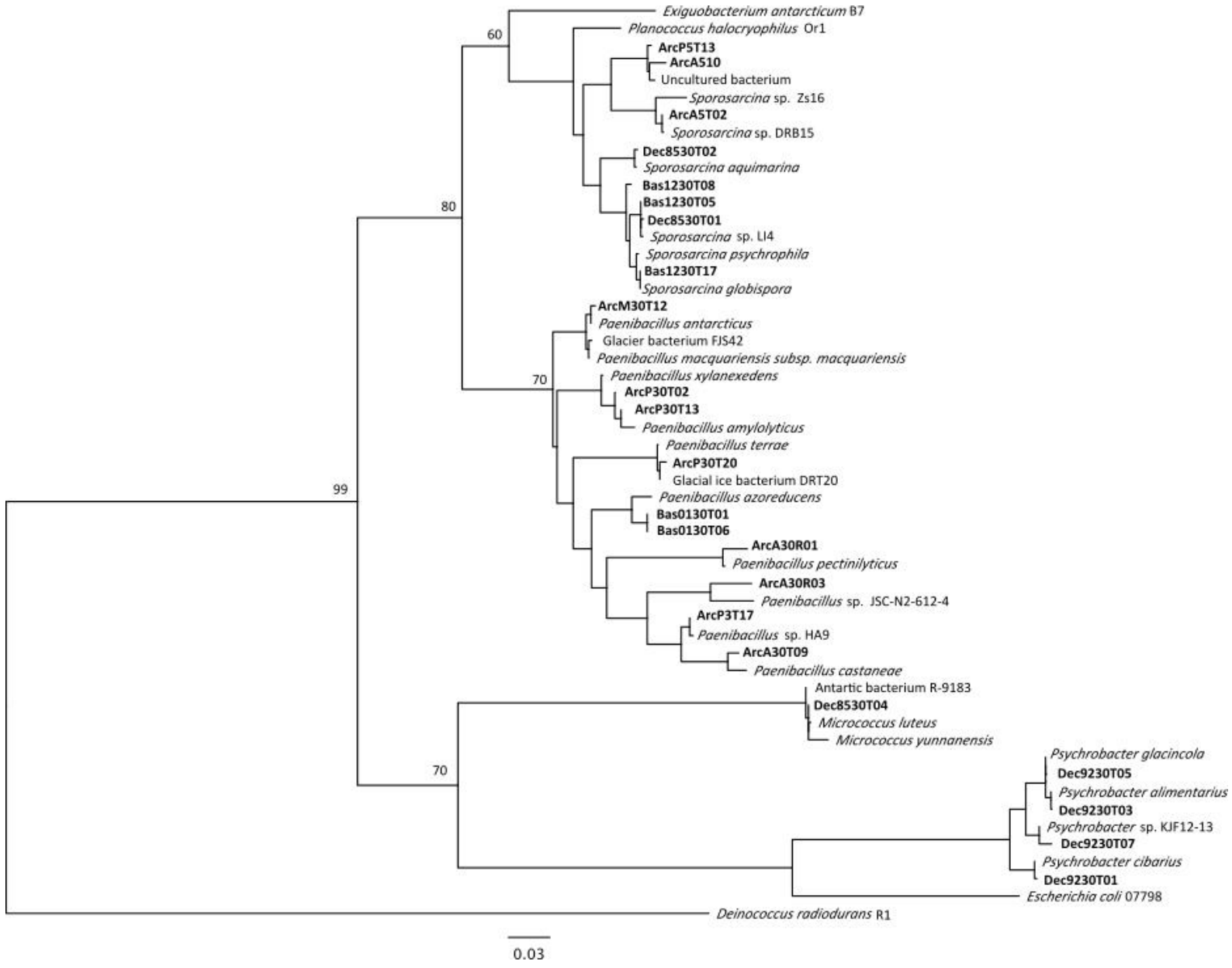

Figura 30 - Árvore filogenética baseada em sequências do gene 16S rRNA dos isolados resistentes à dessecação. A barra de escala indica 0,03 substituições por posição de nucleotídeo. Valores de bootstrap (\%), superior a 60 são mostrados nos nós.

Seis cepas não mostraram resistência à dessecação sob qualquer circunstância: ArcP0513, ArcA05T10, ArcA05T02 estirpes próximas, relacionadas ao gênero Sporosarcina; ArcA30R03, ArcA30T09, ArcM30T12 do gênero Paenibacillus. Seis dos micro-organismos isolados que sobreviveram ao tratamento com clorofórmio não mostraram qualquer tolerância à dessecação. Pode ser que algumas células, quando unidas a partículas do solo, se protejam contra a exposição ao clorofórmio e a perda de água. Além disso, o tempo de tratamento com clorofórmio desempenha também um papel na sobrevivência de microorganismos não tolerantes à dessecação (Narvaez-Reinaldo et al., 2010). O clorofórmio pode demorar mais de 30 minutos para 
danificar algumas células, mesmo quando eles não são totalmente resistentes a solventes orgânicos ou dessecação.

Todas as cepas apresentaram uma taxa de sobrevivência significativamente maior quando secas na presença de meio R2B 10\% (Figuras 31 e 32). As cepas de bactérias gram-negativas do filo Proteobacteria, isoladas de Deception Island, se mostraram altamente sensíveis quando dessecadas em suspensão de água. Da mesma forma, cepas controle só mostraram tolerância à dessecação quando secas em meio R2B 10\%, com exceção de $D$. radiodurans.

Tolerância à dessecação não se correlacionou com domínios específicos dentro dos grupos observados. As cepas mais resistentes foram encontradas dentro das famílias Micrococcaceae, Planococcaceae e Paenibacillaceae. Bactérias gramnegativas foram as mais suscetíveis à dessecação depois de serem ressuspensas em água.

As bactérias isoladas de Baranowski, mostraram uma taxa de sobrevivência similar, uma redução de 3 a 4 ordens de grandeza após 50 dias dessecação. Curiosamente, as estirpes de mesmo gênero, dentro de Paenibacillus e Sporosarcina, mas isoladas de diferentes amostras, mostraram resultados diferentes.

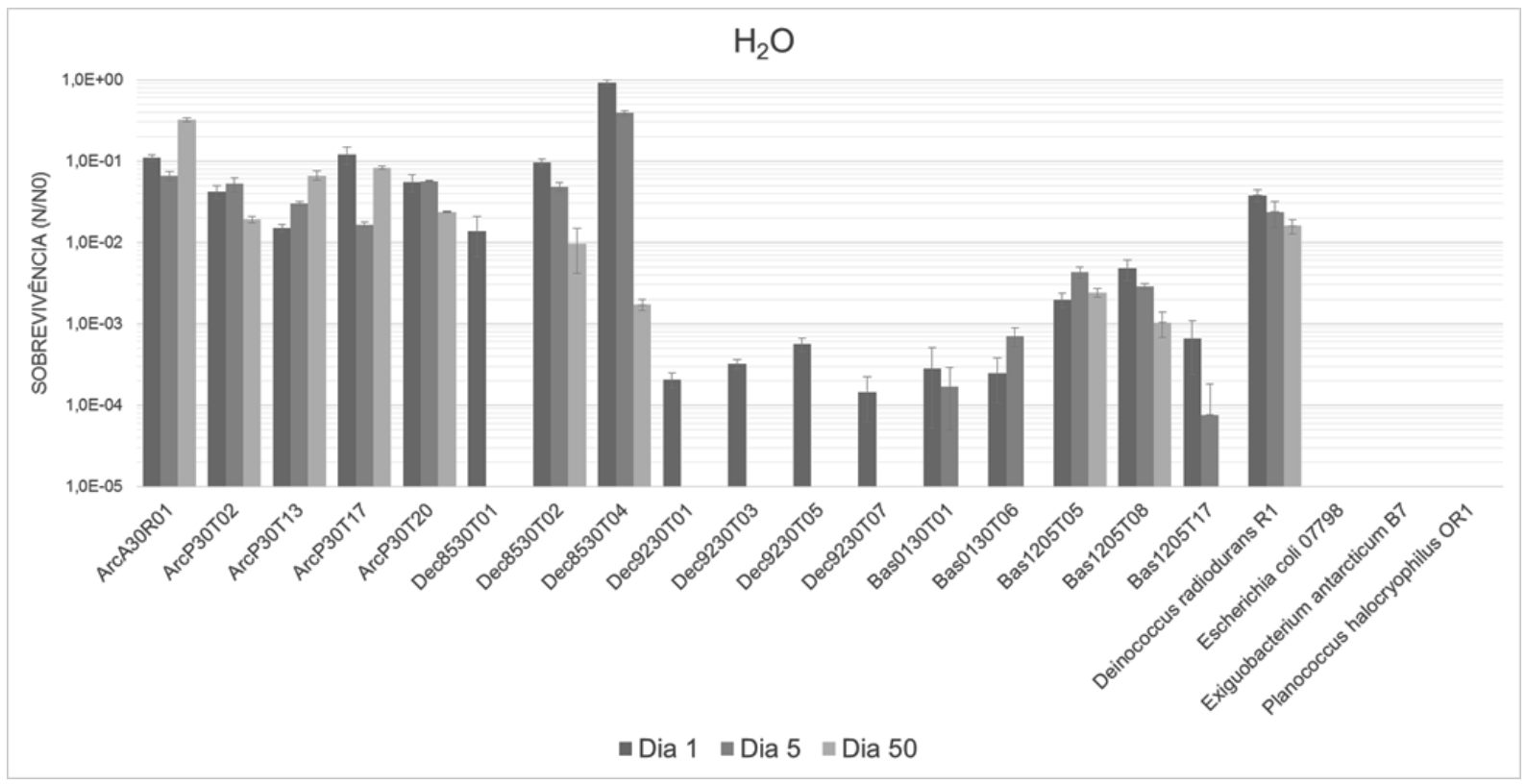

Figura 31 - Sobrevivência dos isolados após 1, 5 e 50 dias de secagem. Após o tratamento as células foram ressuspensas em água. 


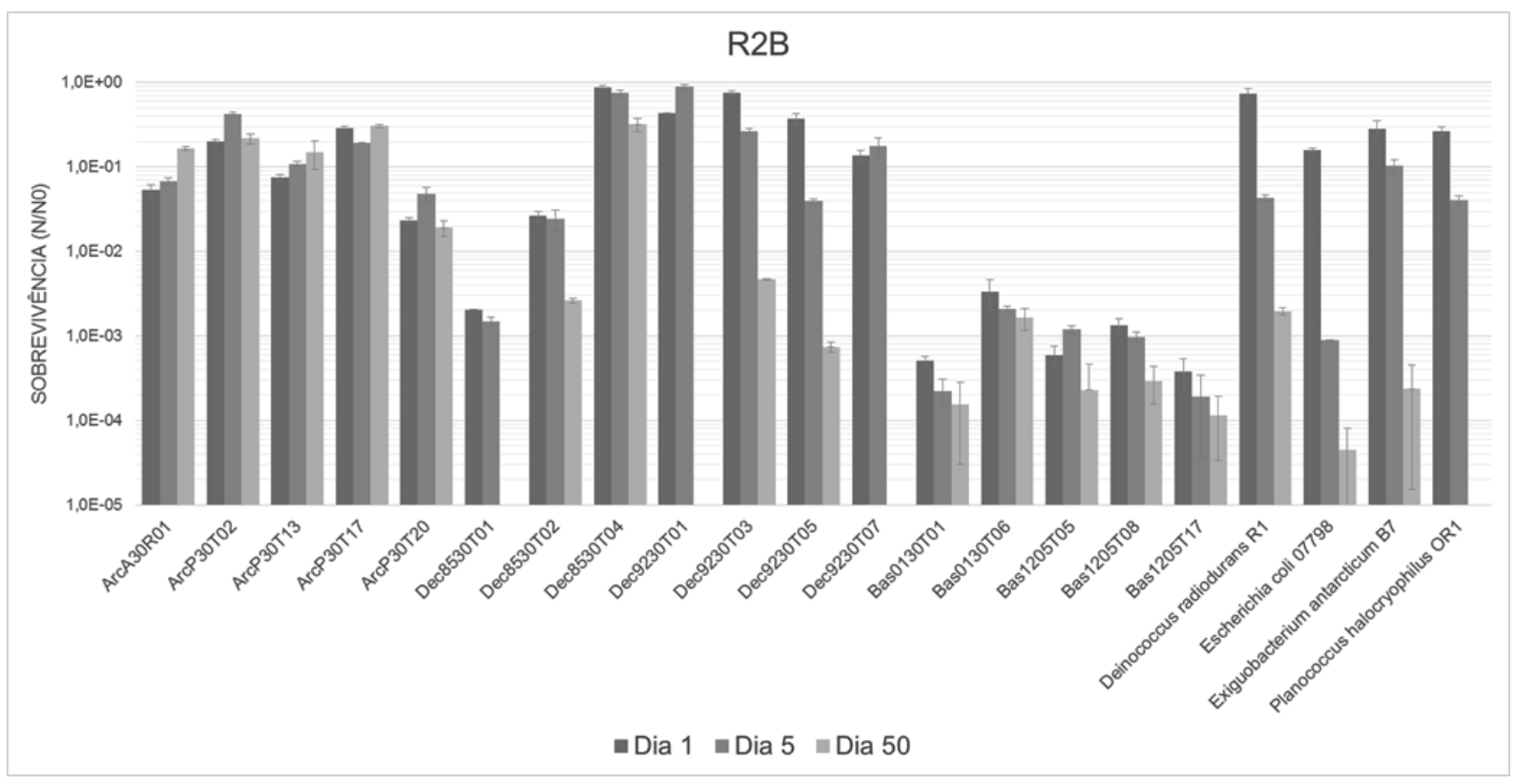

Figura 32 - Sobrevivência dos isolados após 1, 5 e 50 dias de secagem. Após o tratamento as células foram ressuspensas em meio R2B 10\%.

As taxas de sobrevivência foram superiores quando as células foram secas na presença da solução nutriente R2B diluído dez vezes. Os sais inorgânicos presentes na fórmula podem ter conferido proteção contra estresse osmótico sendo relevante para a sobrevivência de cepas sensíveis ao choque osmótico. Essa hipótese explica a baixa tolerância de $P$. halocryophilus, E. antarcticum (ambos adaptados à ambientes salinos), e bactérias gram negativas quando suspendidas em água antes do experimento (DALL'AGNOL et al., 2014; MYKYTCZUK et al., 2013; MYKYTCZUK; WILHELM; WHYTE, 2012). Além disso, foi mostrado que piruvato de sódio, uma fonte de energia para os metabolismos aeróbicos e anaeróbicos, pode ter um efeito protetor contra ROS nas células (GIANDOMENICO et al., 1997).

Algumas bactérias são capazes de formar esporos, que permitem que 0 organismo sobreviva em condições ambientais hostis, e resistir a agressões químicas e térmicas. Esse pode vir a ser o mecanismo de resistência encontrado em isolados próximos ao gênero Sporosarcina e Paenibacillus. Bactéria não formadoras de esporos, como as gram negativas, possuem outros mecanismos de resistência que protegem as células à danos ao deu DNA e danos oxidativos à maquinaria proteica da célula. $O$ isolamento de bactérias polares formadoras e não formadoras de esporo abre caminho para estudos futuros que podem buscar correlacionar diferente mecanismos de resistência à dessecação em função do tempo. Apesar dos experimentos terem sido realizados na presença de oxigênio, o metabolismo 
energético, se aeróbio facultativo ou estrito, pode também ter alguma influência na resistência à períodos prolongados de dessecação.

No âmbito da astrobiologia, além de estudos que procuram simular parâmetros químicos e físicos encontrados além da Terra, outros experimentos procuram também expor diretamente amostras biológicas ao espaço interplanetário (MEESSEN et al., 2015). A estrutura EXPOSE, parte da Estação Espacial Internacional, foi desenvolvida pela Agência Espacial Europeia (ESA) com esse objetivo, e permite expor amostras por um longo prazo (mais de um ano) com acompanhamento de das variações de pressão, temperatura, dose de UV, outras radiações encontradas na baixa órbita terrestre (RABBOW et al., 2009). Foram realizados estudos com algas, líquens e bactérias esporulantes ou não, com níveis de exposição variável (OLSSON-FRANCIS; COCKELL, 2010). A resistência à dessecação é uma premissa para resistência ao ambiente espacial da baixa órbita terrestre. A coleção de micro-organismos aqui descrita abre também a possibilidade de experimentos futuros que visam correlacionar diferentes níveis de tolerância à dessecação à resistência ao meio interplanetário em micro-organismos adaptados à ambientes polares terrestres.

\subsection{Diversidade microbiana em amostras de permafrost do Ártico Canadense}

\subsubsection{Biblioteca do gene 16S rRNA}

O DNA total extraído das amostras de permafrost de Axel Heiberg, Canadá, foi utilizado para o preparo de uma biblioteca de DNA para sequenciamento de alto rendimento. Todas as reações de amplificação foram realizadas com a polimerase Kapa $\mathrm{HiFi \circledast}$ (KapaBiosystem). Em um estudo realizado com o objetivo de averiguar a fidelidade de diferentes polimerases, propensão a introdução de erros e amplificação preferencial de sequências específicas, Quail (2012) demonstrou que a Kapa HiFi ${ }^{\circledR}$ seria a enzima menos propensa à introdução de desvios devido à PCR (QUAIL et al., 2012). A amplificação inicial teve como alvo as regiões V3 e V4 do gene rRNA $16 S$ bacteriano (Figura 5). Os primers utilizados foram descritos por Klindworth (2013) como sendo os mais promissores para as tecnologias de NGS. A cobertura de cada primer contendo um mismatch ou degeneração dentro do reino Bacteria é: $98,1 \%$ para o primer $341 \mathrm{~F}$ e $96,2 \%$ para $785 \mathrm{R}$. Quando se considera a cobertura alcançada pelo 
par de primers 341F e 785R, análises in silico indicam uma cobertura total de $70,9 \%$ para bactérias (KLINDWORTH et al., 2013).

Após a segunda reação de amplificação, cuja objetivo é atribuir índices duplos e adaptadores de sequenciamento específicos da plataforma Illumina, a biblioteca final purificada foi analisada no chip DNA 1000 do equipamento Bioanalyzer. O tamanho médio esperado para a biblioteca final é de cerca $630 \mathrm{pb}$. Todas as 9 bibliotecas apresentaram fragmentos de DNA dentro do intervalo esperado (figuras 33 e 34).

[bp]
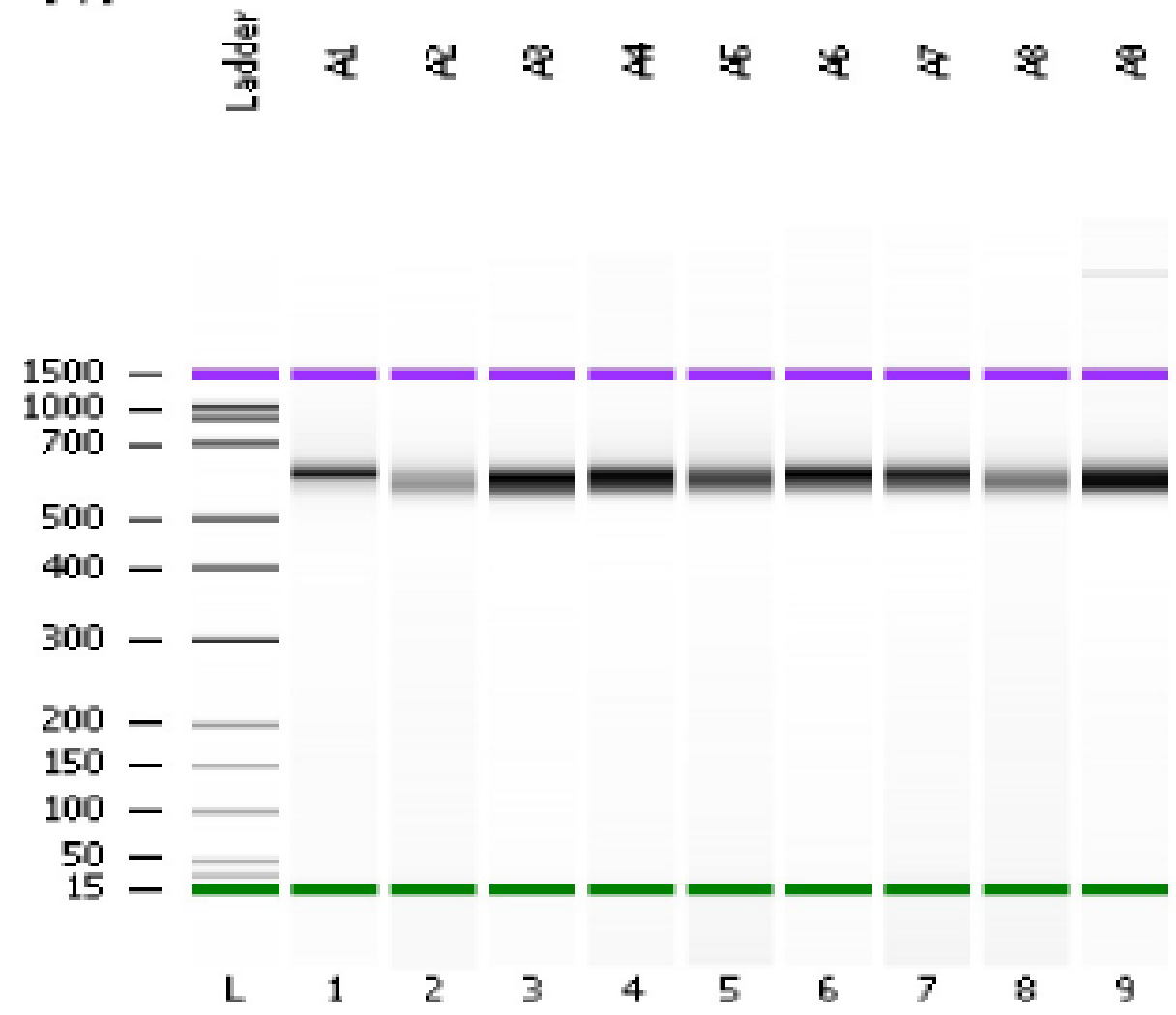

Figura 33 - Simulação de gel de eletroforese de DNA das bibliotecas, criado a partir de dados de densitometria gerados pelo 2100 Bioanalyzer. 
A1

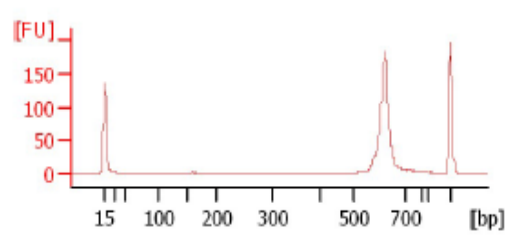

A4

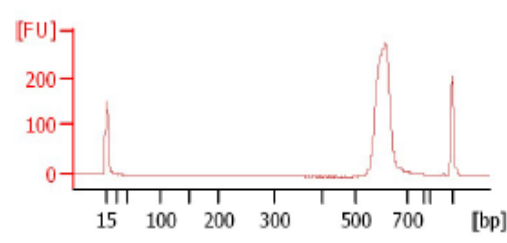

A7

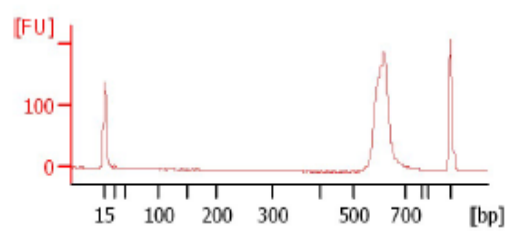

A2

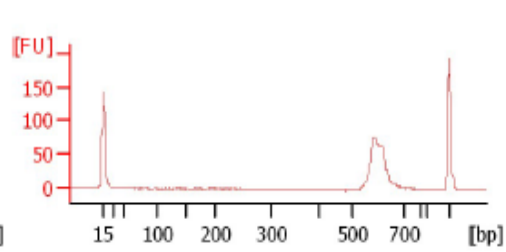

A5

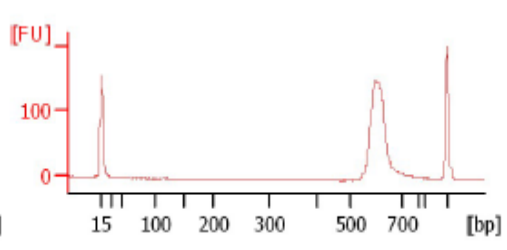

A8

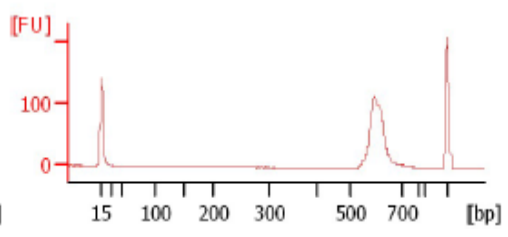

A3

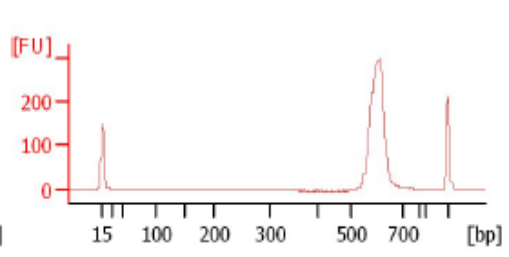

A6

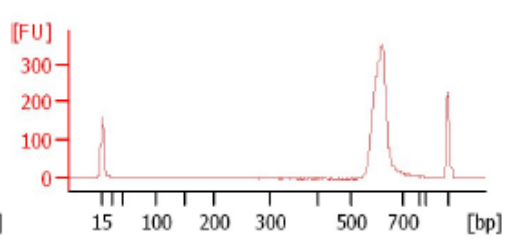

A9

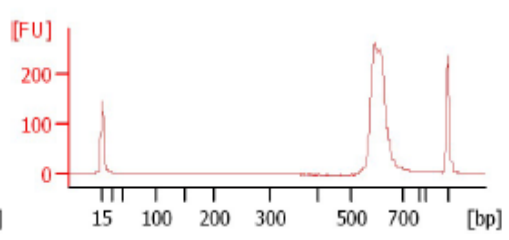

Figura 34 - Eletroferogramas das bibliotecas de DNA das amostras de Axel-Heiberg gerados no equipamento 2100 Bioanalyzer.

\subsubsection{Sequenciamento Illumina Miseq}

A qualidade do sequenciamento foi analisada por três parâmetros principais: Q-score, densidade de clusters e clusters passing filter (PF).

A Q-score é uma previsão da probabilidade de que uma base seja erroneamente identificada. Um Q-Score igual a Q20 dá a uma base sequenciada 1 chance em 100 de ter sido identificada de forma errada; Q30 1 chance em 1000 e assim sucessivamente. Os valores de Q-score são aferidos a partir do ciclo 25 . A distribuição de bases sequenciadas em relação ao seu Q-score e a porcentagem média de bases maior do que Q30 são mostradas na figura 35 .

A medida de densidade de clusters mostra o número de clusters de amplificação por milímetro quadrado formados na fase sólida da flow cell. Idealmente, a fabricante indica que a densidade do cluster deve ser $800 \mathrm{~K} / \mathrm{mm}^{2}$. No entanto, também considera o intervalo de $50 \mathrm{~K}-1300 \mathrm{~K} / \mathrm{mm}^{2}$ como valores aceitáveis. A densidade de clusters alcançado no sequenciamento foi de $381 \mathrm{~K} / \mathrm{mm}^{2}$ (Tabela 4). O sequenciamento gerou ao total cerca de 3 bilhões de bases identificadas, em 10373835 reads de exatamente 301 pb, em condições ótimas a fabricante estima a geração de até 15 bilhões de bases para o sistema MiSeq V3 aqui utilizado. 
A medida de clusters PF (passing filter) mostra a porcentagem de clusters de amplificação que correspondem à qualidade global medida pelo filtro de pureza Illumina. Clusters que não passam pelo filtro, muitas vezes são resultado da sobreposição de clusters na fase sólida do sequenciamento. O resultado do total de reads que passaram pelo filtro foi de $92,3 \%$ (Tabela 4)

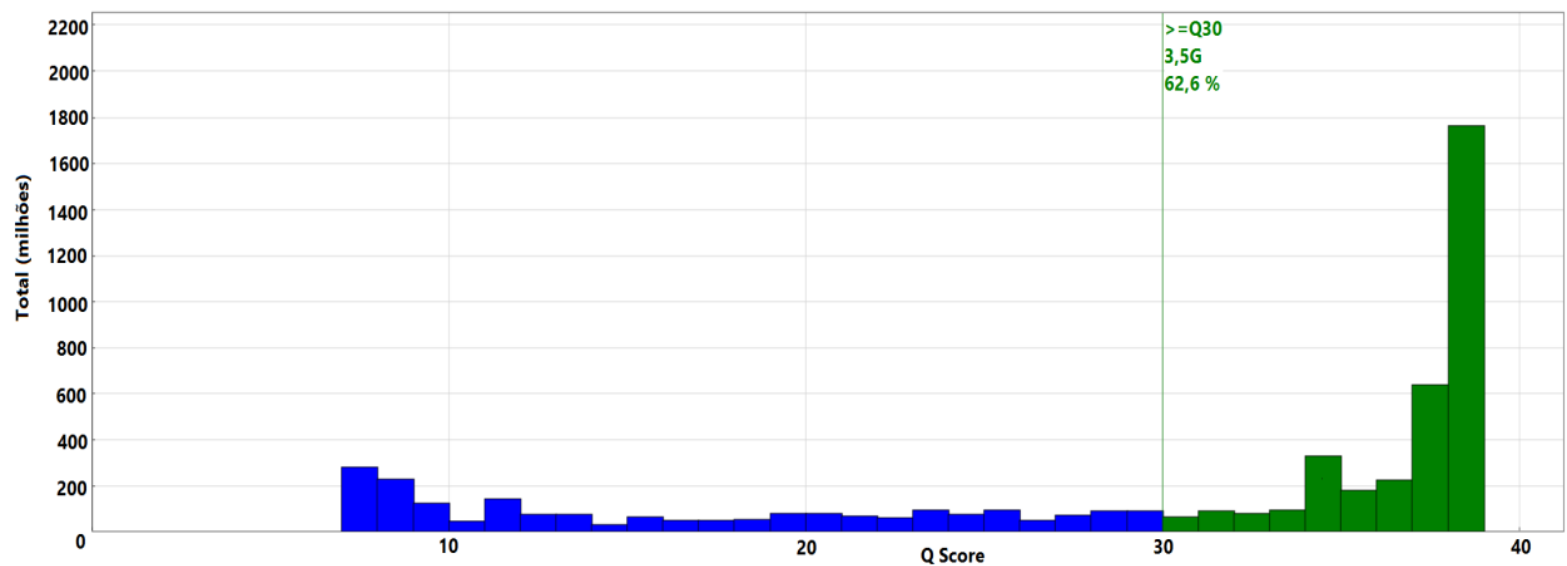

Figura 35 - Distribuição dos pares de bases sequenciados quanto ao seu valor de Q-Score ao final dos 600 ciclos de sequenciamento.

Tabela 4 - Dados referentes à a eficiência da reação de sequenciamento. Valores referentes à 96 bibliotecas que foram sequenciadas conjuntamente.

\begin{tabular}{ccccc}
\hline $\begin{array}{c}\text { Densidade de } \\
\text { Cluster }\left(\mathrm{K} / \mathbf{m m}^{2}\right)\end{array}$ & Clusters PF (\%) & Total de reads & Reads PF & Reads PF (\%) \\
\hline $381+/-20$ & $86,58+/-3,08$ & 10373835 & 8970909 & 92,32 \\
\hline
\end{tabular}

O número total de reads obtidas para todas as 9 bibliotecas geradas a partir das amostras de Axel Heiberg foi de 568.433, em média 63.159 sequências por amostra. A variação no número de sequências geradas entre as amostras deve ser consequência de imprecisões na quantificação das bibliotecas, etapa anterior à formação do pool de DNA que foi por fim sequenciado. Durante o sequenciamento, em uma única flow cell, 96 bibliotecas competem pela formação de clusters no estágio de amplificação em fase sólida, sendo, portanto, fundamental a quantificação precisa de cada biblioteca. Com a união das sequências obtidas do mesmo estrato do testemunho do solo, as amostras pertencentes à camada ativa (a1, a2 e a3) passaram a contar com 250.027 sequências; camada de interface (m1, m2 e m3) 147.016 sequências; e permafrost (p1, p2 e p3) 171.390 sequências. 
Há uma diminuição significativa na Qscore após cerca de 200 ciclos no caso da primeira read e, em seguida, em torno do ciclo 450, referente a posição 150 pb da segunda read do mesmo amplicon. Isto não tem um impacto muito grande no resultado final, mas explica a diferença entre o número de reads antes e depois do corte de sequências por qualidade.

As reads paired-end obtidas de cada amostra foram utilizadas para a formação de contigs. A remoção das sequências pertencentes à primers e adaptadores, erros de sequenciamento e sequências quimera foram realizadas seguindo o protocolo de curadoria recomendada por Schloss (2013). O número de sequências por amostra antes e após o tratamento para remoção de erros está detalhado na tabela 5 . Ao final, 255424 sequências contíguas foram utilizadas para as análises subsequentes. $O$ tamanho médio das contigs foi de 433 pares de bases.

Tabela 5 - Lista de amostras sequenciadas, número total de contigs antes e após curadoria das sequências, total de contigs e média de contigs por amostra.

\begin{tabular}{ccc}
\hline Amostra & Número de contigs & Número de contigs curadas \\
\hline a1 & 92606 & 34951 \\
a2 & 84155 & 36793 \\
a3 & 73261 & 35810 \\
m1 & 39590 & 15838 \\
m2 & 63892 & 29177 \\
m3 & 43536 & 17835 \\
p1 & 51184 & 22866 \\
p2 & 59631 & 30059 \\
p3 & 60573 & 32095 \\
\hline Total de contigs & 568428 & 255424 \\
Média de contigs & 63159 & 28380 \\
\hline
\end{tabular}

\subsubsection{Estimativa de riqueza e diversidade}

Nesta seção, é apresentado o resultado de diferentes abordagens para o estudo da diversidade microbiana presente nos diferentes estratos do testemunho de solo coletado em Axel Heiberg. Abordagens estatísticas inicialmente desenvolvidas para comunidades de plantas e animais provaram ter utilidade para o estudo da ecologia e evolução da diversidade microbiana em ambientes naturais (HUGHES et 
al., 2001). Análises de alfa e beta diversidade foram realizadas com a definição de OTUs, utilizando um cutoff de similaridade genética.

Primeiramente, foram estimadas as curvas de rarefação de cada amostra, que fornecem uma maneira de comparar a riqueza observada em diferentes amostras e são um indicativo de confiança de que o trabalho de amostragem foi suficiente para correlacionar o resultado do estudo com o observado no ambiente como um todo.

Foram calculadas as curvas de rarefação de OTUs de todas as amostras sequenciadas para o cutoff de espécie $(0,03)$. Triplicatas referentes ao mesmo estrato do testemunho foram analisadas individualmente (Figuras 36,37 e 38 ) e posteriormente unidas para análise entre os estratos (Figura 39). Foi utilizado uma subamostragem aleatória para os cálculos das curvas de rarefação. O número de sequências incluídas nesta análise foi igual ao menor número de sequências dentre as amostras analisadas; 15838 sequências para cada uma das triplicatas; 62850 sequências para a análise entre os estratos. Essa metodologia permite a comparação direta entre as curvas de rarefação obtidas nas diferentes amostras.

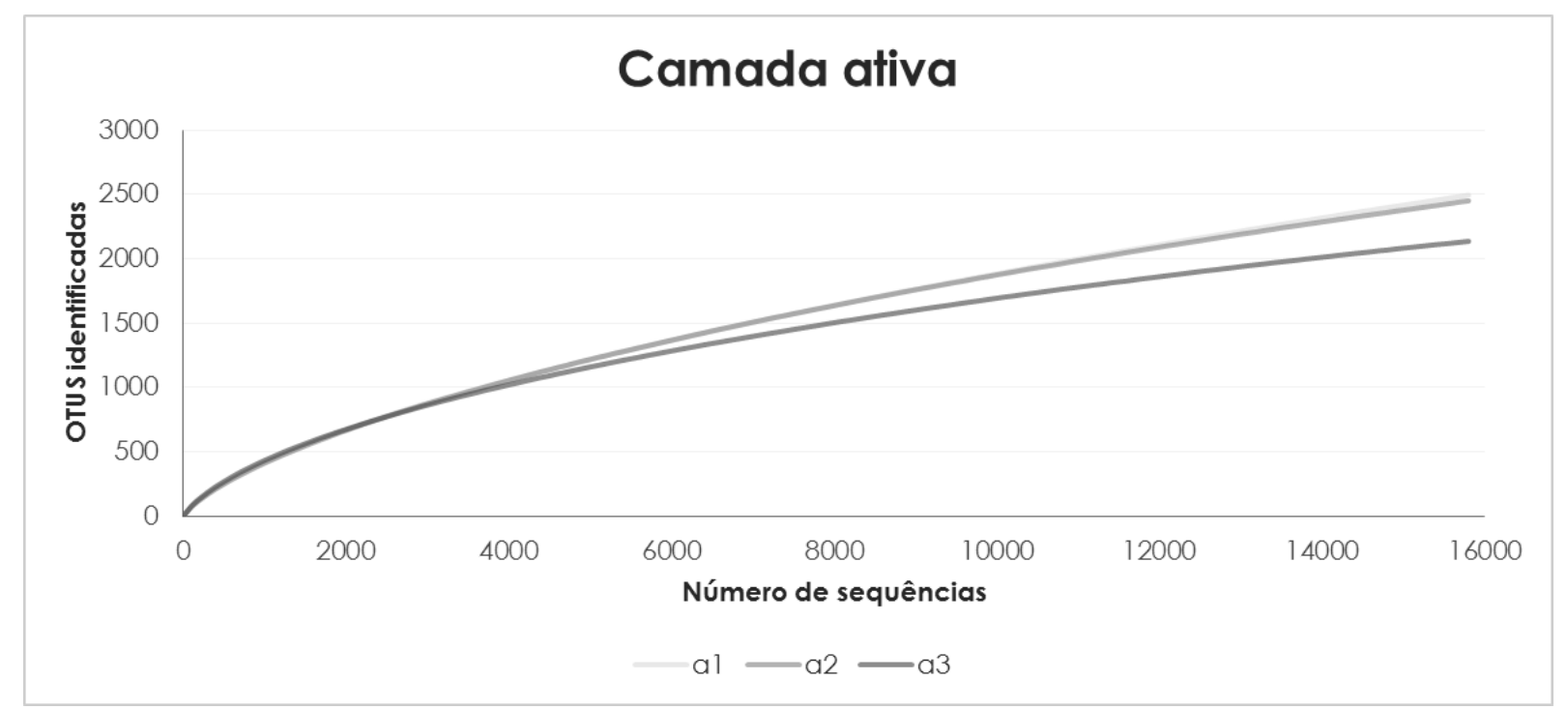

Figura 36 - Curvas de rarefação estimadas para as amostras de superfície (a1, a2 e a3) do testemunho de solo de Axel-Heiberg. Valor de cutoff: 0,03. 


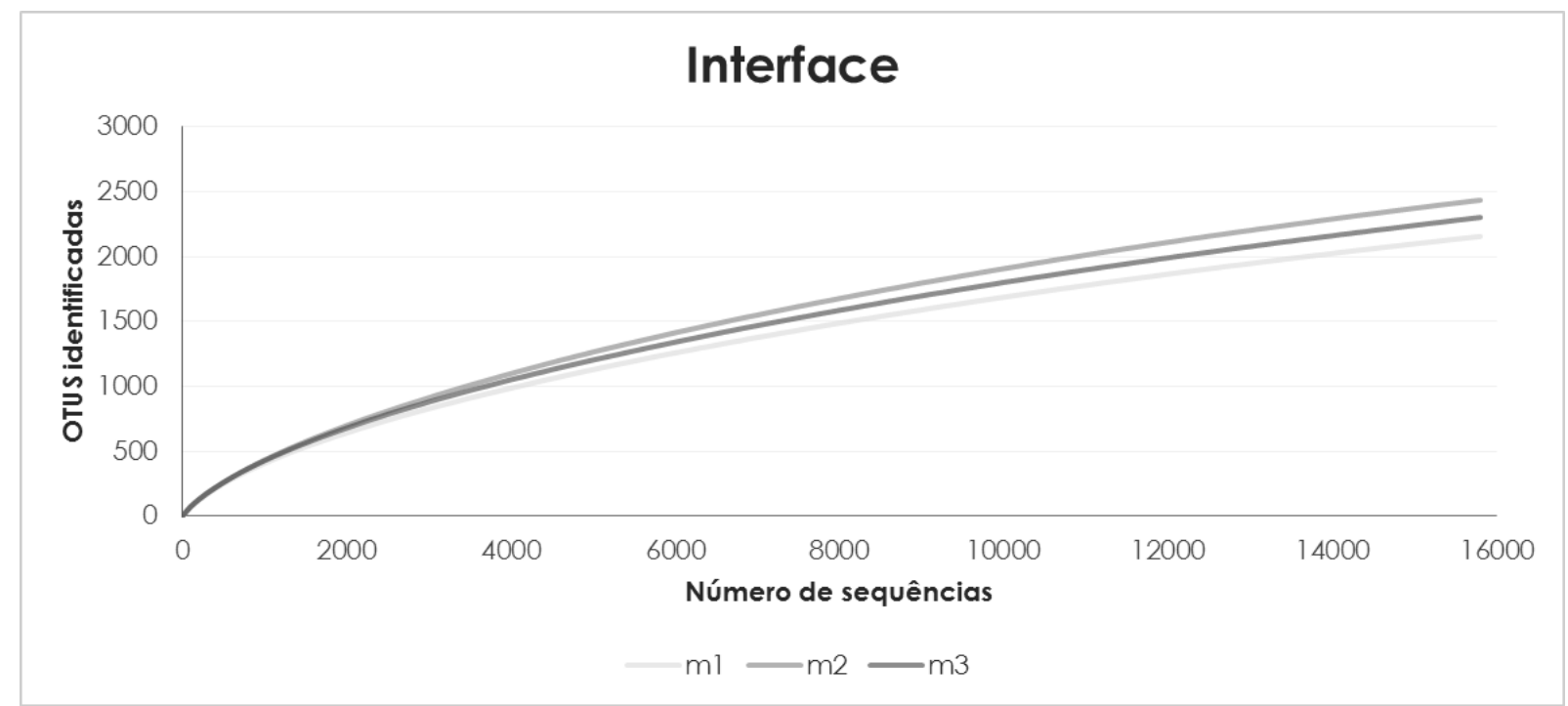

Figura 37 - Curvas de rarefação estimadas para as amostras de interface (m1, m2 e m3) do testemunho de solo de Axel-Heiberg. Valor de cutoff: 0,03.

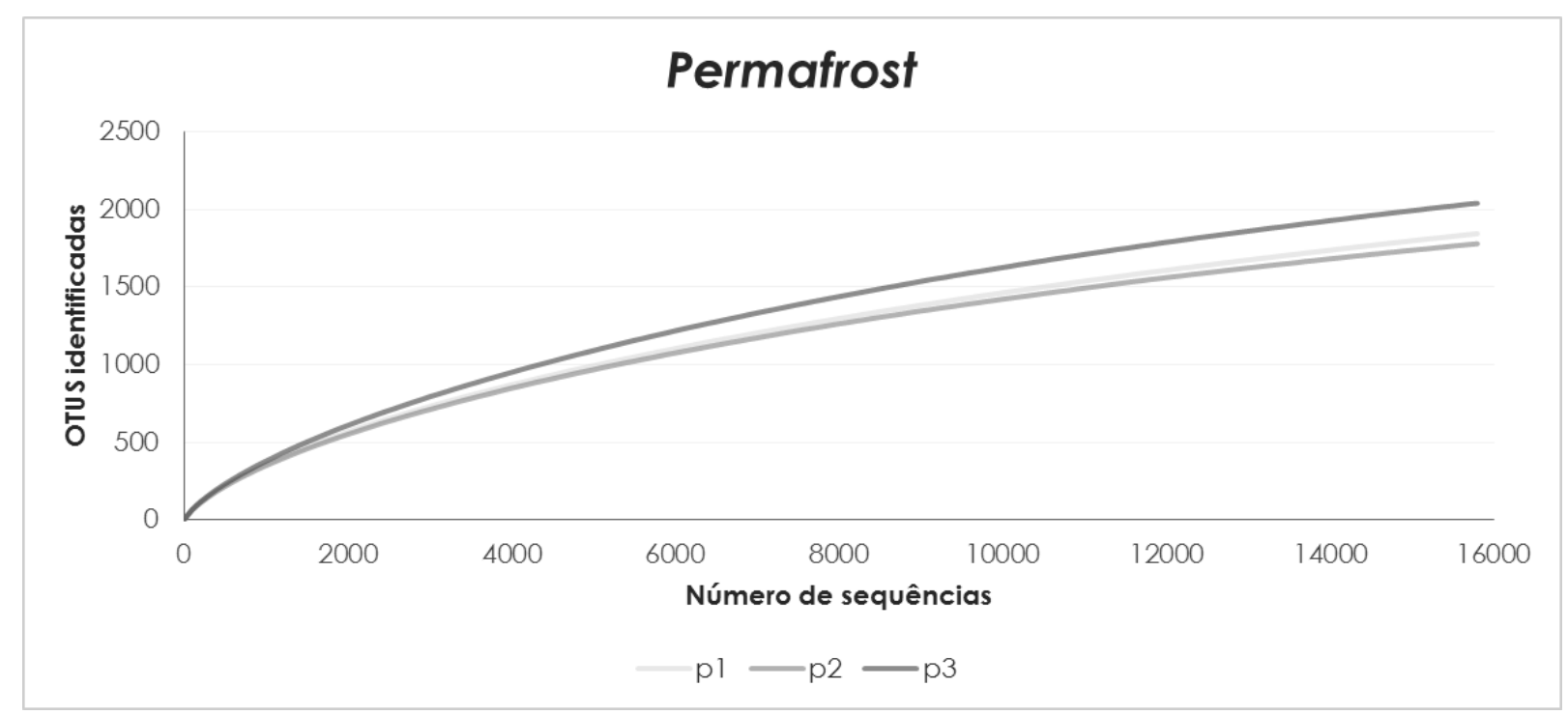

Figura 38 - Curvas de rarefação estimadas para as amostras de permafrost (p1, p2 e p3) do testemunho de solo de Axel-Heiberg. Valor de cutoff: 0,03. 


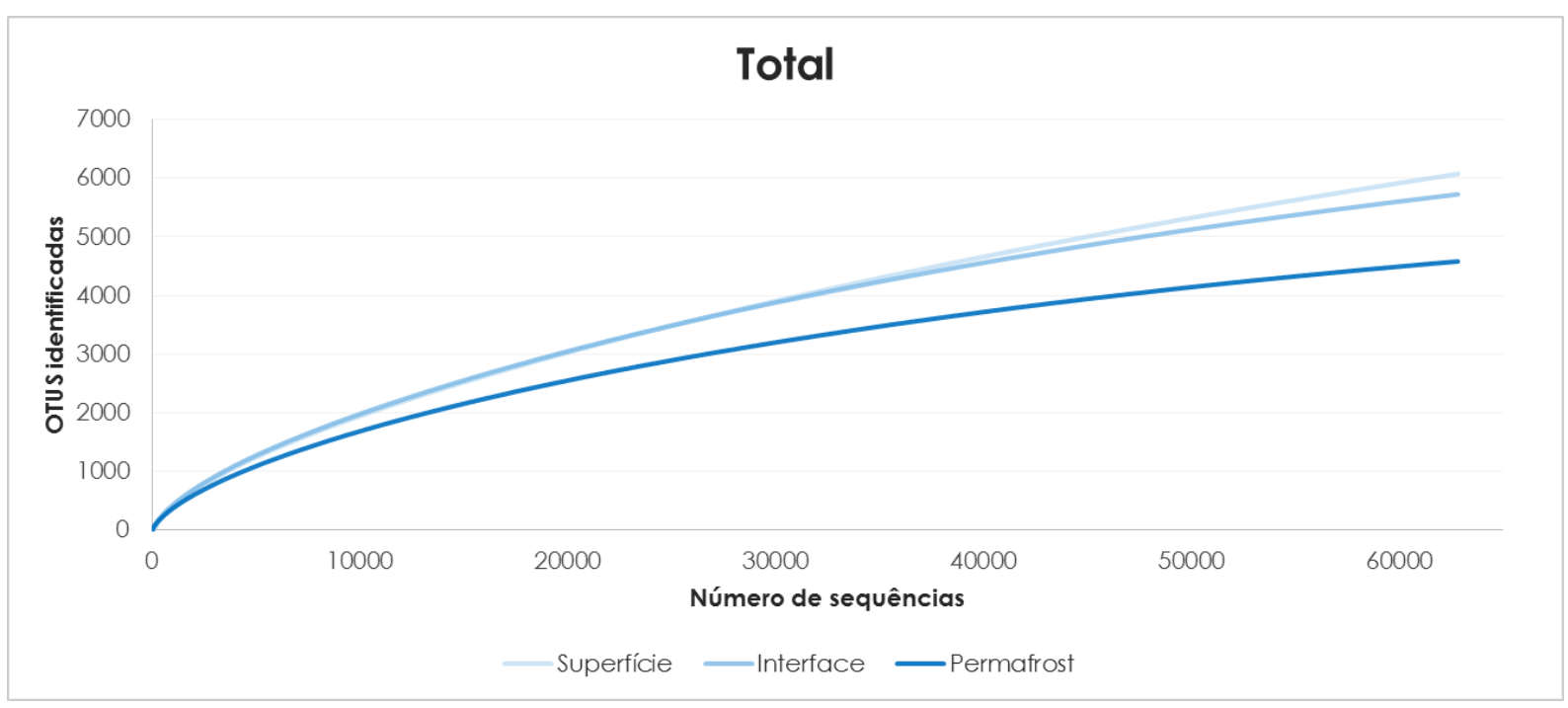

Figura 39 - Curvas de rarefação estimadas para as amostras de superfície (a), interface $(m)$ e permafrost ( $p$ ) do testemunho de solo de Axel-Heiberg. Valor de cutoff: 0,03.

As curvas de rarefação para as amostras de Axel Heiberg demonstraram que o esforço amostral não foi inteiramente suficiente para cobrir a riqueza de espécies, nem mesmo quando se juntam as triplicatas do mesmo estrato. Entretanto, as curvas já começam a mostrar sinais de saturação com o esforço amostral disponível, ou seja, o aumento do número de sequências não resultaria em um aumento linear no número de OTUs únicas identificadas. As triplicatas referentes ao mesmo estrato não apresentam diferenças significativas.

Enquanto as curvas referentes as amostras de superfície e interface apresentaram comportamento bastante similar entre si; a curva de rarefação das amostras de permafrost apresentou menor inclinação quando comparada aos outros estratos. A curva de rarefação da amostra de permafrost estima cerca de 4500 OTUs para 60 mil sequências analisadas. As curvas para as amostras de superfície e interface, estimam cerca de 5900 e 5600 OTUs, respectivamente, para o mesmo número de sequências analisadas. Estes resultados sugerem que as amostras pertences ao permafrost de Axel Heiberg possuem menor riqueza estimada que as amostras da camada ativa (superfície) e da camada intermediária do testemunho de solo analisado.

Em seguida, os índices de riqueza, diversidade e cobertura da amostragem para as amostras de Axel Heiberg foram calculados a partir de uma matriz de distância entre as sequências, utilizando-se novamente o cutoff de $3 \%$. Os resultados encontram-se na Tabela 6. 
Tabela 6 - Números de OTUs únicas e índices de alfa-diversidade e cobertura estimados para as sequencias do perfil de solo do Ártico Canadense obtidas através de sequenciamento de nova geração. Subsample utilizado: 15838 sequências; Valor de cutoff 0,03

\begin{tabular}{cccccccc}
\hline amostra & sobs & chao & ace & shannon & simpson & nseqs & coverage \\
\hline a1 & 2496 & 5734 & 9898 & 5,989 & 0,011 & 15838 & 0,904 \\
a2 & 2452 & 4646 & 7529 & 5,881 & 0,015 & 15838 & 0,913 \\
a3 & 2138 & 3557 & 5184 & 6,109 & 0,007 & 15838 & 0,934 \\
m1 & 2157 & 3646 & 5346 & 5,664 & 0,027 & 15838 & 0,931 \\
m2 & 2437 & 3816 & 5593 & 5,796 & 0,025 & 15838 & 0,924 \\
m3 & 2304 & 3865 & 5789 & 5,857 & 0,021 & 15838 & 0,926 \\
p1 & 1846 & 2982 & 3976 & 5,224 & 0,043 & 15838 & 0,944 \\
p2 & 1780 & 2664 & 3264 & 5,208 & 0,04 & 15838 & 0,949 \\
p3 & 2042 & 2935 & 3364 & 5,596 & 0,018 & 15838 & 0,942 \\
\hline
\end{tabular}

A cobertura se mostrou excelente, com valores acima de $90 \%$ para todas as amostras sequenciadas. A alta cobertura motivou a manutenção do cutoff de 0,03 , para as análises de diversidade realizadas a partir daqui.

Os índices de riqueza, no caso do cutoff utilizado de 0,03 , procuram estimar o número de espécies únicas em uma comunidade. As amostras de permafrost de Axel Heiberg tiveram índices de riqueza Ace e Chao menores do que as amostras de superfície e interface em todas as réplicas (Figura 40). Este resultado está em concordância com os resultados das curvas de rarefação obtidas para o mesmo cutoff e sugerem que a comunidade do permafrost tem um menor número de espécies, quando comparado aos outros estratos do testemunho. Comparando os valores de Chao e ACE, nota-se que o segundo estima um valor maior de riqueza de espécies para todas amostras. As replicatas em geral apresentaram valores de Chao e ACE similares às amostras provenientes do mesmo extrato. Exceção feita as amostras da camada ativa que apresentaram índices de riqueza de maior variância. Tomando como parâmetro uma média das amostras de superfície (a1, a2, a3) observa-se que a camada ativa das amostras de Axel Heiberg apresenta maior riqueza, em ambos os índices, quando comparado com a camada intermediária. Os índices Chao e ACE, portanto, indicam um decréscimo na riqueza de espécies correlacionado com o aumento da profundidade em que as amostras foram coletadas.

Os índices de diversidade, além de estimar o número de espécies presentes na amostra (riqueza), levam em consideração a uniformidade da distribuição de abundância das espécies consideradas (equitativide). Os índices de diversidade de 
Shannon e Simpson (lembrando que os números relativos gerados pelo índice de Simpson são inversamente proporcionais à diversidade da amostra considerada) indicam que a amostra de permafrost possui além de uma menor riqueza de espécies, menor diversidade (Figura 41). No entanto, vale notar, que a réplica p3 mostrou uma diversidade superior às réplicas p1 e p2. Analisando os resultados de todas os estratos do testemunho, o índice de diversidade se comporta de forma semelhante ao de riqueza; a diversidade diminui conforme aumenta a profundidade em que habitam as comunidades.

Amostras de permafrost de 1 metro de profundidade em Nome Creek, Alaska, também demonstraram que a diversidade microbiana de solo permanentemente congelado é menor do que nos solos da camada ativa (TAS et al., 2014). Este resultado talvez possa ser explicado pelas condições altamente seletivas encontradas em ambiente de permafrost. No Ártico Canadense, a comunidade bacteriana de permafrost tem sido estudada, mas não comparando a diversidade microbiana em relação a profundidade do solo, tampouco com a cobertura aqui descrita.

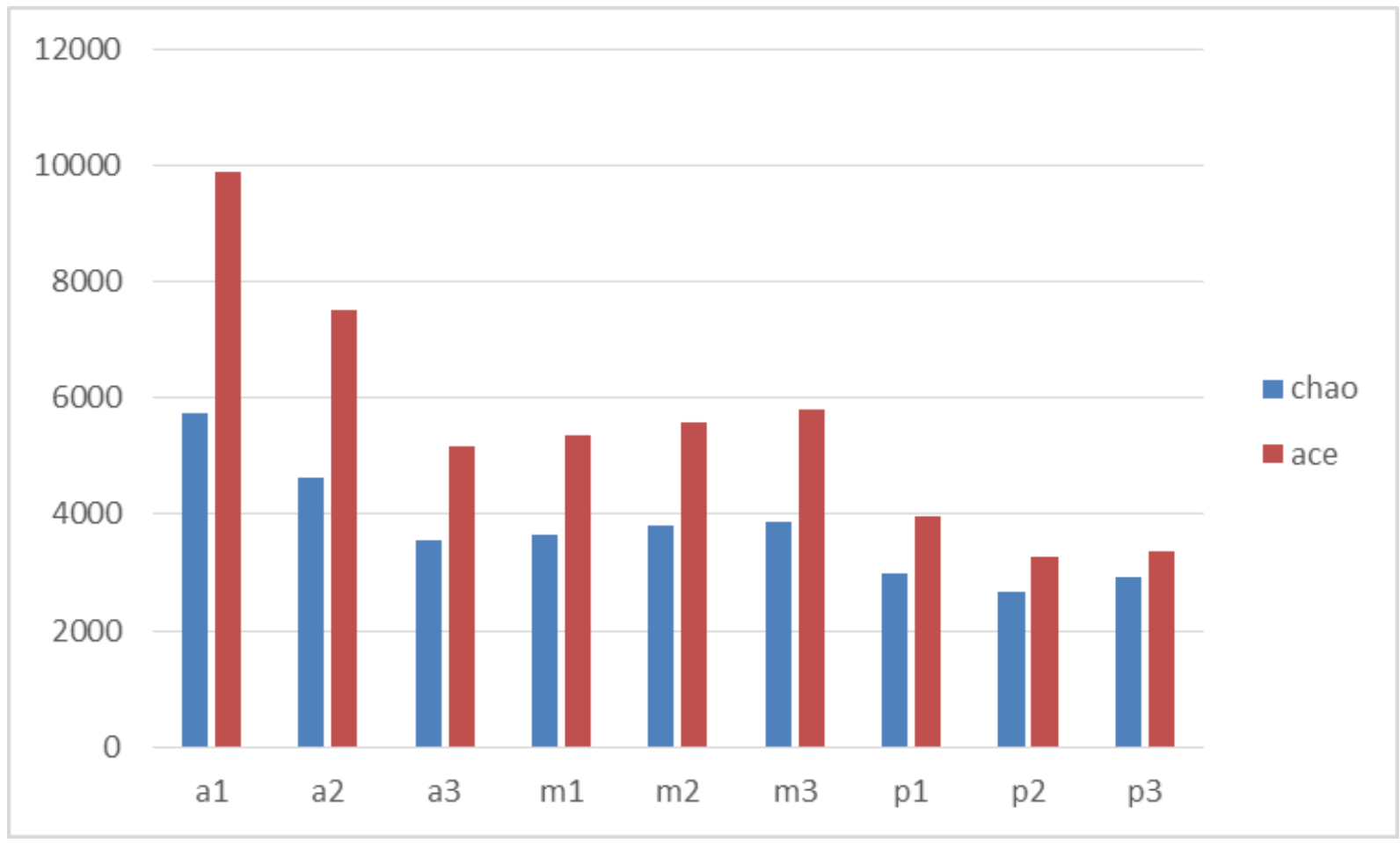

Figura 40 - Índices de riqueza Chao e Ace calculados para as amostras de Axel-Heiberg. Valor de cutoff 0,03 . 


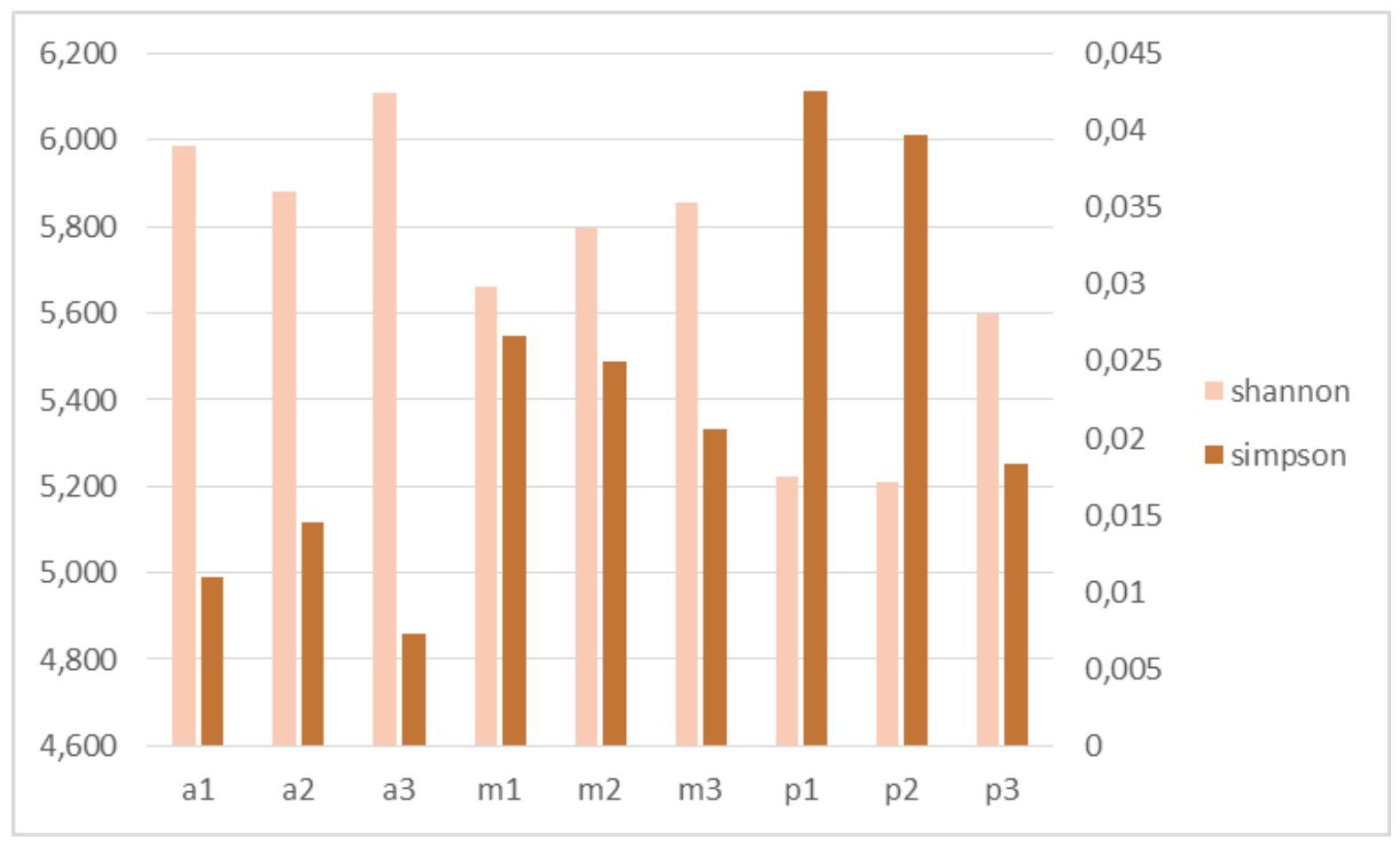

Figura 41 - Índices de riqueza Shannon e Simpson calculados para as amostras de Axel-Heiberg. Valor de cutoff $0,03$.

\subsubsection{Comparação da estrutura da comunidade entre amostras de Permafrost} através de métodos baseados em OTU

A comparação da composição e estrutura da comunidade por métodos baseados em OTU permite também quantificar a riqueza e a diversidade compartilhada entre diferentes amostras. Grosso modo, em um extremo podemos ter amostras que tem a mesma composição (compartilhando todas as espécies) e do lado oposto amostras que não compartilham nenhuma espécie. Este tipo de comparação relativística também é conhecido por beta-diversidade.

Como forma de representar os resultados das análises de riqueza compartilhada, foram gerados diagramas de Venn comparando o número de OTU compartilhadas (sharedsobs ou sobs) entre as amostras (Figura 42). O cutoff utilizado de 0,03 foi o mesmo usado ao longo deste trabalho.

Inicialmente, replicatas provenientes do mesmo estrato do testemunho de solo de Axel Heiberg foram comparadas quanto ao número de OTUs compartilhadas. As replicatas da camada superficial apresentaram 695 OTUs compatilhadas pelas três réplicas; 550 OTUs compartilhadas por pelo menos duas réplicas e 3872 OTUs $(75,7 \%$ do total) exclusivas de alguma das réplicas. 
As replicatas da camada de transição apresentaram 667 OTUs compartilhada pelas três réplicas; 545 OTUs compartilhadas por pelo menos duas réplicas e 3833 OTUs ( $76 \%$ do total) exclusivas de alguma das réplicas.

As replicatas pertencentes à camada de permafrost apresentaram 550 OTUs compartilhada pelas três réplicas; 503 OTUs compartilhadas por pelo menos duas réplicas e 2968 OTUs (60,3\% do total) exclusivas de alguma das réplicas.

O alto número de OTUs exclusivas para as replicatas de cada estrato está de acordo com o a análise do resultado das curvas de rarefação para o OTUs de cutoff 0,03 . Mesmo com a realização de três extrações de DNA e alto número de sequências obtidas com a técnica de sequenciamento de alto rendimento o esforço amostral não foi inteiramente suficiente para cobrir a riqueza de espécies em nenhuma das três camadas. Esse resultado sugere que variações intrínsecas do mesmo estrato de solo influenciam as comunidades microbianas quando observadas ao nível de espécies. Também fica evidente a importância da realização de triplicatas amostrais para a análise em ecologia microbiana ao nível de espécie. 


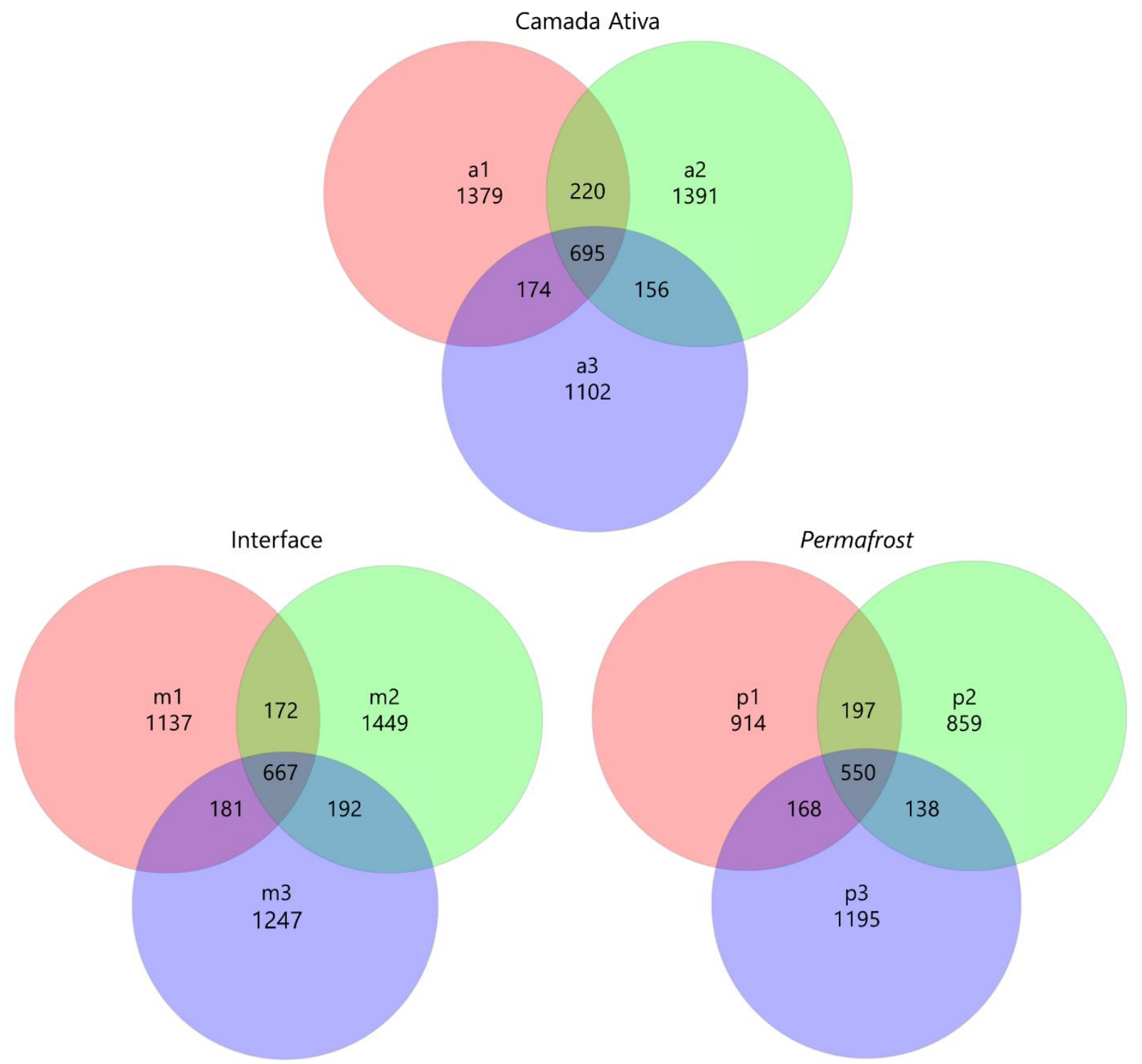

Figura 42 - Diagrama de Venn representando o número de OTU compartilhadas entre as amostras da camada ativa (a1, a2 e a3), entre as amostras de solo de transição ( $\mathrm{m} 1, \mathrm{~m} 23 \mathrm{~m} 3)$ e entre amostras do permafrost (p1, p2 e p3) do testemunho de solo de Axel-Heiberg. Valor de cutoff: 0,03.

A análise do número de OTUs compartilhadas entre os diferentes estratos do testemunho de solo de Axel Heiberg está apresentado na figura 43. Para esta análise as nove amostras foram unidas em três conjunto de dados: camada ativa (a), interface (m) e permafrost ( $p$ ). 795 OTUs foram compartilhadas entre os três estratos do testemunho de solo, sugerindo que estes grupos têm ampla distribuição e talvez um papel importante na comunidade do solo de Axel Heiberg. Apesar da maior distância, a camada ativa compartilha um número maior de OTUs com o permafrost do que com a camada de transição, 387 e 235 OTUs compartilhados, respectivamente. Porém o permafrost compartilha de maior proporção de OTUs provenientes da camada de interface, 543 OTUs compartilhadas, do que com a camada de superfície, 387 OTUs 
compartilhadas. Esses resultados sugerem que a camada de superfície seja a mais distinta quanto a composição microbiana do que as amostras de permafrost e da camada de transição.

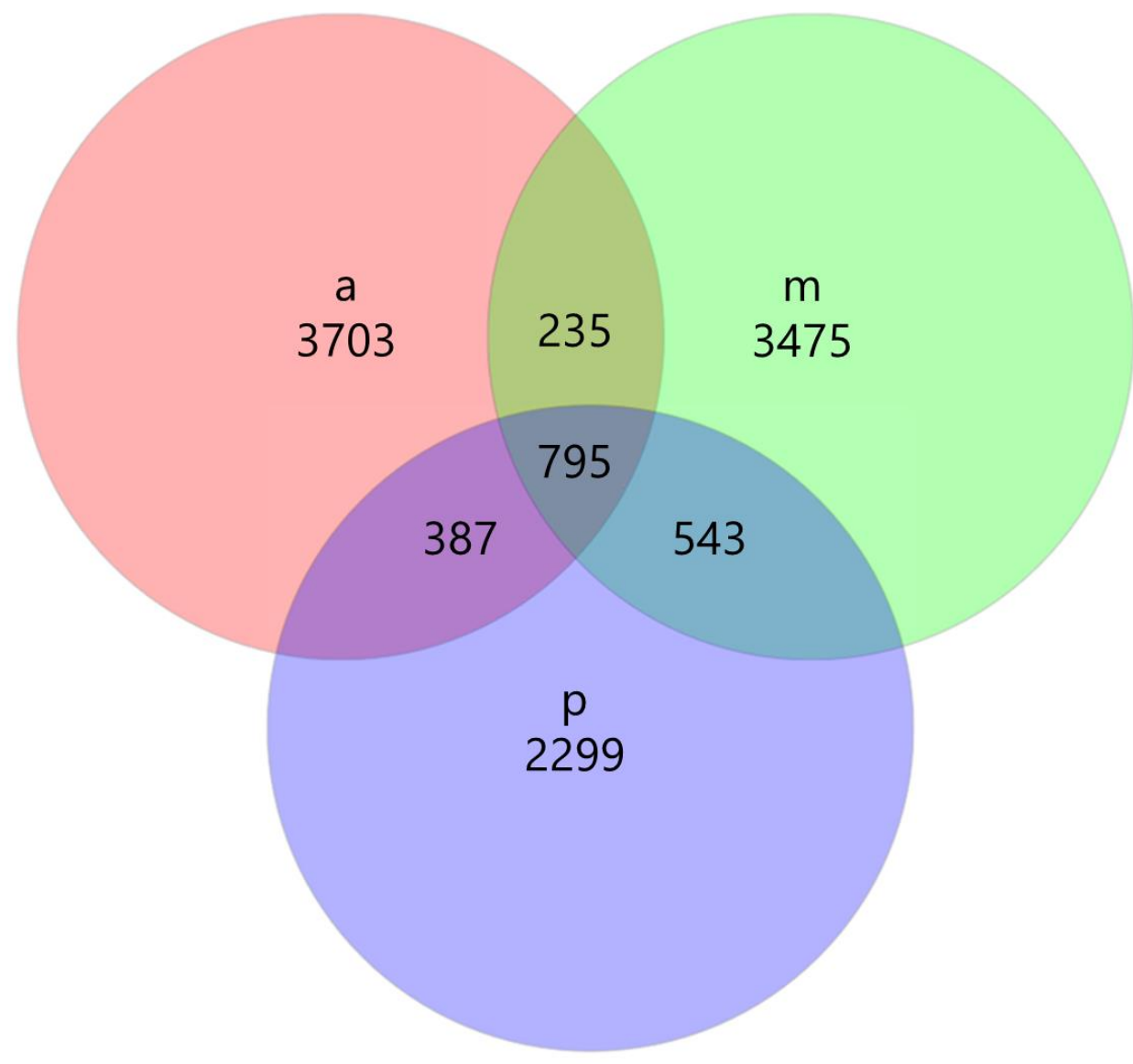

Figura 43 - Diagrama de Venn representando o número de OTU compartilhadas entre as amostras de camada ativa $(a)$, interface $(m)$ e permafrost $(p)$ do testemunho de solo de Axel-Heiberg. Valor de cutoff: 0,03 .

A similaridade entre as comunidades foi também estimada através dos coeficientes de Bray-Curtis e do índice theta de Yue \& Clayton. Estes índices de similaridade fornecem uma medida com base quantitativa para a comparação das amostras de par em par, e consideram as abundâncias relativas de OTUs compartilhadas.

O coeficiente de Bray-Curtis é amplamente difundido em análises de ecologia por fornecer um meio simples, porém estatisticamente significativo de comparação de similaridade entre comunidades. $\mathrm{O}$ índice normalizado associa um número entre $0 \mathrm{a}$ 1 quando comparadas amostras, aonde 0 significa que duas comunidades possuem a mesma composição, enquanto 1 significa que elas são completamente diferentes (BRAY; CURTIS, 1957; CLARKE; SOMERFIELD; CHAPMAN, 2006). 
Já o índice de Yue Clayton foi proposto em 2005, e é semelhante a um outro índice clássico em ecologia de populações, o índice de Jaccard, pois ele é usado para descrever a sobreposição de membros da comunidade entre diferentes amostras. No entanto, diferentemente de Jaccard, a abundância proporcional de cada OTU é levada em conta por Yue-Clayton, evitando com que a similaridade entre duas comunidades seja subestimada (YUE; CLAYTON, 2005). O índice também associa um número entre 0 a 1, da mesma forma que o índice de Bray-Curtis.

As triplicatas de cada testemunho foram analisadas de forma individual, e posteriormente unidas para análise entre os diferentes estratos do testemunho de solo. Sequências foram novamente agrupadas em OTUs com $97 \%$ de similaridade (cutoff de 0,03). Parks e Beiko (2013) comparando diferentes índices de $\beta$-diversidade concluíram que muitas das medidas (incluindo Bray-Curtis e Yue-Clayton) são surpreendentemente robustas em relação a escolha de cutoff usado para agrupar as OTUs (PARKS; BEIKO, 2013).

Os resultados gerados pelo cálculo dos índices de Bray-Curtis e Yue-Clayton são apresentados de forma gráfica, através de um mapa de calor (heat map), onde a escala de cor corresponde aos valores dos índices de 0 até 1 . Os heat maps foram calculados com base nos dados obtidos para os índices em cutoff de 0,03 e estão apresentados nas figuras 44 e 47. 


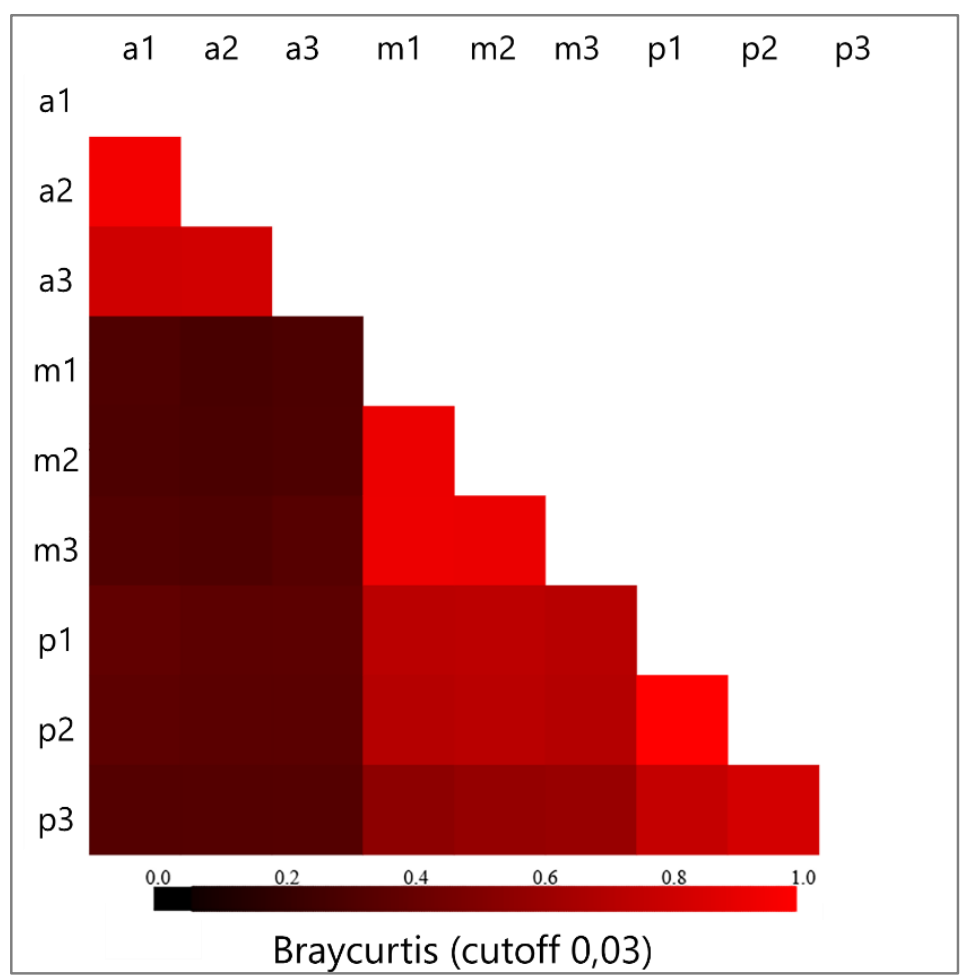

Figura 44 - Mapa de calor representando a similaridade de estrutura de comunidade das amostras de de Axel-Heiberg. Triplicatas de cada estrato foram analisadas individualmente. Amostras da camada ativa: a1, a2 e a3; as amostras de solo de transição: m1, m2 e m3; amostras do permafrost: p1, p2 e p3. Mapa calculado com o índice de similaridade de Bray-Curtis. Valor de cutoff: 0,03.

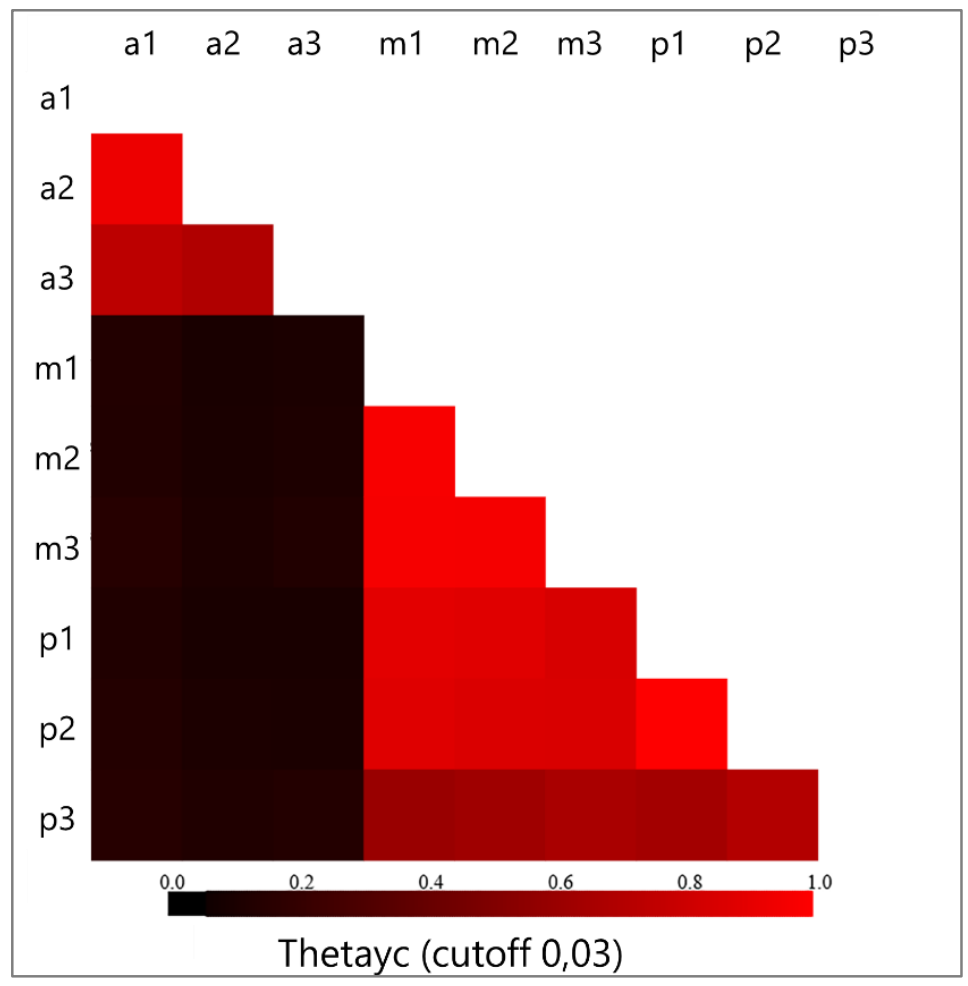

Figura 45 - Mapa de calor representando a similaridade de estrutura de comunidade das amostras de de Axel-Heiberg. Triplicatas de cada estrato foram analisadas individualmente. Amostras da camada ativa: a1, a2 e a3; as amostras de solo de transição: m1, m2 e m3; amostras do permafrost: p1, p2 e p3. Mapa calculado com o índice de similaridade Theta de Yue \& Clayton. Valor de cutoff: 0,03. 


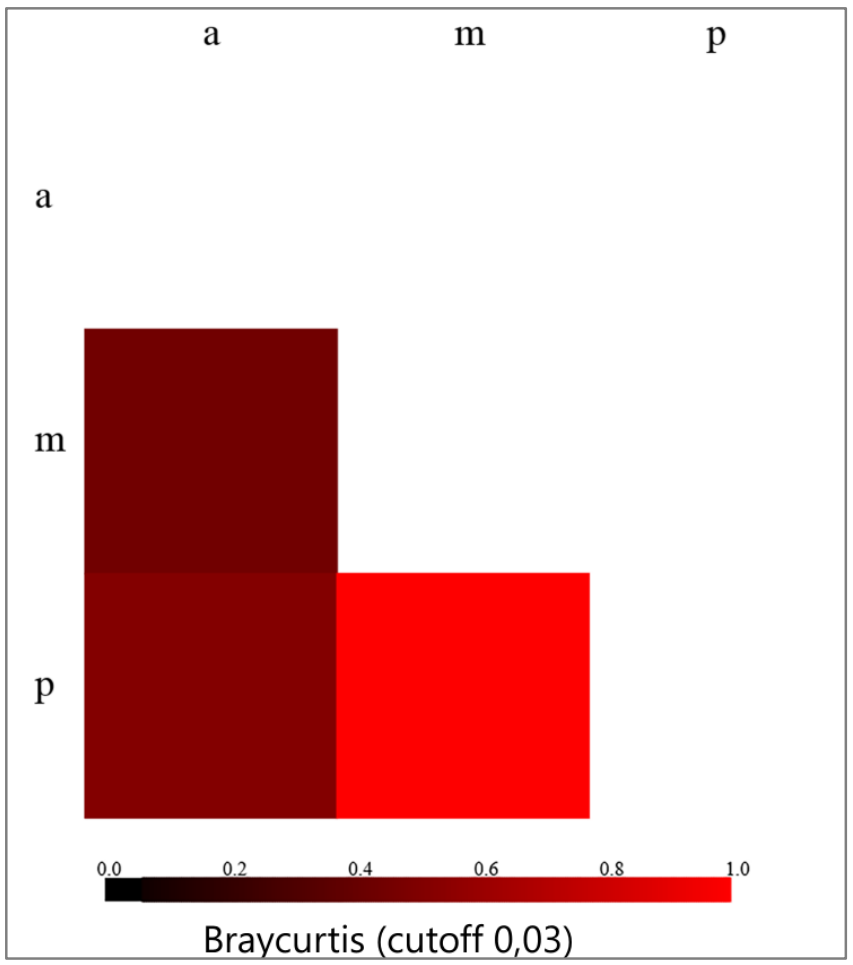

Figura 46 - Mapa de calor representando a similaridade de estrutura de comunidade das amostras de de Axel-Heiberg. Triplicatas referentes ao mesmo estrato foram unidas. Camada ativa: a;Interface: m; permafrost: p. Mapa calculado com o índice de similaridade de Bray-Curtis. Valor de cutoff: 0,03.

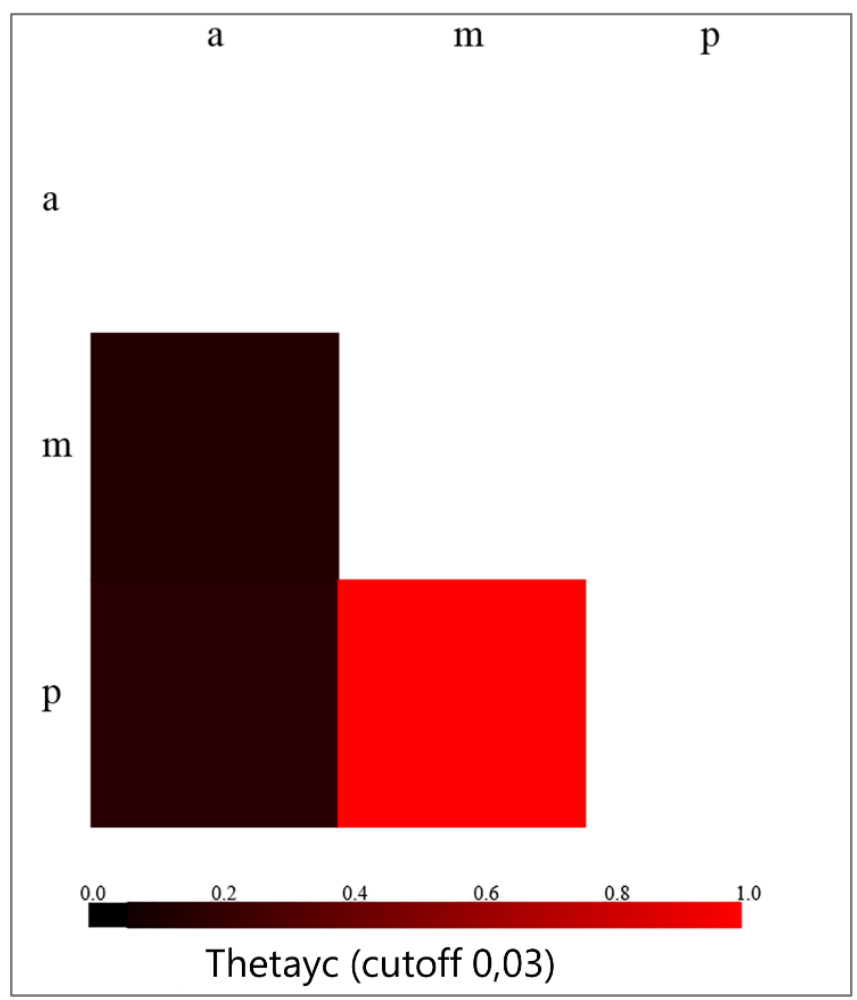

Figura 47 - Mapa de calor representando a similaridade de estrutura de comunidade das amostras de de Axel-Heiberg. Triplicatas referentes ao mesmo estrato foram unidas. Camada ativa: a; Interface: m; permafrost: p. Mapa calculado com o índice de similaridade Theta Yue \& Clayton. Valor de cutoff: 0,03. 
Os índices de Bray-Curtis e de Yue-Clayton revelaram primeiramente que as réplicas pertencentes ao mesmo estrato de solo se comportaram de forma muito similar quando comparadas com amostras provenientes de outros estratos.

Entre os diferentes estratos de solo, as amostras provenientes da camada de transição e do permafrost apresentaram maior similaridade na estrutura da comunidade. Este resultado pode ser observado pelos blocos de cor vermelho intenso (mais próximo do valor 1) nas matrizes construídas tanto a partir do índice Bray-Curtis quanto de Yue-Clayton. Ambos os índices estimaram que a camada ativa tem a composição mais distinta em relação aos outros estratos de solo. Este resultado é bastante evidente ao observar comparações de amostras da camada ativa com amostras de outras camadas gerou uma unidade de cor preta (muito próxima do valor 0) na matriz de Yue-Clayton (Figuras 45). Já pela análise de Bray-Curtis é possível notar uma similaridade ligeiramente maior entre a camada ativa e o permafrost, de forma contra intuitiva visto que a camada ativa é mais próxima da camada de transição. No entanto, este resultado está de acordo com o mostrado pela análise dos diagramas de Venn. As triplicatas referentes ao mesmo estrato do testemunho foram unidas para um novo cálculo dos índices de $\beta$-diversidade (Figuras 46 e 47), os resultados corroboraram os descritos até aqui.

\subsubsection{Composição da comunidade microbiana}

A evolução da tecnologia de sequenciamento de DNA tem permitido analisar a composição microbiana específica à cada habitat em resolução e confiança cada vez maiores. Por sua vez, a compreensão dos grupos que tendem a dominar os ambientes periglaciais terrestres é uma oportunidade para o entendimento de como a vida microbiana se adapta a esses ambientes e aos parâmetros que os definem. A partir da análise da abundância de grupos taxonômicos, em última estância se abre a possibilidade da inferência de genes e processos celulares à resistência ao frio, congelamento e dessecação.

A análise da composição da comunidade bacteriana das amostras de Axel Heiberg, foi feita por comparação com sequências depositas no banco de sequências SILVA, que possui curadoria para assegurar que apenas informações de sequência confiáveis estão incluídas em sua base de dados (PRUESSE et al., 2007; QUAST et al., 2013). Todas as 255424 sequências contíguas foram alinhadas e classificadas 
taxonomicamente com limiar de confiança (bootstrap) de no mínimo 80\% para atribuição de uma sequência à um grupo taxonômico, valor recomendado por Kozich et al. (2013).

A atribuição das sequências ao nível taxonômico de filo classificou 96,5\% das sequências, o resultado da classificação das sequências encontra-se na tabela 7. Os gráficos de abundância relativa para as 9 amostras sequenciadas encontra-se nas figuras 48, e o gráfico para abundância relativa por estrato do testemunho (unindo cada triplicata) encontra-se nas figuras 49, 50 e 51. A tabela 8, destaca a variação da abundância relativa em relação à profundidade do estrato de solo.

A classificação das sequências das amostras do testemunho de solo de Axel Heiberg apresentou um total de 33 Filos distribuídos pelos 3 estratos analisados. Deste total, os filos Actinobacteria, Chloroflexi, Proteobacteria e Acidobacteria unidos são bastante presentes em todas as amostras, representando entre 58 e $69 \%$ do total de sequências. Estes grupos vêm sendo descritos como abundantes em amostras de permafrost do Ártico (JANSSON; TAS, 2014; TAS et al., 2014; YERGEAU et al., 2010) de amostras do ártico canadense (STEVEN et al., 2007; WILHELM et al., 2012; YERGEAU et al., 2010).

Proteobacteria compõe de $10 \%$ a $17 \%$ da comunidade bactéria nas amostras estudadas sendo mais abundante nas camadas superiores. Em procariontes, este é o filo considerado o maior e fenotipicamente mais diversificado. Gupta (2000), usando métodos moleculares e procurando comparar os filos bacterianos e compreender suas relações evolutivas, inferiu que as principais mudanças evolutivas em Bacteria surgiram de modo direcional e que os filos hoje identificados evoluíram a partir de um antepassado comum culminando nos grupos que compõe as divisões modernas de Proteobacteria na seguinte ordem: Gram-positivos de baixo teor de $\mathrm{G}+\mathrm{C}$; Grampositivos de alto teor de $\mathrm{G}+\mathrm{C}$; Clostridium-Fusobacteria-Thermotoga; DeinococcusThermus-Chloroflexi; Cianobactérias; Spirochetes; Chlamydia-CytophagaBacteroides-Chlorobi; Aquifex; Proteobacteria-1 (epsilon and delta); Proteobacteria-2 (alpha) ; Proteobacteria-3 (beta) ; Proteobacteria-4 (gamma) (GUPTA, 2000; GUPTA; GRIFFITHS, 2002). De forma não surpreendente, todas as camadas do solo de Axel Heiberg estudadas possuem alta abundância de Proteobacteria. Este filo é comumente encontrado em análises de rRNA 16S originárias de amostras de solos periglaciais, que vão do permafrost do Ártico, à Antártica aonde é presente no solo árido de McMurdo Dry Valley, e bastante abundante em permafrost de Deception 
Island, gelo e solo exposto por recuo de geleira Baranowski, na llha Rei George(BLANCO et al., 2012; DUARTE, 2010; JANSSON; TAS, 2014; SMITH et al., 2006; STEVEN et al., 2007). Dentre as proteobactérias, as classes mais abundantes, no entanto, variam bastante de acordo com a amostra estudada (JANSSON; TAS, 2014).

O filo Actinobacteria compreende bactérias gram-positivas com DNA de elevado teor de G-C. Estes micro-organismos exibem uma grande variedade de morfologias e representa, em termos de número e variedade de espécies identificadas, uma das maiores unidades taxonômicas atualmente reconhecidas dentro de domínio Bacteria. Dentro de 39 famílias e 130 gêneros, o filo Actinobacteria está amplamente distribuído em ecossistemas terrestres e aquáticos, exibem também diversas propriedades fisiológicas e metabólicas, tais como a produção de enzimas extracelulares e a formação de uma grande variedade de metabólitos secundários (EMBLEY; STACKEBRANDT, 1994; GOODFELLOW; WILLIAMS, 1983). A profusão de ambientes que essas bactérias colonizam e sua alta diversidade é acompanhada por uma alta heterogeneidade genômica (VENTURA et al., 2007). Actinobacteria em especial é frequentemente reportado em abundância em amostras que vão do Alaska e Sibéria até a Antártica, e sua abundância em amostras congeladas foi associada a evidências de reparo de DNA e atividade metabólica (JANSSON; TAS, 2014; JOHNSON et al., 2007). Actinobacteria é especialmente abundante na camada ativa entre os estratos analisados, aonde corresponde por cerca de um quarto das sequências classificadas, o filo mais abundante deste estrato. Apesar de ser proporcionalmente menos significante nas amostras mais profundas, este filo é o segundo mais abundante tanto na camada de interface quanto no permafrost.

Acidobacteria é também um filo onipresente nos mais diferentes habitats do planeta. Por ser formado primariamente por bactérias não cultiváveis, foi reconhecido pela primeira vez como um novo filo recentemente, mas é atualmente classificado em 26 subdivisões filogenéticas (BARNS et al., 2007; KISHIMOTO; KOSAKO; TANO, 1991; KUSKE; BARNS; BUSCH, 1997). Este filo parece ser especialmente abundante em amostras de solo aonde corresponde por 10 a $50 \%$ dos filos detectados em análises de ecologia microbiana independentes de cultivo (JANSSEN, 2006). Esse filo também é abundante em solos certos solos periglaciais da Antártica de McMurdo Dry Valleys e em algumas amostras de permafrost siberiano e do Ártico canadense, porém tem participação pouco significativa em amostras de solo de recuo de geleira na 
Antártica e permafrost encontrados no Alaska (DUARTE, 2010; JANSSON; TAS, 2014; TAS et al., 2014). Acidobacteria foi o terceiro filo mais abundante nas amostras da camada ativa de Axel Heiberg, correspondendo a 15,4\% das sequências classificadas. Esta relevância, no entanto, se perde com a profundidade das amostras. No solo de Interface corresponde a 7,6\% das sequências, o sexto filo mais abundante. Nas amostras de solo permanentemente congelado Acidobacteria é sétimo filo mais abundante, correspondendo a $3,2 \%$ das sequências. Essa diminuição pode ser correlacionada a uma menor adaptabilidade a solos congelados do ártico, ou restrições quanto à composição físico-químico dos solos mais profundos deste ambiente.

O filo Chloroflexi, é classicamente dividido em quatro grandes subfilos, com base na comparação de similaridade por 16S rRNA, subfilos I, II, III e IV, recentemente foi proposto a adição de novos grupos como Thermomicrobia e Ktedonobacteria (HUGENHOLTZ; GOEBEL; PACE, 1998; HUGENHOLTZ; STACKEBRANDT, 2004). O que dificulta a caracterização taxonômica e fisiológica destes micro-organismos é o fato de que são em geral considerados não-cultiváveis. Apenas a classe Chloroflexi, pertencente ao subfilo III, tem sido rotineiramente cultivada em laboratório. Parte dos "não-cultiváveis", o Subfilo I possui a maior diversidade dentro de Chloroflexi, representado cerca de $70 \%$ das sequências deste filo depositadas RDP (YAMADA; SEKIGUCHI, 2009). Mais recentemente, no entanto, foi descrito o isolamento de cepas de Thermomicrobia e cepas aeróbias e anaeróbias do Subfilo I, caracterizadas por organismos de crescimento lento e por vezes dependentes da associação com outros micro-organismos para seu crescimento (RAPPÉ; GIOVANNONI, 2003; SEKIGUCHI et al., 2001; YAMADA et al., 2007). Foi com o avanço das técnicas de ecologia microbiana independente de cultivo que a profundidade filogenética de Chloroflexi foi melhor assimilada e comparada até mesmo com Proteobacteria (DOJKA; HARRIS; PACE, 2000). Sua ampla distribuição foi reconhecida com a descrição de grupos pertencentes a este táxon em uma variedade de ambientes naturais, o que sugere um papel ecológico importante nesses ecossistemas. Chloroflexi tem sido reportado como um dos filos dominantes em habitats que vão dos mais variados tipos de solo, oceano, rios, lagos até habitats considerados extremos como vários sedimentos de mar profundo, hot-springs e lagos hipersalinos (FRY et al., 2008; YAMADA; SEKIGUCHI, 2009). Em ambientes periglaciais, esse filo representou uma parcela significativa em amostras de solo e sedimento da Antártica analisadas 
por pirosequenciamento (DUARTE, 2010; FRANCO, 2014). Outros estudos confirmam a abundância de Chloroflexi em solos de permafrost, sendo que nenhuma das sequências pertencentes a este filo tem estreita semelhanças com as poucas cepas cultiváveis de Chloroflexi (JANSSON; TAS, 2014). Neste estudo, o filo Chloroflexi tornou-se mais abundante com a profundidade, passando de $14 \%$ na camada ativa para $26 \%$ na camada de transição e $36 \%$ do total de sequências no permafrost.

Entre os filos menos abundantes, vale destacar que o filo Planctomycetes perde relevância com a profundidade, da camada ativa ao permafrost, passando de $7 \%$ para $6 \%$ e $2 \%$ respectivamente. O Filo Gemmatimonadetes que passa de apenas $2 \%$ do total de sequências na camada ativa para $12 \%$ e $9 \%$ nas camadas mais profundas. Verrucomicrobia com comportamento similar, atingindo o pico de abundância na camada intermediária com 8,6\% (o quinto mais abundante neste estrato). Já o Bacteroidetes é menos abundante na camada intermediária com 3,1\% de todas as sequências classificadas em filos, $4,1 \%$ na camada ativa e 5,8\% no permafrost. 
Tabela 7 - Número de sequências de Axel Heiberg classificadas em cada Filo a partir da ferramenta Classifier (RDP).

\begin{tabular}{|c|c|c|c|c|c|c|c|c|c|}
\hline \multirow{2}{*}{ Filo } & \multicolumn{9}{|c|}{ Amostras } \\
\hline & a1 & a2 & a3 & m1 & $\mathrm{m} 2$ & m3 & p1 & p2 & p3 \\
\hline Acidobacteria & 5385 & 6611 & 4545 & 1278 & 2112 & 1396 & 819 & 1068 & 823 \\
\hline Actinobacteria & 9773 & 8722 & 6443 & 2260 & 3285 & 2432 & 4998 & 5488 & 5420 \\
\hline Armatimonadetes & 1559 & 1418 & 1464 & 180 & 218 & 197 & 186 & 182 & 189 \\
\hline Bacteroidetes & 977 & 1803 & 1646 & 305 & 1147 & 490 & 786 & 1171 & 2957 \\
\hline BD1-5 & 3 & 0 & 0 & 8 & 9 & 0 & 5 & 9 & 15 \\
\hline Candidate_division_BRC1 & 3 & 1 & 2 & 2 & 0 & 7 & 2 & 2 & 0 \\
\hline Candidate_division_OD1 & 134 & 116 & 124 & 531 & 1094 & 370 & 441 & 495 & 1467 \\
\hline Candidate_division_OP11 & 0 & 1 & 2 & 15 & 22 & 7 & 18 & 10 & 33 \\
\hline Candidate_division_OP3 & 3 & 2 & 0 & 6 & 22 & 11 & 0 & 2 & 3 \\
\hline Candidate_division_OP8 & 0 & 0 & 0 & 0 & 0 & 0 & 3 & 0 & 0 \\
\hline Candidate_division_TM7 & 1232 & 1588 & 1573 & 208 & 494 & 224 & 351 & 536 & 939 \\
\hline Candidate_division_WS3 & 0 & 1 & 0 & 1 & 8 & 2 & 0 & 4 & 3 \\
\hline Candidate_division_WS6 & 6 & 0 & 0 & 12 & 16 & 9 & 3 & 2 & 0 \\
\hline Chlamydiae & 19 & 27 & 32 & 17 & 27 & 38 & 12 & 10 & 21 \\
\hline Chlorobi & 0 & 0 & 0 & 5 & 0 & 8 & 0 & 0 & 0 \\
\hline Chloroflexi & 4999 & 5510 & 4190 & 3948 & 7598 & 4700 & 7913 & 12203 & 10755 \\
\hline Cyanobacteria & 321 & 447 & 468 & 11 & 30 & 13 & 60 & 110 & 10 \\
\hline Deinococcus-Thermus & 1 & 0 & 0 & 0 & 0 & 1 & 0 & 1 & 0 \\
\hline Elusimicrobia & 11 & 15 & 14 & 24 & 55 & 14 & 21 & 14 & 43 \\
\hline Fibrobacteres & 2 & 1 & 0 & 4 & 13 & 3 & 7 & 5 & 6 \\
\hline Firmicutes & 13 & 13 & 10 & 30 & 42 & 38 & 160 & 256 & 269 \\
\hline Fusobacteria & 0 & 0 & 0 & 0 & 0 & 0 & 5 & 3 & 0 \\
\hline Gemmatimonadetes & 586 & 593 & 612 & 1843 & 4036 & 1801 & 2790 & 2904 & 1730 \\
\hline Nitrospirae & 0 & 0 & 2 & 11 & 11 & 10 & 2 & 1 & 16 \\
\hline NPL-UPA2 & 0 & 0 & 0 & 0 & 2 & 0 & 0 & 0 & 0 \\
\hline Planctomycetes & 1846 & 1710 & 3543 & 1070 & 1711 & 1196 & 519 & 679 & 580 \\
\hline Proteobacteria & 5412 & 5707 & 7388 & 2070 & 3402 & 2067 & 2020 & 2871 & 3963 \\
\hline SHA-109 & 4 & 5 & 1 & 5 & 10 & 8 & 1 & 3 & 1 \\
\hline SM2F11 & 19 & 9 & 4 & 122 & 278 & 88 & 63 & 47 & 41 \\
\hline TM6 & 22 & 12 & 9 & 0 & 3 & 5 & 0 & 4 & 13 \\
\hline unclassified & 1329 & 1168 & 1180 & 466 & 1030 & 749 & 690 & 947 & 1499 \\
\hline Verrucomicrobia & 475 & 704 & 1807 & 1272 & 2315 & 1821 & 897 & 910 & 1186 \\
\hline WCHB1-60 & 209 & 234 & 194 & 17 & 57 & 35 & 43 & 74 & 87 \\
\hline WD272 & 608 & 375 & 557 & 117 & 130 & 95 & 51 & 48 & 26 \\
\hline
\end{tabular}




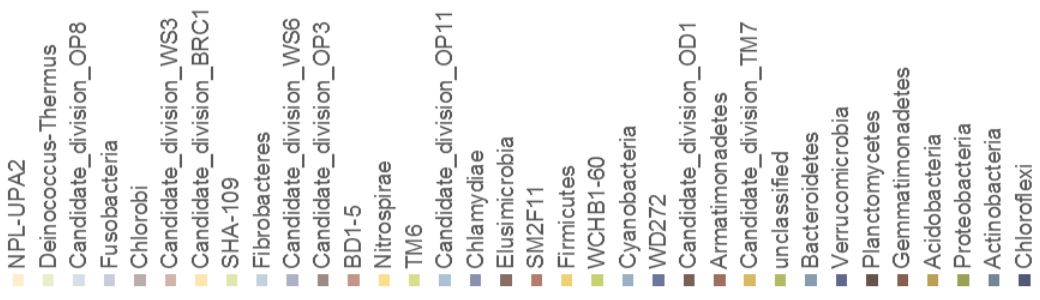

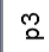

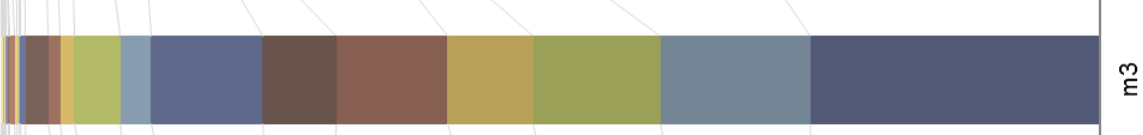

过

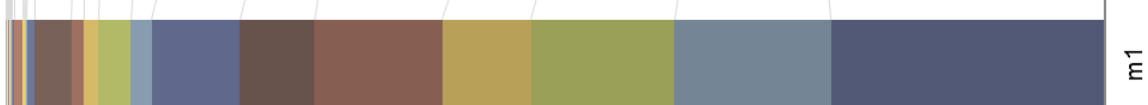

$\bar{E}$

$\frac{\pi}{\pi}$

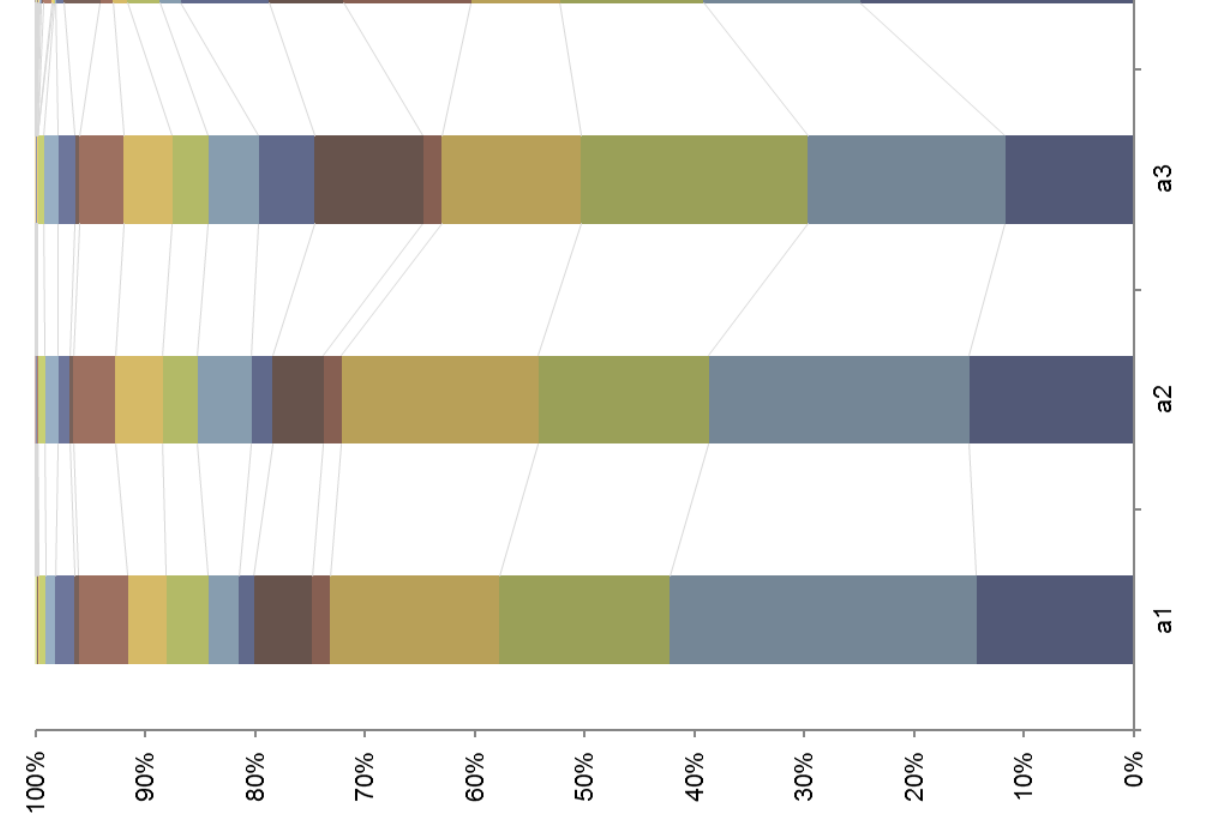

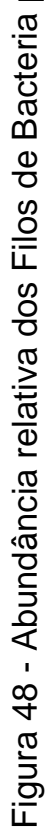



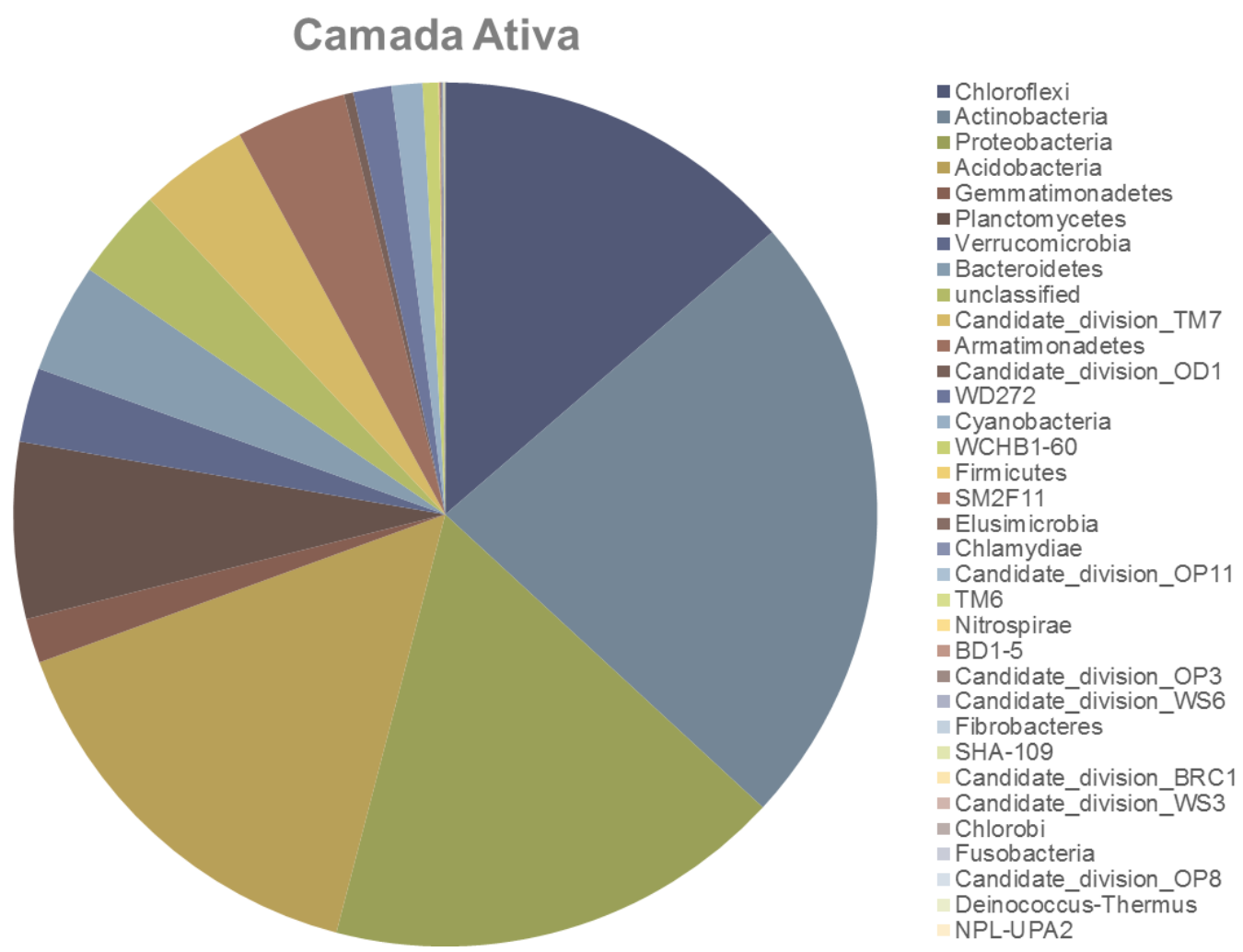

Figura 49 - Abundância relativa dos Filos de Bacteria no estrato da camada ativa do testemunho de solo de Axel-Heiberg.
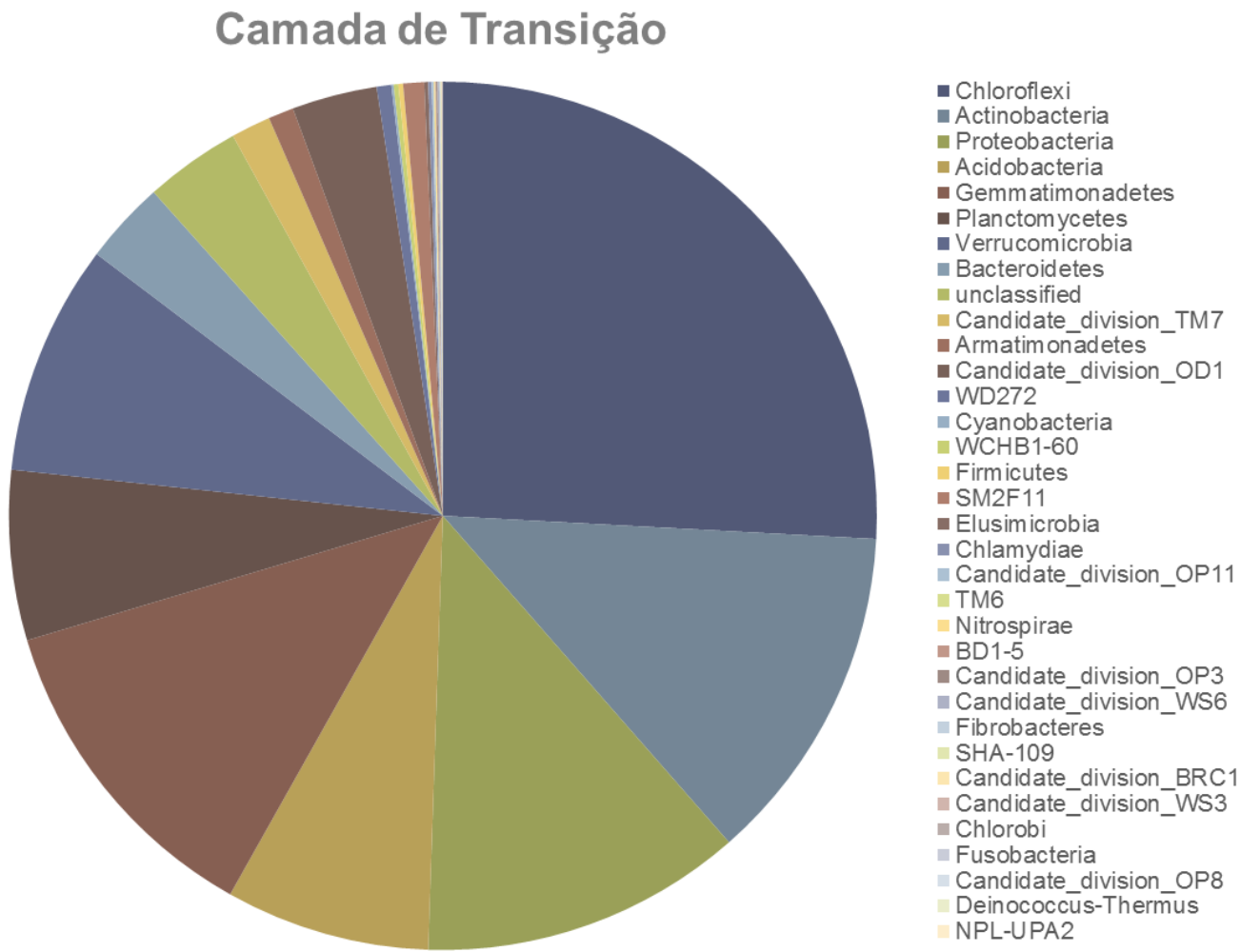

Figura 50 - Abundância relativa dos Filos de Bacteria no estrato da camada de transição do testemunho de solo de Axel-Heiberg. 


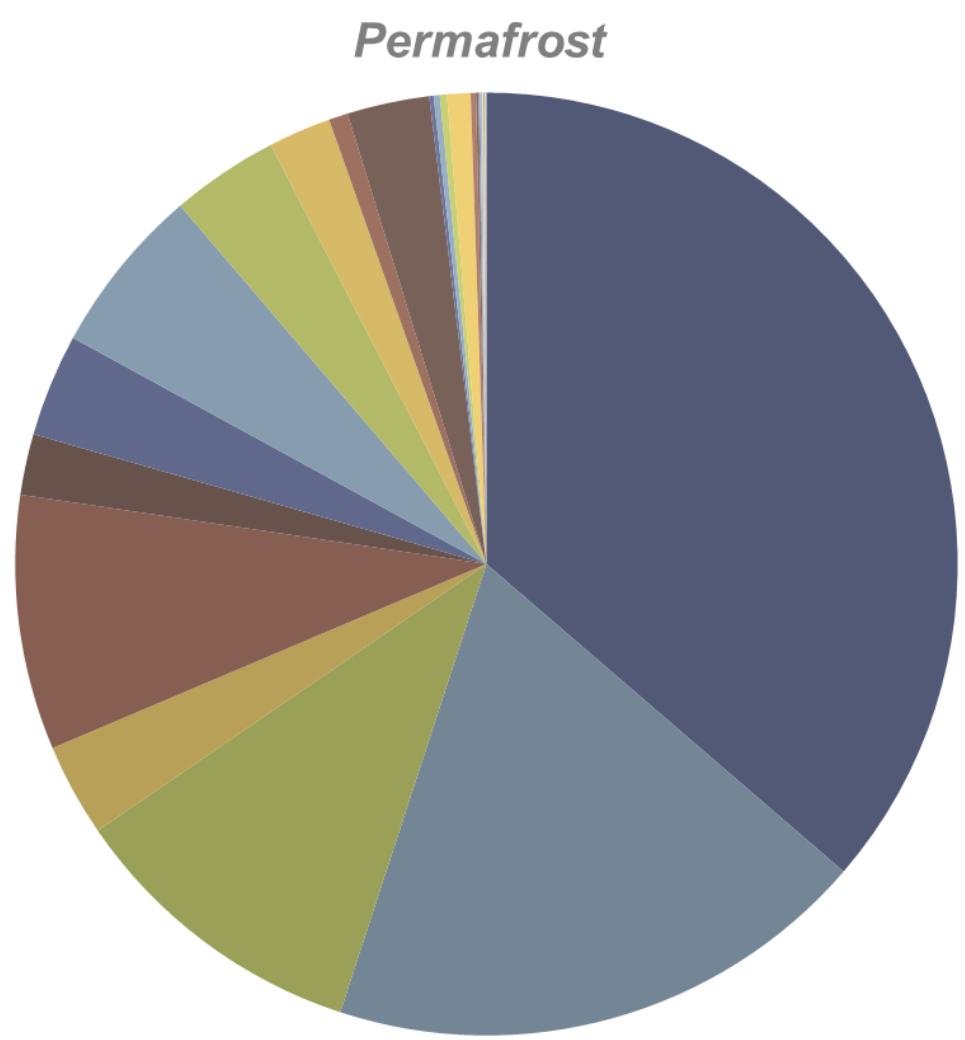

- Chloroflexi

Actinobacteria

- Proteobacteria

- Acidobacteria

- Gemmatimonadetes

- Planctomycetes

- Verrucomicrobia

Bacteroidetes

- unclassified

- Candidate_division_TM7

- Armatimonadetes

- Candidate_division_OD1

- WD272

Cyanobacteria

WCHB1-60

Firmicutes

SM2F11

- Elusimicrobia

- Chlamydiae

- Candidate_division_OP11

TM6

Nitrospirae

BD1-5

-Candidate_division_OP3

- Candidate_division_WS6

Fibrobacteres

SHA-109

Candidate division_BRC1

- Candidate_division_WS3

- Chlorobi

Fusobacteria

Candidate division_OP8

Deinococcus-Thermus

NPL-UPA2

Figura 51 - Abundância relativa dos Filos de Bacteria no estrato do permafrost do testemunho de solo de Axel-Heiberg. 
Tabela 8 - Variação da abundância relativa dos 15 filos mais abundantes em relação à profundidade do estrato de solo.

\begin{tabular}{lccc}
\hline & Camada ativa & Interface & Permafrost \\
\hline Chloroflexi & $13,7 \%$ & $25,8 \%$ & $36,3 \%$ \\
Actinobacteria & $23,2 \%$ & $12,7 \%$ & $18,7 \%$ \\
Proteobacteria & $17,2 \%$ & $12,0 \%$ & $10,4 \%$ \\
Acidobacteria & $15,4 \%$ & $7,6 \%$ & $3,2 \%$ \\
Gemmatimonadetes & $1,7 \%$ & $12,2 \%$ & $8,7 \%$ \\
Planctomycetes & $6,6 \%$ & $6,3 \%$ & $2,1 \%$ \\
Verrucomicrobia & $2,8 \%$ & $8,6 \%$ & $3,5 \%$ \\
Bacteroidetes & $4,1 \%$ & $3,1 \%$ & $5,8 \%$ \\
Candidate_division_TM7 & $4,1 \%$ & $1,5 \%$ & $2,1 \%$ \\
Armatimonadetes & $4,1 \%$ & $0,9 \%$ & $0,7 \%$ \\
Candidate_division_OD1 & $0,3 \%$ & $3,2 \%$ & $2,8 \%$ \\
WD272 & $1,4 \%$ & $0,5 \%$ & $0,1 \%$ \\
Cyanobacteria & $1,1 \%$ & $0,1 \%$ & $0,2 \%$ \\
WCHB1-60 & $0,6 \%$ & $0,2 \%$ & $0,2 \%$ \\
Firmicutes & $0,0 \%$ & $0,2 \%$ & $0,8 \%$ \\
\hline
\end{tabular}

A classificação completa das sequências pertencentes aos 10 filos mais abundantes em suas respectivas classes, esta detalhada no Apêndice A, e dos 8 filos mais abundantes, apresentado na figura 52. Seguindo a tendência dos resultados anteriormente apresentados, a variação maior se dá na passagem da camada ativa para a camada de interface. Vale notar que a estrutura da comunidade também não varia radicalmente de um estrato para outro. Dentre os 4 filos que dominam mais da metade da comunidade de todas as amostras, o filo Chloroflexi destaca-se pela grande diversidade de classes encontradas (16 classes), sendo as mais abundantes as representadas por micro-organismos não cultiváveis. A classe JG37-AG-4, de Chloroflexi é dominante dentro, no permafrost e camada de transição, e, por conseguinte, é a mais abundante entre todas as classes de todos os filos classificados pelo RDP, o que sugere uma grande adaptabilidade deste táxon aos solos congelados de Axel Heiberg. Actinobacteria, é o filo mais abundante na camada ativa influenciado pela grande presença da classe Actinobacteria, essa classe sofre grande redução da nas camadas mais profundas acarretando na perda de abundância do filo como um todo. A classe Thermoleophilia por sua vez, apresentou cerca de duas vezes mais sequências na camada de permafrost. Em Proteobacteria, apenas a classes das 
Epsilonproteobacteria não teve presença significativa na composição do filo. A classe Alphaproteobacteria é dominante nas camadas ativa e de interface. No permafrost essa dominância é dividida com a classe das Betaproteobactérias, que parece ganhar relevância nos solos congelados. Acidobacteria apresentou baixa diversidade de classes com apenas duas entre as sequências classificadas. A composição da comunidade apresenta mudança notável entre a camada ativa e de transição com o filo Holophagae dividindo espaço com a antes quase que inteiramente dominante Acidobacteria. Não é notada diferença na estrutura de Acidobacteria entre esta última camada e o permafrost. 


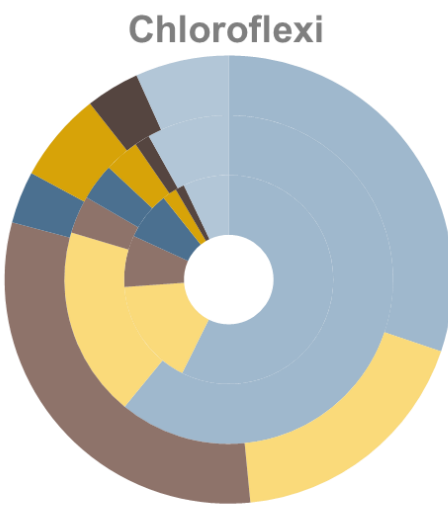

JG37-AG-4

KD4-96

- Ktedonobacteria

- Gitt-GS-136

- TK10

- Chloroflexia

outros

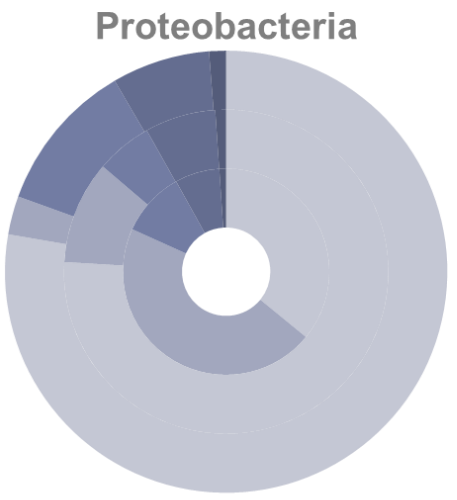

Alphaproteobacteria

- Betaproteobacteria

- Gammaproteobacteria

- Deltaproteobacteria

unclassified
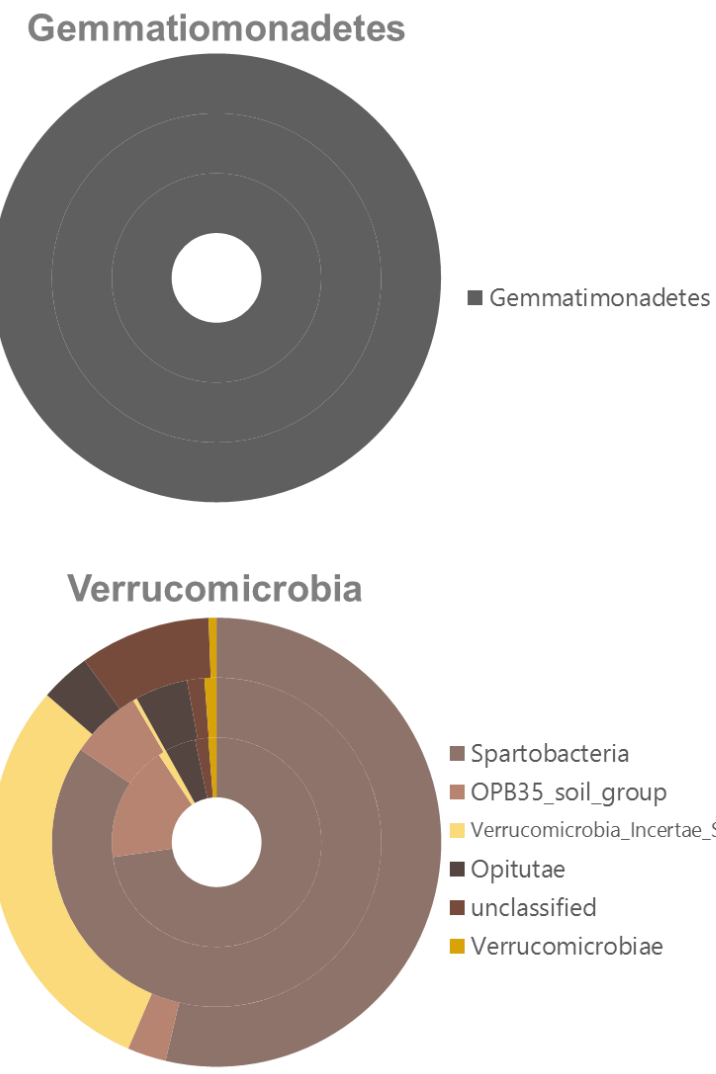

- Spartobacteria

- OPB35_soil_group

- Verrucomicrobia_Incertae_S

- Opitutae

unclassified

- Verrucomicrobiae

Figura 52 - Composição taxonômica ao nível de Classe dos 8 filos mais abundantes encontrados nas amostras de Axel Heiberg. Disco externo: Camada ativa; Disco intermediário: Camada de interface; Disco interno: Permafrost. 
O efeito do valor de corte (bootstrap) para classificação de sequências no RDP, em diferentes níveis taxonômicos, foi investigado por Bacci et al. (2015) usando reads provenientes do sistema Illumina. Como esperado, o aumento do valor de bootstrap leva a uma diminuição no número de sequências atribuídas. Ao classificar reads de 300 pb da região V3 do rRNA 16S usando um limiar de bootstrap igual a 0,8, a porcentagem de reads classificadas foi de cerca de $15 \%$ a nível de família e $5 \%$ no nível de gênero. Para um bootstrap consideravelmente mais permissivo de 0,5 a porcentagem de sequências classificadas passa para cerca de 30\% a nível de família e $20 \%$ no nível de gênero (BACCl et al., 2015).

Para a classificação das contigs de Axel-Heiberg foi usado um bootstrap de $80 \%$, recomendado pelo grupo que desenvolve o software mothur dentro do protocolo de curadoria para sequências provenientes do sequenciador Illumina MiSeq (KOZICH et al., 2013). Pressupõe-se que o tamanho médio das contigs (de cerca de 430 pb), o alto número de sequências obtidas pela tecnologia de NGS e qualidade das sequências pós tratamento para redução de erros, incentive a utilização de um bootstrap mais rigoroso. A parcela das contigs classificadas ao nível de família foi de $60 \%$ para a camada ativa, $46 \%$ para a camada intermediária e $42 \%$ para o permafrost (Figuras 53 a 55). Já a porcentagem de contigs classificadas ao nível de gênero de $36 \%$ para a camada ativa, $19 \%$ para a camada intermediária e $21 \%$ para o permafrost (Figuras 56 a 58). Amostras de permafrost apresentaram o maior número de sequências não-classificadas, possivelmente por representar uma ecologia microbiana relativamente desconhecida, de famílias conservadas por milhares de anos no solo congelado e, portanto, com menos sequências depositadas nos bancos de dados usados como referência. Como discutido esse valor seria maior em caso de utilização de limiar mais baixo de bootstrap, porém as custas de uma menor confiabilidade na designação taxonômica das sequências. No entanto, esse valor foi superior ao encontrado por Bacci et al. (2005), provavelmente pelos motivos já destacados: tamanho médio das sequências superior e tratamento para redução de erros. Ao todo 128003 contigs foram atribuídas a uma família enquanto 70961 contigo foram atribuídas a algum gênero depositado no banco de dados do RDP.

A classificação das sequências ao nível de família para as 9 amostras estudadas encontra-se na Apêndice $B$ enquanto a abundância relativa é mostrada na figura 53. 


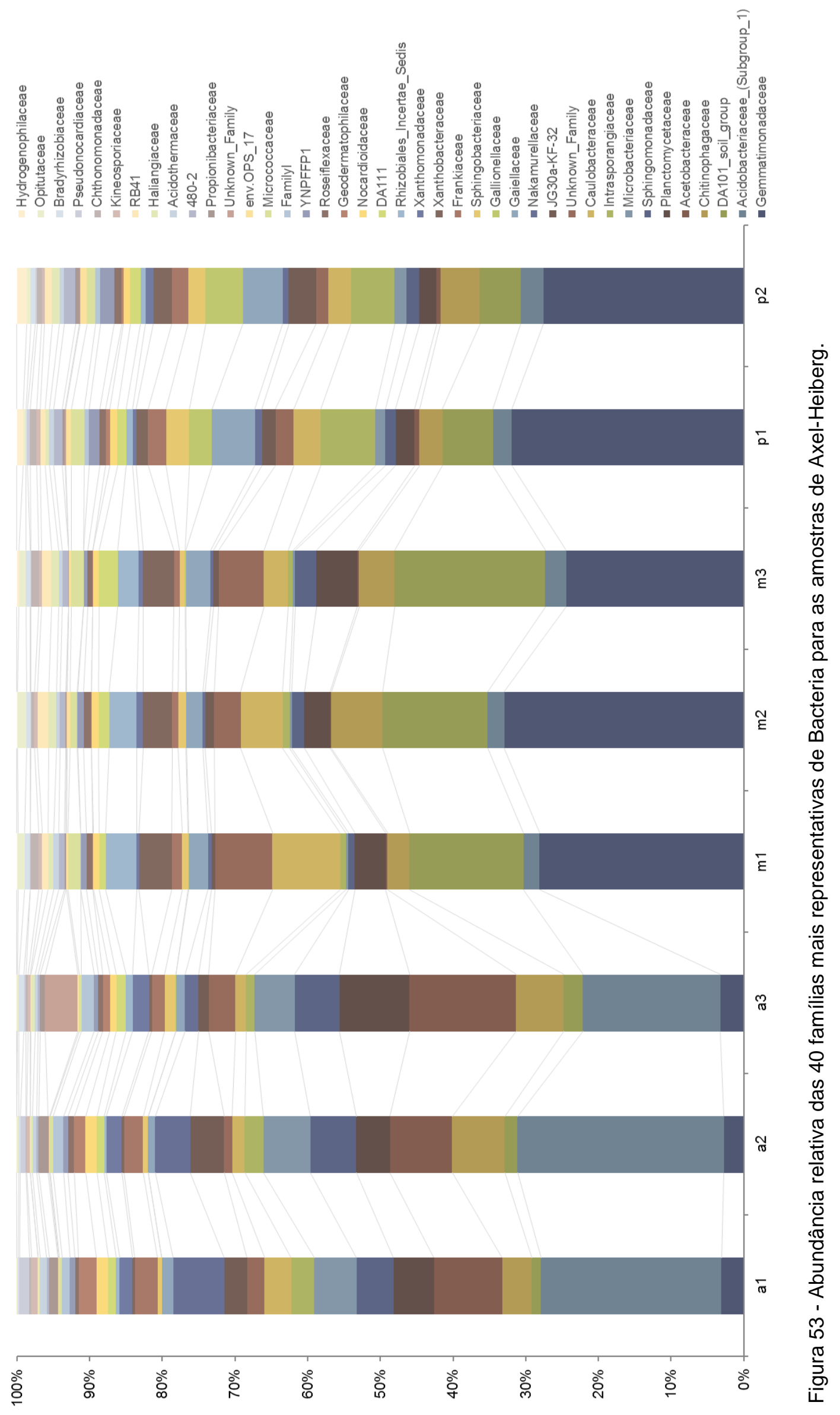



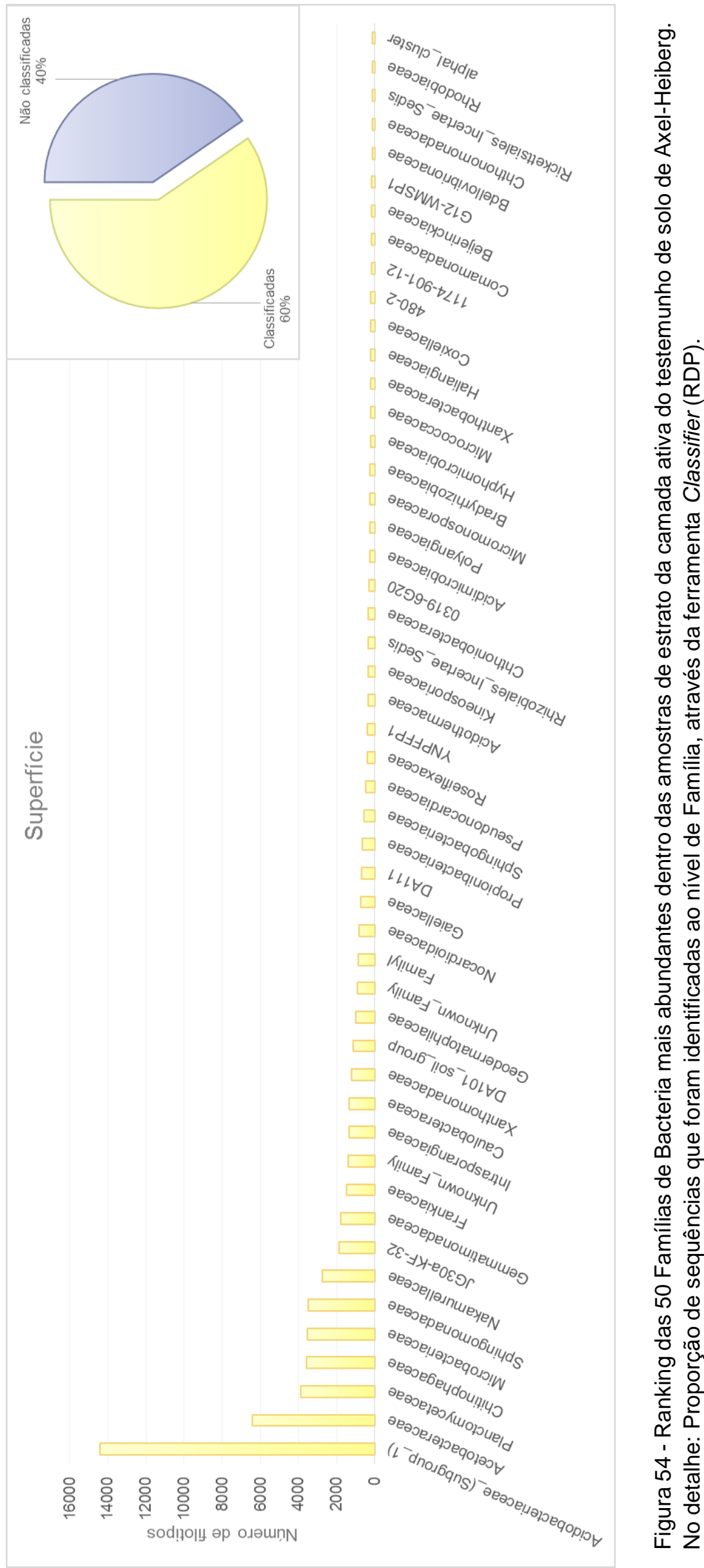


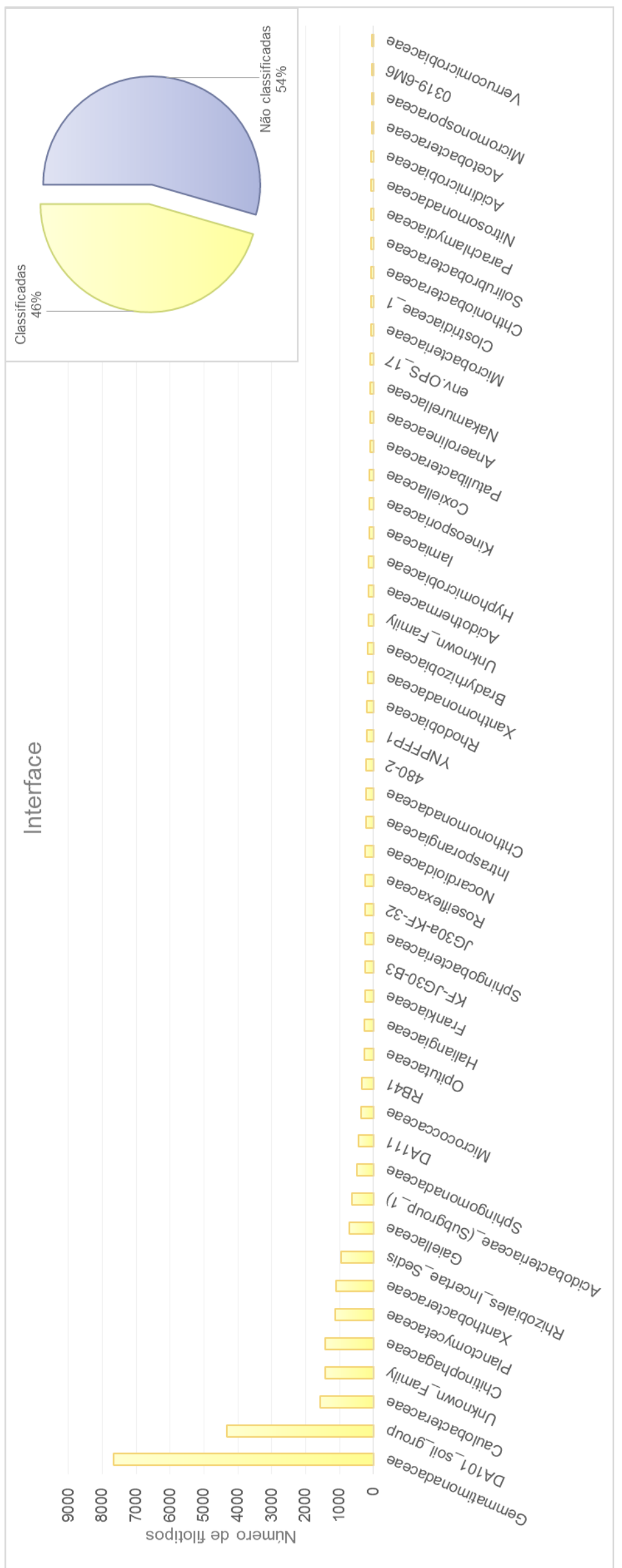

운

몽 

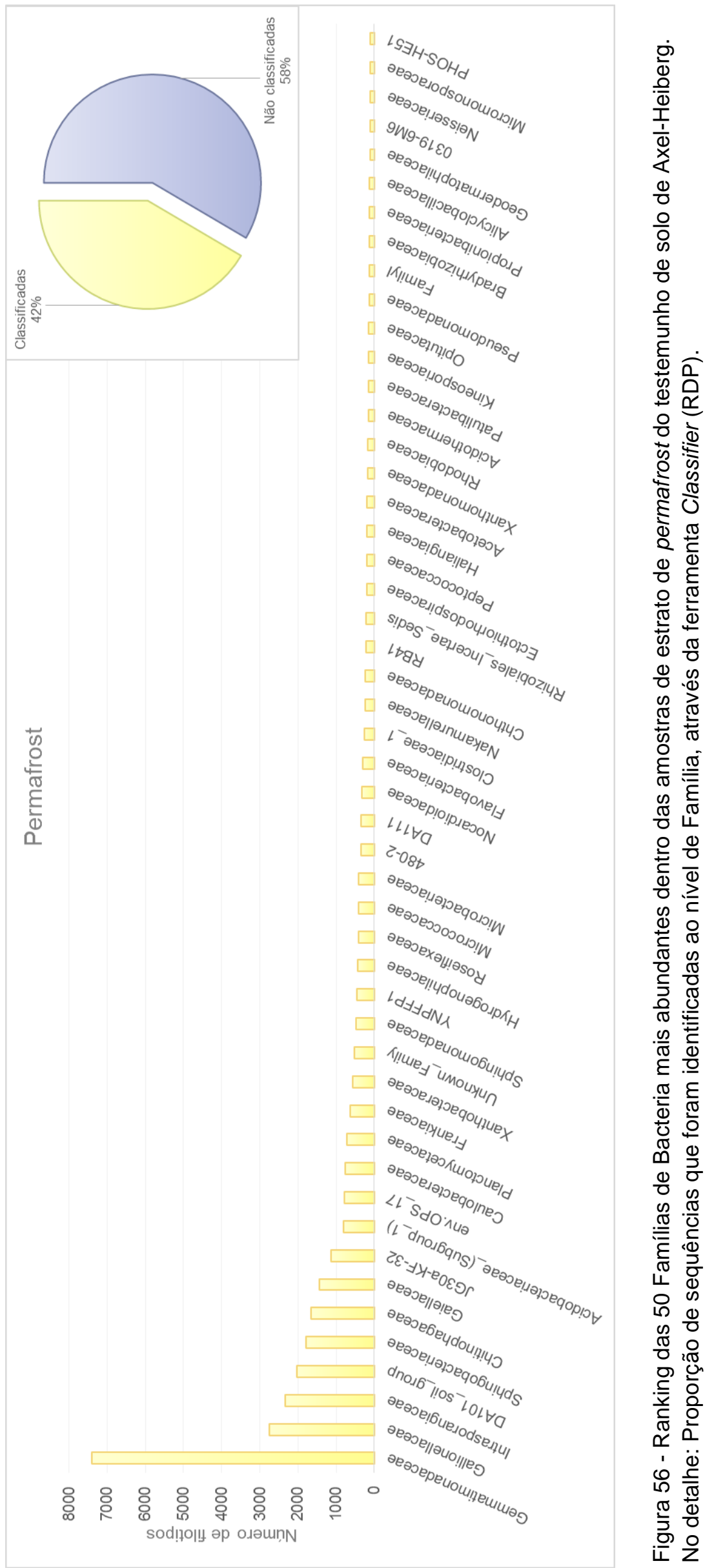
A classificação das sequências ao nível de gênero para as 9 amostras estudadas encontra-se no Apêndice $C$ enquanto a abundância relativa dos 40 genêros mais representativos é mostrada na figura 57 . Os gêneros mais abundantes para cada estrato de solo são apresentados nas figuras 58 a 60.

A proporção de sequências não classificadas em níveis taxonômicos mais específicos, dificulta o desdobramento dos filos mais importantes em suas famílias e gêneros. Espera-se que a maioria dos gêneros classificados seja de gêneros com representantes "cultiváveis". As sequências classificadas em Chloroflexi, o filo mais abundante entre todas as contigs classificadas, com 61816 sequências foram atribuídas majoritariamente à famílias e gêneros desconhecidos. Apenas 8 famílias foram identificadas, atribuídas a 1561 sequências. Dentre estas famílias apenas 6 gêneros foram identificados, 5 destes gêneros possuem menos de 5 sequências, enquanto o gênero Roseiflexus foi atribuído a 1049 sequências, o restante não pode ser classificado a nenhum gênero. A abundância de famílias e gêneros classificados tem utilidade como indicador da mudança na estrutura da comunidade. Existe uma mudança mais pronunciada entre amostras ao se observar táxons mais profundos. 

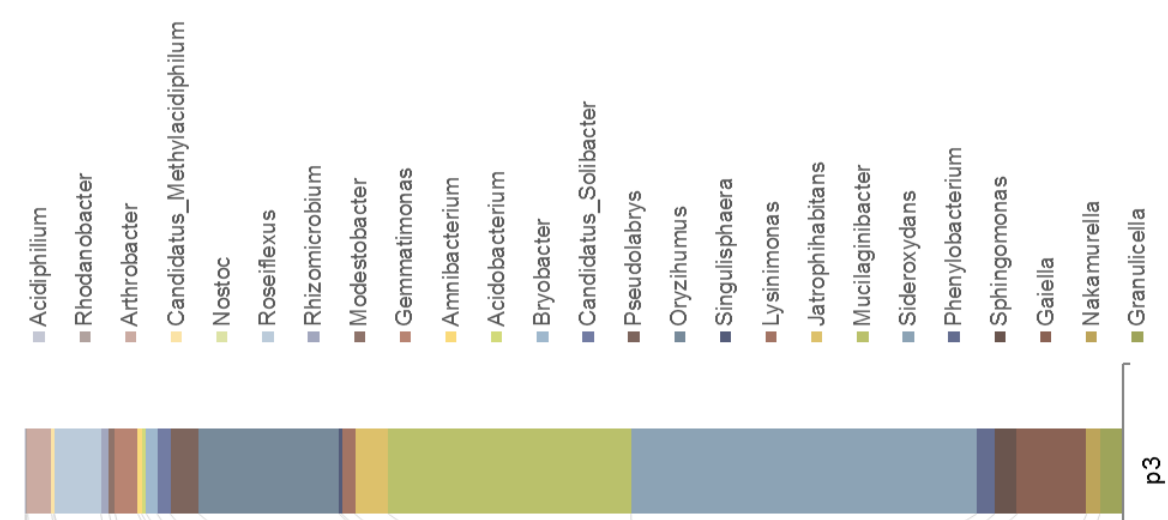

ำ

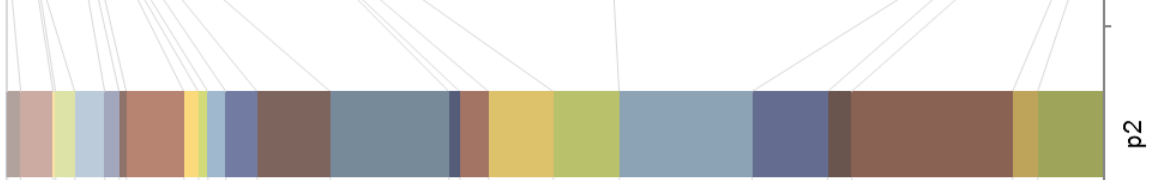

$\frac{0}{0}$
$\frac{0}{0}$
$\frac{0}{1}$
$\frac{1}{0}$
$\frac{0}{2}$
0
0
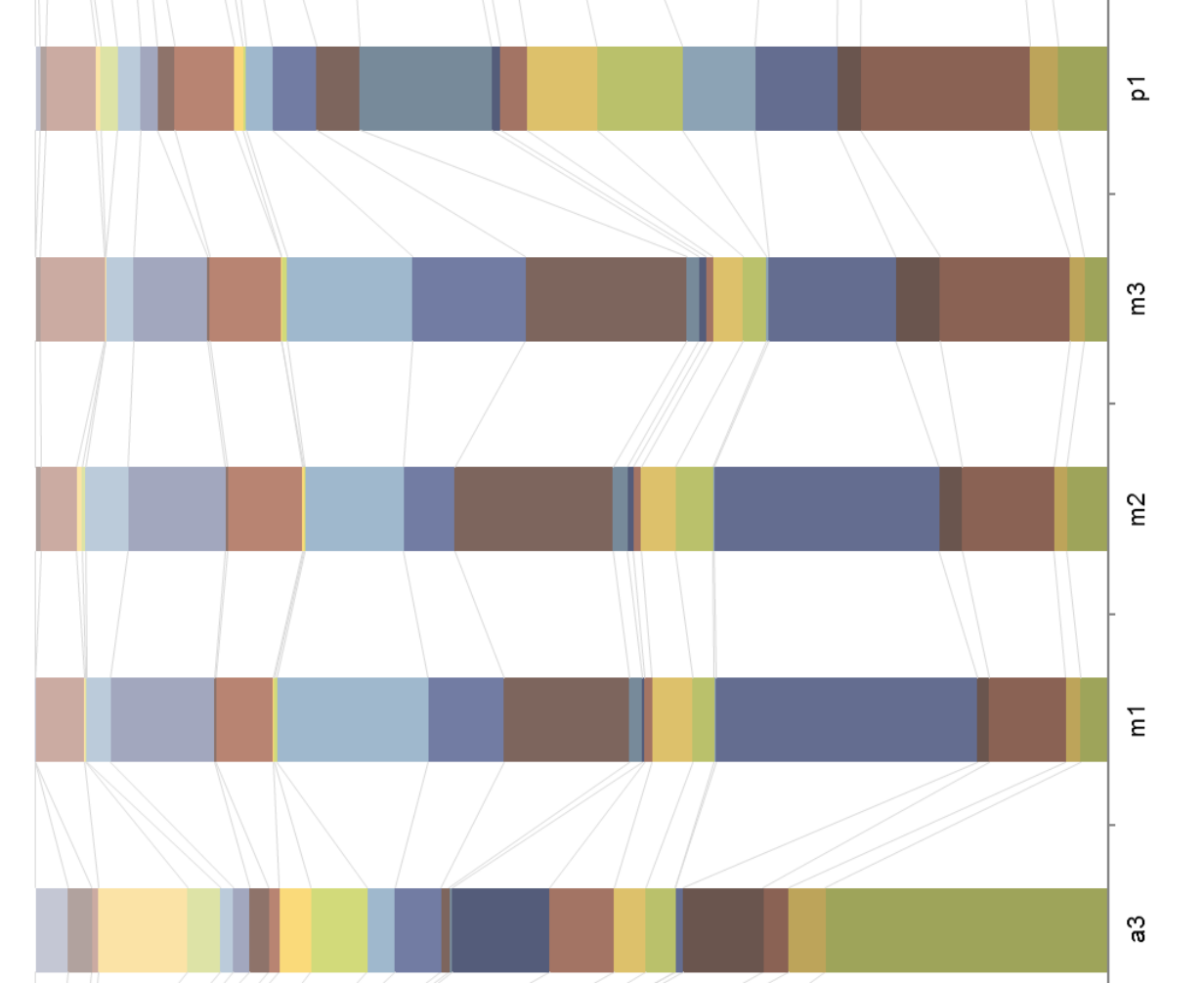

ᄋ

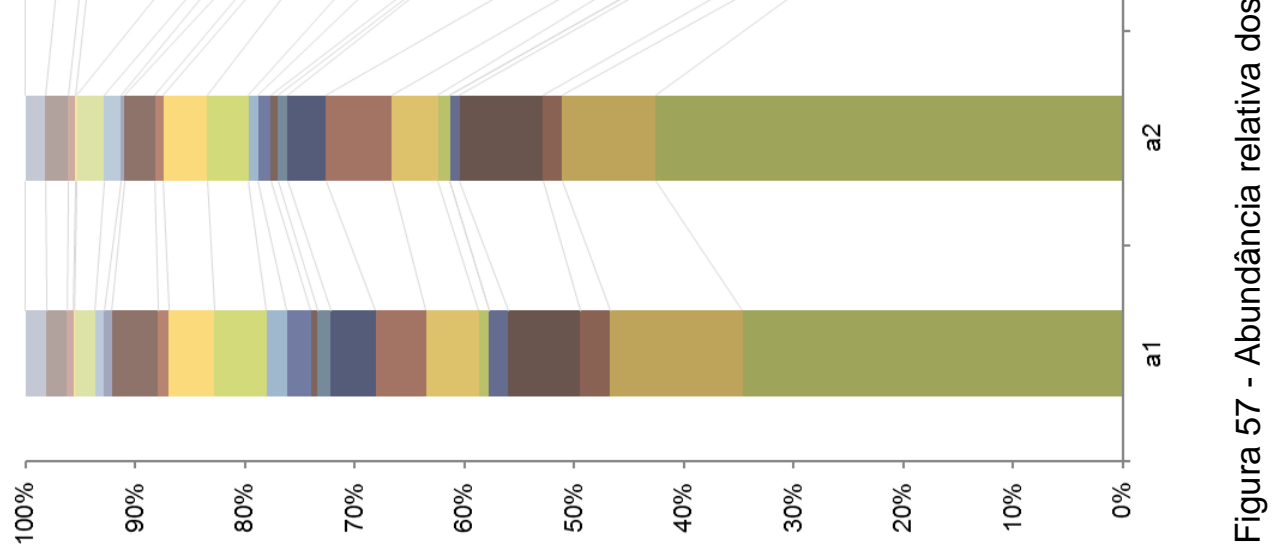




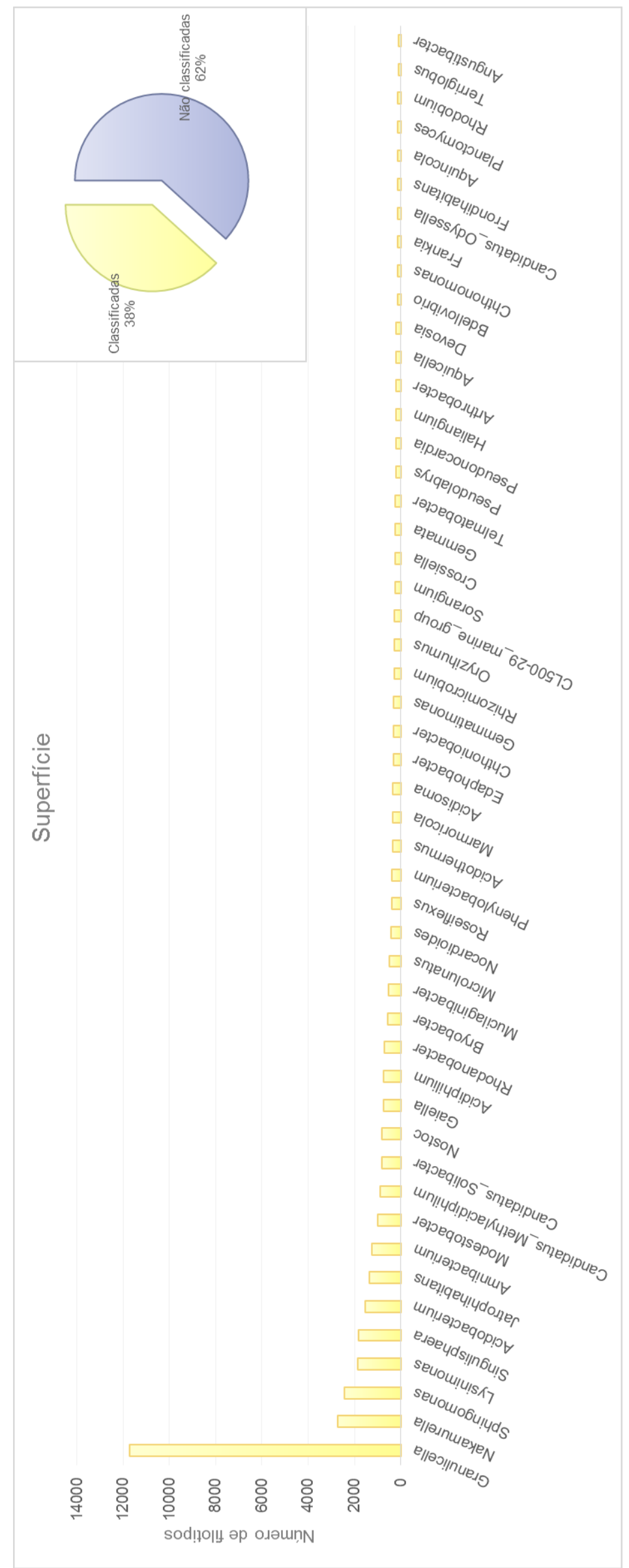




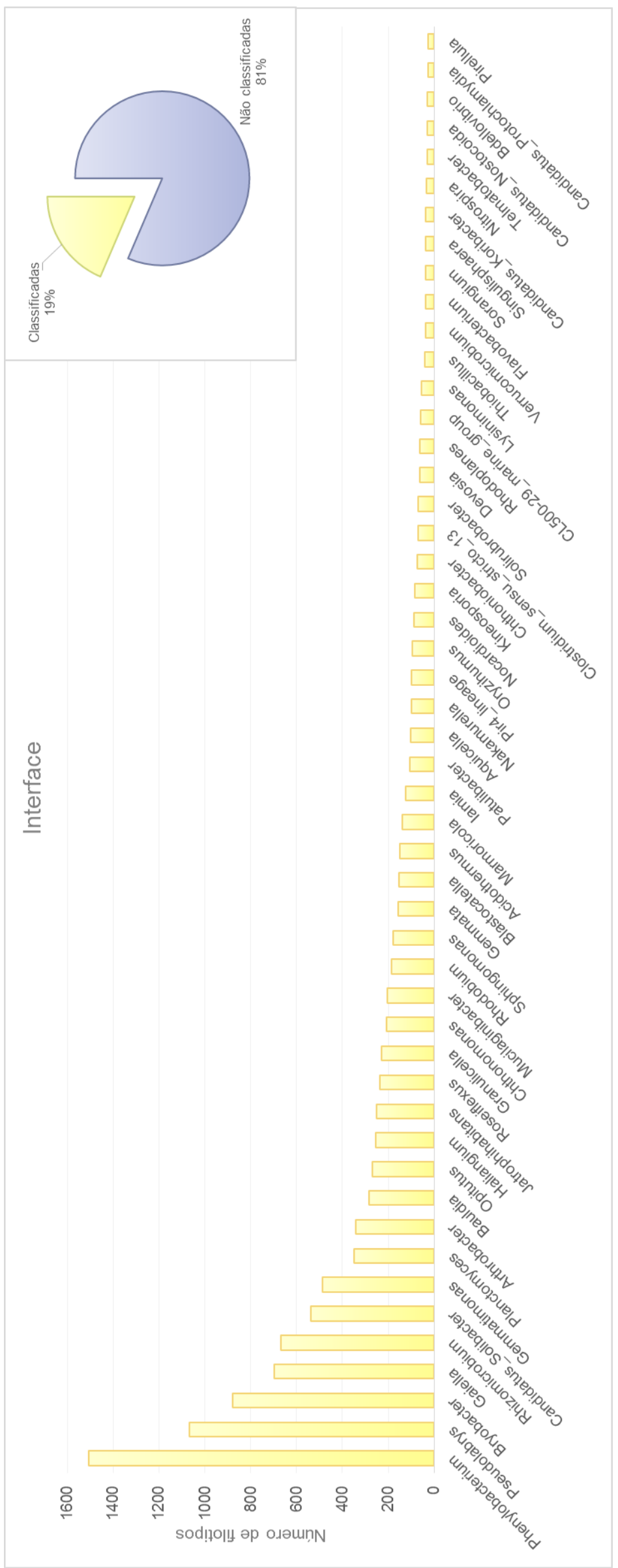

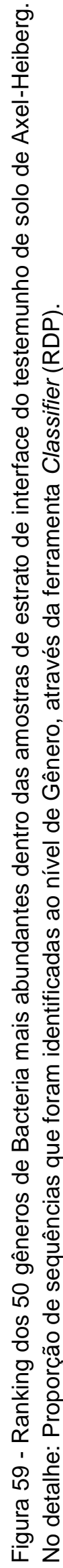



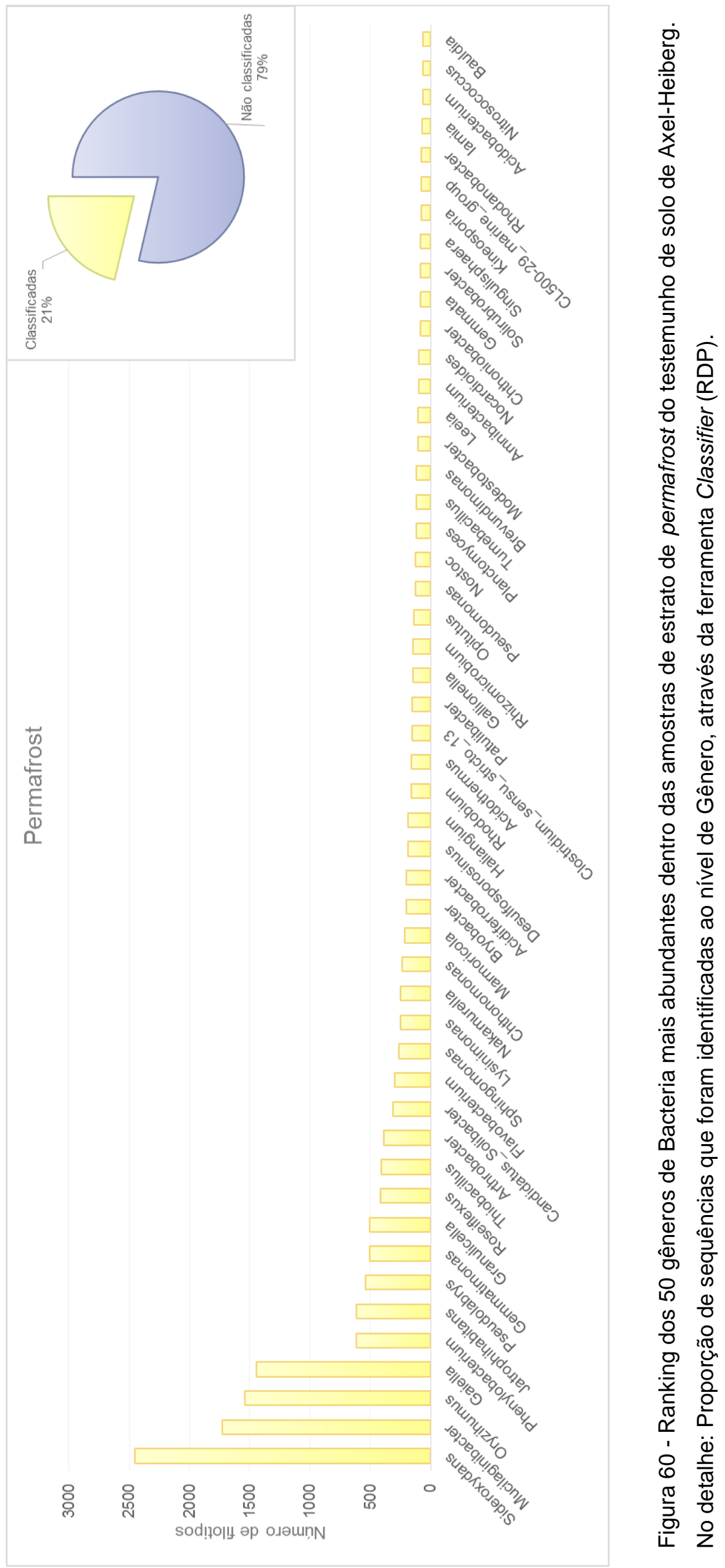
4.4.6 Análise comparativa entre os resultados de isolamento e sequenciamento das amostras de Axel Heiberg

Neste trabalho, na seção 4.3, foi descrita a prospecção de bactérias de ambientes periglaciais resistentes à dessecação. As amostras do testemunho de solo do Ártico canadense usadas para o isolamento foram as mesmas utilizadas para a análise da comunidade bacteriana por sequenciamento de DNA de alto rendimento, detalhadas na presente seção. Todas as cepas isoladas de amostras do testemunho de solo de Axel-Heiberg pertencem ao filo Firmicutes, distribuídas entre as famílias Planococcaceae e Paenibacillaceae. Enquanto que das amostras originárias da Antártica, não analisadas em relação a sua ecologia microbiana neste estudo, foram isoladas bactérias do filo Actinobacteria, família Micrococcaceae e filo Proteobacteria, família Moraxellaceae.

A reação de amplificação em tempo real, uma variante da reação de PCR convencional, seria a técnica mais indicada para a identificação e determinação quantitativa do número de cópias de rRNA 16 específicas para esses taxa. No entanto, o uso dessa técnica seria dependente do uso de marcadores moleculares específicos e padronização das reações. Os resultados provenientes do sequenciamento massivo por NGS descritos aqui, possibilita também, pelo alto número de sequências obtidas e classificação taxonômica com alto grau de confiabilidade, a presença destes grupos de micro-organismos nas amostras estudadas. As tabelas 9 e 10, apresentam os resultados das sequências de Axel Heiberg classificadas nas famílias dos organismos isolados e seus gêneros mais próximos. Observa-se que a abundância dos grupos pertencentes aos isolados do Ártico é bastante baixa. A família Micrococcus, isolada das amostras de Deception Island, Antártica, é mais abundante, sendo uma das 50 famílias mais presentes dentre as sequências classificadas. Essa família, no entanto, não foi isolada das amostras do Ártico, talvez pela baixa abundância do gênero Micrococcus nessa comunidade.

O experimento de isolamento de resistentes à dessecação procurou eliminar com tratamento por clorofórmio, todos os micro-organismos não adaptados ao estresse hídrico. Seria de certa forma esperado que os isolados não se correlacionem com os grupos mais abundantes da comunidade. Esse resultado também reforça a tese de que a parcela de bactérias cultiváveis com o uso de técnicas de isolamento 
padrão é pequeno comparado com o universo de grupos microbianos encontrados em uma dada comunidade.

Tabela 9 - Sequências pertencentes à Famílias de micro-organismos resistentes à dessecação isoladas ao longo deste trabalho, presentes nas amostras de Axel Heiberg.

\begin{tabular}{lcccccc}
\hline \multirow{2}{*}{ Família } & \multicolumn{2}{c}{ Superfície } & \multicolumn{2}{c}{ Interface } & \multicolumn{2}{c}{ Permafrost } \\
\cline { 2 - 7 } & № Seqs & Abundância & № Seqs & Abundância & № Seqs & Abundância \\
\hline Micrococcaceae & 221 & $0,20548 \%$ & 355 & $0,56484 \%$ & 409 & $0,48106 \%$ \\
Moraxellaceae & 1 & $0,00093 \%$ & 1 & $0,00159 \%$ & 1 & $0,00118 \%$ \\
Planococcaceae & 2 & $0,00186 \%$ & 0 & $0,00000 \%$ & 7 & $0,00823 \%$ \\
Paenibacillaceae & 2 & $0,00186 \%$ & 6 & $0,00955 \%$ & 14 & $0,01647 \%$ \\
Total de seqs. & 107554 & $100 \%$ & 62850 & $100 \%$ & 85020 & $100 \%$ \\
\hline
\end{tabular}

Tabela 10 - Sequências pertencentes à gêneros próximos aos micro-organismos resistentes à dessecação isoladas ao longo deste trabalho, presentes nas amostras de Axel Heiberg.

\begin{tabular}{lcccccc}
\hline \multirow{2}{*}{ Gênero } & \multicolumn{2}{c}{ Superfície } & \multicolumn{2}{c}{ Interface } & \multicolumn{2}{c}{ Permafrost } \\
\cline { 2 - 7 } & № Seqs & Abundância & № Seqs & Abundância & № Seqs & Abundância \\
\hline Micrococcus & 0 & $0,00000 \%$ & 0 & $0,00000 \%$ & 0 & $0,00000 \%$ \\
Psychrobacter & 1 & $0,00132 \%$ & 0 & $0,00000 \%$ & 1 & $0,00138 \%$ \\
Sporosarcina & 1 & $0,00132 \%$ & 0 & $0,00000 \%$ & 3 & $0,00415 \%$ \\
Paenibacillus & 2 & $0,00265 \%$ & 5 & $0,00923 \%$ & 14 & $0,01937 \%$ \\
Total de seqs. & 75604 & $100 \%$ & 54196 & $100 \%$ & 72260 & $100 \%$ \\
\hline
\end{tabular}




\section{CONCLUSÕES}

\subsection{Adaptações de E. antarcticum à variação térmica}

Exiguobacterium antarcticum possui um mecanismo de adaptação ao frio que envolve a expressão diferencial de diversas proteínas. Foi detectada alterações na expressão de diversas chaperonas, caracterizadas por modular a estrutura e integridade de macromoléculas, e proteínas relacionadas ao metabolismo oxidativo da bactéria, indicando a repressão do metabolismo aeróbico em baixas temperaturas. As adaptações fisiológicas de E. antarcticum à temperatura são também acompanhadas por alterações que se mostraram significativas em seu fenótipo, definida pela redução da superfície celular em células cultivadas a $0 \stackrel{\circ}{ } \mathrm{C}$.

\subsection{Tolerância de E. antarcticum à parâmetros físicos de ambientes simulados}

Os experimentos de simulação de ambientes extraterrestres indicaram que tanto a bactéria Exiguobacterium antarcticum quanto a bactéria Planococcus halocryophillus não possuem elevada resistência à radiação ambiental presente na superfície da Terra e ultravioleta de vácuo (UV-V). Essas bactérias sobreviveriam por pouco tempo no espaço interplanetário ou na superfície de Marte.

\subsection{Isolamento e tolerância à dessecação de micro-organismos polares}

Cepas de micro-organismos pela primeira vez foram isoladas de amostras do Ártico canadense e da Antártica utilizando clorofórmio como um meio para selecionar micro-organimos tolerantes à dessecação. Esta abordagem foi capaz de isolar com sucesso bactérias formadoras e não formadoras de esporos, com uma tendência ao isolamento de bactérias Gram-positivas.

A tolerância à dessecação foi afetada pela solução em que as células foram suspensas antes da secagem; meio R2B se mostrou mais protetor do que a água. Mais da metade das linhagens isoladas sobreviveram mesmo após 50 dias de dessecação. Algumas cepas mostraram resistência à dessecação comparável a bactéria Deinococcus radiodurans um dos organismos modelos utilizados na astrobiologia. 
Micro-organismos filogeneticamente próximos podem ter uma tolerância à dessecação díspar. Linhagens do mesmo gênero, porém isolados de diferentes amostras, mostraram resultados diferentes quanto a resistência à anidrobiose. Microorganismos com alta tolerância à dessecação pertencentes a diferentes famílias microbianas indicam que esta abordagem também pode ser adequada para 0 isolamento de cepas com meios de adaptação contrastantes. Estes novos isolados podem também servir de modelo em experimentos futuros em astrobiologia, em experimentos de simulação a condições extraterrestres realizadas na Terra e no espaço, em que a resistência à dessecação é uma necessidade.

\subsection{Diversidade microbiana em testemunho de solo do Ártico canadense}

A diversidade e riqueza de espécies microbianas presentes no permafrost de Axel Heiberg, Canadá, foi menor do que em estratos superiores (camada ativa e solo de interface). Os filos Actinobacteria, Chloroflexi, Proteobacteria e Acidobacteria compreenderam a maior parte das sequências identificadas. A variação da abundância de um filo não necessariamente se mostrou correlacionada com a profundidade do solo. Amostras provenientes da camada de transição e do permafrost apresentaram maior similaridade quanto à estrutura da comunidade microbiana, compartilhando maior número de espécies. 


\section{REFERÊNCIAS*}

ABREVAYA, X. C.; PAULINO-LIMA, I. G.; GALANTE, D.; RODRIGUES, F.; MAUAS, P. J. D.; CORTON, E.; LAGE, C. D. S. Comparative survival analysis of Deinococcus radiodurans and the Haloarchaea Natrialba magadii and Haloferax volcanii exposed to vacuum ultraviolet irradiation. Astrobiology, v. 11, n. 10, p. 1034-1040, 2011.

AMANN, R. I.; LUDWIG, W.; SCHLEIFER, K.-H. Phylogenetic identification and in situ detection of individual microbial cells without cultivation. Microbiological Reviews, v. 59, n. 1, p. 143169, 1995.

ANDERSON, J. D.; LAU, E. L.; SJOGREN, W. L.; SCHUBERT, G.; MOORE, W. B. Europa's differentiated internal structure: Inferences from two Galileo encounters. Science, v. 276, n. 5316, p. 1236-1239, 1997.

AYALA-DEL-RIO, H. L.; CHAIN, P. S.; GRZYMSKI, J. J.; PONDER, M. A.; IVANOVA, N.; BERGHOLZ, P. W.; DI BARTOLO, G.; HAUSER, L.; LAND, M.; BAKERMANS, C.; RODRIGUES, D.; KLAPPENBACH, J.; ZARKA, D.; LARIMER, F.; RICHARDSON, P.; MURRAY, A.; THOMASHOW, M.; TIEDJE, J. M. The genome sequence of Psychrobacter arcticus 273-4, a psychroactive siberian permafrost bacterium, reveals mechanisms for adaptation to low-temperature growth. Applied and Environmental Microbiology, v. 76, n. 7, p. 2304-2312, 2010.

BACCI, G.; BANI, A.; BAZZICALUPO, M.; CECCHERINI, M. T.; GALARDINI, M.; NANNIPIERI, P.; PIETRAMELLARA, G.; MENGONI, A. evaluation of the performances of ribosomal database project (RDP) classifier for taxonomic assignment of 16S rRNA metabarcoding sequences generated from Illumina-Solexa NGS. Journal of Genomics, v. 3, p. 36-39, 2015.

BAKER, P. E.; MCREATH, I. 1970 Volcanic eruption at Deception-Island. Nature-Physical Science, v. 231, n. 18, p. 5-9, 1971.

BAKERMANS, C.; TSAPIN, A. I.; SOUZA-EGIPSY, V.; GILICHINSKY, D. A.; NEALSON, K. H. Reproduction and metabolism at- $10 \mathrm{C}$ of bacteria isolated from Siberian permafrost. Environmental Microbiology, v. 5, n. 4, p. 321-326, 2003.

BARBOSA, H. P. M. Análise Transcriptômica da expressão diferencial térmica de Exiguobacterium antarcticum linhagem B7. 2012. (Tese de Doutorado). Genética e Biologia Molecular, Universidade Federal do Pará, Belém, 2012.

BARNS, S. M.; CAIN, E. C.; SOMMERVILLE, L.; KUSKE, C. R. Acidobacteria phylum sequences in uranium-contaminated subsurface sediments greatly expand the known diversity within the phylum. Applied and Environmental Microbiology, v. 73, n. 9, p. 3113-3116, 2007.

\footnotetext{
" De acordo com:

ASSOCIAÇÃO BRASILEIRA DE NORMAS TÉCNICAS. NBR 6023: informação e documentação: referências: elaboração. Rio de Janeiro, 2002.
} 
BAUERMEISTER, A.; MOELLER, R.; REITZ, G.; SOMMER, S.; RETTBERG, P. Effect of relative humidity on Deinococcus radiodurans' resistance to prolonged desiccation, heat, ionizing, germicidal, and environmentally relevant UV radiation. Microbial Ecology, v. 61, n. 3, p. 715722, 2011.

BENTLEY, D. R.; BALASUBRAMANIAN, S.; SWERDLOW, H. P.; SMITH, G. P.; MILTON, J.; BROWN, C. G.; HALL, K. P.; EVERS, D. J.; BARNES, C. L.; BIGNELL, H. R.; BOUTELL, J. M.; BRYANT, J.; CARTER, R. J.; CHEETHAM, R. K.; COX, A. J.; ELLIS, D. J.; FLATBUSH, M. R.; GORMLEY, N. A.; HUMPHRAY, S. J.; IRVING, L. J.; KARBELASHVILI, M. S.; KIRK, S. M.; LI, H.; LIU, X.; MAISINGER, K. S.; MURRAY, L. J.; OBRADOVIC, B.; OST, T.; PARKINSON, M. L.; PRATT, M. R.; RASOLONJATOVO, I. M. J.; REED, M. T.; RIGATTI, R.; RODIGHIERO, C.; ROSS, M. T.; SABOT, A.; SANKAR, S. V.; SCALLY, A.; SCHROTH, G. P.; SMITH, M. E.; SMITH, V. P.; SPIRIDOU, A.; TORRANCE, P. E.; TZONEV, S. S.; VERMAAS, E. H.; WALTER, K.; WU, X.; ZHANG, L.; ALAM, M. D.; ANASTASI, C.; ANIEBO, I. C.; BAILEY, D. M. D.; BANCARZ, I. R.; BANERJEE, S.; BARBOUR, S. G.; BAYBAYAN, P. A.; BENOIT, V. A.; BENSON, K. F.; BEVIS, C.; BLACK, P. J.; BOODHUN, A.; BRENNAN, J. S.; BRIDGHAM, J. A.; BROWN, R. C.; BROWN, A. A.; BUERMANN, D. H.; BUNDU, A. A.; BURROWS, J. C.; CARTER, N. P.; CASTILLO, N.; CATENAZZI, M. C. E.; CHANG, S.; COOLEY, R. N.; CRAKE, N. R.; DADA, O. O.; DIAKOUMAKOS, K. D.; DOMINGUEZ-FERNANDEZ, B.; EARNSHAW, D. J.; EGBUJOR, U. C.; ELMORE, D. W.; ETCHIN, S. S.; EWAN, M. R.; FEDURCO, M.; FRASER, L. J.; FAJARDO, K. V. F.; FUREY, W. S.; GEORGE, D.; GIETZEN, K. J.; GODDARD, C. P.; GOLDA, G. S.; GRANIERI, P. A.; GREEN, D. E.; GUSTAFSON, D. L.; HANSEN, N. F.; HARNISH, K.; HAUDENSCHILD, C. D.; HEYER, N. I.; HIMS, M. M.; HO, J. T.; HORGAN, A. M.; HOSCHLER, K.; HURWITZ, S.; IVANOV, D. V.; JOHNSON, M. Q.; JAMES, T.; JONES, T. A. H.; KANG, G.-D.; KERELSKA, T. H.; KERSEY, A. D.; KHREBTUKOVA, I.; KINDWALL, A. P.; KINGSBURY, Z.; KOKKOGONZALES, P. I.; KUMAR, A.; LAURENT, M. A.; LAWLEY, C. T.; LEE, S. E.; LEE, X.; LIAO, A. K.; LOCH, J. A.; LOK, M.; LUO, S.; MAMMEN, R. M.; MARTIN, J. W.; MCCAULEY, P. G.; MCNITT, P.; MEHTA, P.; MOON, K. W.; MULLENS, J. W.; NEWINGTON, T.; NING, Z.; NG, B. L.; NOVO, S. M.; O'NEILL, M. J.; OSBORNE, M. A.; OSNOWSKI, A.; OSTADAN, O.; PARASCHOS, L. L.; PICKERING, L.; PIKE, A. C.; PIKE, A. C.; PINKARD, D. C.; PLISKIN, D. P.; PODHASKY, J.; QUIJANO, V. J.; RACZY, C.; RAE, V. H.; RAWLINGS, S. R.; RODRIGUEZ, A. C.; ROE, P. M.; ROGERS, J.; BACIGALUPO, M. C. R.; ROMANOV, N.; ROMIEU, A.; ROTH, R. K.; ROURKE, N. J.; RUEDIGER, S. T.; RUSMAN, E.; SANCHES-KUIPER, R. M.; SCHENKER, M. R.; SEOANE, J. M.; SHAW, R. J.; SHIVER, M. K.; SHORT, S. W.; SIZTO, N. L.; SLUIS, J. P.; SMITH, M. A.; SOHNA, J. E. S.; SPENCE, E. J.; STEVENS, K.; SUTTON, N.; SZAJKOWSKI, L.; TREGIDGO, C. L.; TURCATTI, G.; VANDEVONDELE, S.; VERHOVSKY, Y.; VIRK, S. M.; WAKELIN, S.; WALCOTT, G. C.; WANG, J.; WORSLEY, G. J.; YAN, J.; YAU, L.; ZUERLEIN, M.; ROGERS, J.; MULLIKIN, J. C.; HURLES, M. E.; MCCOOKE, N. J.; WEST, J. S.; OAKS, F. L.; LUNDBERG, P. L.; KLENERMAN, D.; DURBIN, R.; SMITH, A. J. Accurate whole human genome sequencing using reversible terminator chemistry. Nature, v. 456, n. 7218, p. 53-59, 2008.

BILLI, D.; POTTS, M. Life and death of dried prokaryotes. Research in Microbiology, v. 153, n. 1, p. 7-12, 2002.

BLANCO, Y.; PRIETO-BALLESTEROS, O.; GÓMEZ, M. J.; MORENO-PAZ, M.; GARCÍAVILLADANGOS, M.; RODRÍGUEZ-MANFREDI, J. A.; CRUZ-GIL, P.; SÁNCHEZ-ROMÁN, M.; RIVAS, L. A.; PARRO, V. Prokaryotic communities and operating metabolisms in the surface and the 
permafrost of Deception Island (Antarctica). Environmental Microbiology, v. 14, n. 9, p. 24952510, 2012.

BLAXTER, M.; MANN, J.; CHAPMAN, T.; THOMAS, F.; WHITTON, C.; FLOYD, R.; ABEBE, E. Defining operational taxonomic units using DNA barcode data. Philosophical Transactions of the Royal Society B: Biological Sciences, v. 360, n. 1462, p. 1935-1943, 2005.

BOGDANOVA, E.; BASS, I.; MINAKHIN, L.; PETROVA, M.; MINDLIN, S.; VOLODIN, A.; KALYAEVA, E.; TIEDJE, J.; HOBMAN, J.; BROWN, N. Horizontal spread of mer operons among Gram-positive bacteria in natural environments. Microbiology, v. 144, n. 3, p. 609-620, 1998.

BORRISS, M.; HELMKE, E.; HANSCHKE, R.; SCHWEDER, T. Isolation and characterization of marine psychrophilic phage-host systems from Arctic sea ice. Extremophiles, v. 7, n. 5, p. 377384, 2003.

BOWMAN, J. P. The genus Psychrobacter. In: DWORKIN, M.;FALKOW, S., et al (Ed.). The Prokaryotes. New York: Springer, 2006. cap. 35, p.920-930. ISBN 038725496X.

BOYNTON, W. V.; FELDMAN, W. C.; SQUYRES, S. W.; PRETTYMAN, T. H.; BRUCKNER, J.; EVANS, L. G.; REEDY, R. C.; STARR, R.; ARNOLD, J. R.; DRAKE, D. M.; ENGLERT, P. A. J.; METZGER, A. E.; MITROFANOV, I.; TROMBKA, J. I.; D'USTON, C.; WANKE, H.; GASNAULT, O.; HAMARA, D. K.; JANES, D. M.; MARCIALIS, R. L.; MAURICE, S.; MIKHEEVA, I.; TAYLOR, G. J.; TOKAR, R.; SHINOHARA, C. Distribution of hydrogen in the near surface of Mars: Evidence for subsurface ice deposits. Science, v. 297, n. 5578, p. 81-85, 2002.

BRAMBILLA, E.; HIPPE, H.; HAGELSTEIN, A.; TINDALL, B. J.; STACKEBRANDT, E. 16S rDNA diversity of cultured and uncultured prokaryotes of a mat sample from Lake Fryxell, McMurdo Dry Valleys, Antarctica. Extremophiles, v. 5, n. 1, p. 23-33, 2001.

BRAY, J. R.; CURTIS, J. T. An ordination of the upland forest communities of southern Wisconsin. Ecological Monographs, v. 27, n. 4, p. 325-349, 1957.

BRITTON, G. Structure and properties of carotenoids in relation to function. Faseb Journal, v. 9, n. 15, p. 1551-1558, 1995.

BUDDE, I.; STEIL, L.; SCHARF, C.; VOLKER, U.; BREMER, E. Adaptation of Bacillus subtilis to growth at low temperature: a combined transcriptomic and proteomic appraisal. Microbiology, v. 152, n. Pt 3, p. 831-853, 2006.

BUTTLE, J.; FRASER, K. Hydrochemical fluxes in a High Arctic wetland basin during spring snowmelt. Arctic and Alpine Research, p. 153-164, 1992.

CAPORASO, J. G.; KUCZYNSKI, J.; STOMBAUGH, J.; BITTINGER, K.; BUSHMAN, F. D.; COSTELLO, E. K.; FIERER, N.; PENA, A. G.; GOODRICH, J. K.; GORDON, J. I. QIIME allows analysis of highthroughput community sequencing data. Nature methods, v. 7, n. 5, p. 335-336, 2010. 
CARNEIRO, A. R.; RAMOS, R. T. J.; DALL'AGNOL, H.; PINTO, A. C.; DE CASTRO SOARES, S.; SANTOS, A. R.; GUIMARÃES, L. C.; ALMEIDA, S. S.; BARAÚNA, R. A.; DAS GRAÇAS, D. A.; FRANCO, L. C.; ALI, A.; HASSAN, S. S.; NUNES, C. I. P.; BARBOSA, M. S.; FIAUX, K. K.; ABURJAILE, F. F.; BARBOSA, E. G. V.; BAKHTIAR, S. M.; VILELA, D.; NÓBREGA, F.; DOS SANTOS, A. L.; CAREPO, M. S. P.; AZEVEDO, V.; SCHNEIDER, M. P. C.; PELLIZARI, V. H.; SILVA, A. Genome Sequence of Exiguobacterium antarcticum B7, Isolated from a Biofilm in Ginger Lake, King George Island, Antarctica. Journal of Bacteriology, v. 194, n. 23, p. 6689-6690, 2012.

CASELLI, A. T.; DOS SANTOS AFONSO, M.; AGUSTO, M. R. Gases fumarólicos de la Isla Decepción (Shetland del Sur, Antártida): variaciones químicas y depósitos vinculados a la crisis sísmica de 1999. Revista de la Asociación Geológica Argentina, v. 59, n. 2, p. 291-302, 2004.

CAVASSO FILHO, R. L.; HOMEN, M. G.; FONSECA, P. T.; NAVES DE BRITO, A. A synchrotron beamline for delivering high purity vacuum ultraviolet photons. Review of Scientific Instruments, v. 78, n. 11, p. 115104, 2007.

CHAKRABORTEE, S.; BOSCHETTI, C.; WALTON, L. J.; SARKAR, S.; RUBINSZTEIN, D. C.; TUNNACLIFFE, A. Hydrophilic protein associated with desiccation tolerance exhibits broad protein stabilization function. Proceedings of the National Academy of Sciences, v. 104, n. 46, p. 18073-18078, 2007.

CHAKRAVORTY, S.; HELB, D.; BURDAY, M.; CONNELL, N.; ALLAND, D. A detailed analysis of 16S ribosomal RNA gene segments for the diagnosis of pathogenic bacteria. Journal of Microbiological Methods, v. 69, n. 2, p. 330-339, 2007.

CHAO, A. NONPARAMETRIC-ESTIMATION OF THE NUMBER OF CLASSES IN A POPULATION. Scandinavian Journal of Statistics, v. 11, n. 4, p. 265-270, 1984.

CHAO, A.; LEE, S. M. ESTIMATING THE NUMBER OF CLASSES VIA SAMPLE COVERAGE. Journal of the American Statistical Association, v. 87, n. 417, p. 210-217, 1992.

CHATURVEDI, P.; PRABAHAR, V.; MANORAMA, R.; PINDI, P. K.; BHADRA, B.; BEGUM, Z.; SHIVAJI, S. Exiguobacterium soli sp nov., a psychrophilic bacterium from the McMurdo Dry Valleys, Antarctica. International Journal of Systematic and Evolutionary Microbiology, v. 58, p. 2447-2453, 2008.

CHATURVEDI, P.; SHIVAJI, S. Exiguobacterium indicum sp. nov., a psychrophilic bacterium from the Hamta glacier of the Himalayan mountain ranges of India. International Journal Systematic Evolionary Microbiology, v. 56, n. Pt 12, p. 2765-2770, 2006.

CHEVRIER, V. F.; HANLEY, J.; ALTHEIDE, T. S. Stability of perchlorate hydrates and their liquid solutions at the Phoenix landing site, Mars. Geophysical Research Letters, v. 36, p. 6, 2009.

$\mathrm{CHO}$, I.; BLASER, M. J. Applications of next-generation sequencing. The human microbiome: at the interface of health and disease. Nature Reviews Genetics, v. 13, n. 4, p. 260-270, 2012. 
CLARKE, K. R.; SOMERFIELD, P. J.; CHAPMAN, M. G. On resemblance measures for ecological studies, including taxonomic dissimilarities and a zero-adjusted Bray-Curtis coefficient for denuded assemblages. Journal of Experimental Marine Biology and Ecology, v. 330, n. 1, p. 55-80, 2006.

CLEGG, J. S. Cryptobiosis - A peculiar state of biological organization. Comparative Biochemistry and Physiology Part B: Biochemistry and Molecular Biology, v. 128, n. 4, p. 613624, 2001.

COLE, J. R.; CHAI, B.; FARRIS, R. J.; WANG, Q.; KULAM-SYED-MOHIDEEN, A.; MCGARRELL, D. M.; BANDELA, A.; CARDENAS, E.; GARRITY, G. M.; TIEDJE, J. M. The ribosomal database project (RDP-II): introducing myRDP space and quality controlled public data. Nucleic Acids Research, v. 35, p. D169-D172, 2007.

CONSORTIUM, H. M. P. Structure, function and diversity of the healthy human microbiome. Nature, v. 486, n. 7402, p. 207-214, 2012.

CONSORTIUM, I. H. G. S. Finishing the euchromatic sequence of the human genome. Nature, v. 431, n. 7011, p. 931-945, 2004.

CRAPART, S.; FARDEAU, M. L.; CAYOL, J. L.; THOMAS, P.; SERY, C.; OLLIVIER, B.; COMBETBLANC, Y. Exiguobacterium profundum sp nov., a moderately thermophilic, lactic acidproducing bacterium isolated from a deep-sea hydrothermal vent. International Journal of Systematic and Evolutionary Microbiology, v. 57, p. 287-292, 2007.

CSERMELY, P.; SCHNAIDER, T.; SOTI, C.; PROHASZKA, Z.; NARDAI, G. The 90-kDa molecular chaperone family: structure, function, and clinical applications. A comprehensive review. Pharmacology \& Therapeutics, v. 79, n. 2, p. 129-168, 1998.

DALL'AGNOL, H. P. M. B.; BARAUNA, R. A.; DE SA, P. H. C. G.; RAMOS, R. T. J.; NOBREGA, F.; NUNES, C. I. P.; DAS GRACAS, D. A.; CARNEIRO, A. R.; SANTOS, D. M.; PIMENTA, A. M. C.; CAREPO, M. S. P.; AZEVEDO, V.; PELLIZARI, V. H.; SCHNEIDER, M. P. C.; SILVA, A. Omics profiles used to evaluate the gene expression of Exiguobacterium antarcticum B7 during cold adaptation. Bmc Genomics, v. 15, 2014.

DARTNELL, L. Biological constraints on habitability. Astronomy \& Geophysics, v. 52, n. 1, p. 25-28, 2011.

DAVILA, A. F.; DUPORT, L. G.; MELCHIORRI, R.; JANCHEN, J.; VALEA, S.; DE LOS RIOS, A.; FAIREN, A. G.; MOHLMANN, D.; MCKAY, C. P.; ASCASO, C.; WIERZCHOS, J. Hygroscopic Salts and the Potential for Life on Mars. Astrobiology, v. 10, n. 6, p. 617-628, 2010.

DE OLIVEIRA, V. E.; CASTRO, H. V.; EDWARDS, H. G. M.; DE OLIVEIRA, L. F. C. Carotenes and carotenoids in natural biological samples: a Raman spectroscopic analysis. Journal of Raman Spectroscopy, v. 41, n. 6, p. 642-650, 2010. 
DEHEYN, D. D.; GENDREAU, P.; BALDWIN, R. J.; LATZ, M. I. Evidence for enhanced bioavailability of trace elements in the marine ecosystem of Deception Island, a volcano in Antarctica. Marine Environmental Research, v. 60, n. 1, p. 1-33, 2005.

DES MARAIS, D. J.; NUTH, J. A.; ALLAMANDOLA, L. J.; BOSS, A. P.; FARMER, J. D.; HOEHLER, T. M.; JAKOSKY, B. M.; MEADOWS, V. S.; POHORILLE, A.; RUNNEGAR, B.; SPORMANN, A. M. The NASA Astrobiology Roadmap. Astrobiology, v. 8, n. 4, p. 715-730, 2008.

DESANTIS, T. Z.; HUGENHOLTZ, P.; LARSEN, N.; ROJAS, M.; BRODIE, E. L.; KELLER, K.; HUBER, T.; DALEVI, D.; HU, P.; ANDERSEN, G. L. Greengenes, a chimera-checked 16S rRNA gene database and workbench compatible with ARB. Applied and Environmental Microbiology, v. 72, n. 7, p. 5069-5072, 2006.

DOJKA, M. A.; HARRIS, J. K.; PACE, N. R. Expanding the known diversity and environmental distribution of an uncultured phylogenetic division of bacteria. Applied and Environmental Microbiology, v. 66, n. 4, p. 1617-1621, 2000.

DOOLITTLE, W. F.; ZHAXYBAYEVA, O. On the origin of prokaryotic species. Genome Research, v. 19, n. 5, p. 744-756, 2009.

DUARTE, R. T. D. Micro-organismos em ambientes criogênicos: gelo glacial, solos expostos por recuo de geleiras, e permafrost polares. 2010. (Tese de Doutorado). Biotecnologia, Universidade de São Paulo, São Paulo.

DUARTE, R. T. D.; NÓBREGA, F.; NAKAYAMA, C. R.; PELLIZARI, V. H. Brazilian research on extremophiles in the context of astrobiology. International Journal of Astrobiology, v. 11, n. 04, p. 325-333, 2012.

EDGAR, R. C.; HAAS, B. J.; CLEMENTE, J. C.; QUINCE, C.; KNIGHT, R. UCHIME improves sensitivity and speed of chimera detection. Bioinformatics, v. 27, n. 16, p. 2194-2200, 2011.

EMBLEY, T.; STACKEBRANDT, E. The molecular phylogency and systematics of the actinomycetes. Annual Reviews in Microbiology, v. 48, n. 1, p. 257-289, 1994.

EVERDINGEN, R. O. V. Geocryological terminology. Canadian Journal of Earth Sciences, v. 13, n. 6, p. 862-867, 1976.

FEDURCO, M.; ROMIEU, A.; WILLIAMS, S.; LAWRENCE, I.; TURCATTI, G. BTA, a novel reagent for DNA attachment on glass and efficient generation of solid-phase amplified DNA colonies. Nucleic Acids Research, v. 34, n. 3, 2006.

FISCHER, E.; MARTINEZ, G. M.; ELLIOTT, H. M.; RENNO, N. O. Experimental evidence for the formation of liquid saline water on Mars. Geophysical Research Letters, v. 41, n. 13, p. 44564462, 2014.

FORTIER, D.; ALLARD, M. Frost-cracking conditions, Bylot Island, eastern Canadian arctic archipelago. Permafrost and Periglacial Processes, v. 16, n. 2, p. 145-162, 2005. 
FRANCA, M. B.; PANEK, A. D.; ELEUTHERIO, E. C. Oxidative stress and its effects during dehydration. Comparative Biochemistry and Physiology Part A: Molecular \& Integrative Physiology, v. 146, n. 4, p. 621-631, 2007.

FRANCO, D. A. C. Estudo da diversidade molecular de bactérias e arqueias e enriquecimento de comunidades metanogênicas em sedimentos marinhos antárticos. 2014. (Mestrado). Biotecnologia, Universidade de São Paulo, São Paulo, 2014.

FREDRICKSON, J. K.; LI, S.-M. W.; GAIDAMAKOVA, E. K.; MATROSOVA, V. Y.; ZHAI, M.; SULLOWAY, H. M.; SCHOLTEN, J. C.; BROWN, M. G.; BALKWILL, D. L.; DALY, M. J. Protein oxidation: key to bacterial desiccation resistance? ISME Journal, v. 2, n. 4, p. 393-403, 2008.

FRENCH, H.; THORN, C. E. The changing nature of periglacial geomorphology. Géomorphologie: Relief, Processus, Environnement, n. 3/2006, 2006.

FRENCH, H. M. The periglacial environment. Chichester, UK: John Wiley \& Sons, 2013. ISBN $111868494 \mathrm{X}$.

FRUHLING, A.; SCHUMANN, P.; HIPPE, H.; STRAUBLER, B.; STACKEBRANDT, E. Exiguobacterium undae sp. nov. and Exiguobacterium antarcticum sp. nov. International Journal of Systematic and Evolutionary Microbiology, v. 52, p. 1171-1176, 2002.

FRY, J. C.; PARKES, R. J.; CRAGG, B. A.; WEIGHTMAN, A. J.; WEBSTER, G. Prokaryotic biodiversity and activity in the deep subseafloor biosphere. FEMS Microbiology Ecology, v. 66, n. 2, p. 181196, 2008.

GARCIA, A. H. Anhydrobiosis in bacteria: From physiology to applications. Journal of Biosciences, v. 36, n. 5, p. 939-950, 2011.

GIANDOMENICO, A. R.; CERNIGLIA, G. E.; BIAGLOW, J. E.; STEVENS, C. W.; KOCH, C. J. The Importance of Sodium Pyruvate in Assessing Damage Produced by Hydrogen Peroxide. Free Radical Biology and Medicine, v. 23, n. 3, p. 426-434, 1997.

GIANESE, G.; BOSSA, F.; PASCARELLA, S. Comparative structural analysis of psychrophilic and meso- and thermophilic enzymes. Proteins-Structure Function and Bioinformatics, v. 47, n. 2, p. 236-249, 2002.

GILICHINSKY, D. Permafrost. Encyclopedia of environmental microbiology, 2002.

GILICHINSKY, D. A.; WILSON, G. S.; FRIEDMANN, E. I.; MCKAY, C. P.; SLETTEN, R. S.; RIVKINA, E. M.; VISHNIVETSKAYA, T. A.; EROKHINA, L. G.; IVANUSHKINA, N. E.; KOCHKINA, G. A.; SHCHERBAKOVA, V. A.; SOINA, V. S.; SPIRINA, E. V.; VOROBYOVA, E. A.; FYODOROV-DAVYDOV, D. G.; HALLET, B.; OZERSKAYA, S. M.; SOROKOVIKOV, V. A.; LAURINAVICHYUS, K. S.; SHATILOVICH, A. V.; CHANTON, J. P.; OSTROUMOV, V. E.; TIEDJE, J. M. Microbial populations in antarctic permafrost: biodiversity, state, age, and implication for astrobiology. Astrobiology, v. 7, n. 2, p. 275-311, 2007. 
GOODFELLOW, M.; WILLIAMS, S. Ecology of actinomycetes. Annual Reviews in Microbiology, v. 37, n. 1, p. 189-216, 1983.

GUPTA, R. S. The phylogeny of proteobacteria: relationships to other eubacterial phyla and eukaryotes. Fems Microbiology Reviews, v. 24, n. 4, p. 367-402, 2000.

GUPTA, R. S.; GRIFFITHS, E. Critical issues in bacterial phylogeny. Theoretical Population Biology, v. 61, n. 4, p. 423-434, 2002.

HAND, K. P.; CARLSON, R. W.; CHYBA, C. F. Energy, chemical disequilibrium, and geological constraints on Europa. Astrobiology, v. 7, n. 6, p. 1006-1022, 2007.

HANSEN, A. A.; JENSEN, L. L.; KRISTOFFERSEN, T.; MIKKELSEN, K.; MERRISON, J.; FINSTER, K. W.; LOMSTEIN, B. A. Effects of long-term simulated martian conditions on a freeze-dried and homogenized bacterial permafrost community. Astrobiology, v. 9, n. 2, p. 229-240, 2009.

HARRISON, J. P.; GHEERAERT, N.; TSIGELNITSKIY, D.; COCKELL, C. S. The limits for life under multiple extremes. Trends in Microbiology, v. 21, n. 4, p. 204-212, 2013.

HAYDEN, E. C. Is the \$1,000 genome for real. Nature News, 2014.

HECK JR, K. L.; VAN BELLE, G.; SIMBERLOFF, D. Explicit calculation of the rarefaction diversity measurement and the determination of sufficient sample size. Ecology, p. 1459-1461, 1975.

HUGENHOLTZ, P.; GOEBEL, B. M.; PACE, N. R. Impact of culture-independent studies on the emerging phylogenetic view of bacterial diversity. Journal of Bacteriology, v. 180, n. 18, p. 4765-4774, 1998.

HUGENHOLTZ, P.; STACKEBRANDT, E. Reclassification of Sphaerobacter thermophilus from the subclass Sphaerobacteridae in the phylum Actinobacteria to the class Thermomicrobia (emended description) in the phylum Chloroflexi (emended description). International Journal of Systematic and Evolutionary Microbiology, v. 54, n. 6, p. 2049-2051, 2004.

HUGHES, J. B.; HELLMANN, J. J.; RICKETTS, T. H.; BOHANNAN, B. J. M. Counting the uncountable: statistical approaches to estimating microbial diversity. Applied and Environmental Microbiology, v. 67, n. 10, p. 4399-4406, 2001.

IESS, L.; STEVENSON, D. J.; PARISI, M.; HEMINGWAY, D.; JACOBSON, R. A.; LUNINE, J. I.; NIMMO, F.; ARMSTRONG, J. W.; ASMAR, S. W.; DUCCI, M.; TORTORA, P. The gravity field and interior structure of Enceladus. Science, v. 344, n. 6179, p. 78-80, 2014.

JANSSEN, P. H. Identifying the dominant soil bacterial taxa in libraries of 16S rRNA and 165 rRNA genes. Applied and Environmental Microbiology, v. 72, n. 3, p. 1719-1728, 2006.

JANSSON, J. K.; TAS, N. The microbial ecology of permafrost. Nature Reviews Microbiology, v. 12, n. 6, p. 414-425, 2014. 
JOHNSON, S. S.; HEBSGAARD, M. B.; CHRISTENSEN, T. R.; MASTEPANOV, M.; NIELSEN, R.; MUNCH, K.; BRAND, T.; THOMAS, M.; GILBERT, P.; ZUBER, M. T.; BUNCE, M.; RONN, R.; GILICHINSKY, D.; FROESE, D.; WILLERSLEV, E. Ancient bacteria show evidence of DNA repair. Proceedings of the National Academy of Sciences of the United States of America, v. 104, n. 36, p. 14401-14405, 2007.

JORGENSON, M. T.; SHUR, Y. L.; PULLMAN, E. R. Abrupt increase in permafrost degradation in Arctic Alaska. Geophysical Research Letters, v. 33, n. 2, 2006.

KERESZTURI, A.; RIVERA-VALENTIN, E. G. Locations of thin liquid water layers on present-day Mars. Icarus, v. 221, n. 1, p. 289-295, 2012.

KERR, R. A. Liquid water found on Mars, but it's still a hard road for life. Science, v. 330, n. 6004, p. 571-571, 2010.

KISHIMOTO, N.; KOSAKO, Y.; TANO, T. Acidobacterium capsulatum gen. nov., sp. nov.: an acidophilic chemoorganotrophic bacterium containing menaquinone from acidic mineral environment. Current Microbiology, v. 22, n. 1, p. 1-7, 1991.

KLINDWORTH, A.; PRUESSE, E.; SCHWEER, T.; PEPLIES, J.; QUAST, C.; HORN, M.; GLOCKNER, F. O. Evaluation of general $16 \mathrm{~S}$ ribosomal RNA gene PCR primers for classical and nextgeneration sequencing-based diversity studies. Nucleic Acids Research, v. 41, n. 1, 2013.

KOZICH, J. J.; WESTCOTT, S. L.; BAXTER, N. T.; HIGHLANDER, S. K.; SCHLOSS, P. D. Development of a Dual-index sequencing strategy and curation pipeline for analyzing amplicon sequence data on the MiSeq Illumina sequencing platform. Applied and Environmental Microbiology, v. 79, n. 17, p. 5112-5120, 2013.

KRESLAVSKY, M. A.; HEAD, J. W. Kilometer-scale roughness of Mars: Results from MOLA data analysis. Journal of Geophysical Research: Planets (1991-2012), v. 105, n. E11, p. 2669526711, 2000.

KURIHARA, K.; TAMURA, M.; SHOHDA, K.-I.; TOYOTA, T.; SUZUKI, K.; SUGAWARA, T. Selfreproduction of supramolecular giant vesicles combined with the amplification of encapsulated DNA. Nature Chemistry, v. 3, n. 10, p. 775-781, 2011.

KUSKE, C. R.; BARNS, S. M.; BUSCH, J. D. Diverse uncultivated bacterial groups from soils of the arid southwestern United States that are present in many geographic regions. Applied and Environmental Microbiology, v. 63, n. 9, p. 3614-3621, 1997.

LACHENBRUCH, A. H. Mechanics of Thermal Contraction Cracks and Ice-Wedge Polygons in Permafrost. Geological Society of America Special Papers, v. 70, p. 1-66, 1962.

LAWRENCE, M. J. F.; HENDY, C. H. Water column and sediment characteristics of Lake Fryxell, Taylor Valley, Antarctica. New Zealand Journal of Geology and Geophysics, v. 28, n. 3, p. 543$552,1985$. 
LELIVELT, M. J.; KAWULA, T. H. Hsc66, an Hsp70 homolog in Escherichia coli, is induced by cold shock but not by heat shock. Journal of Bacteriology, v. 177, n. 17, p. 4900-4907, 1995.

LEVY, J.; HEAD, J.; MARCHANT, D. Thermal contraction crack polygons on Mars: Classification, distribution, and climate implications from HiRISE observations. Journal of Geophysical Research-Planets, v. 114, p. 19, 2009.

LEVY, J. S.; MARCHANTB, D. R.; HEAD, J. W. Thermal contraction crack polygons on Mars: A synthesis from HiRISE, Phoenix, and terrestrial analog studies. Icarus, v. 206, n. 1, p. 229-252, 2010.

LIMA, I. G. P. Investigação das condições de sobrevivência de microrganismos extremófilos em ambientes extraterrestres simulados. 2010. (Tese de Doutorado). Instituto de Biofísica Carlos Chagas Filho, Universidade Federal do Rio de Janeiro, Rio de Janeiro, 2010.

LOCK, G. S. H. The growth and decay of ice. New York: Cambridge University Press, 1990. ISBN 0521331331.

LOGARES, R.; HAVERKAMP, T. H. A.; KUMAR, S.; LANZEN, A.; NEDERBRAGT, A. J.; QUINCE, C.; KAUSERUD, $H$. Environmental microbiology through the lens of high-throughput DNA sequencing: Synopsis of current platforms and bioinformatics approaches. Journal of Microbiological Methods, v. 91, n. 1, p. 106-113, 2012.

LUDWIG, W.; STRUNK, O.; WESTRAM, R.; RICHTER, L.; MEIER, H.; YADHUKUMAR; BUCHNER, A.; LAI, T.; STEPPI, S.; JOBB, G.; FÖRSTER, W.; BRETTSKE, I.; GERBER, S.; GINHART, A. W.; GROSS, O.; GRUMANN, S.; HERMANN, S.; JOST, R.; KÖNIG, A.; LISS, T.; LÜßMANN, R.; MAY, M.; NONHOFF, B.; REICHEL, B.; STREHLOW, R.; STAMATAKIS, A.; STUCKMANN, N.; VILBIG, A.; LENKE, M.; LUDWIG, T.; BODE, A.; SCHLEIFER, K. H. ARB: a software environment for sequence data. Nucleic Acids Research, v. 32, n. 4, p. 1363-1371, 2004.

LUNDBERG, D. S.; YOURSTONE, S.; MIECZKOWSKI, P.; JONES, C. D.; DANGL, J. L. Practical innovations for high-throughput amplicon sequencing. Nature Methods, v. 10, n. 10, p. 999$+, 2013$.

MACKAY, J. Deformation of ice-wedge polygons, Garry Island, Northwest Territories. Current Research, Part A. Geological Survey of Canada, Paper, p. 287-291, 1980.

MACKAY, J. R. The world of underground ice. Annals of the Association of American Geographers, v. 62, n. 1, p. 1-22, 1972.

MACKELPRANG, R.; WALDROP, M. P.; DEANGELIS, K. M.; DAVID, M. M.; CHAVARRIA, K. L.; BLAZEWICZ, S. J.; RUBIN, E. M.; JANSSON, J. K. Metagenomic analysis of a permafrost microbial community reveals a rapid response to thaw. Nature, v. 480, n. 7377, p. 368-371, 2011. 
MALIN, M. C.; EDGETT, K. S. Mars Global Surveyor Mars Orbiter Camera: Interplanetary cruise through primary mission. Journal of Geophysical Research-Planets, v. 106, n. E10, p. 2342923570, 2001.

MANGOLD, N. High latitude patterned grounds on Mars: Classification, distribution and climatic control. Icarus, v. 174, n. 2, p. 336-359, 2005.

MARGESIN, R. Permafrost soils. Heidelberg, Germany: Springer Science \& Business Media, 2008. ISBN 3540693718.

MARGESIN, R.; MITEVA, V. Diversity and ecology of psychrophilic microorganisms. Research in Microbiology, v. 162, n. 3, p. 346-361, 2011.

MARTIN, B.; HUMBERT, O.; CAMARA, M.; GUENZI, E.; WALKER, J.; MITCHELL, T.; ANDREW, P.; PRUDHOMME, M.; ALLOING, G.; HAKENBECK, R.; ET AL. A highly conserved repeated DNA element located in the chromosome of Streptococcus pneumoniae. Nucleic Acids Res, v. 20, n. 13, p. 3479-3483, 1992.

MARTIN, W.; RUSSELL, M. J. On the origins of cells: a hypothesis for the evolutionary transitions from abiotic geochemistry to chemoautotrophic prokaryotes, and from prokaryotes to nucleated cells. Philosophical Transactions of the Royal Society B: Biological Sciences, v. 358, n. 1429, p. 59-85, 2003.

MAYILRAJ, S.; PRASAD, G. S.; SURESH, K.; SAINI, H. S.; SHIVAJI, S.; CHAKRABARTI, T. Planococcus stackebrandtii sp. nov., isolated from a cold desert of the Himalayas, India. International Journal of Systematic and Evolutionary Microbiology, v. 55, p. 91-94, 2005.

MCEWEN, A. S.; DUNDAS, C. M.; MATTSON, S. S.; TOIGO, A. D.; OJHA, L.; WRAY, J. J.; CHOJNACKI, M.; BYRNE, S.; MURCHIE, S. L.; THOMAS, N. Recurring slope lineae in equatorial regions of Mars. Nature Geoscience, v. 7, n. 1, p. 53-58, 2014.

MCEWEN, A. S.; ELIASON, E. M.; BERGSTROM, J. W.; BRIDGES, N. T.; HANSEN, C. J.; DELAMERE, W. A.; GRANT, J. A.; GULICK, V. C.; HERKENHOFF, K. E.; KESZTHELYI, L.; KIRK, R. L.; MELLON, M. T.; SQUYRES, S. W.; THOMAS, N.; WEITZ, C. M. Mars Reconnaissance Orbiter's High Resolution Imaging Science Experiment (HiRISE). Journal of Geophysical Research-Planets, v. 112, n. E5, p. 40, 2007.

MEESSEN, J.; WUTHENOW, P.; SCHILLE, P.; RABBOW, E.; DE VERA, J. P. P.; OTT, S. Resistance of the lichen Buellia frigida to simulated space conditions during the preflight tests for BIOMEX-Viability assay and morphological stability. Astrobiology, v. 15, n. 8, p. 601-615, 2015.

MELLON, M. T.; ARVIDSON, R. E.; MARLOW, J. J.; PHILLIPS, R. J.; ASPHAUG, E. Periglacial landforms at the Phoenix landing site and the northern plains of Mars. Journal of Geophysical Research-Planets, v. 113, p. 15, 2008. 
MELLON, M. T.; MALIN, M. C.; ARVIDSON, R. E.; SEARLS, M. L.; SIZEMORE, H. G.; HEET, T. L.; LEMMON, M. T.; KELLER, H. U.; MARSHALL, J. The periglacial landscape at the Phoenix landing site. Journal of Geophysical Research-Planets, v. 114, p. 13, 2009.

MERRICK, T. P.; BRUCE, A. K. Radiation Response of Potassium Efflux in Micrococcus Radiodurans and Sarcina Lutea. Radiation Research, v. 24, p. 612-618, 1965.

METZKER, M. L. Sequencing technologies - the next generation. Nature Reviews Genetics, v. 11, n. 1, p. 31-46, 2010.

MONTES, M. J.; MERCADE, E.; BOZAL, N.; GUINEA, J. Paenibacillus antarcticus sp. nov., a novel psychrotolerant organism from the Antarctic environment. International Journal of Systematic and Evolutionary Microbiology, v. 54, n. Pt 5, p. 1521-1526, 2004.

MOROZOVA, D.; MOHLMANN, D.; WAGNER, D. Survival of methanogenic archaea from Siberian permafrost under simulated Martian thermal conditions. Origins of Life and Evolution of Biospheres, v. 37, n. 2, p. 189-200, 2007.

MUSTARD, J. F.; COOPER, C. D.; RIFKIN, M. K. Evidence for recent climate change on Mars from the identification of youthful near-surface ground ice. Nature, v. 412, n. 6845, p. 411-414, 2001.

MYKYTCZUK, N. C. S.; FOOTE, S. J.; OMELON, C. R.; SOUTHAM, G.; GREER, C. W.; WHYTE, L. G. Bacterial growth at-15 degrees $C$; molecular insights from the permafrost bacterium Planococcus halocryophilus Or1. ISME Journal, v. 7, n. 6, p. 1211-1226, 2013.

MYKYTCZUK, N. C. S.; WILHELM, R. C.; WHYTE, L. G. Planococcus halocryophilus sp. nov., an extreme sub-zero species from high Arctic permafrost. International Journal of Systematic and Evolutionary Microbiology, v. 62, n. Pt 8, p. 1937-1944, 2012.

NARVAEZ-REINALDO, J. J.; BARBA, I.; GONZALEZ-LOPEZ, J.; TUNNACLIFFE, A.; MANZANERA, M. Rapid method for isolation of desiccation-tolerant strains and xeroprotectants. Applied and Environmental Microbiology, v. 76, n. 15, p. 5254-5262, 2010.

NELSON, M. C.; MORRISON, H. G.; BENJAMINO, J.; GRIM, S. L.; GRAF, J. Analysis, optimization and verification of Illumina-generated $16 \mathrm{~S}$ rRNA gene amplicon surveys. Plos One, v. 9, n. 4, p. 14, 2014.

NIEDERBERGER, T. D.; PERREAULT, N. N.; TILLE, S.; LOLLAR, B. S.; LACRAMPE-COULOUME, G.; ANDERSEN, D.; GREER, C. W.; POLLARD, W.; WHYTE, L. G. Microbial characterization of a subzero, hypersaline methane seep in the Canadian High Arctic. Isme Journal, v. 4, n. 10, p. 1326-1339, 2010.

OFARRELL, P. H. High-resolution 2-dimensional electrophoresis of proteins. Journal of Biological Chemistry, v. 250, n. 10, p. 4007-4021, 1975. 
OJHA, L.; WILHELM, M. B.; MURCHIE, S. L.; MCEWEN, A. S.; WRAY, J. J.; HANLEY, J.; MASSÉ, M.; CHOJNACKI, M. Spectral evidence for hydrated salts in recurring slope lineae on Mars. Nature Geoscience, 2015.

OLSSON-FRANCIS, K.; COCKELL, C. S. Experimental methods for studying microbial survival in extraterrestrial environments. Journal of Microbiological Methods, v. 80, n. 1, p. 1-13, 2010.

PARKINSON, C. L. Earth's Cryosphere: Current State and Recent Changes*. Annual Review of Environment and Resources, v. 31, n. 1, p. 33-60, 2006.

PARKS, D. H.; BEIKO, R. G. Measures of phylogenetic differentiation provide robust and complementary insights into microbial communities. ISME Journal, v. 7, n. 1, p. 173-183, 2013.

PAULINO-LIMA, I. G.; JANOT-PACHECO, E.; GALANTE, D.; COCKELL, C.; OLSSON-FRANCIS, K.; BRUCATO, J. R.; BARATTA, G. A.; STRAZZULLA, G.; MERRIGAN, T.; MCCULLOUGH, R.; MASON, N.; LAGE, C. Survival of Deinococcus radiodurans against laboratory-simulated solar wind charged particles. Astrobiology, v. 11, n. 9, p. 875-882, 2011.

PECHMANN, J. C. The origin of polygonal troughs on the northern plains of Mars. Icarus, v. 42, n. 2, p. 185-210, 1980.

PHADTARE, S. Unwinding activity of cold shock proteins and RNA metabolism. RNA Biology, v. 8, n. 3, p. 394-397, 2011.

PHADTARE, S.; INOUYE, M.; SEVERINOV, K. The nucleic acid melting activity of Escherichia coli CspE is critical for transcription antitermination and cold acclimation of cells. Journal of Biological Chemistry, v. 277, n. 9, p. 7239-7245, 2002.

PLUG, L. J.; WERNER, B. Nonlinear dynamics of ice-wedge networks and resulting sensitivity to severe cooling events. Nature, v. 417, n. 6892, p. 929-933, 2002.

POLLARD, W.; HALTIGIN, T.; WHYTE, L.; NIEDERBERGER, T.; ANDERSEN, D.; OMELON, C.; NADEAU, J.; ECCLESTONE, M.; LEBEUF, M. Overview of analogue science activities at the McGill Arctic Research Station, Axel Heiberg Island, Canadian High Arctic. Planetary and Space Science, v. 57, n. 5-6, p. 646-659, 2009.

PRISCU, J. C.; CHRISTNER, B. C. Earth's icy biosphere. Microbial Diversity and Bioprospecting, p. 130-145, 2004.

PRUESSE, E.; PEPLIES, J.; GLÖCKNER, F. O. SINA: Accurate high-throughput multiple sequence alignment of ribosomal RNA genes. Bioinformatics, v. 28, n. 14, p. 1823-1829, 2012.

PRUESSE, E.; QUAST, C.; KNITTEL, K.; FUCHS, B. M.; LUDWIG, W.; PEPLIES, J.; GLÖCKNER, F. O. SILVA: a comprehensive online resource for quality checked and aligned ribosomal RNA sequence data compatible with ARB. Nucleic Acids Research, v. 35, n. 21, p. 7188-7196, 2007. 
PULSCHEN, A. A.; RODRIGUES, F.; DUARTE, R. T. D.; ARAUJO, G. G.; SANTIAGO, I. F.; PAULINOLIMA, I. G.; ROSA, C. A.; KATO, M. J.; PELLIZARI, V. H.; GALANTE, D. UV-resistant yeasts isolated from a high-altitude volcanic area on the Atacama Desert as eukaryotic models for astrobiology. MicrobiologyOpen, v. 4, n. 4, p. 574-588, 2015.

QIU, Y. H.; KATHARIOU, S.; LUBMAN, D. M. Proteomic analysis of cold adaptation in a Siberian permafrost bacterium - Exiguobacterium sibiricum 255-15 by two-dimensional liquid separation coupled with mass spectrometry. Proteomics, v. 6, n. 19, p. 5221-5233, 2006.

QUAIL, M. A.; OTTO, T. D.; GU, Y.; HARRIS, S. R.; SKELLY, T. F.; MCQUILLAN, J. A.; SWERDLOW, H. P.; OYOLA, S. O. Optimal enzymes for amplifying sequencing libraries. Nature Methods, v. 9, n. 1, p. 10-11, 2012.

QUAST, C.; PRUESSE, E.; YILMAZ, P.; GERKEN, J.; SCHWEER, T.; YARZA, P.; PEPLIES, J.; GLÖCKNER, F. O. The SILVA ribosomal RNA gene database project: improved data processing and web-based tools. Nucleic Acids Research, v. 41, n. D1, p. D590-D596, 2013.

RABBOW, E.; HORNECK, G.; RETTBERG, P.; SCHOTT, J.-U.; PANITZ, C.; L'AFFLITTO, A.; VON HEISE-ROTENBURG, R.; WILLNECKER, R.; BAGLIONI, P.; HATTON, J.; DETTMANN, J.; DEMETS, R.; REITZ, G. EXPOSE, an astrobiological exposure facility on the International Space Station from proposal to flight. Origins of Life and Evolution of Biospheres, v. 39, n. 6, p. 581-598, 2009.

RAPPÉ, M. S.; GIOVANNONI, S. J. The uncultured microbial majority. Annual Reviews in Microbiology, v. 57, n. 1, p. 369-394, 2003.

RIVKINA, E.; FRIEDMANN, E.; MCKAY, C.; GILICHINSKY, D. Metabolic activity of permafrost bacteria below the freezing point. Applied and Environmental Microbiology, v. 66, n. 8, p. 3230-3233, 2000.

RODRIGUES, D.; GORIS, J.; VISHNIVETSKAYA, T.; GILICHINSKY, D.; THOMASHOW, M.; TIEDJE, J. Characterization of Exiguobacterium isolates from the Siberian permafrost. Description of Exiguobacterium sibiricum sp. nov. Extremophiles, v. 10, n. 4, p. 285-294, 2006.

RODRIGUES, D. F.; IVANOVA, N.; HE, Z. L.; HUEBNER, M.; ZHOU, J. Z.; TIEDJE, J. M. Architecture of thermal adaptation in an Exiguobacterium sibiricum strain isolated from 3 million year old permafrost: A genome and transcriptome approach. BMC Genomics, v. 9, 2008.

RODRIGUES, D. F.; TIEDJE, J. M. Multi-locus real-time PCR for quantitation of bacteria in the environment reveals Exiguobacterium to be prevalent in permafrost. FEMS Microbiology Ecology, v. 59, n. 2, p. 489-499, 2007.

Coping with Our Cold Planet. Applied and Environmental Microbiology, v. 74, n. 6, p. 1677-1686, 2008. 
RODRIGUES, F.; GALANTE, D.; PAULINO-LIMA, I. G.; DUARTE, R. T. D.; FRIACA, A. C. S.; LAGE, C.; JANOT-PACHECO, E.; TEIXEIRA, R.; HORVATH, J. E. Astrobiology in Brazil: early history and perspectives. International Journal of Astrobiology, v. 11, n. 4, p. 189-202, 2012.

ROGOWSKA-WRZESINSKA, A.; LE BIHAN, M. C.; THAYSEN-ANDERSEN, M.; ROEPSTORFF, P. 2D gels still have a niche in proteomics. Journal of Proteomics, v. 88, p. 4-13, 2013.

RONAGHI, M. Pyrosequencing sheds light on DNA sequencing. Genome Research, v. 11, n. 1, p. 3-11, 2001.

RONAGHI, M.; KARAMOHAMED, S.; PETTERSSON, B.; UHLEN, M.; NYREN, P. Real-time DNA sequencing using detection of pyrophosphate release. Analytical Biochemistry, v. 242, n. 1, p. 84-89, 1996.

ROTHSCHILD, L. J.; MANCINELLI, R. L. Life in extreme environments. Nature, v. 409, n. 6823, p. 1092-1101, 2001.

RUSSELL, N. J. COLD ADAPTATION OF MICROORGANISMS. Philosophical Transactions of the Royal Society of London Series B-Biological Sciences, v. 326, n. 1237, p. 595-611, 1990.

ŠABACKÁ, M.; ELSTER, J. Response of cyanobacteria and algae from Antarctic wetland habitats to freezing and desiccation stress. Polar Biology, v. 30, n. 1, p. 31-37, 2006.

SANGER, F.; NICKLEN, S.; COULSON, A. R. DNA sequencing with chain-terminating inhibitors. Proceedings of the National Academy of Sciences, v. 74, n. 12, p. 5463-5467, 1977.

SANTACRUZ-CALVO, L.; GONZÁLEZ-LÓPEZ, J.; MANZANERA, M. Arthrobacter siccitolerans sp. nov., a highly desiccation-tolerant, xeroprotectant-producing strain isolated from dry soil. International Journal of Systematic and Evolutionary Microbiology, v. 63, n. Pt 11, p. 41744180, 2013.

SCHLOSS, J. A. How to get genomes at one ten-thousandth the cost. Nature Biotechnology, v. 26, n. 10, p. 1113-1115, 2008.

SCHLOSS, P. D.; WESTCOTT, S. L.; RYABIN, T.; HALL, J. R.; HARTMANN, M.; HOLLISTER, E. B.; LESNIEWSKI, R. A.; OAKLEY, B. B.; PARKS, D. H.; ROBINSON, C. J. Introducing mothur: opensource, platform-independent, community-supported software for describing and comparing microbial communities. Applied and Environmental Microbiology, v. 75, n. 23, p. 7537-7541, 2009.

SCHUERGER, A. C.; RICHARDS, J. T.; NEWCOMBE, D. A.; VENKATESWARAN, K. Rapid inactivation of seven Bacillus spp. under simulated Mars UV irradiation. Icarus, v. 181, n. 1, p. 52-62, 2006.

SECKBACH, J.; OREN, A. Oxygenic photosynthetic microorganisms in extreme environments. In: SECKBACH, J. (Ed.). Algae and Cyanobacteria in Extreme Environments. Dordrecht, The Netherlands: Springer, 2007. p.3-25. ISBN 1402061110. 
SEIBERT, N. M.; KARGEL, J. S. Small-scale Martian polygonal terrain: Implications for liquid surface water. Geophysical Research Letters, v. 28, n. 5, p. 899-902, 2001.

SEKIGUCHI, Y.; TAKAHASHI, H.; KAMAGATA, Y.; OHASHI, A.; HARADA, H. In situ detection, isolation, and physiological properties of a thin filamentous microorganism abundant in methanogenic granular sludges: a novel isolate affiliated with a clone cluster, the green nonsulfur bacteria, subdivision I. Applied and Environmental Microbiology, v. 67, n. 12, p. 57405749, 2001.

SHANNON, C. E. A MATHEMATICAL THEORY OF COMMUNICATION. Bell System Technical Journal, v. 27, n. 3, p. 379-423, 1948.

SHAWYER, R. Second generation EmDrive propulsion applied to SSTO launcher and interstellar probe. Acta Astronautica, v. 116, p. 166-174, 2015.

SHENDURE, J.; JI, H. L. Next-generation DNA sequencing. Nature Biotechnology, v. 26, n. 10, p. 1135-1145, 2008.

SHIRKEY, B.; MCMASTER, N. J.; SMITH, S. C.; WRIGHT, D. J.; RODRIGUEZ, H.; JARUGA, P.; BIRINCIOGLU, M.; HELM, R. F.; POTTS, M. Genomic DNA of Nostoc commune (Cyanobacteria) becomes covalently modified during long-term (decades) desiccation but is protected from oxidative damage and degradation. Nucleic Acids Research, v. 31, n. 12, p. 2995-3005, 2003.

SHUR, Y.; HINKEL, K. M.; NELSON, F. E. The transient layer: implications for geocryology and climate-change science. Permafrost and Periglacial Processes, v. 16, n. 1, p. 5-17, 2005.

SIMPSON, E. H. Measurement of diversity. Nature, v. 163, n. 4148, p. 688-688, 1949.

SLADE, D.; RADMAN, M. Oxidative stress resistance in Deinococcus radiodurans. Microbiology and Molecular Biology Reviews, v. 75, n. 1, p. 133-191, 2011.

SMITH, D. J.; SCHUERGER, A. C.; DAVIDSON, M. M.; PACALA, S. W.; BAKERMANS, C.; ONSTOTT, T. C. Survivability of Psychrobacter cryohalolentis K5 under simulated martian surface conditions. Astrobiology, v. 9, n. 2, p. 221-228, 2009.

SMITH, J. J.; TOW, L. A.; STAFFORD, W.; CARY, C.; COWAN, D. A. Bacterial diversity in three different Antarctic cold desert mineral soils. Microbial Ecology, v. 51, n. 4, p. 413-421, 2006.

SMITH, N.; HENNESSY, J.; STEAD, D. Repetitive sequence-derived PCR profiling using the BOXA1R primer for rapid identification of the plant pathogen clavibacter michiganensis subspecies sepedonicus. European Journal of Plant Pathology, v. 107, n. 7, p. 739-748, 2001.

SMITH, P. H.; TAMPPARI, L.; ARVIDSON, R. E.; BASS, D.; BLANEY, D.; BOYNTON, W.; CARSWELL, A.; CATLING, D.; CLARK, B.; DUCK, T.; DEJONG, E.; FISHER, D.; GOETZ, W.; GUNNLAUGSSON, P.; HECHT, M.; HIPKIN, V.; HOFFMAN, J.; HVIID, S.; KELLER, H.; KOUNAVES, S.; LANGE, C. F.; LEMMON, M.; MADSEN, M.; MALIN, M.; MARKIEWICZ, W.; MARSHALL, J.; MCKAY, C.; 
MELLON, M.; MICHELANGELI, D.; MING, D.; MORRIS, R.; RENNO, N.; PIKE, W. T.; STAUFER, U.; STOKER, C.; TAYLOR, P.; WHITEWAY, J.; YOUNG, S.; ZENT, A. Introduction to special section on the Phoenix Mission: Landing Site Characterization Experiments, Mission Overviews, and Expected Science. Journal of Geophysical Research: Planets, v. 113, n. E3, 2008.

SMITH, P. H.; TAMPPARI, L. K.; ARVIDSON, R. E.; BASS, D.; BLANEY, D.; BOYNTON, W. V.; CARSWELL, A.; CATLING, D. C.; CLARK, B. C.; DUCK, T.; DEJONG, E.; FISHER, D.; GOETZ, W.; GUNNLAUGSSON, H. P.; HECHT, M. H.; HIPKIN, V.; HOFFMAN, J.; HVIID, S. F.; KELLER, H. U.; KOUNAVES, S. P.; LANGE, C. F.; LEMMON, M. T.; MADSEN, M. B.; MARKIEWICZ, W. J.; MARSHALL, J.; MCKAY, C. P.; MELLON, M. T.; MING, D. W.; MORRIS, R. V.; PIKE, W. T.; RENNO, N.; STAUFER, U.; STOKER, C.; TAYLOR, P.; WHITEWAY, J. A.; ZENT, A. P. H2O at the Phoenix Landing Site. Science, v. 325, n. 5936, p. 58-61, 2009.

SOARE, R. J.; CONWAY, S. J.; DOHM, J. M. Possible ice-wedge polygons and recent landscape modification by "wet" periglacial processes in and around the Argyre impact basin, Mars. Icarus, v. 233, p. 214-228, 2014.

SPANG, A.; SAW, J. H.; JORGENSEN, S. L.; ZAREMBA-NIEDZWIEDZKA, K.; MARTIJN, J.; LIND, A. E.; VAN EIJK, R.; SCHLEPER, C.; GUY, L.; ETTEMA, T. J. G. Complex archaea that bridge the gap between prokaryotes and eukaryotes. Nature, v. 521, n. 7551, p. 173-179, 2015.

STALEY, J. T.; KONOPKA, A. Measurement of in situ activities of nonphotosynthetic microorganisms in aquatic and terrestrial habitats. Annu Review Microbiology, v. 39, p. 321346, 1985.

STEIN, L. D. The case for cloud computing in genome informatics. Genome Biology, v. 11, n. 5, p. 207, 2010.

STEVEN, B.; BRIGGS, G.; MCKAY, C. P.; POLLARD, W. H.; GREER, C. W.; WHYTE, L. G. Characterization of the microbial diversity in a permafrost sample from the Canadian high Arctic using culture-dependent and culture-independent methods. FEMS microbiology ecology, v. 59, n. 2, p. 513-523, 2007.

STEVEN, B.; LEVEILLE, R.; POLLARD, W. H.; WHYTE, L. G. Microbial ecology and biodiversity in permafrost. Extremophiles, v. 10, n. 4, p. 259-267, 2006.

STEVENSON, A.; BURKHARDT, J.; COCKELL, C. S.; CRAY, J. A.; DIJKSTERHUIS, J.; FOX-POWELL, M.; KEE, T. P.; KMINEK, G.; MCGENITY, T. J.; TIMMIS, K. N. Multiplication of microbes below 0.690 water activity: implications for terrestrial and extraterrestrial life. Environmental Microbiology, v. 17, n. 2, p. 257-277, 2015.

TANAKA, M.; EARL, A. M.; HOWELL, H. A.; PARK, M. J.; EISEN, J. A.; PETERSON, S. N.; BATTISTA, J. R. Analysis of Deinococcus radiodurans's transcriptional response to ionizing radiation and desiccation reveals novel proteins that contribute to extreme radioresistance. Genetics, v. 168, n. 1, p. 21-33, 2004. 
TAS, N.; PRESTAT, E.; MCFARLAND, J. W.; WICKLAND, K. P.; KNIGHT, R.; BERHE, A. A.; JORGENSON, T.; WALDROP, M. P.; JANSSON, J. K. Impact of fire on active layer and permafrost microbial communities and metagenomes in an upland Alaskan boreal forest. ISME Journal, v. 8, n. 9, p. 1904-1919, 2014.

TORSVIK, V.; GOKS $\varnothing$ YR, J.; DAAE, F. L. High diversity in DNA of soil bacteria. Applied and Environmental Microbiology, v. 56, n. 3, p. 782-787, 1990.

TURCATTI, G.; ROMIEU, A.; FEDURCO, M.; TAIRI, A.-P. A new class of cleavable fluorescent nucleotides: synthesis and optimization as reversible terminators for DNA sequencing by synthesis. Nucleic Acids Research, v. 36, n. 4, 2008.

TURNBAUGH, P. J.; LEY, R. E.; HAMADY, M.; FRASER-LIGGETT, C. M.; KNIGHT, R.; GORDON, J. I. The Human Microbiome Project. Nature, v. 449, n. 7164, p. 804-810, 2007.

UNLU, M.; MORGAN, M. E.; MINDEN, J. S. Difference gel electrophoresis: a single gel method for detecting changes in protein extracts. Electrophoresis, v. 18, n. 11, p. 2071-2077, 1997.

UTSUMI, H.; ELKIND, M. M. POTENTIALLY LETHAL DAMAGE QUALITATIVE DIFFERENCES BETWEEN IONIZING AND NON-IONIZING RADIATION AND IMPLICATIONS FOR SINGLE-HIT KILLING. International Journal of Radiation Biology, v. 35, n. 4, p. 373-380, 1979.

VAN DER MAAREL, M. J.; VEEN, A.; WIJBENGA, D. J. Paenibacillus granivorans sp. nov., a new Paenibacillus species which degrades native potato starch granules. Systematic and Applied Microbiology, v. 23, n. 3, p. 344-348, 2000.

VAN DIJK, E. L.; AUGER, H.; JASZCZYSZYN, Y.; THERMES, C. Ten years of next-generation sequencing technology. Trends in Genetics, v. 30, n. 9, p. 418-426, 2014.

VAN EVERDINGEN, R. O. Multi-language glossary of permafrost and related ground-ice terms in Chinese, English, French, German, Icelandic, Italian, Norwegian, Polish, Romanian, Russian, Spanish, and Swedish. International Permafrost Association, Terminology Working Group, 1998.

VENKATESWARAN, K.; KEMPF, M.; CHEN, F.; SATOMI, M.; NICHOLSON, W.; KERN, R. Bacillus nealsonii sp. nov., isolated from a spacecraft-assembly facility, whose spores are gammaradiation resistant. International Journal of Systematic and Evolutionary Microbiology, v. 53, p. 165-172, 2003.

VENTURA, M.; CANCHAYA, C.; TAUCH, A.; CHANDRA, G.; FITZGERALD, G. F.; CHATER, K. F.; VAN SINDEREN, D. Genomics of Actinobacteria: Tracing the evolutionary history of an ancient phylura. Microbiology and Molecular Biology Reviews, v. 71, n. 3, p. 495-548, 2007.

VIEIRA, G.; BOCKHEIM, J.; GUGLIELMIN, M.; BALKS, M.; ABRAMOV, A. A.; BOELHOUWERS, J.; CANNONE, N.; GANZERT, L.; GILICHINSKY, D. A.; GORYACHKIN, S. Thermal state of permafrost and active-layer monitoring in the antarctic: Advances during the international polar year 2007-2009. Permafrost and Periglacial Processes, v. 21, n. 2, p. 182-197, 2010. 
VISHNIVETSKAYA, T.; KATHARIOU, S.; MCGRATH, J.; GILICHINSKY, D.; TIEDJE, J. M. Lowtemperature recovery strategies for the isolation of bacteria from ancient permafrost sediments. Extremophiles, v. 4, n. 3, p. 165-173, 2000.

VISHNIVETSKAYA, T. A.; KATHARIOU, S.; TIEDJE, J. M. The Exiguobacterium genus: biodiversity and biogeography. Extremophiles, v. 13, n. 3, p. 541-555, 2009.

VISHNIVETSKAYA, T. A.; LUCAS, S.; COPELAND, A.; LAPIDUS, A.; DEL RIO, T. G.; DALIN, E.; TICE, H.; BRUCE, D. C.; GOODWIN, L. A.; PITLUCK, S.; SAUNDERS, E.; BRETTIN, T.; DETTER, C.; HAN, C.; LARIMER, F.; LAND, M. L.; HAUSER, L. J.; KYRPIDES, N. C.; OVCHINNIKOVA, G.; KATHARIOU, S.; RAMALEY, R. F.; RODRIGUES, D. F.; HENDRIX, C.; RICHARDSON, P.; TIEDJE, J. M. Complete genome sequence of the thermophilic bacterium Exiguobacterium $\mathrm{sp}$ AT1b. Journal of Bacteriology, v. 193, n. 11, p. 2880-2881, 2011.

WANG, Q.; GARRITY, G. M.; TIEDJE, J. M.; COLE, J. R. Naive Bayesian classifier for rapid assignment of rRNA sequences into the new bacterial taxonomy. Applied and Environmental Microbiology, v. 73, n. 16, p. 5261-5267, 2007.

WARD, D. M.; WELLER, R.; BATESON, M. M. 16S rRNA sequences reveal numerous uncultured microorganisms in a natural community. Nature, v. 345, p. $63-65,1990$.

WEBER, M. H.; MARAHIEL, M. A. Bacterial cold shock responses. Science Progress, v. 86, n. Pt 1-2, p. 9-75, 2003.

WERNER, J. J.; ZHOU, D.; CAPORASO, J. G.; KNIGHT, R.; ANGENENT, L. T. Comparison of Illumina paired-end and single-direction sequencing for microbial $16 \mathrm{~S}$ rRNA gene amplicon surveys. Isme Journal, v. 6, n. 7, p. 1273-1276, 2012.

WILHELM, R. C.; NIEDERBERGER, T. D.; GREER, C.; WHYTE, L. G. Microbial diversity of active layer and permafrost in an acidic wetland from the Canadian High Arctic. Canadian Journal of Microbiology, v. 57, n. 4, p. 303-315, 2011.

WILHELM, R. C.; RADTKE, K. J.; MYKYTCZUK, N. C. S.; GREER, C. W.; WHYTE, L. G. Life at the wedge: the activity and diversity of arctic ice wedge microbial communities. Astrobiology, v. 12, n. 4, p. 347-360, 2012.

WOESE, C. R.; FOX, G. E. Phylogenetic structure of the prokaryotic domain: The primary kingdoms. Proceedings of the National Academy of Sciences, v. 74, n. 11, p. 5088-5090, 1977.

WOESE, C. R.; KANDLER, O.; WHEELIS, M. L. Towards a natural system of organisms: proposal for the domains Archaea, Bacteria, and Eucarya. Proceedings of the National Academy of Sciences, v. 87, n. 12, p. 4576-4579, 1990.

YAMADA, T.; IMACHI, H.; OHASHI, A.; HARADA, H.; HANADA, S.; KAMAGATA, Y.; SEKIGUCHI, Y. Bellilinea caldifistulae gen. nov., sp. nov. and Longilinea arvoryzae gen. nov., sp. nov., strictly anaerobic, filamentous bacteria of the phylum Chloroflexi isolated from methanogenic 
propionate-degrading consortia. International Journal of Systematic and Evolutionary Microbiology, v. 57, n. 10, p. 2299-2306, 2007.

YAMADA, T.; SEKIGUCHI, Y. Cultivation of Uncultured Chloroflexi Subphyla: Significance and Ecophysiology of Formerly Uncultured Chloroflexi 'Subphylum I' with Natural and Biotechnological Relevance. Microbes and Environments, v. 24, n. 3, p. 205-216, 2009.

YERGEAU, E.; HOGUES, H.; WHYTE, L. G.; GREER, C. W. The functional potential of high Arctic permafrost revealed by metagenomic sequencing, qPCR and microarray analyses. ISME Journal, v. 4, n. 9, p. 1206-1214, 2010.

YUE, J. C.; CLAYTON, M. K. A similarity measure based on species proportions. Communications in Statistics-Theory and Methods, v. 34, n. 11, p. 2123-2131, 2005.

ZHANG, T.; HEGINBOTTOM, J. A.; BARRY, R. G.; BROWN, J. Further statistics on the distribution of permafrost and ground ice in the Northern Hemisphere. Polar Geography, v. 24, n. 2, p. 126-131, 2000. 


\section{APÊNDICE A - Classificação de sequências de Axel Heiberg (Filo)}

Número de sequências das amostras de Axel Heiberg pertencentes aos 8 filos mais abundantes e suas respectivas classes, classificadas a partir da ferramenta Classifier (RDP).

\begin{tabular}{|c|c|c|c|c|c|c|c|c|c|}
\hline \multirow{2}{*}{ Filo / Classe } & \multicolumn{9}{|c|}{ Amostras } \\
\hline & a1 & a2 & a3 & m1 & $\mathrm{m} 2$ & m3 & p1 & p2 & p3 \\
\hline Chloroflexi & 4999 & 5510 & 4190 & 3948 & 7598 & 4700 & 7913 & 12203 & 10755 \\
\hline JG37-AG-4 & 1753 & 1421 & 1264 & 2595 & 4453 & 2848 & 5303 & 7424 & 4976 \\
\hline KD4-96 & 850 & 930 & 905 & 686 & 1578 & 777 & 1092 & 2088 & 1921 \\
\hline Ktedonobacteria & 1491 & 2071 & 944 & 118 & 316 & 169 & 492 & 775 & 1195 \\
\hline Gitt-GS-136 & 120 & 196 & 237 & 84 & 332 & 172 & 331 & 807 & 1160 \\
\hline TK10 & 230 & 283 & 443 & 120 & 194 & 246 & 132 & 233 & 329 \\
\hline Chloroflexia & 177 & 247 & 146 & 58 & 133 & 53 & 71 & 117 & 240 \\
\hline P2-11E & 9 & 18 & 26 & 59 & 191 & 81 & 119 & 320 & 381 \\
\hline unclassified & 108 & 82 & 80 & 38 & 103 & 70 & 156 & 200 & 271 \\
\hline S085 & 33 & 43 & 27 & 87 & 130 & 139 & 67 & 90 & 76 \\
\hline JG30-KF-CM66 & 73 & 60 & 26 & 36 & 80 & 83 & 70 & 65 & 84 \\
\hline Thermomicrobia & 106 & 103 & 66 & 22 & 38 & 27 & 26 & 49 & 75 \\
\hline Anaerolineae & 19 & 24 & 9 & 39 & 35 & 26 & 36 & 25 & 27 \\
\hline Caldilineae & 25 & 26 & 14 & 6 & 11 & 8 & 11 & 6 & 13 \\
\hline Elev-1554 & 0 & 2 & 3 & 0 & 4 & 0 & 2 & 4 & 4 \\
\hline SHA-26 & 5 & 4 & 0 & 0 & 0 & 1 & 1 & 0 & 0 \\
\hline Dehalococcoidia & 0 & 0 & 0 & 0 & 0 & 0 & 1 & 0 & 3 \\
\hline Ardenticatenia & 0 & 0 & 0 & 0 & 0 & 0 & 3 & 0 & 0 \\
\hline Actinobacteria & 9773 & 8722 & 6443 & 2260 & 3285 & 2432 & 4998 & 5488 & 5420 \\
\hline Actinobacteria & 7562 & 6664 & 4319 & 776 & 988 & 775 & 2087 & 1956 & 2188 \\
\hline Thermoleophilia & 1240 & 1230 & 1163 & 801 & 1476 & 948 & 2213 & 2748 & 2213 \\
\hline unclassified & 485 & 413 & 403 & 370 & 463 & 370 & 333 & 393 & 544 \\
\hline MB-A2-108 & 228 & 174 & 227 & 187 & 191 & 168 & 263 & 248 & 325 \\
\hline Acidimicrobiia & 244 & 227 & 324 & 125 & 164 & 163 & 98 & 136 & 142 \\
\hline TakashiAC-B11 & 13 & 13 & 7 & 1 & 1 & 2 & 4 & 7 & 8 \\
\hline FFCH16263 & 0 & 0 & 0 & 0 & 2 & 6 & 0 & 0 & 0 \\
\hline Rubrobacteria & 1 & 1 & 0 & 0 & 0 & 0 & 0 & 0 & 0 \\
\hline Proteobacteria & 5412 & 5707 & 7388 & 2070 & 3402 & 2067 & 2020 & 2871 & 3963 \\
\hline Alphaproteobacteria & 4271 & 4499 & 5609 & 1681 & 2555 & 1477 & 1036 & 1336 & 806 \\
\hline Betaproteobacteria & 85 & 120 & 316 & 152 & 366 & 256 & 535 & 987 & 2534 \\
\hline Gammaproteobacteria & 547 & 691 & 811 & 85 & 204 & 133 & 218 & 305 & 379 \\
\hline Deltaproteobacteria & 441 & 335 & 550 & 124 & 238 & 170 & 201 & 229 & 188 \\
\hline unclassified & 68 & 62 & 99 & 28 & 34 & 19 & 24 & 14 & 56 \\
\hline TA18 & 0 & 0 & 3 & 0 & 5 & 12 & 3 & 0 & 0 \\
\hline Epsilonproteobacteria & 0 & 0 & 0 & 0 & 0 & 0 & 3 & 0 & 0 \\
\hline
\end{tabular}

(Continua) 


\begin{tabular}{|c|c|c|c|c|c|c|c|c|c|}
\hline Acidobacteria & 5385 & 6611 & 4545 & 1278 & 2112 & 1396 & 819 & 1068 & 823 \\
\hline Acidobacteria & 5255 & 6464 & 4412 & 896 & 1221 & 950 & 579 & 686 & 501 \\
\hline Holophagae & 129 & 144 & 130 & 378 & 885 & 441 & 238 & 378 & 321 \\
\hline Subgroup_22 & 0 & 1 & 0 & 1 & 1 & 3 & 2 & 2 & 0 \\
\hline unclassified & 1 & 2 & 3 & 3 & 5 & 2 & 0 & 2 & 1 \\
\hline Gemmatimonadetes & 586 & 593 & 612 & 1843 & 4036 & 1801 & 2790 & 2904 & 1730 \\
\hline Gemmatimonadetes & 586 & 593 & 612 & 1843 & 4036 & 1801 & 2790 & 2904 & 1730 \\
\hline Planctomycetes & 1846 & 1710 & 3543 & 1070 & 1711 & 1196 & 519 & 679 & 580 \\
\hline Phycisphaerae & 782 & 700 & 1708 & 783 & 1252 & 768 & 286 & 426 & 321 \\
\hline Planctomycetacia & 1060 & 997 & 1829 & 280 & 433 & 412 & 226 & 248 & 247 \\
\hline vadinHA49 & 3 & 3 & 1 & 3 & 22 & 10 & 7 & 2 & 6 \\
\hline unclassified & 1 & 5 & 5 & 4 & 3 & 5 & 0 & 3 & 5 \\
\hline OM190 & 0 & 3 & 0 & 0 & 1 & 1 & 0 & 0 & 1 \\
\hline BD7-11 & 0 & 2 & 0 & 0 & 0 & 0 & 0 & 0 & 0 \\
\hline Verrucomicrobia & 475 & 704 & 1807 & 1272 & 2315 & 1821 & 897 & 910 & 1186 \\
\hline Spartobacteria & 356 & 516 & 723 & 1088 & 1877 & 1590 & 665 & 626 & 884 \\
\hline OPB35_soil_group & 21 & 33 & 29 & 74 & 201 & 103 & 160 & 180 & 198 \\
\hline Verrucomicrobia_Incertae_S & 16 & 25 & 849 & 3 & 16 & 2 & 13 & 8 & 16 \\
\hline Opitutae & 24 & 50 & 34 & 60 & 150 & 69 & 29 & 58 & 55 \\
\hline unclassified & 45 & 69 & 166 & 22 & 39 & 31 & 29 & 28 & 4 \\
\hline Verrucomicrobiae & 8 & 6 & 3 & 16 & 27 & 21 & 1 & 10 & 27 \\
\hline S-BQ2-57_soil_group & 5 & 5 & 2 & 9 & 4 & 5 & 0 & 0 & 2 \\
\hline UA11 & 0 & 0 & 1 & 0 & 1 & 0 & 0 & 0 & 0 \\
\hline Bacteroidetes & 977 & 1803 & 1646 & 305 & 1147 & 490 & 786 & 1171 & 2957 \\
\hline Sphingobacteriia & 916 & 1749 & 1578 & 286 & 1097 & 468 & 650 & 974 & 2828 \\
\hline Flavobacteriia & 15 & 14 & 12 & 11 & 25 & 3 & 109 & 152 & 53 \\
\hline Cytophagia & 37 & 27 & 40 & 6 & 5 & 6 & 7 & 8 & 18 \\
\hline unclassified & 8 & 12 & 15 & 2 & 20 & 13 & 6 & 3 & 18 \\
\hline WCHB1-32 & 1 & 0 & 0 & 0 & 0 & 0 & 3 & 13 & 28 \\
\hline Bacteroidia & 0 & 0 & 0 & 0 & 0 & 0 & 11 & 14 & 5 \\
\hline BSV13 & 0 & 1 & 0 & 0 & 0 & 0 & 0 & 7 & 4 \\
\hline vadinHA17 & 0 & 0 & 0 & 0 & 0 & 0 & 0 & 0 & 3 \\
\hline BD2-2 & 0 & 0 & 1 & 0 & 0 & 0 & 0 & 0 & 0 \\
\hline Candidate_division_TM7 & 1232 & 1588 & 1573 & 208 & 494 & 224 & 351 & 536 & 939 \\
\hline unclassified & 1232 & 1588 & 1573 & 208 & 494 & 224 & 351 & 536 & 939 \\
\hline Armatimonadetes & 1559 & 1418 & 1464 & 180 & 218 & 197 & 186 & 182 & 189 \\
\hline Armatimonadia & 1451 & 1359 & 1353 & 13 & 29 & 16 & 64 & 56 & 60 \\
\hline Chthonomonadetes & 86 & 28 & 59 & 129 & 129 & 136 & 89 & 92 & 101 \\
\hline unclassified & 22 & 31 & 52 & 38 & 60 & 45 & 33 & 34 & 28 \\
\hline
\end{tabular}

(Continua) 


\begin{tabular}{lccccccccc} 
Candidate_division_OD1 & 134 & 116 & 124 & 531 & 1094 & 370 & 441 & 495 & 1467 \\
unclassified & 134 & 116 & 124 & 531 & 1094 & 370 & 441 & 495 & 1467 \\
WD272 & 608 & 375 & 557 & 117 & 130 & 95 & 51 & 48 & 26 \\
unclassified & 608 & 375 & 557 & 117 & 130 & 95 & 51 & 48 & 26 \\
Cyanobacteria & 321 & 447 & 468 & 11 & 30 & 13 & 60 & 110 & 10 \\
Cyanobacteria & 212 & 318 & 330 & 3 & 13 & 0 & 53 & 73 & 1 \\
ML635J-21 & 6 & 6 & 16 & 0 & 1 & 6 & 0 & 4 & 3 \\
Melainabacteria & 5 & 6 & 12 & 8 & 15 & 7 & 2 & 13 & 6 \\
unclassified & 98 & 117 & 110 & 0 & 1 & 0 & 5 & 20 & 0 \\
WCHB1-60 & 209 & 234 & 194 & 17 & 57 & 35 & 43 & 74 & 87 \\
unclassified & 209 & 234 & 194 & 17 & 57 & 35 & 43 & 74 & 87 \\
Firmicutes & 13 & 13 & 10 & 30 & 42 & 38 & 160 & 256 & 269 \\
Bacilli & 7 & 4 & 3 & 4 & 16 & 1 & 49 & 79 & 27 \\
Clostridia & 4 & 3 & 0 & 26 & 25 & 35 & 101 & 171 & 232 \\
Erysipelotrichia & 2 & 6 & 2 & 0 & 0 & 0 & 0 & 0 & 0 \\
Negativicutes & 0 & 0 & 0 & 0 & 0 & 2 & 7 & 6 & 6 \\
unclassified & 0 & 0 & 5 & 0 & 1 & 0 & 3 & 0 & 4 \\
\hline
\end{tabular}




\section{APÊNDICE B - Classificação de sequências de Axel Heiberg (Família)}

Número de sequências das amostras de Axel Heiberg classificadas nas 100 famílias mais abundantes, segundo a ferramenta Classifier (RDP). Cutoff utilizado para família foi 0,10.

\begin{tabular}{|c|c|c|c|c|c|c|c|c|c|}
\hline \multirow{2}{*}{ Famílias } & \multicolumn{9}{|c|}{ Amostras } \\
\hline & a1 & a2 & a3 & m1 & m2 & m3 & p1 & p2 & p3 \\
\hline 0319-6G20 & 131 & 86 & 102 & 6 & 12 & 12 & 31 & 23 & 42 \\
\hline 0319-6M6 & 20 & 28 & 21 & 6 & 35 & 11 & 23 & 60 & 23 \\
\hline 1174-901-12 & 49 & 71 & 47 & 16 & 15 & 8 & 24 & 14 & 5 \\
\hline $1921-3$ & 34 & 26 & 8 & 2 & 2 & 6 & 6 & 5 & 16 \\
\hline $480-2$ & 62 & 72 & 58 & 51 & 98 & 58 & 103 & 160 & 92 \\
\hline Acetobacteraceae & 1781 & 1849 & 2777 & 16 & 20 & 17 & 63 & 58 & 61 \\
\hline Acidimicrobiaceae & 53 & 64 & 153 & 8 & 23 & 26 & 20 & 17 & 42 \\
\hline Acidimicrobiales_Inc._S. & 7 & 4 & 14 & 1 & 0 & 1 & 0 & 0 & 0 \\
\hline Acidobacteriaceae_(S_1) & 4712 & 6133 & 3587 & 143 & 277 & 212 & 227 & 330 & 252 \\
\hline Acidothermaceae & 179 & 114 & 69 & 48 & 62 & 39 & 57 & 71 & 31 \\
\hline Alicyclobacillaceae & 4 & 2 & 2 & 1 & 9 & 0 & 30 & 66 & 23 \\
\hline alphal_cluster & 23 & 13 & 72 & 1 & 2 & 5 & 2 & 1 & 2 \\
\hline Anaerolineaceae & 19 & 24 & 9 & 39 & 35 & 26 & 36 & 25 & 27 \\
\hline Bacteriovoracaceae & 0 & 1 & 0 & 2 & 0 & 0 & 9 & 9 & 22 \\
\hline Bdellovibrionaceae & 50 & 48 & 42 & 11 & 11 & 12 & 19 & 6 & 17 \\
\hline Beijerinckiaceae & 31 & 33 & 94 & 0 & 3 & 0 & 7 & 12 & 11 \\
\hline Bradyrhizobiaceae & 38 & 57 & 139 & 48 & 68 & 48 & 17 & 68 & 41 \\
\hline Caldilineaceae & 25 & 26 & 14 & 6 & 11 & 8 & 11 & 6 & 13 \\
\hline Caulobacteraceae & 703 & 373 & 278 & 610 & 705 & 245 & 326 & 324 & 102 \\
\hline Chitinophagaceae & 772 & 1567 & 1241 & 201 & 855 & 360 & 278 & 571 & 814 \\
\hline Chromatiaceae & 0 & 0 & 0 & 1 & 2 & 3 & 17 & 32 & 18 \\
\hline Chthoniobacteraceae & 71 & 106 & 143 & 14 & 41 & 17 & 30 & 22 & 33 \\
\hline Chthonomonadaceae & 62 & 19 & 51 & 73 & 56 & 79 & 77 & 71 & 86 \\
\hline Clostridiaceae_1 & 4 & 2 & 0 & 23 & 22 & 30 & 56 & 63 & 141 \\
\hline Comamonadaceae & 12 & 20 & 135 & 1 & 4 & 9 & 21 & 15 & 28 \\
\hline Coxiellaceae & 35 & 70 & 97 & 31 & 29 & 49 & 19 & 19 & 19 \\
\hline Cystobacteraceae & 20 & 15 & 36 & 6 & 18 & 9 & 14 & 9 & 29 \\
\hline Cytophagaceae & 35 & 26 & 34 & 6 & 5 & 6 & 6 & 8 & 18 \\
\hline DA101_soil_group & 248 & 378 & 493 & 1026 & 1771 & 1522 & 605 & 587 & 832 \\
\hline DA111 & 204 & 223 & 244 & 59 & 181 & 192 & 107 & 149 & 87 \\
\hline Ectothiorhodospiraceae & 4 & 5 & 11 & 1 & 3 & 3 & 2 & 14 & 186 \\
\hline Elev-16S-1332 & 3 & 5 & 4 & 2 & 6 & 2 & 4 & 3 & 11 \\
\hline env.OPS_17 & 23 & 29 & 38 & 15 & 49 & 24 & 64 & 97 & 628 \\
\hline Familyl & 209 & 314 & 328 & 3 & 10 & 0 & 53 & 73 & 1 \\
\hline Fibrobacteraceae & 2 & 1 & 0 & 4 & 13 & 3 & 7 & 5 & 6 \\
\hline Flavobacteriaceae & 11 & 9 & 9 & 11 & 25 & 3 & 106 & 152 & 53 \\
\hline Frankiaceae & 593 & 558 & 326 & 92 & 104 & 57 & 218 & 234 & 172 \\
\hline FukuN18_freshwater_gr. & 1 & 3 & 5 & 2 & 7 & 5 & 4 & 0 & 9 \\
\hline G12-WMSP1 & 59 & 70 & 23 & 1 & 1 & 4 & 1 & 4 & 11 \\
\hline Gaiellaceae & 303 & 214 & 235 & 173 & 276 & 248 & 519 & 574 & 353 \\
\hline Gallionellaceae & 0 & 0 & 3 & 5 & 8 & 12 & 273 & 538 & 1945 \\
\hline Gemmatimonadaceae & 584 & 592 & 610 & 1841 & 4024 & 1795 & 2790 & 2894 & 1728 \\
\hline Geodermatophilaceae & 470 & 337 & 184 & 4 & 7 & 4 & 53 & 26 & 28 \\
\hline Haliangiaceae & 40 & 58 & 106 & 49 & 130 & 75 & 48 & 106 & 32 \\
\hline Holophagaceae & 13 & 5 & 6 & 0 & 3 & 2 & 1 & 0 & 3 \\
\hline Holosporaceae & 9 & 12 & 13 & 0 & 3 & 3 & 2 & 0 & 0 \\
\hline
\end{tabular}

(Continua) 
HSB_OF53-F07

Hydrogenophilaceae

Hyphomicrobiaceae

lamiaceae

Intrasporangiaceae

JG30a-KF-32

KD3-93

KF-JG30-B3

Kineosporiaceae

Legionellaceae

Microbacteriaceae

Micrococcaceae

Micromonosporaceae

Nakamurellaceae

Neisseriaceae

Nitrosomonadaceae

Nitrospiraceae

Nocardioidaceae

Opitutaceae

Oxalobacteraceae

Parachlamydiaceae

Patulibacteraceae

Peptococcaceae

PHOS-HE51

Phycisphaeraceae

Planctomycetaceae

Polyangiaceae

Porphyromonadaceae

Propionibacteriaceae

Pseudomonadaceae

Pseudonocardiaceae

RB41

Rhizobiaceae

Rhizobiales_Inc._Sedis

Rhodobiaceae

Rickettsiales_Inc._Sedis

Roseiflexaceae

Ruminococcaceae

SM2D12

Solirubrobacteraceae

Sphaerobacteraceae

Sphingobacteriaceae

Sphingomonadaceae

Streptomycetaceae

TM146

Unknown_Family

Unknown_Family

Unknown_Family

Unknown_Family

Verrucomicrobiaceae

Xanthobacteraceae

Xanthomonadaceae

Xiphinematobacteraceae

YNPFFP1

$\begin{array}{lll}2 & 3 & 13\end{array}$

$\begin{array}{lll}54 & 47 & 127\end{array}$

$26 \quad 14 \quad 19$

$599 \quad 552 \quad 216$

596

1000

261

0

3
$160 \quad 104$

$10 \quad 10$

$1102 \quad 1396$

69

64

1334

0

0

$\begin{array}{lll}0 & 0 & 2\end{array}$

$306 \quad 335 \quad 171$

$24 \quad 49$

$16 \quad 28$

$9 \quad 17$

31

0

3

1058

1058

10

$$
228
$$$$
\begin{array}{r}
259 \\
16
\end{array}
$$$$
12
$$

89

28

40

92

0

5

30

14

112

966

5

$7 \quad 12$

$448 \quad 247$

$16 \quad 25$

$16 \quad 10$

$0 \quad 1$

86

$64 \quad 78$

$336 \quad 450$

49

$133 \quad 133$$$
1161
$$$$
12
$$$$
699
$$$$
849
$$$$
\begin{array}{r}
849 \\
5
\end{array}
$$

$$
\begin{aligned}
& 5 \\
& 0
\end{aligned}
$$$$
2
$$$$
78
$$$$
428
$$$$
38
$$

108

$\begin{array}{rr}0 & 4 \\ 11 & 14 \\ 43 & 47 \\ 48 & 36 \\ 52 & 116 \\ 32 & 150 \\ 5 & 23 \\ 108 & 103 \\ 34 & 49 \\ 3 & 0 \\ 22 & 35 \\ 113 & 116 \\ 16 & 25 \\ 34 & 39 \\ 0 & 4 \\ 10 & 38 \\ 11 & 11 \\ 55 & 115 \\ 60 & 148 \\ 3 & 5 \\ 13 & 26 \\ 26 & 53 \\ 0 & 2 \\ 2 & 6 \\ 7 & 12 \\ 278 & 433 \\ 13 & 19 \\ 35\end{array}$

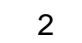

6

$\begin{array}{rr}0 & 4 \\ 144 & 211 \\ 36 & 26 \\ 22 & 30 \\ 633 & 1050 \\ 393 & 582 \\ 13 & 20 \\ 5 & 10 \\ 40 & 49 \\ 9 & 6 \\ 174 & 106\end{array}$

123

127

126

12

27

1

13

10

59

67

2

27

25

5

12

4
412

14$$
\begin{aligned}
& 0 \\
& 3
\end{aligned}
$$$$
2
$$$$
6
$$$$
\begin{array}{r}
6 \\
95
\end{array}
$$$$
0
$$$$
210
$$$$
54
$$$$
2
$$$$
\begin{array}{r}
53 \\
0
\end{array}
$$$$
0
$$$$
17
$$$$
0
$$$$
52
$$

\begin{tabular}{|c|c|c|}
\hline 78 & 144 & 211 \\
\hline 29 & 36 & 26 \\
\hline 21 & 22 & 30 \\
\hline 656 & 633 & 1050 \\
\hline 162 & 393 & 582 \\
\hline 2 & 13 & 20 \\
\hline 2 & 5 & 10 \\
\hline 50 & 40 & 49 \\
\hline 2 & 9 & 6 \\
\hline 122 & 174 & 106 \\
\hline 159 & 123 & 127 \\
\hline 40 & 31 & 32 \\
\hline 86 & 91 & 69 \\
\hline 24 & 36 & 43 \\
\hline 2 & 8 & 15 \\
\hline 2 & 1 & 16 \\
\hline 91 & 98 & 128 \\
\hline 29 & 54 & 55 \\
\hline 0 & 12 & 13 \\
\hline 9 & 8 & 13 \\
\hline 45 & 46 & 62 \\
\hline 31 & 94 & 66 \\
\hline 6 & 21 & 70 \\
\hline 6 & 0 & 9 \\
\hline 226 & 248 & 247 \\
\hline 33 & 33 & 4 \\
\hline 8 & 14 & 5 \\
\hline 28 & 60 & 38 \\
\hline 70 & 49 & 15 \\
\hline 33 & 25 & 10 \\
\hline 57 & 106 & 56 \\
\hline 4 & 0 & 0 \\
\hline 74 & 74 & 60 \\
\hline 71 & 65 & 25 \\
\hline 3 & 0 & 3 \\
\hline 70 & 106 & 238 \\
\hline 12 & 9 & 22 \\
\hline 3 & 0 & 0 \\
\hline 25 & 37 & 20 \\
\hline 0 & 2 & 2 \\
\hline 278 & 254 & 1251 \\
\hline 122 & 181 & 175 \\
\hline 2 & 5 & 2 \\
\hline 9 & 37 & 46 \\
\hline 216 & 179 & 123 \\
\hline 13 & 8 & 16 \\
\hline 14 & 23 & 9 \\
\hline 1 & 0 & 2 \\
\hline 1 & 10 & 24 \\
\hline 140 & 266 & 154 \\
\hline 45 & 113 & 20 \\
\hline 6 & 7 & 5 \\
\hline 131 & 200 & 123 \\
\hline
\end{tabular}$$
217
$$ 


\section{APÊNDICE C - Classificação de sequências de Axel Heiberg (Gênero)}

Número de sequências das amostras de Axel Heiberg classificadas nos 100 gêneros mais abundantes, classificados segundo a ferramenta Classifier (RDP). Cutoff utilizado para gênero foi 0,03.

\begin{tabular}{|c|c|c|c|c|c|c|c|c|c|}
\hline \multirow{2}{*}{ Gêneros } & \multicolumn{9}{|c|}{ Amostras } \\
\hline & a1 & a2 & a3 & m1 & m2 & m3 & p1 & p2 & p3 \\
\hline Acidicaldus & 11 & 13 & 21 & 1 & 3 & 6 & 2 & 2 & 0 \\
\hline Acidiferrobacter & 2 & 5 & 11 & 1 & 3 & 3 & 2 & 14 & 183 \\
\hline Acidiphilium & 212 & 222 & 309 & 1 & 0 & 0 & 14 & 2 & 3 \\
\hline Acidisoma & 76 & 119 & 151 & 0 & 0 & 0 & 2 & 3 & 0 \\
\hline Acidobacterium & 523 & 461 & 539 & 6 & 4 & 11 & 8 & 34 & 24 \\
\hline Acidothermus & 179 & 114 & 69 & 48 & 62 & 39 & 57 & 71 & 31 \\
\hline Actinoplanes & 12 & 7 & 25 & 0 & 0 & 0 & 4 & 0 & 0 \\
\hline Aestuariimicrobium & 3 & 0 & 0 & 0 & 0 & 0 & 6 & 18 & 20 \\
\hline Amnibacterium & 460 & 489 & 301 & 2 & 5 & 1 & 27 & 50 & 20 \\
\hline Anaeromyxobacter & 10 & 8 & 22 & 5 & 3 & 9 & 7 & 7 & 19 \\
\hline Angustibacter & 50 & 34 & 22 & 1 & 0 & 2 & 19 & 7 & 12 \\
\hline Aquicella & 34 & 67 & 95 & 28 & 27 & 46 & 19 & 19 & 17 \\
\hline Aquincola & 9 & 17 & 93 & 0 & 0 & 5 & 7 & 0 & 0 \\
\hline Arthrobacter & 63 & 76 & 62 & 109 & 108 & 123 & 153 & 116 & 121 \\
\hline Asticcacaulis & 7 & 3 & 9 & 5 & 5 & 0 & 0 & 1 & 0 \\
\hline Bacteriovorax & 0 & 1 & 0 & 0 & 0 & 0 & 9 & 3 & 22 \\
\hline Bauldia & 14 & 19 & 19 & 43 & 169 & 70 & 22 & 22 & 20 \\
\hline Bdellovibrio & 50 & 48 & 42 & 9 & 11 & 10 & 16 & 6 & 17 \\
\hline Blastocatella & 16 & 10 & 5 & 52 & 66 & 34 & 14 & 23 & 9 \\
\hline Brevundimonas & 16 & 0 & 6 & 5 & 7 & 0 & 66 & 46 & 4 \\
\hline Bryobacter & 207 & 108 & 261 & 344 & 295 & 238 & 81 & 64 & 56 \\
\hline Bryocella & 5 & 12 & 15 & 0 & 0 & 0 & 0 & 0 & 0 \\
\hline Candidatus_Koribacter & 1 & 1 & 0 & 12 & 16 & 7 & 0 & 2 & 0 \\
\hline Candidatus_Methylacidiphilum & 16 & 25 & 849 & 3 & 16 & 2 & 13 & 8 & 16 \\
\hline Candidatus_Nitrotoga & 0 & 0 & 2 & 0 & 1 & 6 & 8 & 17 & 25 \\
\hline Candidatus_Nostocoida & 21 & 28 & 40 & 7 & 12 & 12 & 6 & 5 & 3 \\
\hline Candidatus_Odyssella & 39 & 35 & 46 & 0 & 0 & 0 & 3 & 0 & 0 \\
\hline Candidatus_Protochlamydia & 4 & 7 & 7 & 4 & 12 & 10 & 0 & 3 & 0 \\
\hline Candidatus_Solibacter & 241 & 139 & 438 & 171 & 153 & 215 & 134 & 113 & 67 \\
\hline Candidatus_Xiphinematobacter & 4 & 9 & 38 & 4 & 3 & 10 & 6 & 7 & 5 \\
\hline Chthoniobacter & 71 & 106 & 143 & 14 & 41 & 17 & 30 & 22 & 33 \\
\hline Chthonomonas & 62 & 19 & 51 & 73 & 56 & 79 & 77 & 71 & 86 \\
\hline CL500-29_marine_group & 53 & 63 & 153 & 8 & 23 & 26 & 18 & 16 & 41 \\
\hline Clostridium_s._stricto_13 & 2 & 0 & 0 & 23 & 18 & 27 & 30 & 44 & 80 \\
\hline Clostridium_s._stricto_9 & 0 & 2 & 0 & 0 & 0 & 2 & 14 & 9 & 36 \\
\hline Crossiella & 144 & 70 & 23 & 0 & 0 & 0 & 7 & 1 & 2 \\
\hline Cytophaga & 29 & 20 & 22 & 0 & 0 & 0 & 2 & 3 & 2 \\
\hline Desulfosporosinus & 0 & 1 & 0 & 0 & 2 & 5 & 31 & 94 & 64 \\
\hline Devosia & 40 & 36 & 117 & 19 & 23 & 20 & 24 & 25 & 7 \\
\hline Edaphobacter & 109 & 131 & 88 & 0 & 0 & 0 & 4 & 7 & 2 \\
\hline Flavobacterium & 8 & 7 & 6 & 10 & 25 & 3 & 102 & 147 & 49 \\
\hline Frankia & 68 & 36 & 26 & 1 & 0 & 0 & 4 & 3 & 3 \\
\hline Frondihabitans & 27 & 52 & 40 & 2 & 2 & 0 & 2 & 6 & 15 \\
\hline Gaiella & 303 & 214 & 235 & 173 & 276 & 248 & 519 & 574 & 353 \\
\hline Gallionella & 0 & 0 & 0 & 0 & 0 & 0 & 24 & 25 & 97 \\
\hline Gemmata & 59 & 59 & 110 & 33 & 65 & 58 & 34 & 21 & 29 \\
\hline
\end{tabular}




\begin{tabular}{|c|c|c|c|c|c|c|c|c|c|}
\hline Gemmatimonas & 107 & 99 & 99 & 129 & 223 & 136 & 183 & 206 & 117 \\
\hline Granulicella & 3822 & 5224 & 2688 & 62 & 123 & 45 & 152 & 234 & 117 \\
\hline Haliangium & 40 & 58 & 106 & 49 & 130 & 75 & 48 & 106 & 32 \\
\hline lamia & 26 & 14 & 19 & 48 & 36 & 40 & 21 & 22 & 30 \\
\hline Isosphaera & 11 & 17 & 41 & 9 & 5 & 11 & 1 & 7 & 3 \\
\hline Jatrophihabitans & 525 & 520 & 300 & 91 & 104 & 57 & 214 & 231 & 169 \\
\hline Kineosporia & 34 & 32 & 24 & 26 & 34 & 23 & 23 & 25 & 29 \\
\hline Leeia & 0 & 0 & 0 & 0 & 4 & 1 & 24 & 34 & 43 \\
\hline Legionella & 10 & 10 & 12 & 3 & 0 & 1 & 2 & 9 & 6 \\
\hline Lysinimonas & 510 & 736 & 613 & 17 & 24 & 14 & 82 & 102 & 66 \\
\hline Marmoricola & 143 & 164 & 47 & 28 & 67 & 42 & 60 & 66 & 86 \\
\hline Microlunatus & 153 & 226 & 101 & 7 & 8 & 2 & 17 & 29 & 15 \\
\hline Modestobacter & 467 & 336 & 184 & 4 & 7 & 4 & 53 & 26 & 28 \\
\hline Mucilaginibacter & 107 & 129 & 287 & 50 & 111 & 44 & 262 & 235 & 1234 \\
\hline Nakamurella & 1334 & 1045 & 356 & 34 & 39 & 27 & 86 & 91 & 69 \\
\hline Nitrosococcus & 0 & 0 & 0 & 1 & 2 & 3 & 17 & 30 & 18 \\
\hline Nitrospira & 0 & 0 & 2 & 11 & 11 & 10 & 2 & 1 & 16 \\
\hline Nocardioides & 149 & 145 & 117 & 26 & 46 & 17 & 26 & 29 & 41 \\
\hline Nostoc & 202 & 300 & 311 & 3 & 10 & 0 & 52 & 69 & 1 \\
\hline Novosphingobium & 8 & 10 & 27 & 1 & 0 & 0 & 2 & 3 & 0 \\
\hline Opitutus & 22 & 47 & 31 & 60 & 141 & 67 & 29 & 54 & 53 \\
\hline Oryzihumus & 135 & 110 & 30 & 29 & 44 & 23 & 403 & 422 & 713 \\
\hline Patulibacter & 31 & 35 & 31 & 26 & 53 & 25 & 45 & 46 & 62 \\
\hline Pedosphaera & 0 & 1 & 0 & 3 & 9 & 14 & 1 & 0 & 2 \\
\hline Phenylobacterium & 194 & 110 & 71 & 592 & 674 & 242 & 251 & 270 & 93 \\
\hline Phycisphaera & 0 & 0 & 0 & 7 & 11 & 4 & 6 & 0 & 9 \\
\hline Pir4_lineage & 10 & 12 & 13 & 30 & 46 & 21 & 9 & 21 & 14 \\
\hline Pirellula & 1 & 3 & 0 & 3 & 8 & 15 & 1 & 0 & 6 \\
\hline Planctomyces & 34 & 22 & 62 & 58 & 106 & 185 & 25 & 35 & 60 \\
\hline possible_genus_04 & 2 & 1 & 0 & 4 & 13 & 3 & 7 & 5 & 6 \\
\hline Pseudolabrys & 63 & 78 & 78 & 284 & 475 & 307 & 134 & 260 & 145 \\
\hline Pseudomonas & 7 & 4 & 14 & 5 & 13 & 2 & 69 & 48 & 11 \\
\hline Pseudonocardia & 114 & 80 & 24 & 2 & 9 & 6 & 24 & 23 & 8 \\
\hline Rhizobium & 5 & 2 & 32 & 0 & 0 & 0 & 0 & 0 & 0 \\
\hline Rhizomicrobium & 75 & 46 & 156 & 235 & 293 & 140 & 52 & 52 & 40 \\
\hline Rhodanobacter & 208 & 258 & 230 & 0 & 16 & 9 & 19 & 48 & 7 \\
\hline Rhodobium & 28 & 32 & 55 & 63 & 71 & 53 & 71 & 65 & 25 \\
\hline Rhodoplanes & 6 & 11 & 9 & 21 & 17 & 23 & 5 & 4 & 8 \\
\hline Roseiflexus & 92 & 184 & 123 & 55 & 128 & 53 & 70 & 106 & 238 \\
\hline Sandarakinorhabdus & 7 & 16 & 16 & 0 & 0 & 0 & 0 & 2 & 0 \\
\hline Sideroxydans & 0 & 0 & 1 & 4 & 5 & 5 & 223 & 474 & 1756 \\
\hline Singulisphaera & 452 & 429 & 928 & 6 & 17 & 13 & 26 & 39 & 16 \\
\hline Solirubrobacter & 30 & 20 & 12 & 20 & 31 & 17 & 25 & 37 & 20 \\
\hline Sorangium & 100 & 50 & 93 & 9 & 16 & 12 & 23 & 30 & 4 \\
\hline Sphingomonas & 719 & 931 & 767 & 27 & 69 & 83 & 71 & 82 & 112 \\
\hline Sporocytophaga & 1 & 4 & 6 & 5 & 5 & 2 & 3 & 5 & 10 \\
\hline Stenotrophomonas & 0 & 1 & 0 & 0 & 8 & 0 & 5 & 22 & 0 \\
\hline Streptacidiphilus & 5 & 11 & 62 & 0 & 0 & 0 & 2 & 5 & 2 \\
\hline Sulfuricella & 1 & 0 & 1 & 0 & 0 & 1 & 2 & 4 & 20 \\
\hline Telmatobacter & 60 & 78 & 87 & 8 & 11 & 12 & 10 & 7 & 22 \\
\hline Terriglobus & 49 & 42 & 17 & 0 & 0 & 0 & 1 & 6 & 0 \\
\hline Thiobacillus & 1 & 3 & 10 & 9 & 12 & 21 & 76 & 139 & 190 \\
\hline Tumebacillus & 4 & 2 & 2 & 1 & 9 & 0 & 30 & 66 & 23 \\
\hline Verrucomicrobium & 0 & 2 & 0 & 13 & 17 & 8 & 0 & 0 & 7 \\
\hline
\end{tabular}

